NATL INST OF STANDARDS \& TECH R.I.C.

NBSIR 86-3049

A11102516756

McHenry Harry QC100.U56 NO.86-3049 1986 V19 C.1 NBS-P

\title{
EXAMINATION OF A PRESSURE VESSEL THAT RUPTURED AT THE CHICAGO REFINERY OF THE UNION OIL COMPANY ON JULY 23, 1984
}

Harry I. McHenry

T. Robert Shives

David T. Read

J. David McColskey

Charles H. Brady

Patrick T. Purtscher

National Bureau of Standards

U.S. Department of Commerce

Boulder, Colorado 80303

March 1986

Sponsored by

Occupational Safety and Health Administration

U.S. Department of Labor

Washington, DC 20210

$Q C$

100

.456

$86-3049$ 



\section{EXAMINATION OF A PRESSURE VESSEL THAT RUPTURED AT THE CHICAGO REFINERY OF THE UNION OIL COMPANY ON JULY 23, 1984}

Harry I. McHenry

T. Robert Shives

David T. Read

J. David McColskey

Charles H. Brady

Patrick T. Purtscher

Fracture and Deformation Division

Institute for Materials Science and Engineering National Bureau of Standards

Boulder, Colorado 80303

March 1986

Sponsored by

Occupational Safety and Health Administration

U.S. Department of Labor

Washington, DC 20210

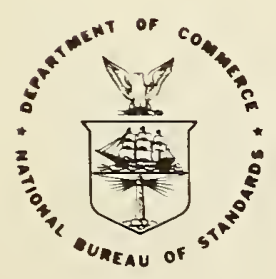

U.S. DEPARTMENT OF COMMERCE, Malcolm Baldrige, Secretary 

FOREWORD

This failure investigation was conducted by an interdisciplinary team of NBS personnel. Responsibilities for the major areas of investigation were as follows:
H. I. McHenry
Principal Investigator
T. R. Shives
Gai thersburg Coord inator
U. Bertocci
Corrosion
C. H. Brady
Metallography
J. D. McColskey
Testing
R. Mar inenko
Microchemical Analysis
J. A. Norris
Chemical Analysis
P. T. Purt scher
Fractography
D. T. Read
Fracture Mechanics
R. E. Schramm
Inspection
T. A. Siewert
We ld ing

Many others made important contributions to this investigation, including E. Escalante, R. J. Fields, D. E. Harne, M. J. Kaufman, R. D. Kriz, N. Sanchez, B. A. Stevenson, A. C. Van Orden, D. P. Vigliotti and $\mathrm{R}$. O. Voth. The field investigation conducted in the week following the incident was performed by B. W. Christ and R. Shull.

The authors acknow ledge the critical reviews provided by E. Passaglia, E. N. Pugh, and M. B. Kasen.

The investigation was conducted under the direction of $\mathrm{K}$. J. Yotz, the Project Officer for OSHA, and R. P. Reed, the Project Officer for NBS.

NOTE: An initial investigation was performed by a private company of eng ineering consultants. This company is referred to by name in the text of this report in order to state clearly the relationship between the initial investigation and the subsequent one conducted by NBS. This does not imply any endorsement or criticism by NBS. 


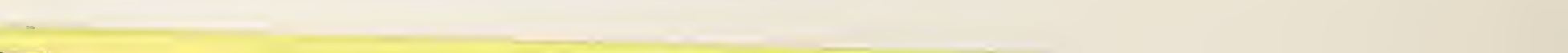




\section{CONTENTS}

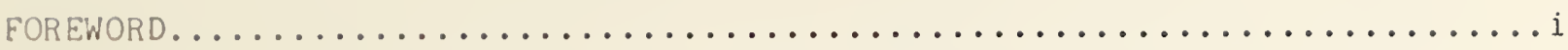

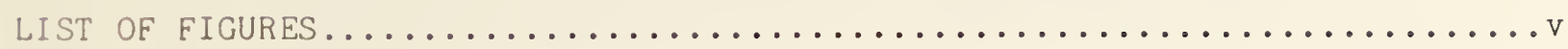

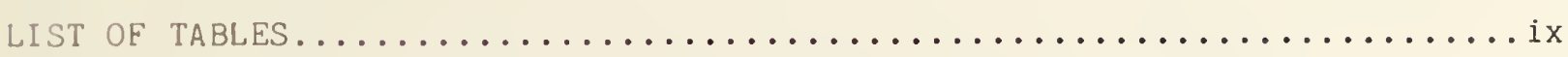

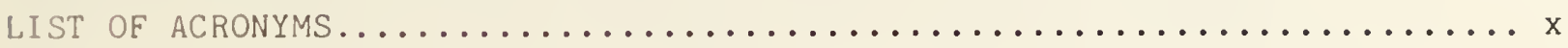

EXECUTIVE SUMMARY ....................................

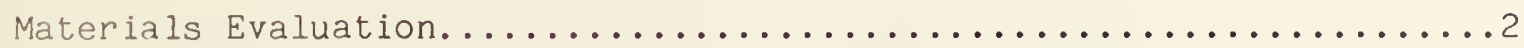

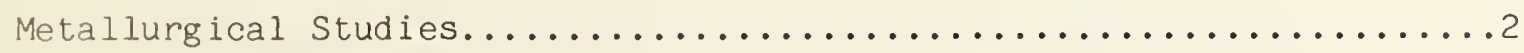

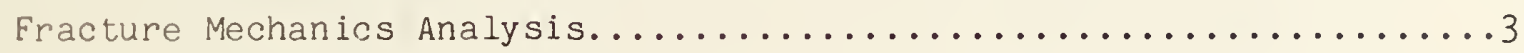

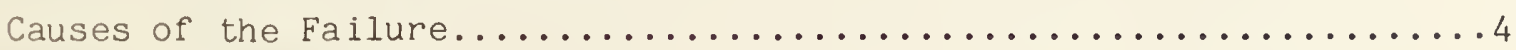

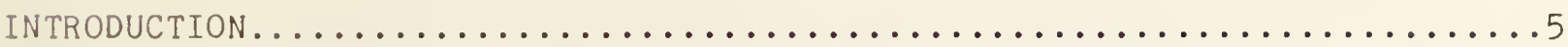

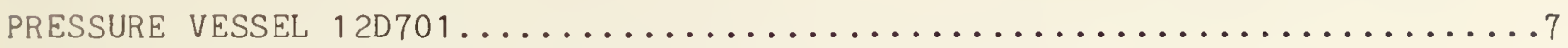

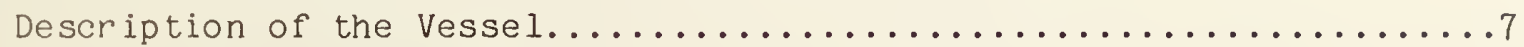

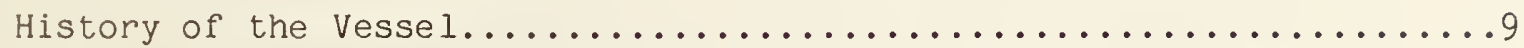

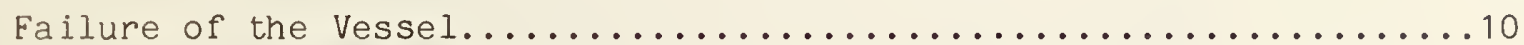

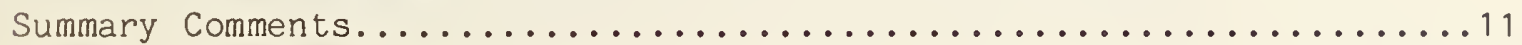

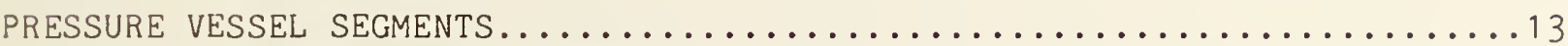

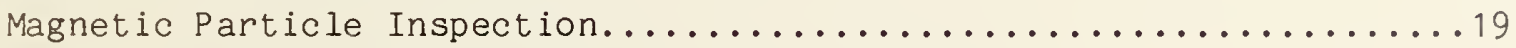

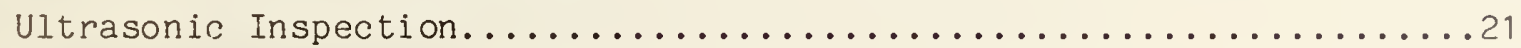

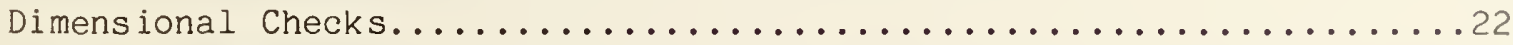

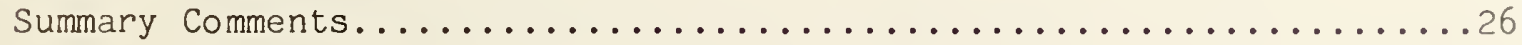

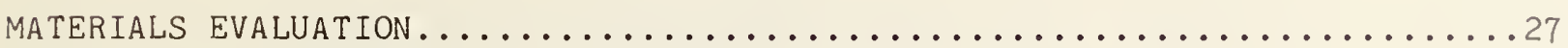

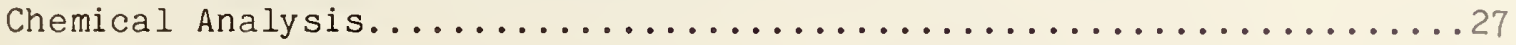

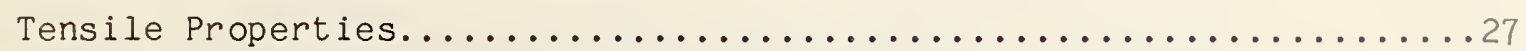

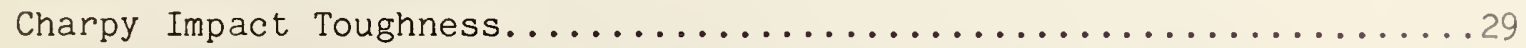

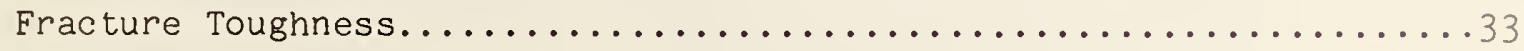

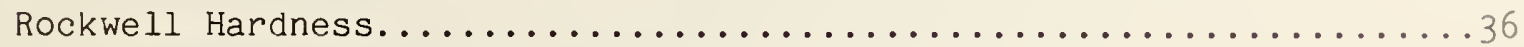

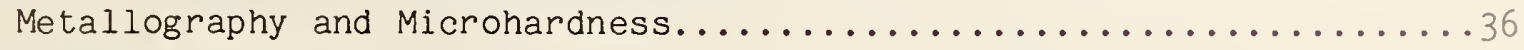

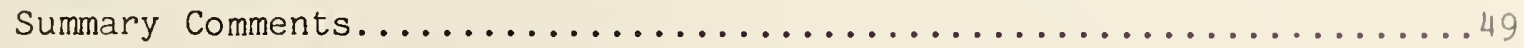


CORROSION AND HYDROGEN CRACKING TESTS......................... 51

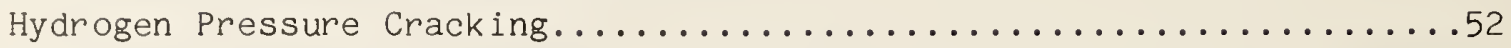

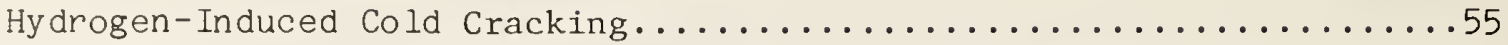

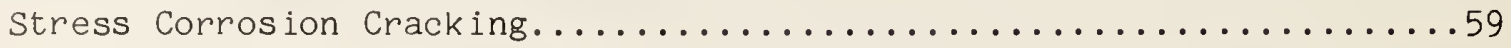

Galvanic Corrosion.................................. 61

Fracture Mechanics Test for Stress Corrosion Cracking.............65

Chemical Analysis of Corrosion Products...................67

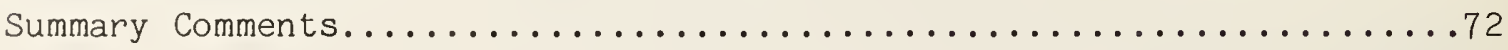

FRACTURE SURFACE OBSERVATIONS..........................

Information Received from the Fire Marshal's Investigation.........73

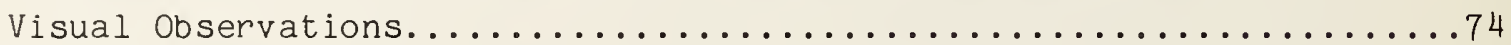

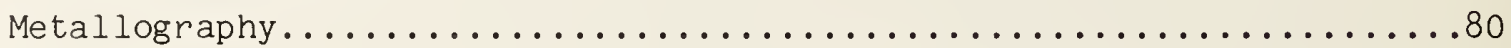

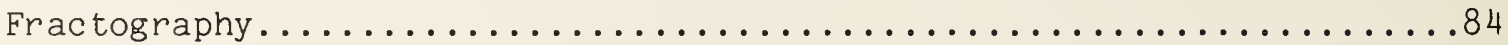

Microchemical Analysis of the Black Deposits..................89

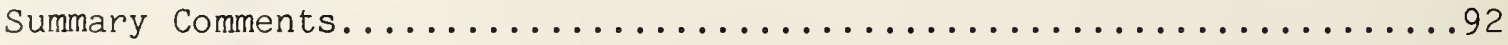

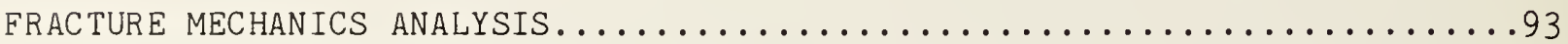

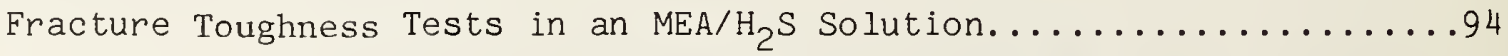

Fracture Toughness Tests on Hydrogen-Charged Specimens............95

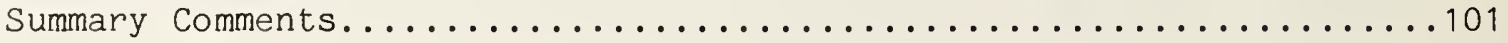

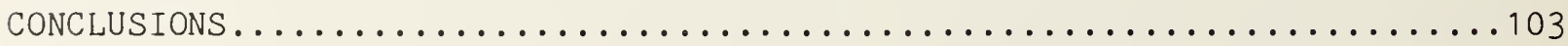

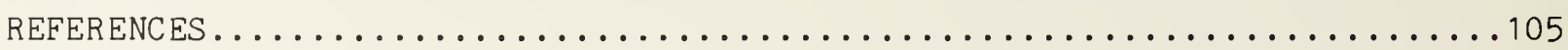

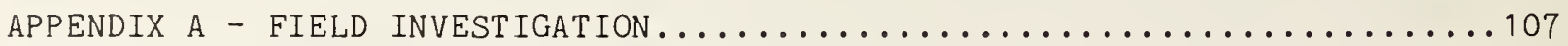

APPENDIX B - MAGNETIC PARTICLE INSPECTION...................... 139

APPENDIX $C$ - ULTRASONIC INSPECTION FOR DELAMINATION............... 159

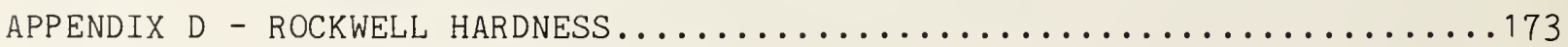

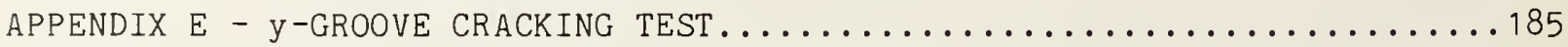

APPENDIX F - REPORT OF ANALYSIS BY THE ELECTRON PROBE MICROANALYZER

OF FRACTURE SURFACE SPECIMENS........................ 195 
Figure 1. Schematic of pressure vessel 12D701..................

Figure 2. Locations of the pieces of pressure vessel 12D701

investigated by NBS: Rings 1,2 , and 3 and

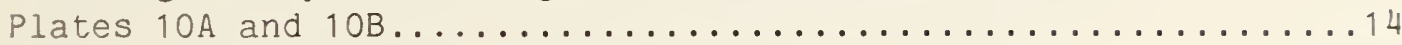

Figure 3. Rings 1,2 , and 3 showing locations of all cutouts..........15

Figure 4. Specimen locations in plates cut from Ring $1 \ldots \ldots \ldots \ldots \ldots \ldots$

Figure 5. Specimen locations in plates cut from Ring $3 \ldots \ldots \ldots \ldots . \ldots . . .20$

Figure 6. Summary of magnetic particle inspection results...........23

Eigure 7. Wall thickness measurements near the fracture surface.......25

Figure 8. Charpy specimens and their notch locations....................

Figure 9. Single-edge-notch-bend specimens for fracture

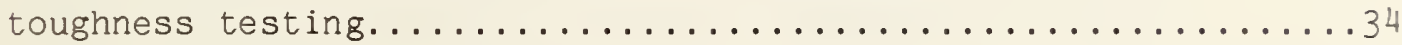

Figure 10. Notches in fracture toughness specimens...................... 35

Figure 11. Macrostructure of weld $1 / 2$ at CC $1.5 \mathrm{~m} \ldots \ldots \ldots \ldots \ldots \ldots \ldots$

Figure 12. Microstructure near crack B in HAZ 1 shown in Figure $11 \ldots . \ldots 39$

Figure 13. Macrostructure of Weld $2 / 3$ at CC $1.8 \mathrm{~m}$ and micro-

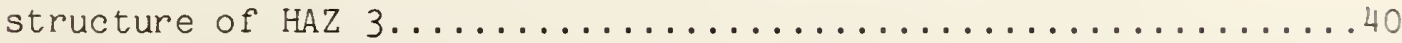

Figure 14. Microhardness of HAZ 3 in Weld $2 / 3$ at CC $1.8 \mathrm{~m}$

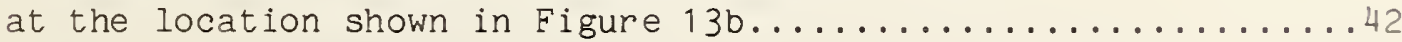

Figure 15. Macrostructure and microstructure of vertical

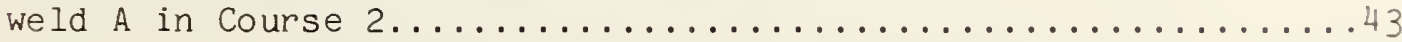

Figure 16. Microhardness of vertical Weld $\mathrm{A}$ and its HAZ in Course 2 at location $B$ shown in Figure 15a. Etchant: $2 \%$ nital........44

Figure 17. Microstructure of Weld $1 / 2$ at CC $1.0 \mathrm{~m}$ and base metal cracks on the inner surface of Course $2 \ldots \ldots \ldots \ldots \ldots \ldots \ldots$

Figure 18. Microhardness of the HAZ of the Monel-to-steel weld

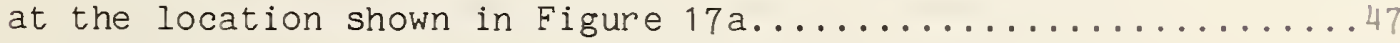

Figure 19. Hydrogen pressure cracking in Course 1 at CC $3.9 \mathrm{~m} \ldots \ldots . . \ldots 48$

Figure 20. Specimen for measuring susceptibility to hydrogen pressure cracking. 
Figure 21. Blistering on surface of specimens after

hydrogen pressure cracking tests....................... 54

Figure 22. Metallography of cracking in specimens after hydrogen

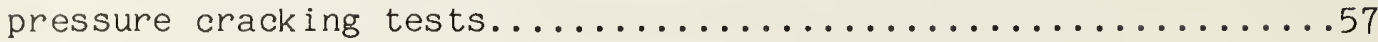

Figure 23. Specimen for y-groove weldability test................ 58

Figure 24. Cross section of y-groove test specimen of

Course 1 steel welded to Course 2 steel showing

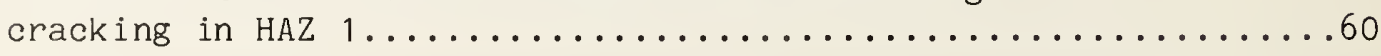

Figure 25. Test apparatus for galvanic corrosion studies............63

Figure 26. Specimen for fracture mechanics test of

stress corrosion cracking susceptibility..............66

Figure 27. Fracture surfaces of specimens after completion

of fracture mechanics tests of stress corrosion

cracking susceptibility. Arrows point to

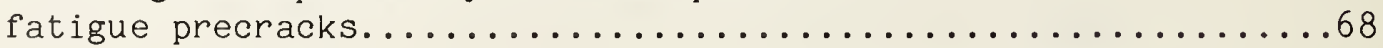

Figure 28. Sketch of fracture surface showing pre-existing

cracks (shaded areas), fracture path, and direction

of fracture propagation.............................

Figure 29. Section of fracture removed for metallographic

studies with arrows showing cracks on inside

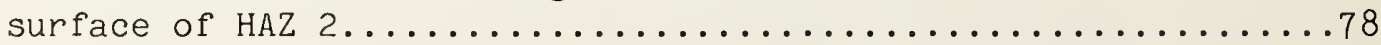

Figure 30. Piece cut from Ring 1 where the fracture passed

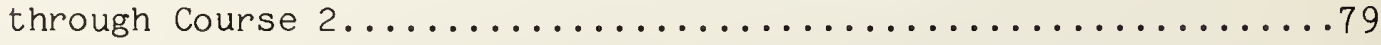

Figure 31. Metallographic sections through the fracture

surface at the location of the initiation crack............81

Figure 32. Microstructure of Weld $2 / 3$ at CC $7.6 \mathrm{~m}$, metallography of cracks in HAZ 2 and HAZ 3 ,

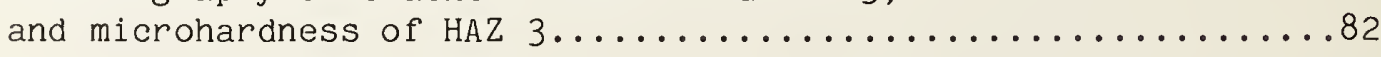

Figure 33. Macrostructure of Weld $2 / 3$ at CC $5.9 \mathrm{~m}$ and

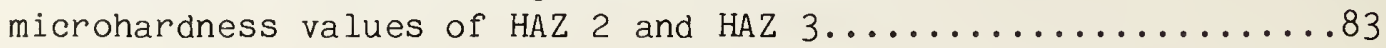

Figure 34. Macrostructures at two locations where a

black deposit was not found on the fracture surface..........85

Figure 35. FMI [1] photographs of the macrostructure

of Weld $1 / 2$ and fractograph at CC $5.2 \mathrm{~m}$.

The letters show corresponding areas...................87

Figure 36. FMI [1] photographs of the macrostructure of

Weld $1 / 2$ and fractograph at CC $7.3 \mathrm{~m}$. The letters

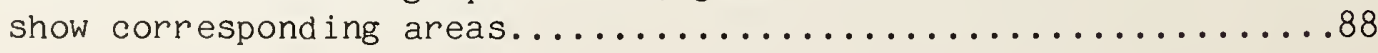


Figure 37. Fractographs of the crack in HAZ 2 (shown in Figure 32) of

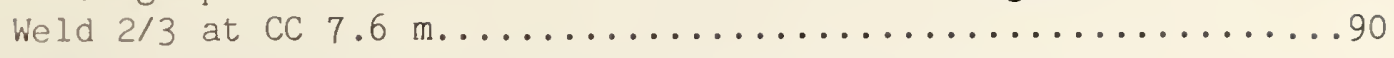

Figure 38. SEM fractographs of hydrogen pressure cracks in Course 1.....91

Figure 39. CTOD vs. crack extension, $\triangle a$, curves for the Course 1

side of weld $1 / 2$ after hydrogen charging. Tested

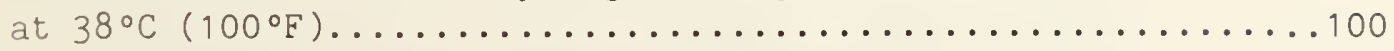

Figure C1. Ferritic steel plate with machined slots used for

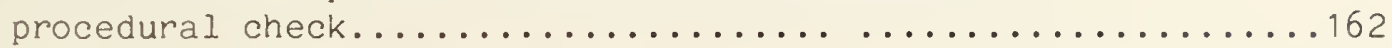

Figure C2. Oscilloscope photographs of measurements made

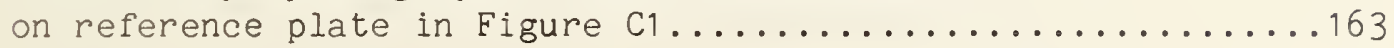

Figure C3. Samples of typical oscilloscope traces......................66

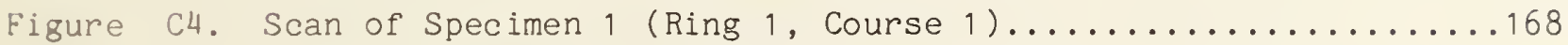

Figure C5. Scan of Specimen 2 (Ring 3, Courses 2 and 3)............ 169

Figure C6. Scan of Specimen 3 (Ring 3, Courses 2 and 3)...........170

Figure C7. Results of the ultrasonic inspection for

delaminations near the fracture surfaces in Rings 1 and $2 \ldots 171$

Figure D1. Hardness traverses of the weld between

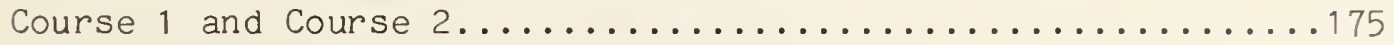

Figure D2. Hardness traverses of the weld between

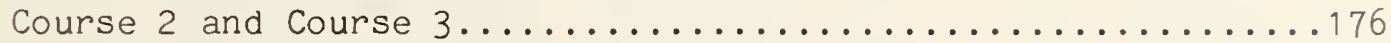

Figure D3. Hardness traverses of the weld between

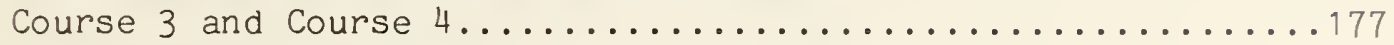

Figure D4. Hardness traverses of the weld between

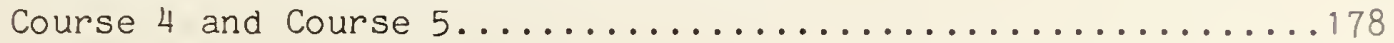

Figure D5. Hardness traverses across vertical

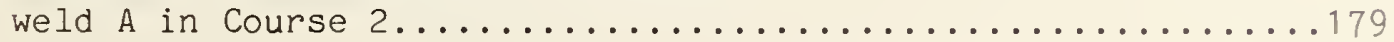

Figure D6. Hardness traverses across vertical

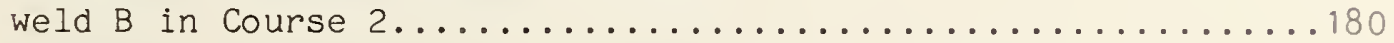

Figure D7. Hardness traverses across vertical weld $\mathrm{C}$ in Course 2......181

Figure D8. Hardness traverses across the vertical weld in Course $1 \ldots \ldots 182$

Figure D9. Hardness traverses across the vertical weld in Course $3 \ldots \ldots 183$

Figure D10. Hardness traverses across the vertical weld in Course $5 \ldots \ldots 184$ 
Figure E1. Plate and groove dimensions for the

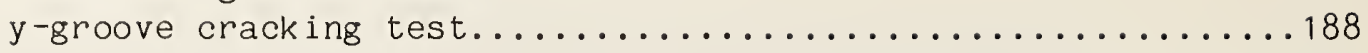

Figure E2. Schematic of the weld progression in the center section......188

Figure E3. Typical cross section of the weld at the center

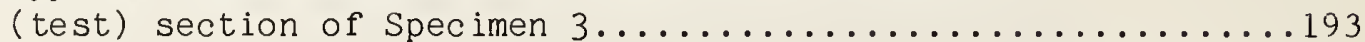

Figure E4. Typical crack along the HAZ in the Plate 1 side of the groove, extending $20 \%$ of the leg length

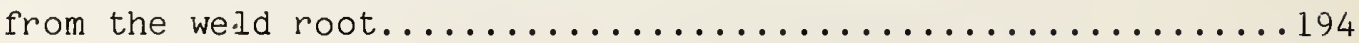

Figure F1. Examples of the EDS spectra.............................

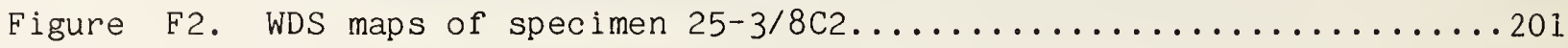

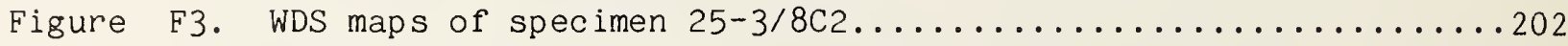

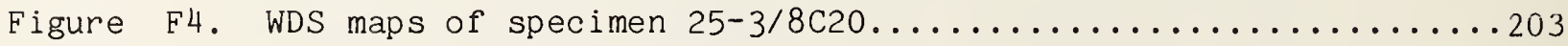

Figure F5. Energy dispersive spectra of the pitted area of

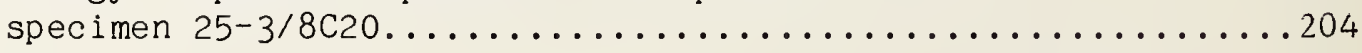


Table I. Chemical compositions (weight percent) of the steel plates used for Courses 1,2 , and 3 and of Welds $1 / 2,2 / 3$ and the vertical weld in

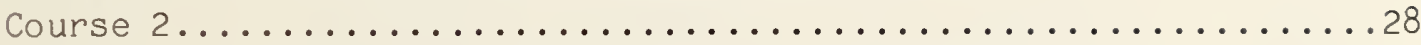

Table II. Tensile properties of Courses 1, 2, and 3 and Weld $1 / 2 \ldots \ldots \ldots$

Table III. Charpy V-notch impact toughness of Courses 1

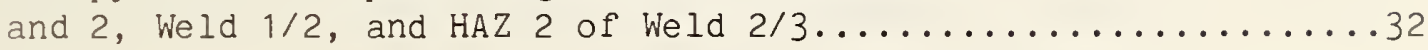

Table IV. Fracture toughness test results....................... 37

Table $\quad V$. Results of hydrogen-pressure cracking tests............... 56

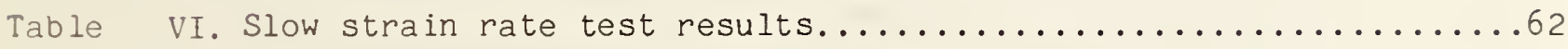

Table VII. Results of the galvanic corrosion tests.................64

Table VIII. Results of the fracture mechanics test for

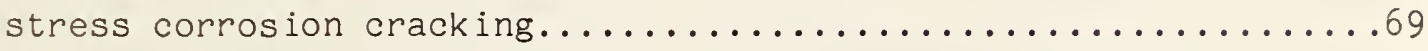

Table IX. Chemical composition (weight precent) of scale

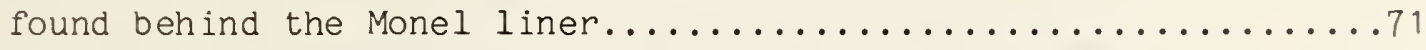

Table $\mathrm{x}$. Fracture toughness test results for specimens

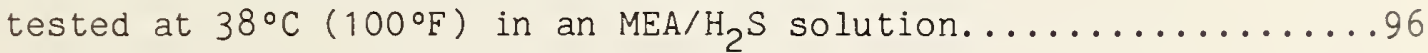

Table XI. Fracture toughness test results for hydrogen-

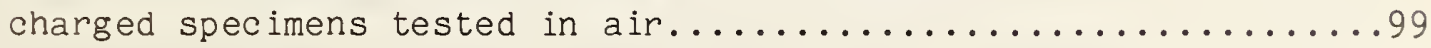

Table AI. Design information for pressure vessel 12D701............ 120

Table AII. Plate thicknesses according to code and

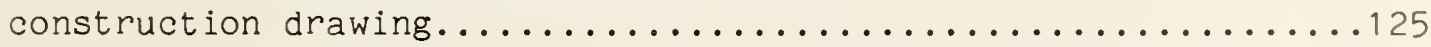

Table BI. Magnetic particle inspection of Ring 1 , Course $1 \ldots \ldots \ldots \ldots$..... 141

Table BII. Magnetic particle inspection of Ring 2, Course $2 \ldots \ldots \ldots \ldots 147$

Table BII. Magnetic particle of Ring 3, Course $2 / 3 \ldots \ldots \ldots \ldots \ldots \ldots . \ldots . \ldots 153$

Table CI. Graphical symbols used for ultrasonic measurements.......... 165

Table EI. Results for the y-groove cracking tests....................... 192

Table FI. EDS qualitative analysis of rough specimens from

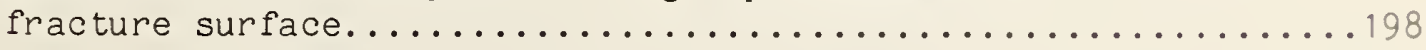




\section{LIST OF ACRONYMS}

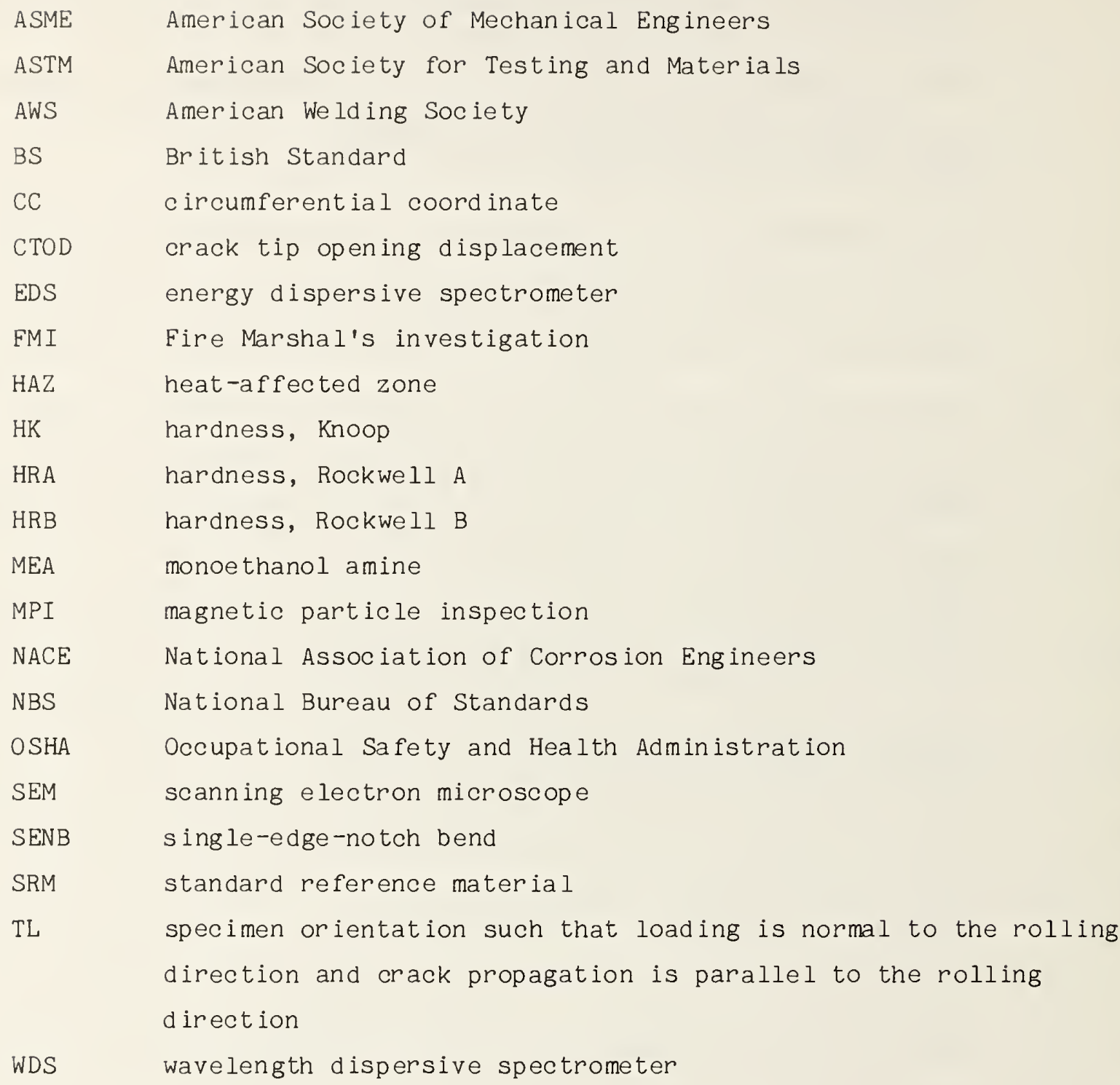


On July 23, 1984, a pressure vessel rupturec at ine Chicago lefineny o: the Union Oi: Company and caused an explosion and fine that killed serenteen. people and resulzed in extensive property damaze. Ine occupational Safety and Health fdministration (OSHA) requested the lietional Bureau of Stancards (WBS) to conduot an investigation into the cause of the failune. Inis neport sumarizes the results of these studies and identifies the probable ceuses of the failure.

The rupturec pressure ressel was an amine absonber tower used to strip hydrogen sulfide frow a process stream of propane and butane. It has a 13.8 m (51.5 ft.) high, $2.6 \mathrm{~m}$ (3.5 f..) diauter tank tade of $25 \mathrm{II}(1.0 \mathrm{in.})$ thick plates of type ASTM $\$ 516$ Crace 70 steel. It was constructed in accordance with the ASME Boiler enc Pressure Vessel Code by welding Six cylindrical sections together between two ellipsoidal ends. The cylindrical sections, called courses, were cesigneted as counses i through 5 , from bottom to top. The ressel was built in 1958 and put into semice in i970; thereafter it was shutdown and inspected at trio year interrals.

In i 974 , Course 2 was replaced because extensive hydrogen blister cracking was discorered in the oniginal plate. It was replaced on the site with a new plate of the same grade of steel, which was welced in place by the shielded tetal arc process. Lt the tite of inis repair, hydrogen blister cracking was also detected in the adjacent plate, course i. During the next scheduled shutdom in 1975, a Monel linen was installed on the bottor of the vessel, including most of Counse 1 , to copreat the problem. Wo funther modifications were made in the subsequent biennial inspectiors.

hbout fifteen minutes prior to the expioston, a unit cperator ries notifiec of a leak in the wall of the pressure ressel. The openator, winile attemoting to close the hydrocaroon inlet valve, noticed that the leak had increased in size. He ran for coven and was knocked orer oy a vapor blast just before the explosion. The pressure vessel rupturec into two wain. pieces. At the time of the rupture, the uppen it $\mathrm{m}(-6 \mathrm{ft}$ ) section of the ressel was propelled nearly i $k=(0.6 \mathrm{mi.})$ awaj. The lower portion of the vessel remained in its oniginal position at the refinery. The fracture path was primarily in Course $i$, adjacent to the field weId joining course 1 to Course 2 (the neplaced section). 
After the incident, the Fire Marshal of the State of Illinois impounded the vessel pieces. Three ring sections and two plates were cut from the vessel for a failure investigation conducted by Packer Engineering Associates, for the Fire Marshal. The ring sections, each $0.9 \mathrm{~m}$ (3 ft.) high, included sections containing the mating fracture surfaces, i.e., the upper portion of Course 1 and the lower portion of Course 2, and a section centered on the repair weld joining Courses 2 and 3 . Several small pieces were removed from these sections in the Fire Marshal's investigation and were not available to NBS. The main part (over $99 \%$ by weight) of the ring sections and test plates were provided to NBS. The present investigation consisted of an evaluation of the vessel materials, metallurgical studies, and a fracture mechanics analysis.

\section{Materials Evaluation}

Tests conducted to evaluate the materials of construction revealed that the steel plates and the welds met the specified requirements for chemical composition and tensile properties. Corrosion tests showed that the steel plates were susceptible to hydrogen pressure cracking in an aqueous solution $(\mathrm{pH}=3)$ saturated with hydrogen sulfide $\left(\mathrm{H}_{2} \mathrm{~S}\right)$, but not to stress corrosion cracking in an amine solution containing $\mathrm{H}_{2} \mathrm{~S}$. The galvanic corrosion tendencies between the steel and the Monel liner were measured and found to be insignificant. Fracture property measurements indicated that the welds were tougher than the plate.

\section{Metallurgical Studies}

Various metallurgical techniques were used to examine the fracture surface, the path of the fracture, and secondary cracks. When NBS received the vessel segments, the fracture surfaces were covered with rustlike deposits and evidence regarding the origin of the fracture was not clearly discernible. The fracture path followed the HAZ on the Course 1 side of the weld for most of the circumference. The fracture surface did not have either the chevron patterns characteristic of brittle fracture or the shear lips characteristic of ductile fracture. Under low-power magnification, the texture of the fracture surface appeared fibrous or "woody." 
After the fracture surface was cleaned with high-pressure steam, a black deposit, previously observed and photographed in the Fire Marshal's investigation, could be seen. The black deposit extended from the inner surface to beyond midthickness over nearly thirty percent of the circumference. Chemical analysis of the black deposit revealed it to be rich in sulfur. Since the deposits almost certainly formed prior to fracture, they delineated cracks that existed in the vessel at the time of rupture.

Metallography, fractography and microhardness measurements revealed that these pre-existing cracks initiated adjacent to the repair welds in areas of hard microstructure that are susceptible to hydrogen stress cracking. The cracks initiated along the inside surface of the vessel at the fusion line and propagated along a straight path, through the hardened region in the HAZ toward the base metal. Upon reaching the base metal, crack propagation continued in a zigzag path. Fractographic examination of typical crack surfaces revealed that the zigzag cracking was due to hydrogen pressure cracking. Cracks of this type formed on both sides of the repair welds joining replacement Course 2 to Courses 1 and 3 . In the Course $1 \mathrm{HAZ}$, one such crack, about $800 \mathrm{~mm}$ (31 in.) long, had propagated nearly through the wall thickness prior to the final rupture. When the crack depth exceeded 90 to $95 \%$ of the wall thickness, the remaining ligament of material tore, causing a leak that spread the approximate length of the pre-existing crack and initiated the final fracture. Growth of the crack was facilitated by its uniform depth over most of its length.

\section{Fracture Mechanics Analysis}

A fracture mechanics analysis was conducted to determine if the $800 \mathrm{~mm}$ (31 in.) long crack was sufficient to cause rupture of the vessel at the operating stress level of $35 \mathrm{MPa}(5.1 \mathrm{ksi})$. The fracture criterion used was the crack tip opening displacement (CTOD), a measure of the driving force for fracture. The fracture toughness by this criterion, i.e., the critical CTOD at which fracture occurs, was measured to be a minimum of $0.17 \mathrm{~mm}(0.0066$ in) for specimens notched in the HAZs of Courses 2 and 3. The CTOD of the $800 \mathrm{~mm}$ (31 in.) long crack was calculated to be $0.064 \mathrm{~mm}(0.0025 \mathrm{in.})$. Thus, by the CTOD criterion, the crack should have been stable, and sudden rupture should not have occurred. However, a key feature of the vessel's condition was not accounted for in this analysis: the steel plates of Courses 1 and 2 had been 
charged with hydrogen as indicated by the presence of blisters, delaminations, and hydrogen-induced cracking on these plates. Therefore, additional fracture toughness tests were conducted on steel samples notched in HAZs of Courses 1, 2, and 3 and charged with hydrogen. The measured CTOD values ranged from 0.064 to $0.096 \mathrm{~mm}(0.0025$ to $0.0038 \mathrm{in.})$. The agreement between these measured values and the calculated CTOD indicates that fracture of the vessel was possible at a stress level of $35 \mathrm{MPa}(5.1 \mathrm{ksi})$ for an $800 \mathrm{~mm}$ (31 in.) long crack because the toughness of the steel was reduced by hydrogen embrittlement.

\section{Causes of the Failure}

The incident at the Chicago Refinery was caused by the rupture of a pressure vessel. The vessel fractured along a path that was weakened by extensive cracking adjacent to a repair weld joining a replacement section to the vessel. These pre-existing cracks initiated in areas of hard microstructure known to be susceptible to hydrogen stress cracking. This hard microstructure formed during the repair welding of the replacement section, and at the surface, it was not tempered by subsequent weld passes or thermal treatment. The cracks grew through the vessel wall due to hydrogen pressure cracking. When the depth of the largest of these pre-existing cracks exceeded 90 to $95 \%$ of the wall thickness, leakage occurred because the thin ligament of steel remaining in the cracked section ruptured. Because the depth of the pre-existing crack was relatively uniform, the thin ligament continued to tear and caused the through crack to grow to a length of about $800 \mathrm{~mm}$ (31 in.). This crack triggered the final fracture at the operating stress level of $35 \mathrm{MPa}(5.1 \mathrm{ksi})$ because the toughness of the vessel steel was reduced by hydrogen embrittlement. 


\section{INTRODUCTION}

On July 23, 1984, there was an explosion followed by a fire at the Chicago Refinery of the Union Oil Company of California. Seventeen refinery employees were killed, and property damage was extensive. Eyewitness reports and refinery records indicate that the substance that exploded was a mixture of propane and butane that leaked from a ruptured pressure vessel, designated 120701. This vessel, a $18.8 \mathrm{~m}$ (61.5 ft.) high steel cylinder, was an amine absorber tower used to strip hydrogen sulfide gas $\left(\mathrm{H}_{2} \mathrm{~S}\right)$ from the propane and butane process stream. After the fire, the upper $14 \mathrm{~m}$ (46 ft.) section of the pressure vessel was found approximately $1 \mathrm{~km}(0.6 \mathrm{mi}$.) from its original site. The lower section of the vessel remained attached to its base.

Soon after the incident, the Occupational Safety and Health Administration (OSHA) requested the National Bureau of Standards (NBS) to conduct an investigation into the cause of the pressure vessel failure. A field investigation was conducted during the week of July 30, 1984; it is summarized in Appendix A. At this time, access to the vessel was restricted, and the investigation was limited to visual observations of the ruptured vessel and the failure site.

From the time immediately following the failure until August 8, 1985, the failed pressure vessel was in the custody of the Illinois state Fire Marshal. During this period, a failure investigation was conducted by Packer Engineering Associates for the Fire Marshal; hereafter it is referred to as the Fire Marshal's Investigation (FMI) [1]. On the basis of a metallurgical examination of the vessel, the FMI concluded that the failure was caused by hydrogen induced cracking in the hardened area adjacent to a repair weld. This weld was done in the field during the replacement of a segment of the vessel.

The present investigation began in August 1985 with a brief review of the information available from OSHA and the FMI regarding pressure vessel $12 \mathrm{D} 701$ and its failure. On the basis of this review, five major tasks were planned to reveal the probable causes of the failure: 
1. Examination of the vessel pieces

2. Materials evaluation

3. Corrosion and hydrogen cracking studies

4. Fracture surface observations

5. Fracture mechanics analysis

This report begins with general information about pressure vessel 12D701 and its failure and continues with sections covering the results of the major tasks and the probable causes of the pressure vessel rupture. 
The ruptured pressure vessel was an amine absorber tower designated 12D701. The vessel was part of the unsaturated gas plant (Unit No. 12) located at the south end of Union Oil's Chicago Refinery in Lemont, Illinois. In this section information obtained from OSHA regarding the vessel and its failure is summarized.

\section{Description of the Vessel}

Pressure vessel 12D701 was a $18.8 \mathrm{~m}$ (61.5 ft.) high, $2.6 \mathrm{~m}$ ( $8.5 \mathrm{ft}$. diameter, cylindrical tank shown schematically in Figure 1 . Its six cylindrical sections are designated Courses 1 through 6 . The welds joining the courses are identified with the same numbers; e.g., the weld joining Course 1 to Course 2 is Weld 1/2. It was constructed of $25 \mathrm{~mm}$ thick steel plates to the requirements of the ASME Boiler and Pressure Vessel Code, Section VII [2]. Its design and operating conditions were:

\begin{tabular}{lll} 
& \multicolumn{1}{c}{ Design } & $\frac{\text { Operating }}{\text { Pressure }}$ \\
\cline { 2 - 3 } & $1.6 \mathrm{MPa}(230 \mathrm{psi})$ & $1.4 \mathrm{MPa}(200 \mathrm{psi})$ \\
Temperature & $60^{\circ} \mathrm{C}\left(140^{\circ} \mathrm{F}\right)$ & $38^{\circ} \mathrm{C}\left(100^{\circ} \mathrm{F}\right)$
\end{tabular}

The materials for the shell and heads were:

Steel Plate ASTM A516 Grade 70

Welding Materials ASME SA233 for shielded metal arc welding (SMAW) ASME SA558 No. EL12 for submerged arc welding (SAW) ASTM A558 No. F70-xxxxx for the SAW flux.

Preheating and postweld stress relief were not specifically required.

The function of the vessel was to remove $\mathrm{H}_{2} \mathrm{~S}$ from the propane/butane process stream by a counterflow process. A $20 \%$ solution of monoethanol amine (MEA) in water was used to absorb the $\mathrm{H}_{2} \mathrm{~S}$ from the mixture of propane and butane. Under the operating conditions of $1.4 \mathrm{MPa}$ (200 psi) and $38^{\circ} \mathrm{C}$ $\left(100^{\circ} \mathrm{F}\right)$, the mixture was a liquid. The hydrocarbon liquid contaminated with $\mathrm{H}_{2} \mathrm{~S}$ entered near the bottom of the vessel and, owing to its lower density, 


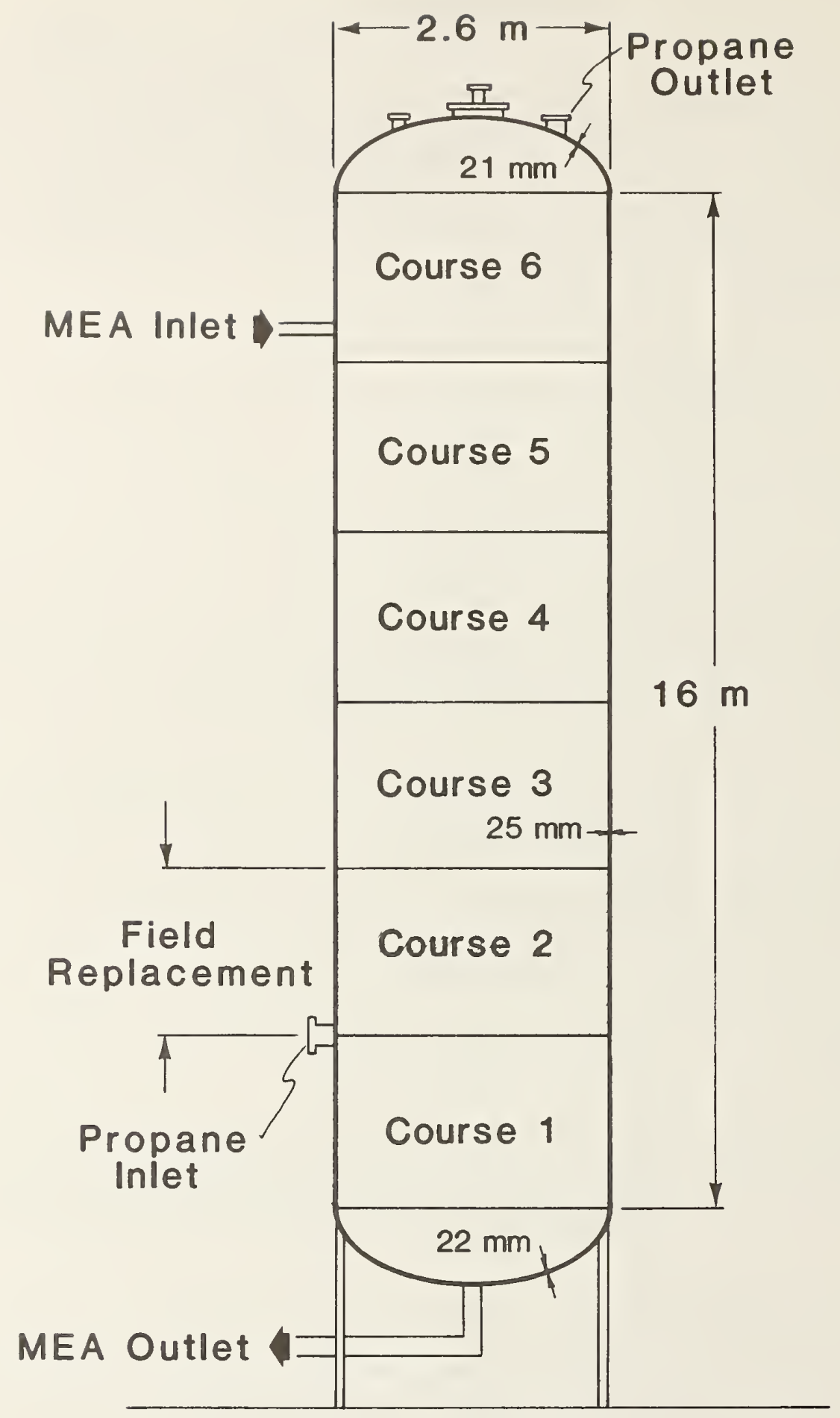

Figure 1. Schematic of pressure vesse 1 12D701. 
flowed upward to the outlet at the top of the vessel. The lean MEA entered the top of the vessel and, as it flowed downiard, absorbed the $\mathrm{H}_{2} \mathrm{~S}$ from the hydrocarbon liquid. Contact between the liquids was increased by a series of $\mathrm{n}$ ine perforated trays spaced at $1.5 \mathrm{~m}(5.0 \mathrm{ft.})$ intervals. The trays had open sections that alternated left and right and directed the counterflowing liquids. The hydrocarbon liquid stripped of $\mathrm{H}_{2} \mathrm{~S}$ exited the vessel at the top and continued to the next processing step. The $\mathrm{MEA}$, rich in $\mathrm{H}_{2} \mathrm{~S}$, exited at the bottom of the vessel, went through a regenerator that removed the $\mathrm{H}_{2} \mathrm{~S}$, and then recirculated through the vessel.

\section{History of the Vessel}

Pressure vessel 12D701 was built in 1968 and put into service in 1970. Thereafter it was shut down and inspected for corrosion damage at two-year intervals.

During the 1972 inspection, hydrogen blisters and delaminations were detected in Course 2, and as a result, Course 2 was replaced during the 1974 shutdown. The new course was made of the same type of steel plate: $25 \mathrm{~mm}$ (1.0 in.) thick, ASTM A516 Grade 70, in the as-rolled condition. The new course was installed in three segments, each of which was $2.7 \mathrm{~m}$ ( $9.0 \mathrm{ft}$.) high (the plate width) and $1 / 3$ of the circumference in length. The segments were welded in place by the shielded metal arc process. Details of the repair procedures were not made available to NBS.

During the 1974 inspection, numerous small hydrogen blisters were found in Course 1. In 1976, more blisters were found and delaminations were detected by ultrasonic inspection. As a remedial action, a Monel liner was installed during this shutdown. The liner, $2.5 \mathrm{~mm}(0.10 \mathrm{in.})$ thick, covered the bottom head and Course 1 up to the bottom of the first tray [about $250 \mathrm{~mm}$ (10 in.) below Weld 1/2]. In the region where the tray was open (the downcomer), the Monel liner extended up to Weld 1/2. The Monel liner was welded to the vessel by the gas metal-arc process with plug welds at the center width of the Monel strips and seam welds at the edges. Installation procedures were not made available to NBS.

No modifications or repairs were made to the pressure vessel during the 1978, 1980, and 1982 shutdowns. In 1984, leaks were found in the Monel liner and they were repaired by welding. 


\section{Failure of the Vessel}

At 5:38 p.m. on Monday, July 23, 1984 there were ten short blasts from a whistle at the Chicago Refinery, indicating something was wrong. An eyewitness report by a unit operator described the events as follows. A refinery worker observed a leak in pressure vessel $12 D 701$ and notified the operator who was stationed near the vessel. The operator checked the vessel and saw a vapor plume about $6 \mathrm{~m}$ (20 ft.) in length coming out of the vessel near the propane-butane inlet valve. He also walked around the vessel to see if there were any other leaks, and none was observed. Then he called the fire department, and presumably, this is when the whistle sounded. The operator wanted to close the inlet valve, but access to the valve from a ladder mounted on the side of the vessel was blocked by the vapor plume. Therefore, he put on a breathing apparatus, obtained a ladder, erected it near the in let valve, climbed the ladder and partially closed the valve. Then he noticed that the leak had increased. He climbed down the ladder just as the fire department was arriving. He estimated that the crack was about $0.6 \mathrm{~m}$ (2 ft.) long at this time. As he started to run for cover, a vapor blast knocked him over, and as he was crawling behind a concrete barrier, he saw a yellow flash. Presumably, the vapor blast occurred when the vessel ruptured, and the yellow flash occurred soon after when the vessel contents exploded. The explosion occurred at 5:53 p.m., 15 min. after the whistle sounded.

The explosion was followed by a fire that caused another vessel to explode at 6:20 p.m., adding more fuel to the fire. The fired continued out of control until after midnight and was not completely extinguished until 2 p.m. on July 24. Seventeen refinery workers were killed by the explosion and fire. 


\section{Summary Comments}

The information received at the outset of this investigation indicated that:

1. The vessel had a history of hydrogen-induced blisters and delaminations in Courses 1 and 2 .

2. The source of hydrogen was the $\mathrm{H}_{2} \mathrm{~S}$ in the process stream.

3. The $\mathrm{H}_{2} \mathrm{~S}$ tended to collect in the lower portion of the vessel because of the counterflow process.

4. The fracture was preceded by one leak that grew in size for more than 15 min.

5. At the time of rupture, the crack was approximately $0.6 \mathrm{~m}$ ( $2 \mathrm{ft}$.) in length; it was located between the ladder and the inlet valve at the approximate level of the valve.

6. The failure of pressure vesse 1 12D701 caused the explosion and fire. 

The pressure vessel ruptured into two main pieces. At the time of the rupture, the upper $14 \mathrm{~m}$ (46 ft.) section of the pressure vessel was propelled about $1 \mathrm{~km}(0.6 \mathrm{mi}$.) from its original location. Apparently, vaporization of the liquefied gases in the vessel served as the propellant when the pressure was released by the rupture. The crash landing flattened the vessel along most of its length. It evidently landed on its top, which was crushed, and thus the fracture surface did not strike the earth on impact.

The lower portion of the pressure vessel remained erect and cylindrical in its original position in the refinery. It was exposed to the fire, but experienced only limited fire damage. For example, the white paint on the outside surface remained intact, but it did become powdery.

The fracture path was primarily in Course 1 , adjacent to the field weld joining Course 1 to Course 2 (the replaced section), as shown in Figure 2. The failure investigation was conducted on segments removed from the upper and lower pieces of the vessel as part of the FMI. These consisted of Rings 1, 2, and 3 (three cylindrical sections) and Plates $10 \mathrm{~A}$ and $10 \mathrm{~B}$ (two square plates) cut from the vessel at the locations shown in Figure 2. Samples were removed from each segment and retained as part of the FMI. The remainder of the main segments were shipped to NBS (Boulder, Colorado) for this investigation. In addition, some of the pieces removed in the FMI were sent to NBS and included in this investigation. These are shown as speckled areas in Figure 3. The locations of the samples not received by NBS are shown as blank areas in Figure 3 .

The circumferential coordinates (CC) given in Figure 3 are used throughout the report. The zero position is the centerline of the hydrocarbon inlet piping. When the vessel is viewed from above, the circumferential coordinates are numbered clockwise with zero at 12 o'clock. A particular position along the circumference is identified by CC 非 $\mathrm{m}$, where \# $m$ is the coordinate in meters. The reference piece for marking the coordinates was Ring 1 , which remained nearly circular despite the failure. Position marks were scribed on the outside surface at $305 \mathrm{~mm}$ ( $1 \mathrm{ft.}$ ) 


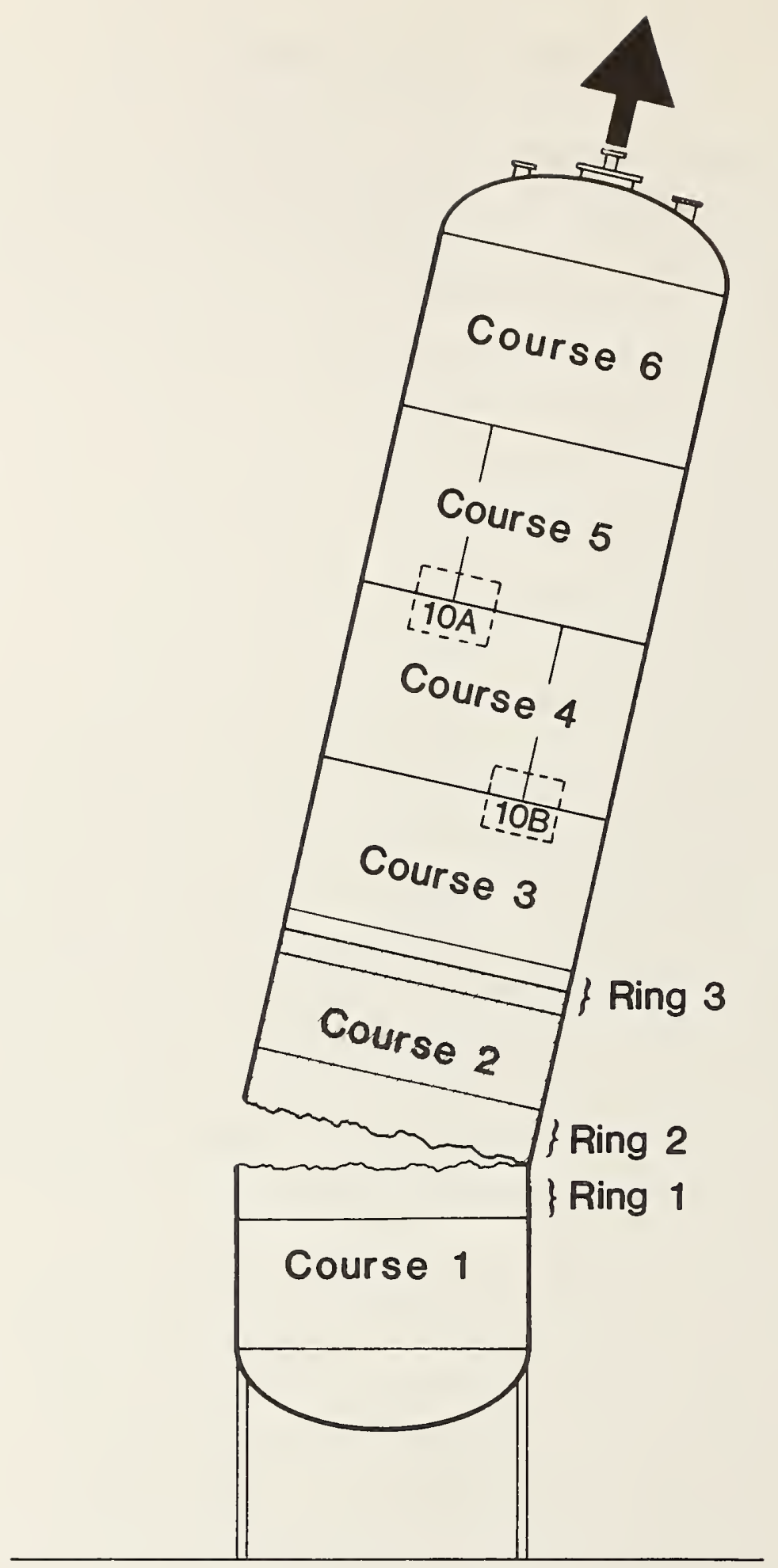

Figure 2. Locations of the pieces of pressure vessel 12D701 investigated by NBS: Rings 1,2 , and 3 and Plates $10 \mathrm{~A}$ and $10 \mathrm{~B}$. 


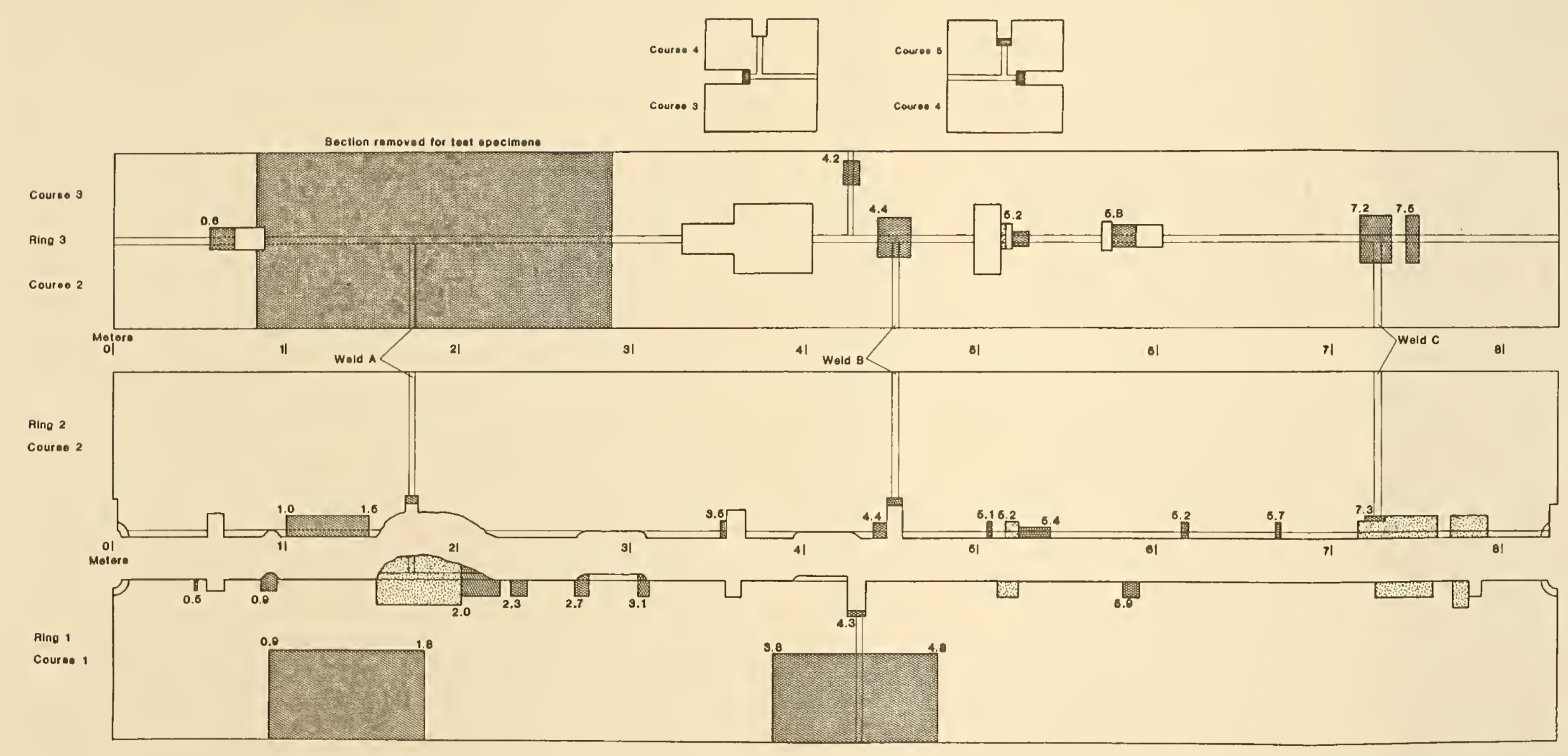

Figure 3. Rings 1,2 , and 3 showing locations of all cutouts. 

intervals. The position marks were transferred to Ring 2 , which was severely deformed. This was done by matching physical features on the mating fracture surfaces and then assuming that the two rings matched between these reference points. Finally, the coordinates were transferred from Ring 2 to Ring 3 . Here, the only reference points were vertical welds A, B, and C. The position marks between these welds were placed at the same intervals as on Ring 2.

Test plates and specimens for metallurgical examination were taken from the vessel pieces for testing and evaluation by NBS; their locations are also shown in Figure 3. The test plates, relatively large pieces, were removed from Rings 1 and 3 with an oxyacetylene torch. The torch-cut edges were removed by cutting a $75 \mathrm{~mm}$ ( 3 in.) strip from the plate edges with a saw. These plates were the main source of material for test specimens. The specimens for metallurgical examination were removed with a hand-held jigsaw and magnetically mounted portable drill press. Use of these tools prevented local overheating of the samples.

Ring 1 is a $0.9 \mathrm{~m}$ ( $3 \mathrm{ft}$.) high cylindrical section of predominately Course 1 steel that is partially lined with Monel. Ring 1 is the uppermost portion of the part of vessel 12D701 that remained attached to the base, and thus it includes the lower fracture surface. It was exposed to the fire at the time of the incident. A test plate, approximately $1.8 \mathrm{~m}(6 \mathrm{ft}.) \times 0.5 \mathrm{~m}$ ( $1.5 \mathrm{ft}$.$) in size, was torch-cut from Ring 1$ with the Monel liner in place. The liner was then removed by grinding off the seam welds that attached the liner to the vessel. The specimens used to evaluate the properties of Course 1 material were located in this plate, as shown in Figure 4 . Between CC $1.62 \mathrm{~m}$ and CC $2.29 \mathrm{~m}$, the fracture deviated from the heat affected zone of Course 1 (HAZ 1) and ran through the Course 2 plate. This section of steel, also shown in Figure 4, was removed during the FMI and sent to NBS in a separate shipment.

Ring 2 is a $0.9 \mathrm{~m}$ ( $3 \mathrm{ft}$.) tall cylindrical section of Course 2 material. It includes the upper fracture surface and most of the repair weld that joined Courses 1 and 2 (Weld 1/2). Ring 2 is the lowest portion of the part of vessel that was propelled from the original site and flattened upon impact; therefore, its fracture surface was not exposed to fire. Numerous specimens were removed from the fracture surface of Ring 2 and used for metallurgical studies. 
Ring 3 was torch-cut from pressure vessel 12D701 about $0.45 \mathrm{~m}$ (1.5 ft.) on either side of the Weld 2/3. Like Ring 2, it was crushed upon impact and was not exposed to the fire. A $2 \mathrm{~m}$ ( $6.6 \mathrm{ft}$.) long section was torch cut from Ring 3 and subsequently saw cut into four test plates. Material from these test plates was used to evaluate Courses 2 and 3 and Weld $2 / 3$. The specimen locations are shown in Figure 5. Weld $2 / 3$ is a repair weld that joined the replacement plate, Course 2 , to an original plate, Course 3 , and thus it is similar to the weld that failed.

Two $0.6 \mathrm{~m} \times 0.6 \mathrm{~m}(2 \mathrm{ft} . \times 2 \mathrm{ft}$.) plates were removed from the vessel above the replacement course. Plate $10 \mathrm{~A}$ includes Courses 4 and 5, Weld 4/5, and the vertical weld in Course 5. Plate $10 \mathrm{~B}$ includes courses 3 and 4 , Weld $3 / 4$, and the vertical weld in Course 4.

\section{Magnetic Particle Inspection}

The inner surfaces of each pressure vessel ring and Plates $10 \mathrm{~A}$ and $10 \mathrm{~B}$ were subjected to magnetic particle inspection (MPI) in the vicinity of each weld. A minimum of $100 \mathrm{~mm}$ ( $4 \mathrm{in.}$ ) above and below each weld was examined in all regions where accessibility permitted. The MPI was done in a darkened room using the wet fluorescent method.

The areas of the vessel subject to MPI were cleaned in several steps:

1. brushed with a fine-wire brass brush and then a plastic fiber brush

2. washed with $1,1,1$ tricholorethane and allowed to dry

3. sprayed with a chlorinated solvent cleaner

After the solvent had evaporated from the flaws, magnetic particles in an oil suspension were sprayed on the areas to be inspected. An ac magnetic yoke with a probe separation adjustable to $150 \mathrm{~mm}$ ( 6 in.) was used to magnetize the region and cause the particles to collect at discontinuities. A $100 \mathrm{~W}$ black light was used to illuminate the fluorescent particles, which have a yellow-green color. The locations of all isolated indications of discontinuites and regions with numerous indications were recorded. 
The results of the MPI are summarized in Figure 6 and Appendix B. The Indications observed were of the linear type associated with cracks open to the surface. There were numerous small indications in the base metal and in the HAZ of Welds $1 / 2$ and 2/3. The three vertical welds (,$B$, and $C$ ) joining the replacement segments of Course 2 were inspected, and only two small indications were detected. Several small (<10 mm long, 0.4 in.) indications were observed in the vertical weld in Course 1, and two isolated indications were found in the vertical weld in Course 3. No indications were observed in Plates $10 \mathrm{~A}$ and $10 \mathrm{~B}$. The results listed in Appendix B generally agree with the inspection results of the FMI [1].

The test plates removed from Rings 1 and 3 were inspected by MPI over the entire inner surface and on each of the saw-cut edges. Two isolated $25 \mathrm{~mm}$ ( $1 \mathrm{in.}$ ) indications were detected on the surface of the Ring 1 test plate. The edges of the Ring 1 test plate had numerous delaminations that appeared to be hydrogen pressure cracks similar to blisters. Most of the cracking detected on the edges was within $6 \mathrm{~mm}(0.23 \mathrm{in.})$ of the inside surface.

On the Ring 3 test plate, no indications were found in the weld or HAZ of Weld 2/3. Small cracks were found near three separate arc strikes. The saw-cut edges of the Ring 3 test plates were inspected and no indications of delamination were detected.

\section{Ultrasonic Inspection}

The ultrasonic inspection task is summarized in this section. Details regarding interpretation of the signals and the complete results are presented in Appendix $C$.

The test plates taken from Rings 1 and 3 were ultrasonically tested for evidence of delamination in order to avoid taking specimens from damaged material. A pulse echo technique was used. Measurements were made at $25.4 \mathrm{~mm}$ ( 1 in.) intervals on the outside surface of the vessel using $12.7 \mathrm{~mm}$ ( 0.5 in.) diameter piezoelectric transducers with a resonant frequency of $10 \mathrm{MHz}$. Extensive regions of delamination were found in the Ring 1 test plate, particularly between the edge cut at CC $3.91 \mathrm{~m}$ and the vertical weld at CC $4.32 \mathrm{~m}$. No regions of delamination were detected in the test plates cut from Ring 3 . 
After detection of such extensive delamination in the Ring 1 test plate, it was decided to survey Rings 1 and 2 by the same technique (except that a $5 \mathrm{MHz}$ transducer was used) to assess the extent of delamination in the vicinity of the fracture. In Ring 1, measurements were taken $25 \mathrm{~mm}$ ( 1 in.) and $76 \mathrm{~mm}$ ( $3 \mathrm{in.}$ ) below the fracture surface at $51 \mathrm{~mm}$ (2 in.) intervals around the circumference and $0.33 \mathrm{~m} \mathrm{(1} \mathrm{ft.)} \mathrm{below} \mathrm{the} \mathrm{fracture} \mathrm{surface} \mathrm{at}$ $0.3 \mathrm{~m}$ ( $1 \mathrm{ft.}$ ) intervals. In Ring 2, measurements were taken $51 \mathrm{~mm}$ (2 in.) and $102 \mathrm{~mm}$ ( $4 \mathrm{in.}$ ) above the fracture surface at $0.3 \mathrm{~m}$ (1 ft.) intervals. Fewer measurements were taken because the Ring 3 test-plate results (Appendix C) indicated a lower susceptibility to delaminations in Course 2.

The results indicate that Course 1 had several areas of delamination and the ultrasonic signals frequently had moderate noise levels between the outer-surface echoes. This noise is an indication of discontinuities such as inclusions in the steel plate. In contrast, no clear indication of delamination was found in Course 2, and typically the ultrasonic signals were free of noise, indicating that the Course 2 plate was cleaner than the Course 1 plate. No clear indication of delamination was found in Course 3 , but the ultrasonic signals frequently had moderate noise levels between the outer-surface echoes. This suggests that the cleaniness levels of Courses 1 and 3 were similar.

\section{Dimensional Checks}

The thickness of Courses 1 and 2 in the vicinity of Weld $1 / 2$ was spotchecked with a micrometer. The results, summarized in Figure 7 , indicate that the thickness was typically equal to or greater than the nominal wall thickness of $25.4 \mathrm{~mm}(1.0 \mathrm{in.})$. The minimum thickness measured was $23.4 \mathrm{~mm}$ ( 0.92 in.), which was well within the corrosion allowance for the pressure vessel. 

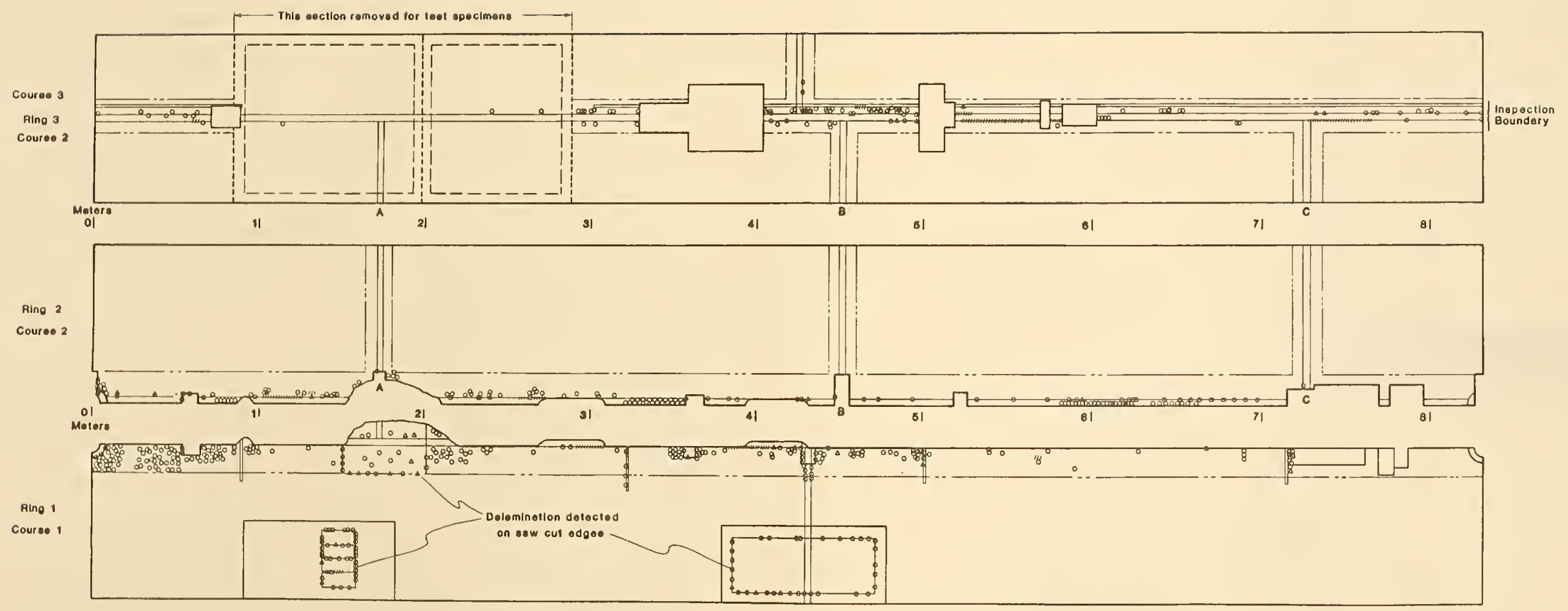
- $<28 \mathrm{~mm}$
- $25-81 \mathrm{~mm}$
(tw) >51 $\mathrm{mm}$

Figure 6. Summary of magnetic particle inspection results. 



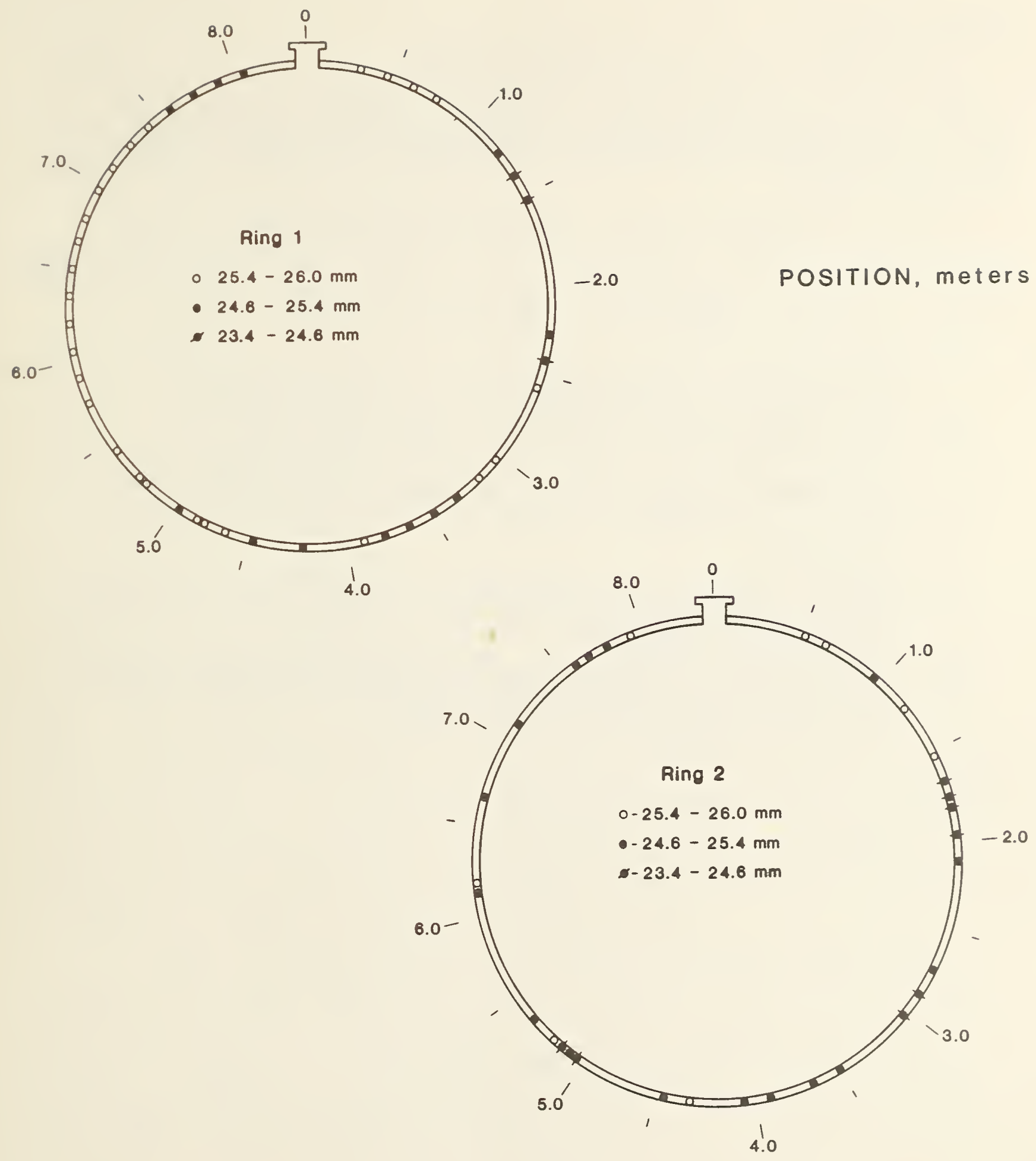

Figure 7. Wall thickness measurements near the fracture surface. 


\section{Summar y Comments}

The pressure vessel fractured into two main pieces along a path adjacent to the field weld joining Course 1 to Course 2 (replaced section). The failure investigation was conducted on three ring sections and two plates cut from these pieces.

The vessel segments included both fracture surfaces, the field weld joining Courses 2 and 3, and samples of the original construction welds joining Courses 3, 4, and 5. Inspection of these pieces revealed:

1. Indications of several hundred cracks in the vicinity of the field welds joining Course 2 to the vessel by MPI

2. Few indications of cracks in the vicinity of the original fabrication welds or near the vertical field welds within Course 2

3. Numerous indications of delamination in Course 1 by ultrasonic inspection

4. No clear indications of delamination in either Course 2 or Course 3 by ultrasonic inspection

5. No significant reduction in the thickness of the vessel due to corrosion in the vicinity of the fracture 
MATERIALS EVALUATION

A series of tests was conducted on the steel plates and welds of pressure vessel 12D701. The purpose of these tests was to characterize the materials of construction.

\section{Chemical Analysis}

The chemical compositions of the steel plates used for courses 1, 2, and 3 of Welds $1 / 2,2 / 3$, and of vertical Weld $A$ in Course 2 were determined by atomic emission spectroscopy. The procedures were in accordance with ASTM E 415 [3]. The vacuum spectrometer was calibrated for the runs using NBS Standard Reference Materials 1261-65, 1161, 1162, 1164, 1222, 1227, 1134 , 1136, C1173, 1139a, 33d, 36b, 55e, 10g, 1218 and Reference Materials 50b, and BAS 405 .

The results for the steel plates are presented in Table I along with the chemical requirements specified for ASTM A516 Grade 70. All three plates met the specified requirements. The compositions of courses 1 and 3 were essentially the same, suggesting that both plates came from the same heat. The composition of Course 2 differs, as expected, since the Course 2 steel was from a different heat. The principal difference between the heats is that the course 1 and 3 steel had significantly higher sulfur $(0.028 \%$ vs. $0.017 \%)$ and aluminum (0.08\% vs. 0.05\%) contents. Sulfur and aluminum are inclusion formers, and thus the cleanliness of Course 2 steel was likely to be superior to that of the steel for Courses 1 and 3 .

The results for the welds are also presented in Table I along with chemical requirements specified for AWS E7018 welds. All the welds met the requirements specified for AWS E7018. The carbon, manganese, and silicon contents are typical for these welds. The samples taken from Weld $2 / 3$ and the vertical weld were analyzed twice. The small variations in the measured values were with in the range expected for welds.

\section{Tensile Properties}

The tensile properties of the steel plates used for courses 1,2, and 3 and of Weld $1 / 2$ were measured using the procedures of ASTM E 8 [4]. TWO tests on each material were conducted at room temperature, and $0.2 \%$ offset 


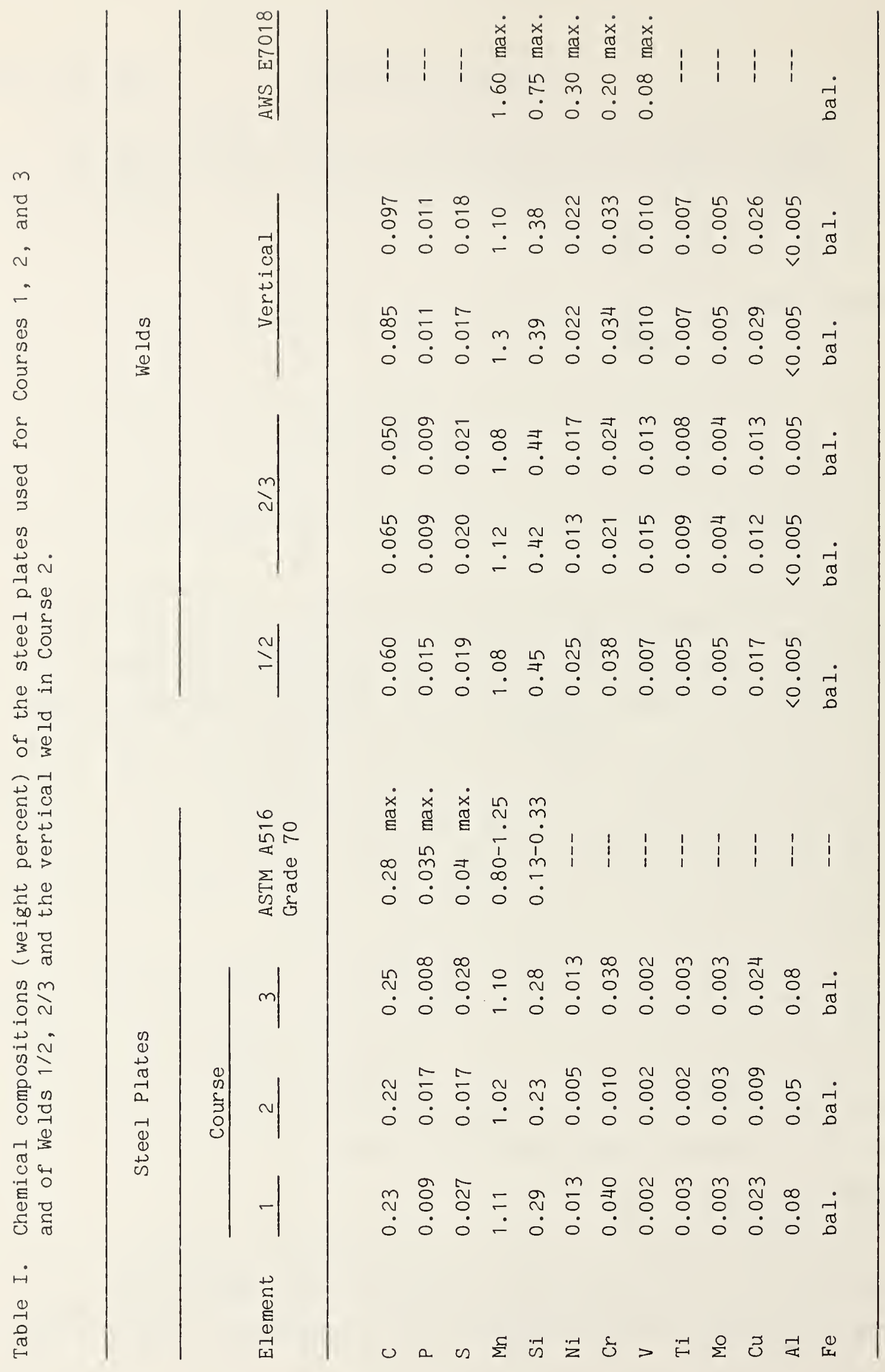


yleld strength, ultimate tensile strength, percent elongation, and percent reduction of area were measured. The plate properties were measured with $50 \mathrm{~mm}$ (2 in.) gage length, $12.7 \mathrm{~mm}$ ( $0.5 \mathrm{in.}$ ) diameter specimens taken from the midthickness level of the plate and oriented in the transverse direction. The weld properties were measured with $25 \mathrm{~mm}$ ( 1 in.) gage length, $6.4 \mathrm{~mm}$ (0.25 in.) diameter specimens taken along the length of the weld such that the entire test section was in the weld.

The results are presented in Table II along with the tensile requirements specified for ASTM A516 Grade 70 and AWS E7018. The steel plates and weld metal exceed their respective tensile requirements. The tensile properties of the plates are essentially the same, and the yield strength of the weld metal ( $477 \mathrm{MPa}, 69.2 \mathrm{ksi}$ ) is significantly greater than that of the plate ( $300 \mathrm{MPa}, 43.5 \mathrm{ksi}$ ).

\section{Charpy Impact Toughness}

The Charpy impact toughness was measured as a function of temperature on specimens taken from Courses 1 and 2, Weld 2/3, and $\mathrm{HAZ} 2$ of Weld 2/3. The tests were conducted in a $165 \mathrm{~J}$ (122 ft.lbf) capacity impact machine in accordance with the procedures of ASTM E 23 [5]. The specimen configuration and the notch locations are shown in Figure 8 . The notches were oriented perpendicular to the plate surface such that the fracture of the plate specimens proceeded in the rolling direction (TL orientation), and the fracture of the weld metal and HAZ specimens proceeded along the length of the weld. Test temperatures of $38,0,-40$, and $-51^{\circ} \mathrm{C}\left(100,32,-40\right.$, and $\left.-60^{\circ} \mathrm{F}\right)$ were selected to cover the range of the ductile-to-brittle transition and to permit estimation of the $20 \mathrm{~J}$ (15 ft•lbf) Charpy V-notch transition temperature.

The results are presented in Table III. The weld metal and HAZ toughness exceeded that of the base metal. The estimated $20 \mathrm{~J}$ ( $15 \mathrm{ft} \cdot \mathrm{lbf}$ ) transition temperatures were $0^{\circ} \mathrm{C}\left(32^{\circ} \mathrm{F}\right.$ ) for the base metal (Courses 1 and 2 ), $-51^{\circ} \mathrm{C}$ $\left(-60^{\circ} \mathrm{F}\right.$ ) for the weld metal (Weld $2 / 3$ ), and $-40^{\circ} \mathrm{C}\left(-40^{\circ} \mathrm{F}\right.$ ) for the HAZ of Course 2 . 


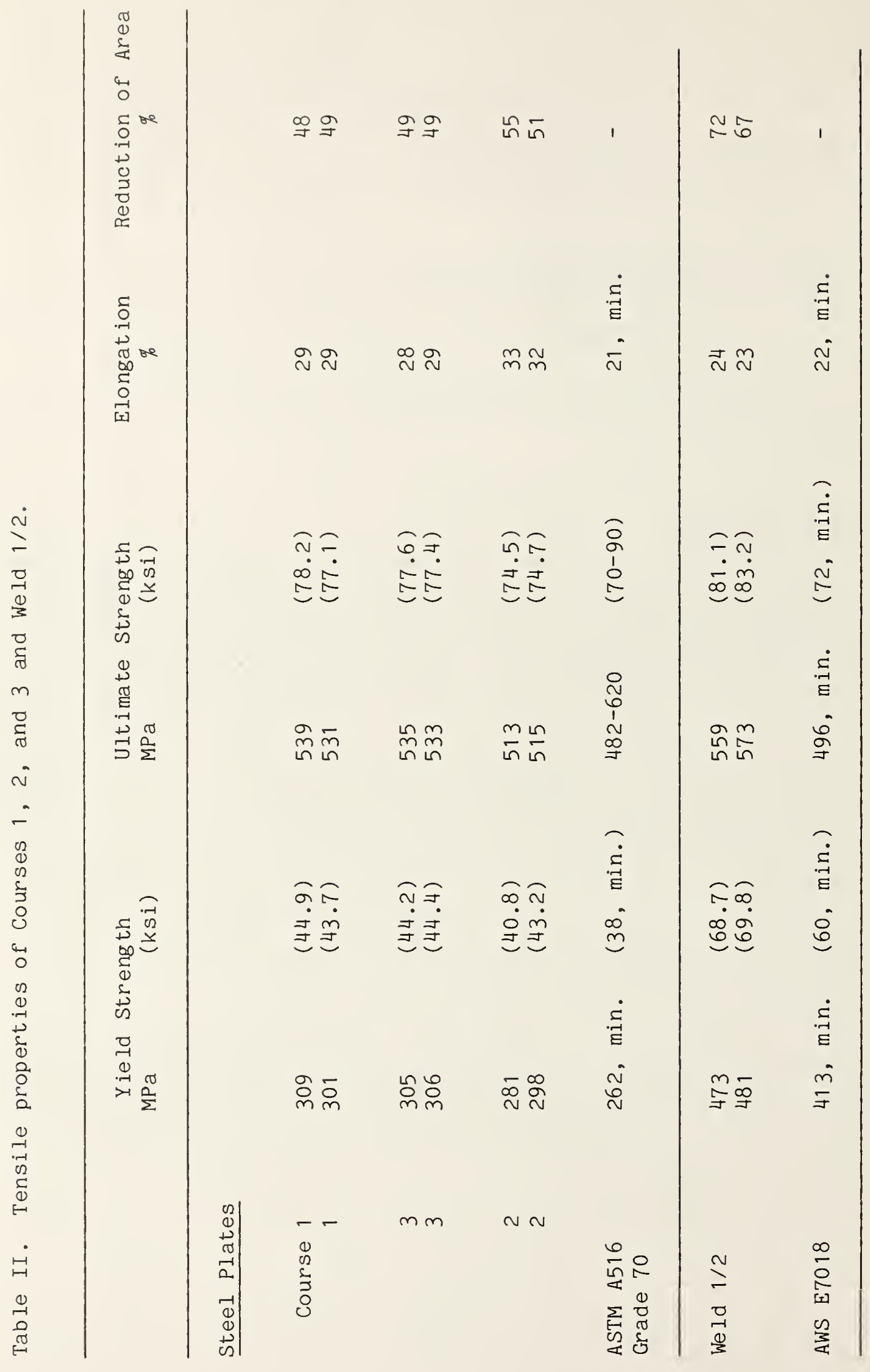




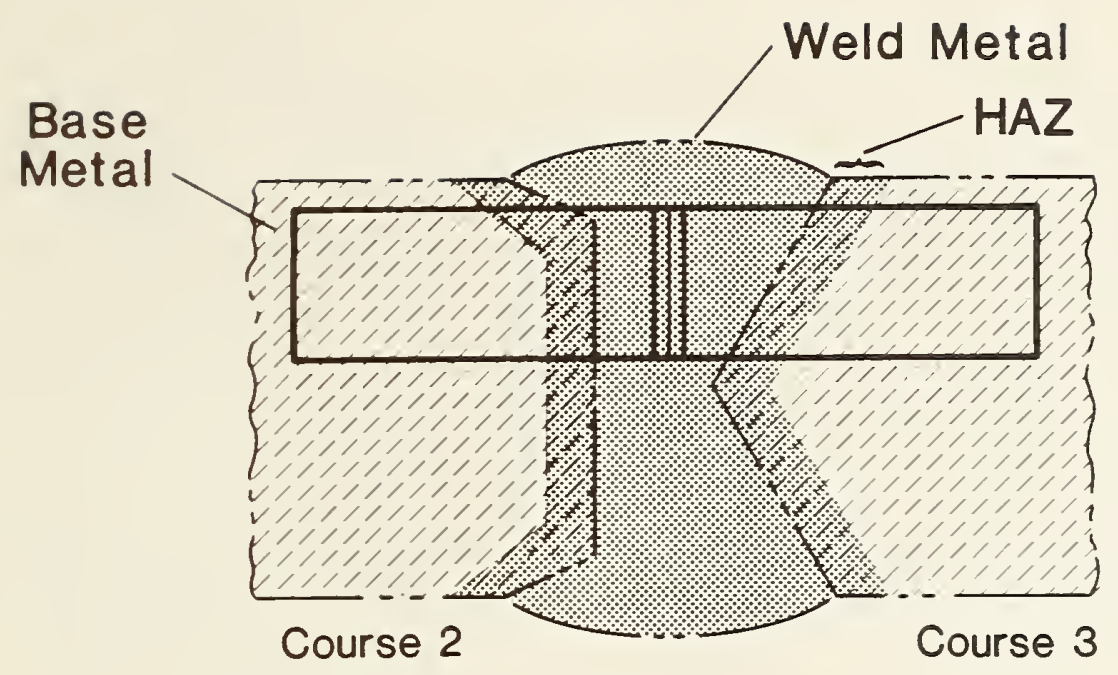

\section{Weld Metal Charpy}

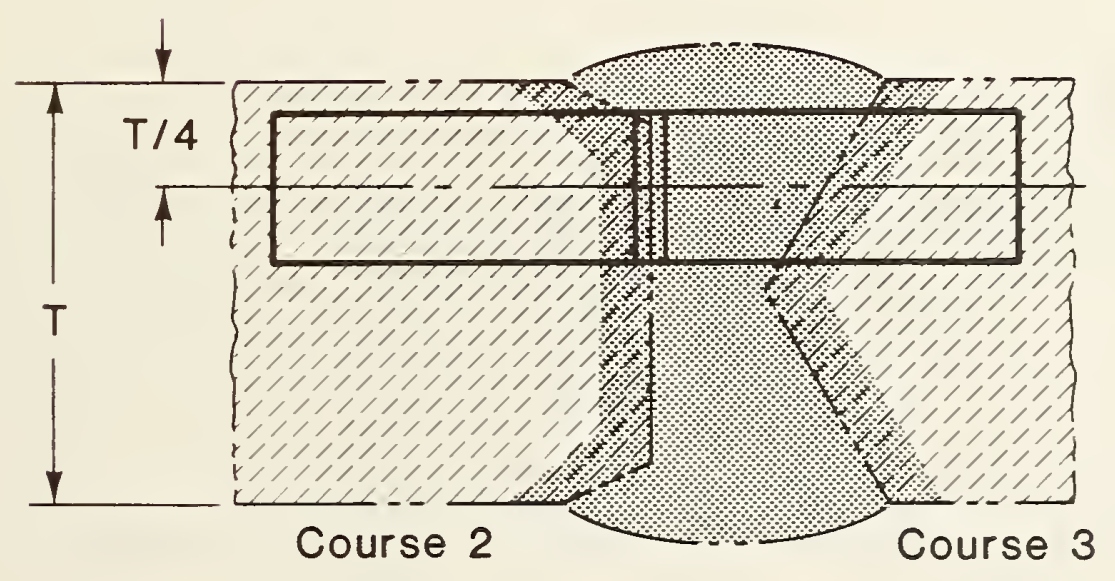

\section{HAZ 2 Charpy}

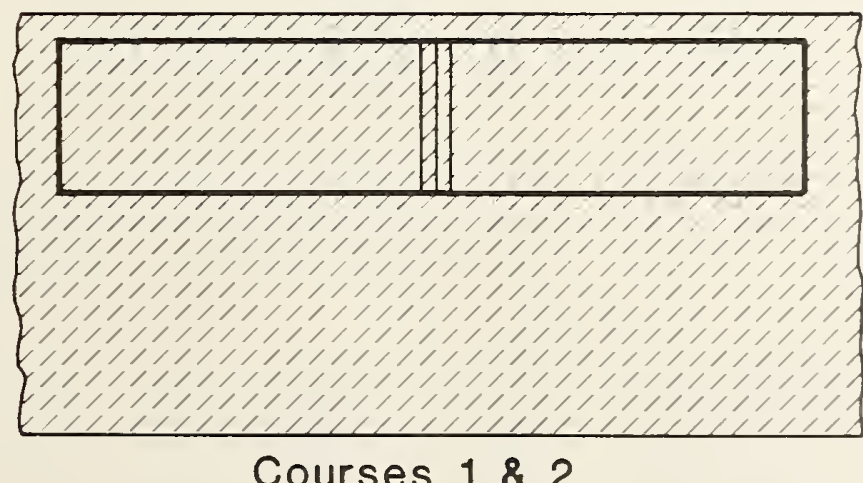

Base Metal Charpy

Figure 8. Charpy specimens and their notch locations. 


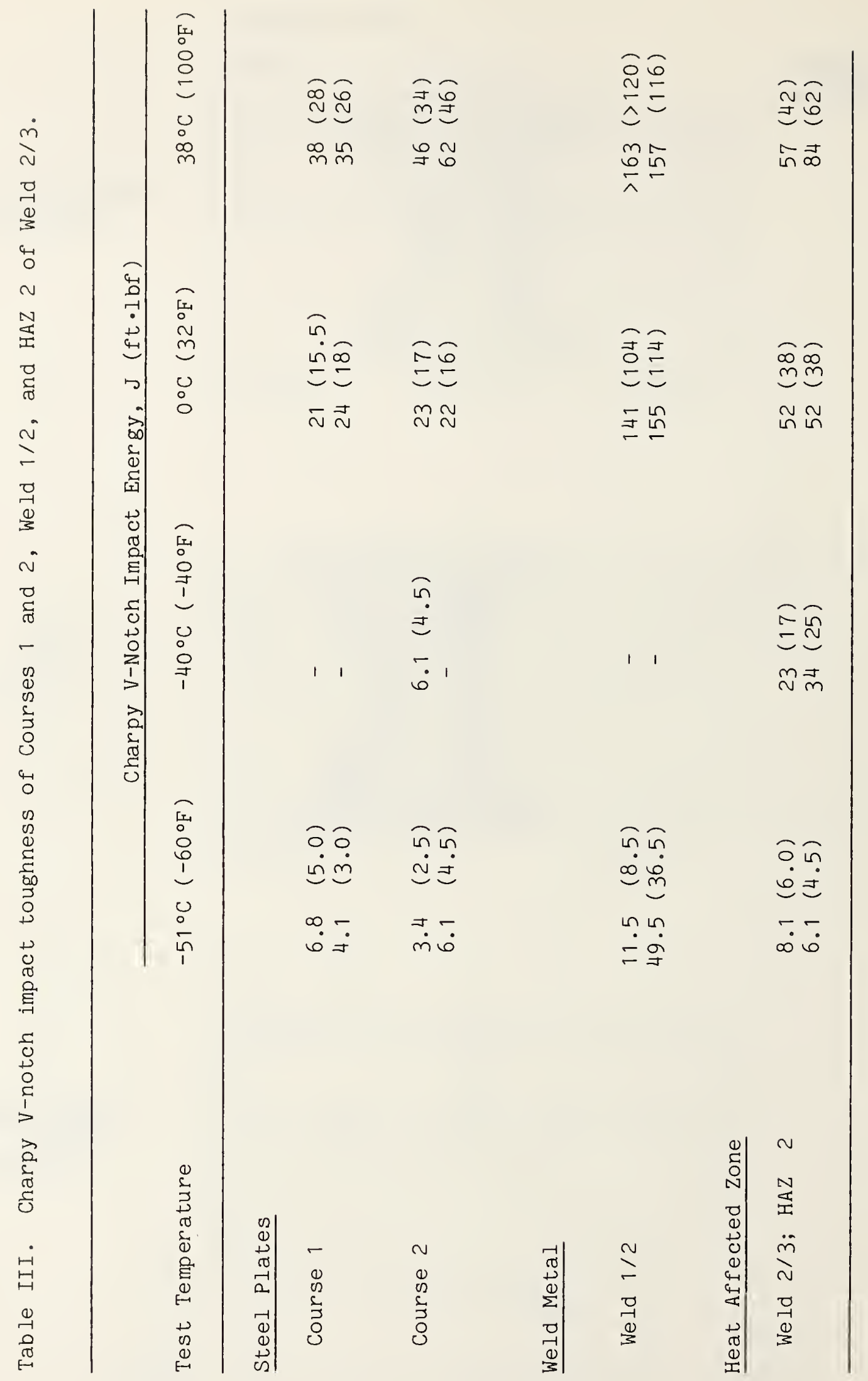


Fracture toughness was measured by the crack tip opening displacement (CTOD) method as a function of temperature on specimens taken from Ring 3. The tests were conducted in accordance with BS 5762 [6], "Methods for Crack Opening Displacement Testing" using full-thickness (to the extent practical), single-edge-notch-bend (SENB) specimens. The specimens, shown in Figure 9 , were $50 \mathrm{~mm}$ (2 in.) wide and were tested in three-point bending over a $200 \mathrm{~mm}$ ( 8 in.) span. The specimens were in the TL orientation, i.e., the crack was perpendicular to the plate surface and parallel to the weld.

Before the notches were machined, the specimens were etched to reveal the HAZ. The notch location was scribed on the specimen as shown in Figure 10a. The notches were typically located in the HAZ, as shown in Figure $10 \mathrm{~b}$ on the Course 2 side of Weld $2 / 3$. This side had a straighter HAZ than the Course 3 side because course 2 was the lower side of Weld $2 / 3$. In the horizontal welding used to replace Course 2, the lower course served as a shelf to build up the weld and the upper course had a double bevel preparation. Two specimens were notched on the Course 3 side of the weld to spot check the toughness values of the Course $3 \mathrm{HAZ}$.

Before fatigue precracking, the specimens were given a precompression treatment to ensure a straight crack front [7]. A compressive strain of $1 \%$ was applied to the crack tip region in the through-thickness direction. The specimen was squeezed between two $19 \mathrm{~mm}$ (0.74 in.) diameter disks centered in the notch plane $9 \mathrm{~mm}$ ( $0.35 \mathrm{in.})$ ahead of the notch tip. A specimen with the indentations due to precompression is shown in Figure $10 \mathrm{c}$. After precompression, the specimens were precracked in fatigue at room temperature. The typical length of fatigue extension was $2 \mathrm{~mm}(0.08 \mathrm{in.})$ resulting in a total crack length of $25 \mathrm{~mm}$ (0.98 in.).

The specimens were tested in a servohydraulic testing machine with a $100 \mathrm{kN}\left(22,000 \mathrm{lbf}\right.$ ) capacity. Tests were conducted at 38,0 , and $-40^{\circ} \mathrm{C}$ $(100,32$, and $-40 \% \mathrm{~F})$. These temperatures were selected to represent the range of temperatures possible at the crack tip at the time of the incident. The service temperature was $38^{\circ} \mathrm{C}\left(100^{\circ} \mathrm{F}\right)$. The temperature of $-40^{\circ} \mathrm{C}\left(-40^{\circ} \mathrm{F}\right)$ could have occurred due to the cooling effect of evaporating propane, which was leaking through the crack just prior to the failure. The temperature of $0^{\circ} \mathrm{C}$ $\left(32^{\circ} \mathrm{F}\right)$ was simply an intermediate temperature. 


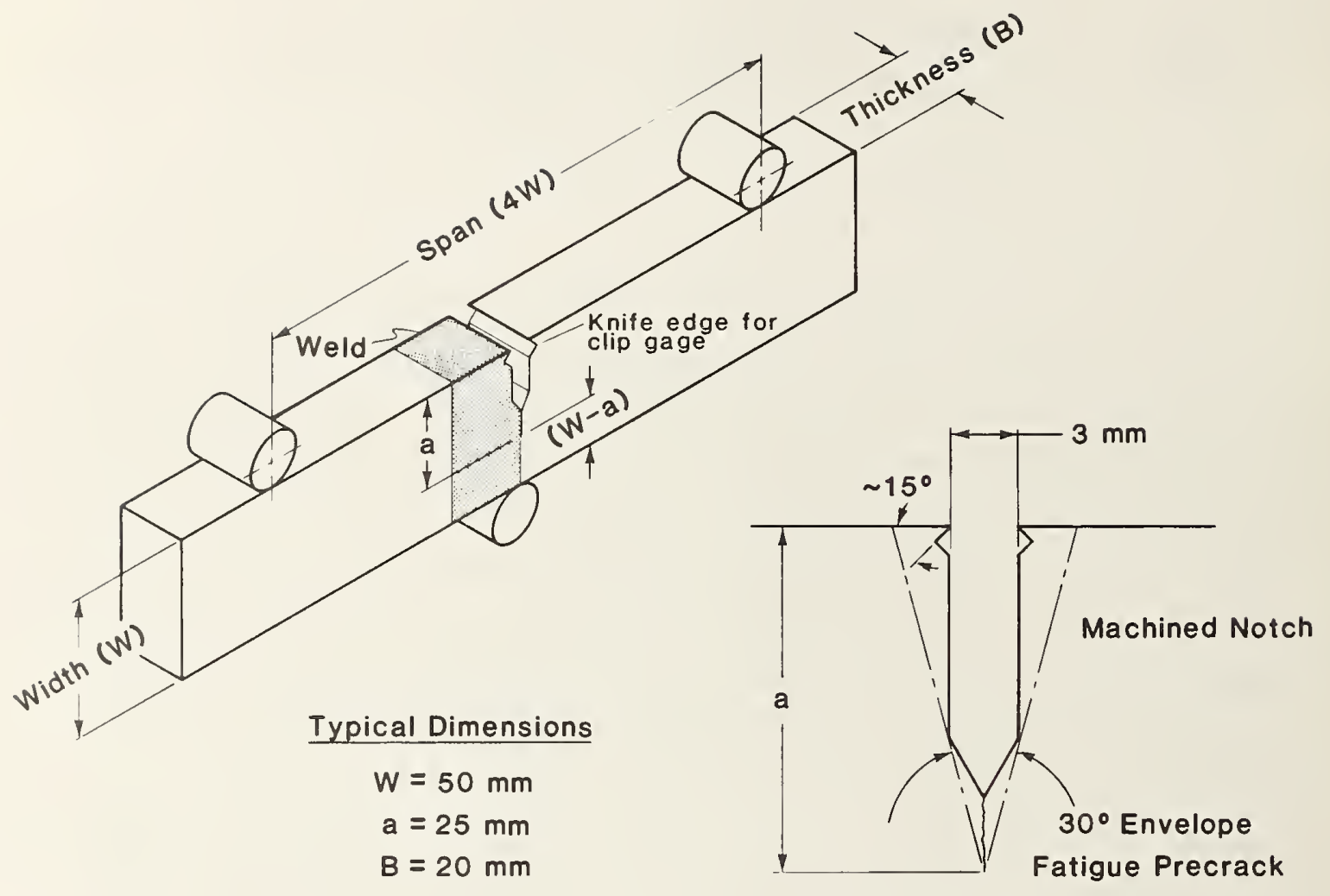

Figure 9. Single-edge-notch-bend specimens for fracture toughness testing. 

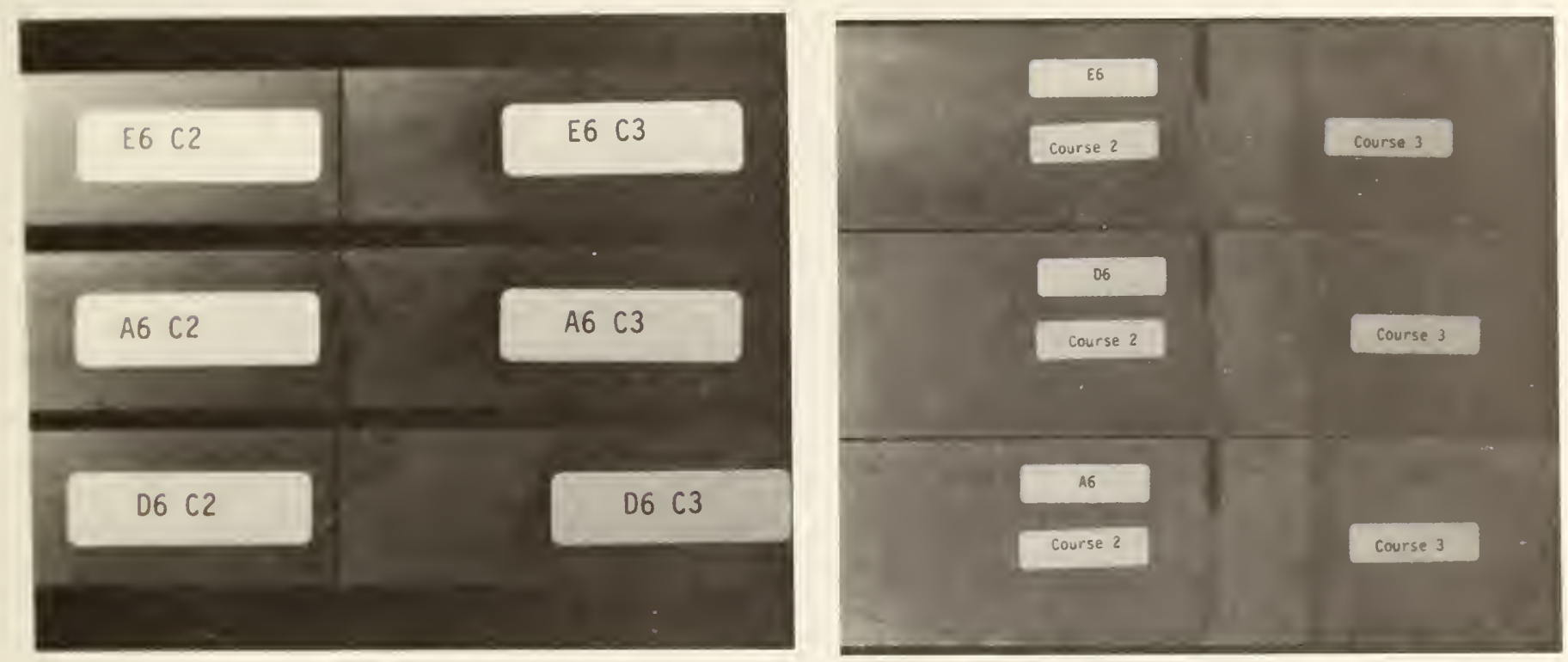

a. Scribe line to locate notch

b. Specimens after notching
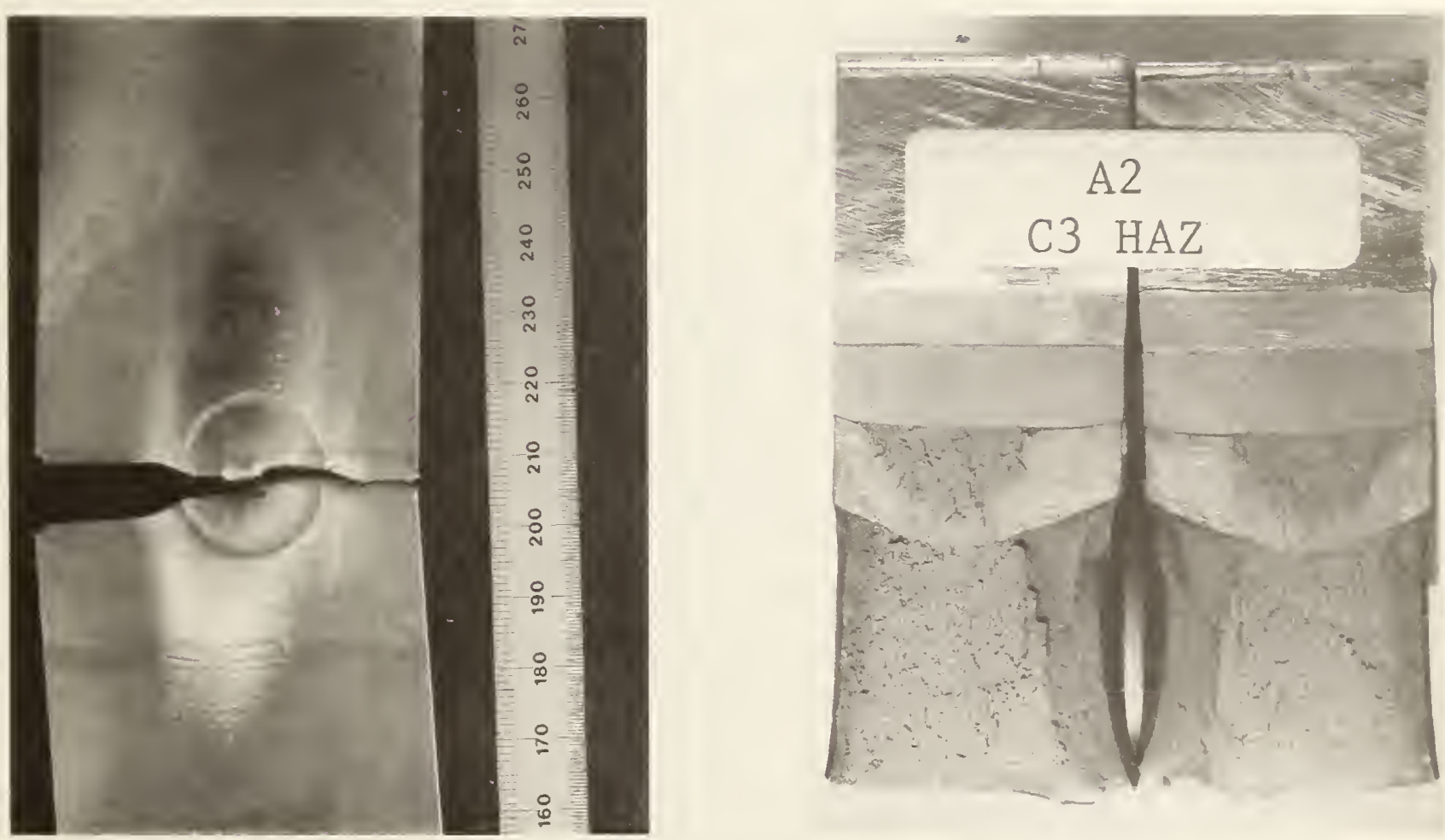

c. Specimen after testing showing region of precompression.

d. Fracture surface of specimen tested at $38^{\circ} \mathrm{C}\left(100^{\circ} \mathrm{F}\right)$

Figure 10. Notches in fracture toughness specimens. 
The results of the fracture toughness tests are summarized in Table IV. The scatter in the results was due in part to variations in the notch locations with respect to the weld. The weld metal toughness was higher than the base metal or HAZ toughness. Thus, if the crack front was partially located in the weld, higher values were measured. The specimens were notched in groups so that the test results for one group of tests could be reviewed and before notching the next group. Owing to the toughening effect of the weld, the notches in later tests were moved farther away from the weld metal. This tended to reduce the scatter in the later tests conducted at $38^{\circ} \mathrm{C}$ $\left(100^{\circ} \mathrm{F}\right)$, i.e., specimens identified as A2, C2, and C5 in Table IV.

\section{Rockwell Hardness}

Rockwell hardness traverses were taken on cross sections of Welds $1 / 2$, $2 / 3,3 / 4$, and 4/5, and the vertical welds in Courses 1,2 (Welds $A, B$, and $C$ ), 3, and 5. The traverses were nominally parallel to the plate surface. Each traverse sampled the hardness of the weld, the base metal, and the HAZ on each side of the weld. The Rockwell scale (HRA) was used for all specimens, and the Rockwell B scale (HRB) was also used for Weld A in Course 2 and for weld $2 / 3$.

The results of the Rockwell hardness traverses are presented in Appendix D. In general, the hardnesses of the base metal, HAZ, and weld metal were uniform, indicating an appropriate matching of the tensile strengths of the base metal and the weld. The peak hardness in the HAZ of all but one of the specimens was within 2 HRA points of the peak hardness in the weld. The one exception was the HRB traverse on Weld $2 / 3$, where the peak hardness in the HAZ was $106 \mathrm{HRB}$ compared with a peak of $98 \mathrm{HRB}$ in the weld. The possibility of high hardness values in the repair welds done to replace Course 2 was studied further by measuring microhardness.

\section{Metallography and Microhardness}

The metallography to evaluate the steel and welds of pressure vessel 12 D701 discussed in this section includes: 1) sections through welds $1 / 2$ and $2 / 3$ and through a vertical weld in Course 2 showing the microstructures of the weld, HAZ, and base metal; 2) a section through weld $1 / 2$ showing the microstructure near the Monel-to-steel weld and surface-breaking cracks in the base metal; and 3) longitudinal and transverse sections through a 


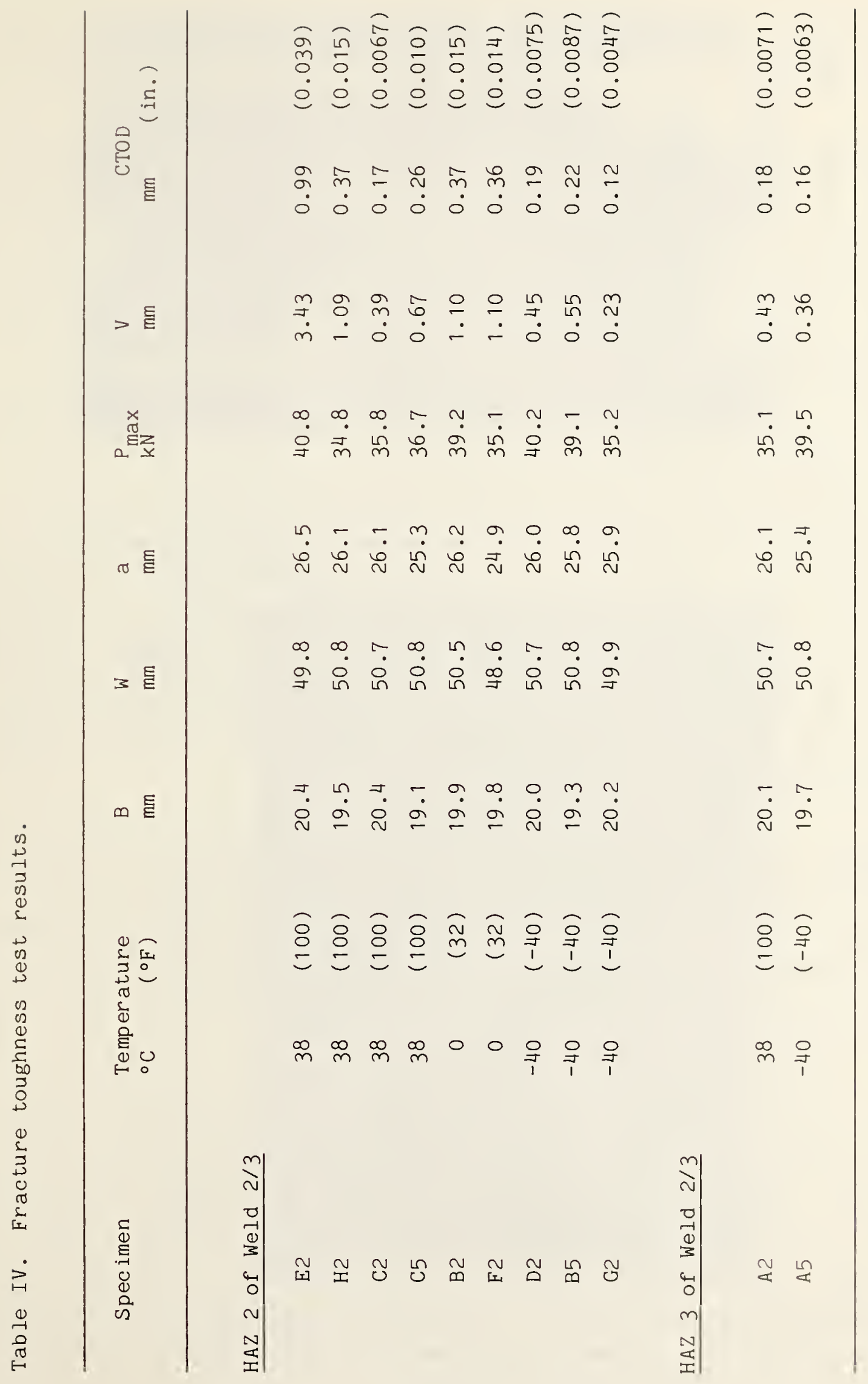


delaminated section of Course 1. Microhardness measurements were used to evaluate HAZ hardness and to assist in identifying microstructures.

Weld 1/2: The section through Weld 1/2, shown in Figure 11, was taken from Ring 1 at CC $1.5 \mathrm{~m}$ in the region where the crack propagated through Course 2 away from the weld. The daub of black that can be seen on the course 1 side of the inner surface is a bead of Monel from the seam weld that joined the liner to the vessel. The crack on the Course 2 side of the inner surface ( $A$ in Figure 11) was stretched open, presumably at the time of $\mathrm{f}$ inal fracture. Apparently, the crack existed prior to the failure because the material on the weld side of the crack was not stretched, as revealed by the discontinuity in the HAZ.

The crack on the Course 1 side of the outer surface ( $B$ in Figure 11) initiated at the fusion line of the weld that joined Course 1 to the original Course 2. The large bead size of the weld adjacent to crack $B$ indicates that this is a submerged arc weld made during initial fabrication of the vessel that was not completely removed for the replacement of Course 2. The crack, shown at higher magnification in Figure 12, had a light etching corrosion product on the surface in contrast to the black deposits found in cracks on the inside surface.

Weld 2/3: A specimen was removed from the part of Ring 3 (CC $1.8 \mathrm{~m}$ ) where vertical weld $A$ in Course 2 intersected weld 2/3. The macrostructure of Weld 2/3, shown in Figure 13a, reveals the expected shape for a weld done in the horizontal position, i.e., a square lower edge (Course 2) and a V-shaped upper edge (Course 3). The sequence was to weld from the outside first and then complete the weld from the inside.

In the photograph of the HAZ 3 microstructure near the inside surface, Figure 13b, Weld $2 / 3$ is in the upper right, and the base metal of Course 3 is in the lower left. Within the HAZ, there is a coarse-grain region nearest the weld, then a fine-grain region, and finally, a partially transformed zone next to the base metal. The microstructure of the coarse-grain region, shown at higher magnification in Figure 13c, has the acicular appearance of martensite or martensite-bainite. The presence of martensite was also indicated by microhardness measurements taken near the inner surface in both HAZ 2 and HAZ 3. In both cases, the peak hardness values were in excess of 400 on the 


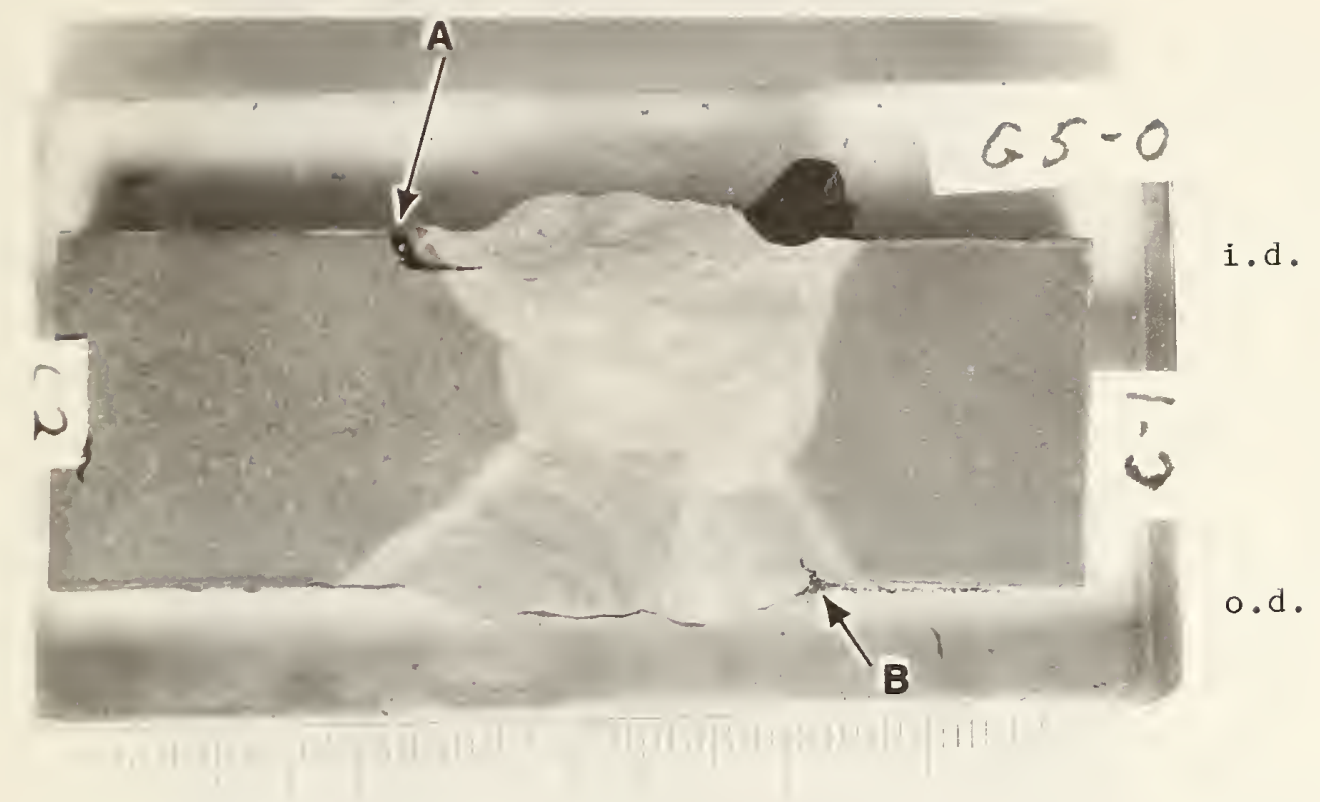

Figure 11. Macrostructure of Weld $1 / 2$ at CC $1.5 \mathrm{~m}$. Etchant: $2 \%$ nital

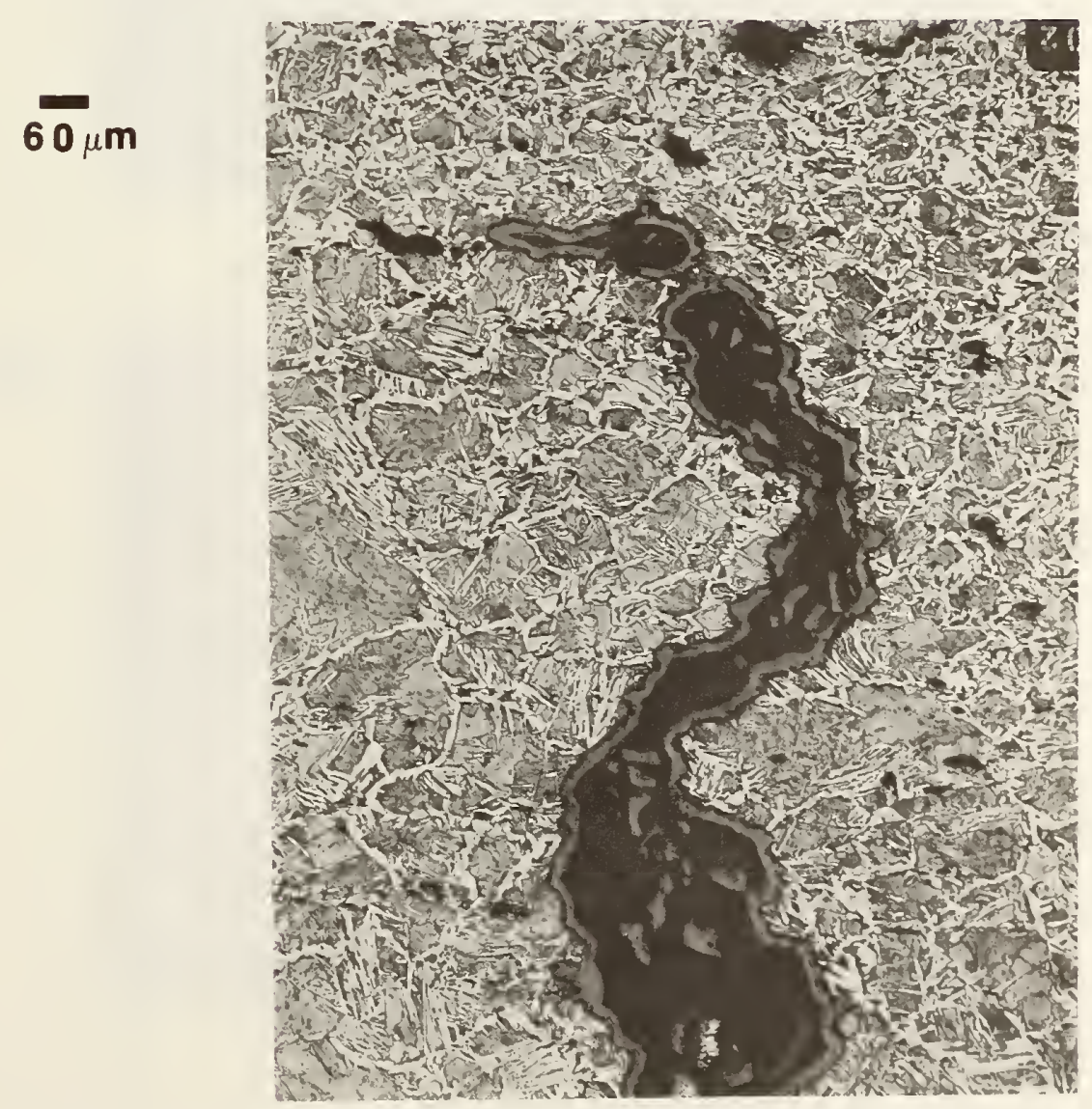

Figure 12. Microstructure near crack B in HAZ 1 shown in Figure 11. Etchant: $2 \%$ nital 


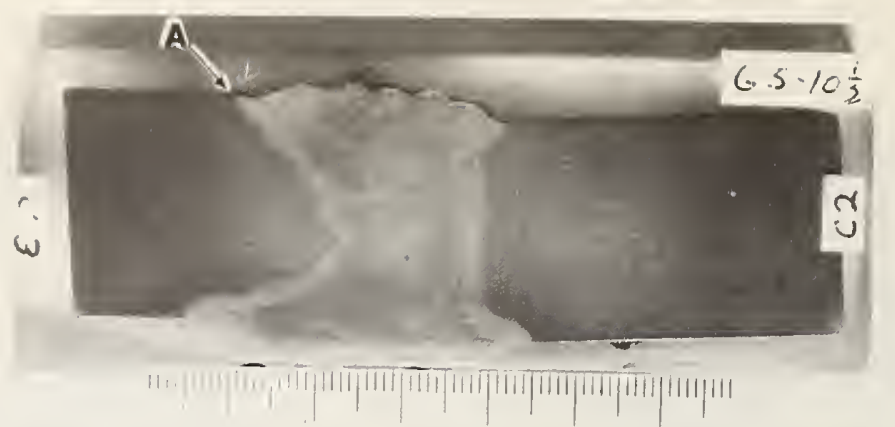

a. Macrostructure of Weld $2 / 3$ at CC $1.8 \mathrm{~m}$

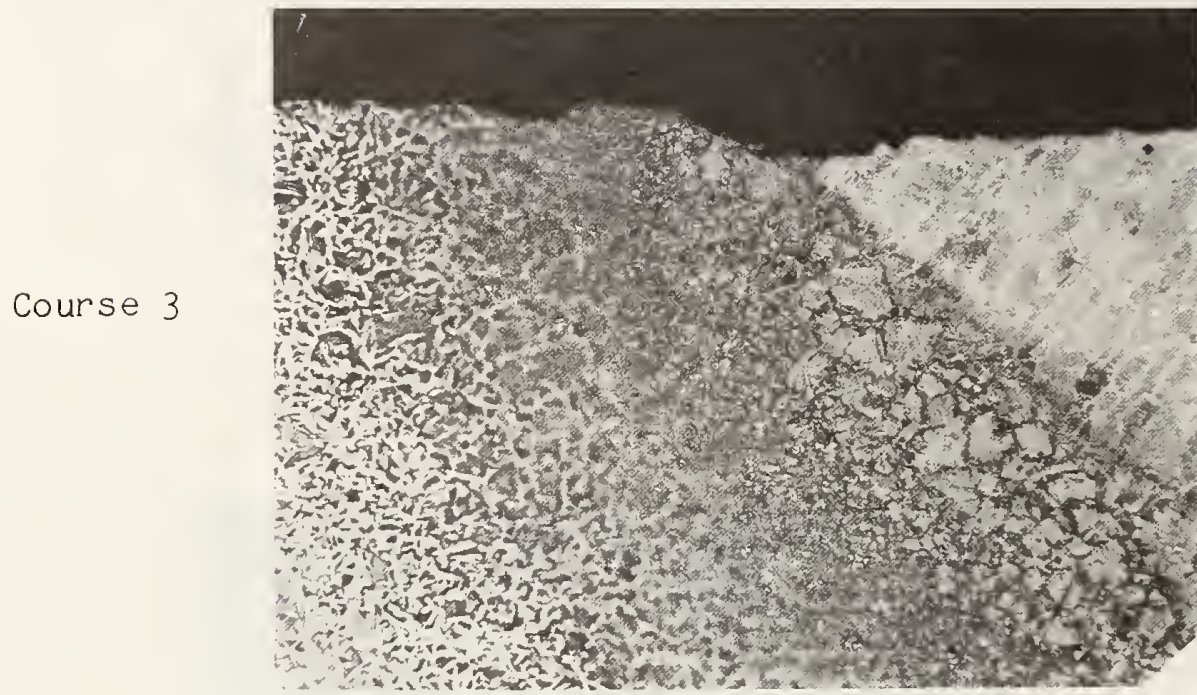

b. Macrostructure of HAZ 3

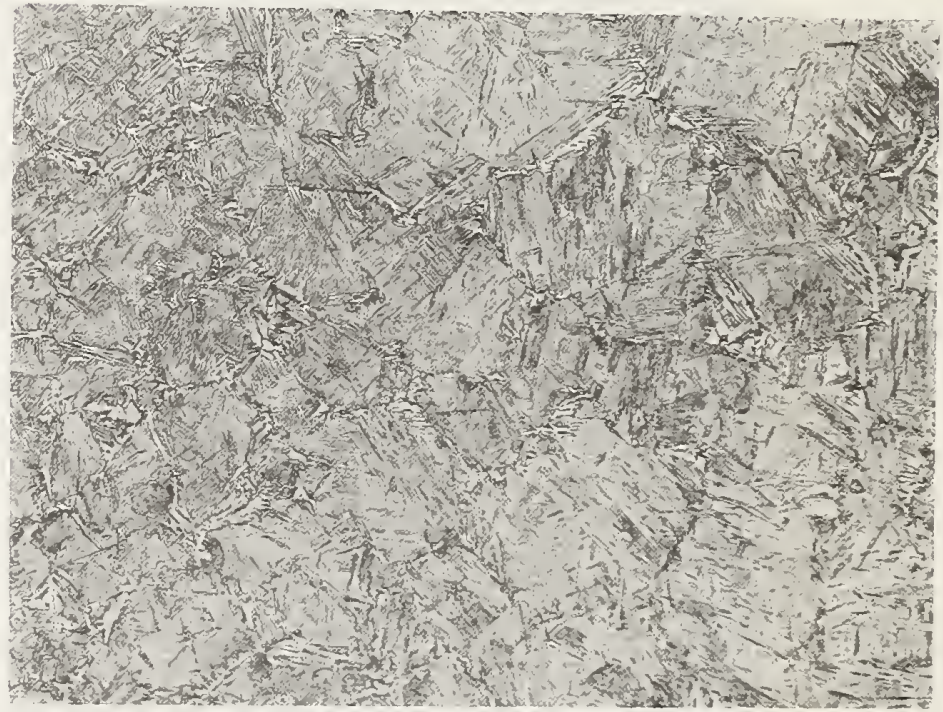

$25 \mu \mathrm{m}$

c. Microstructure of $\mathrm{HAZ} 3$

Figure 13. Macrostructure of Weld $2 / 3$ at CC $1.8 \mathrm{~m}$ and microstructure of HAZ 3. Etchant: $2 \%$ nital 
Knoop scale (HK). The results for HAZ 3 are shown in Figure 14. Figure $14 a$ shows the same location as Figure $14 \mathrm{~b}$ after making the hardness indentation. The values given in Figure $14 \mathrm{~b}$ are above $400 \mathrm{HK}$ in the coarse-grain region and over $300 \mathrm{HK}$ in the fine-grain region. The higher magnification photomicrograph, Figure $14 \mathrm{c}$, reveals martensite in the coarse-grain region of the HAZ. The martensite that formed adjacent to the plate surfaces was not tempered by subsequent weld passes. Microstructures containing hard martensite are known to be susceptible to hydrogen stress cracking.

Vertical Weld A, Course 2: The metallography of vertical Weld A in Course 2 is shown in Figure 15. This is a field weld made at the time course 2 was replaced. The weld was done in the vertical position, and as shown in Figure 15a, the joint preparation was symmetrical, and fewer weld passes were used to fill the joint than those used for the horizontal repair welds. The microstructure of the HAZ at the inside surface, shown in Figure 15b, does not show the coarse-grain region that can be seen in the horizontal repair weld in Figure 13b. This is because the microstructure in the coarse-grain region is ferrite and pearlite, as shown in Figure 15c, i.e., the same phases that exist in the other parts of the weldment. A microstructure of ferrite and pearlite is softer and more resistant to cracking than the martensite seen in the horizontal repair welds. Microhardness values in the HAZ ranged from 206 to $240 \mathrm{HK}$, as shown in Figure 16.

Monel-to-Steel Lap Weld: The specimen shown in Figure 17 was removed from Ring 2 (CC $1.0 \mathrm{~m}$ ) where the fracture path left a flap of Course 1 material containing the Monel-to-steel weld seam. This section also contained surface-breaking cracks (labeled A, B, and C in Figure 17a) in the base metal of course 2, which had previously been detected by MPI. As shown in Figures $17 \mathrm{~b}$ and $17 \mathrm{c}$, these cracks have a stepwise appearance typical of hydrogen pressure cracking. Crack C, shown at higher magnification in Figure $17 \mathrm{c}$, is connected to a delamination such that one appears to be an extension of the other. The specimen also shows a region of submerged arc welding near the outer surface of Course 1. Presumably, this was the weld that joined Course 1 and the original Course 2 and was not completely removed 

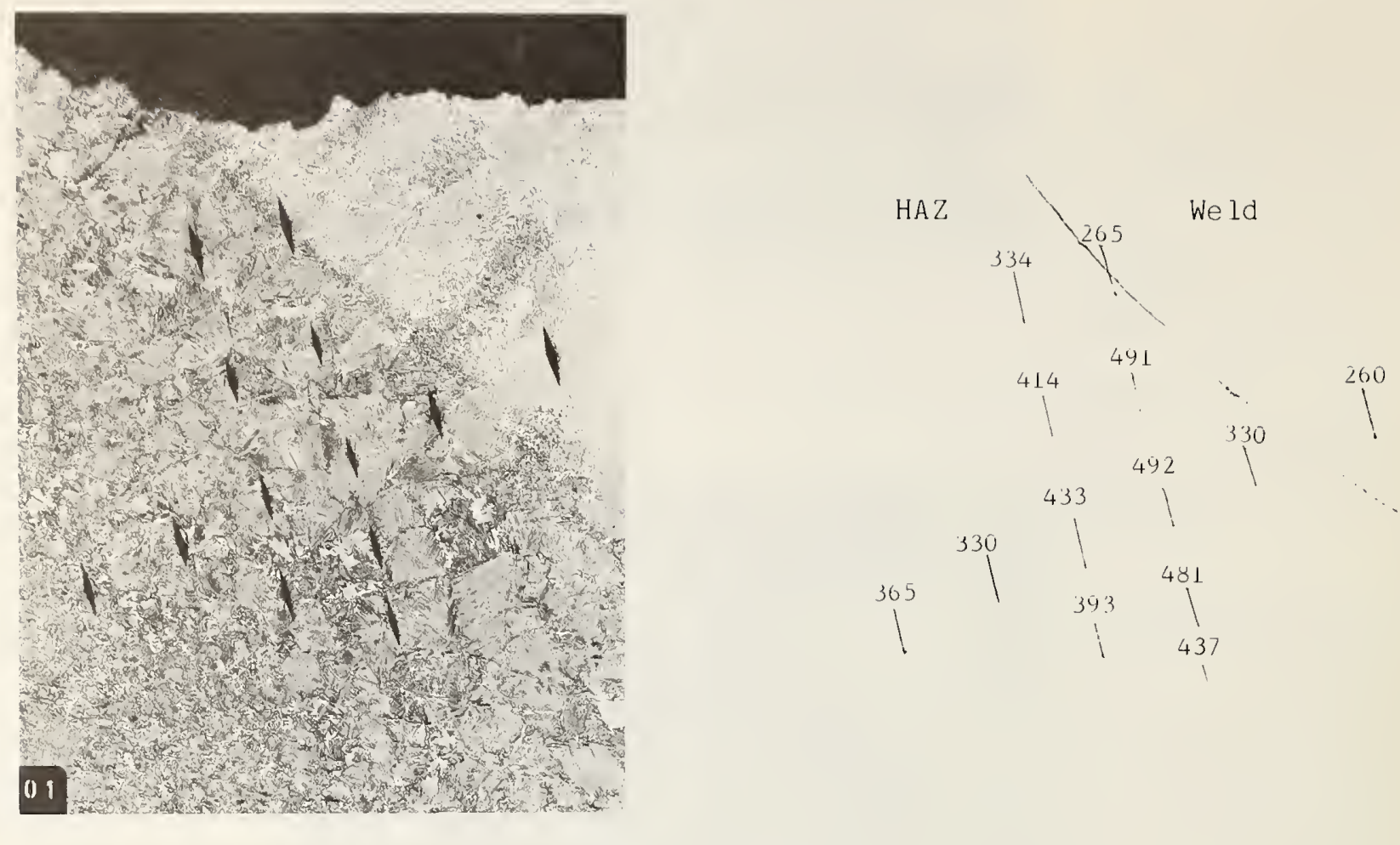
a. Knoop hardness indentations
b. Knoop hardness values (tracing of Fig. 14a)

$60 \mu \mathrm{m}$

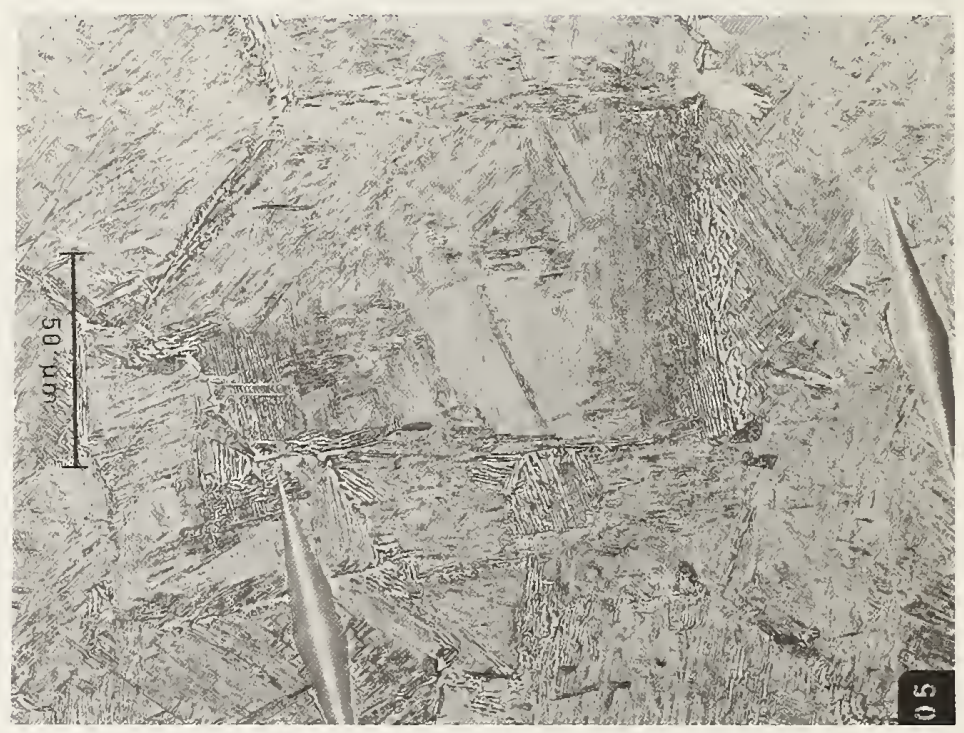

$20 \mu \mathrm{m}$

c. Microstructure at location of maximum hardness in Figure 14 a

Figure 14. Microhardness of HAZ 3 in Weld $2 / 3$ at CC $1.8 \mathrm{~m}$ at the location shown in Figure 13b. Etchant: $2 \%$ nital 


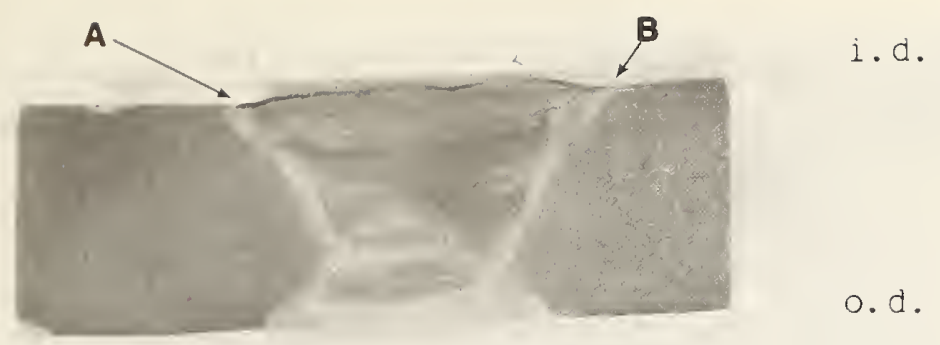

a. Macrostructure of vertical weld A in Course 2

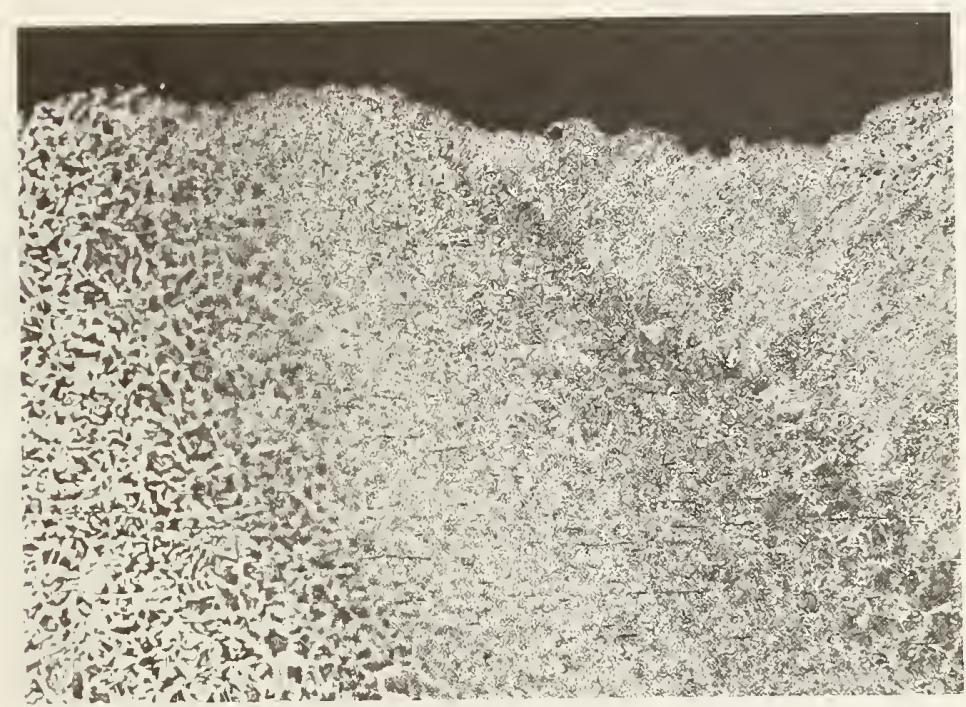

$0.25 \mathrm{~mm}$

b. Microstructure of HAZ at A in Figure $15 \mathrm{a}$

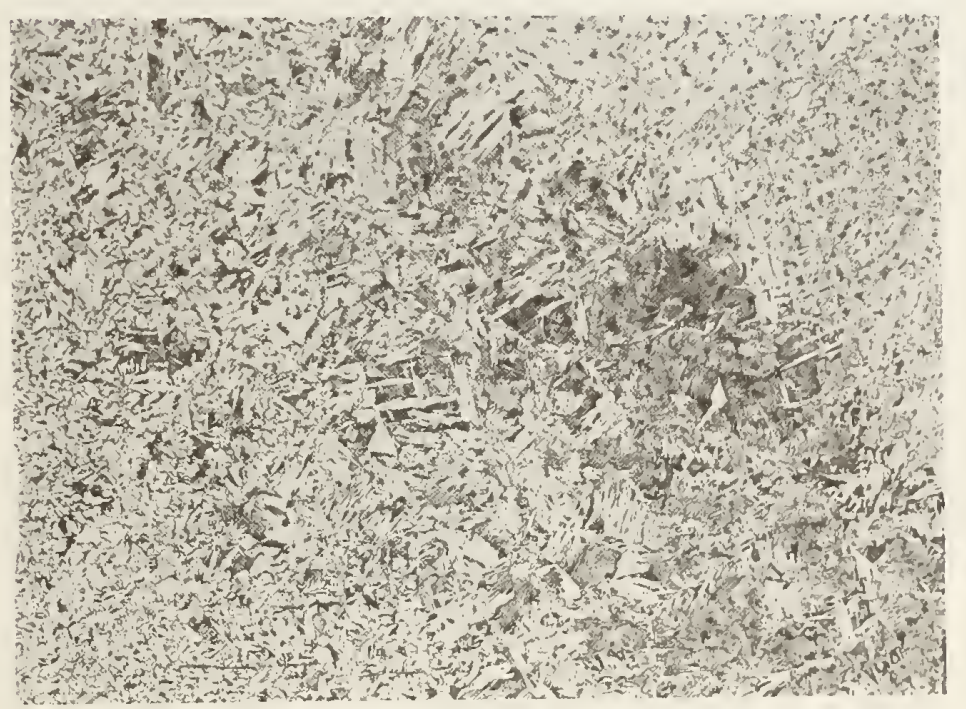

$25 \mu \mathrm{m}$

c. Microstructure of $\mathrm{HAZ}$

Figure 15. Macrostructure and microstructure of vertical weld $A$ in Course? Etchant: $2 \%$ nital 


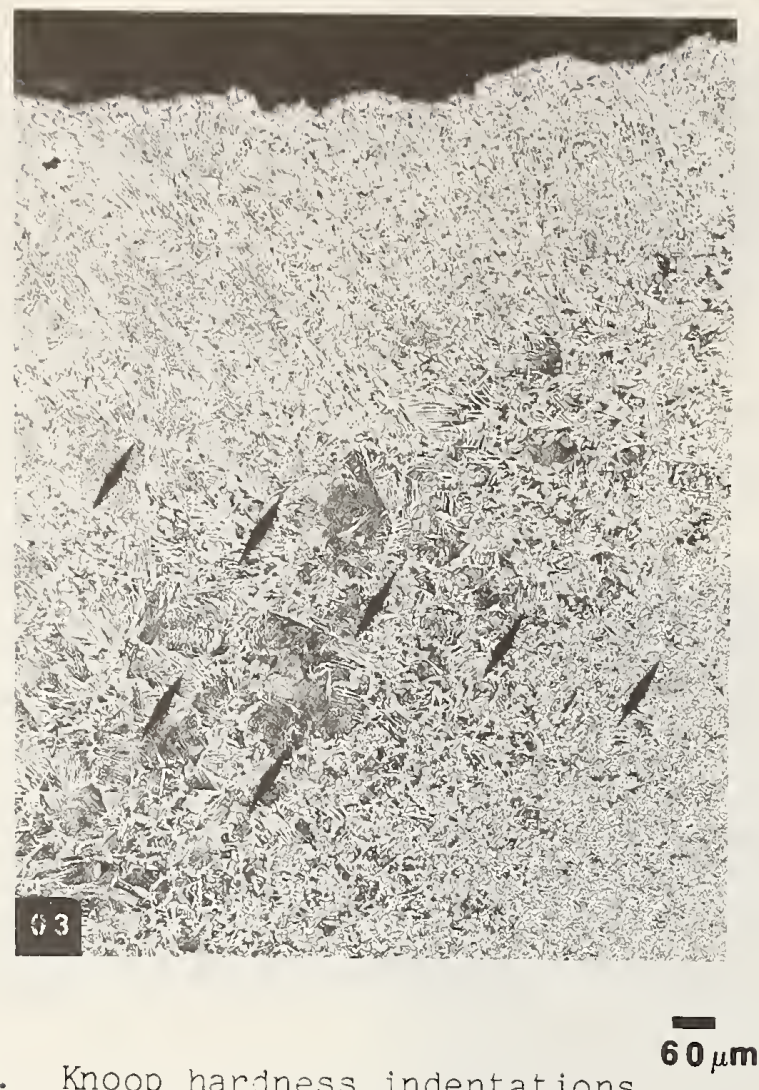

We $1 \mathrm{~d}$

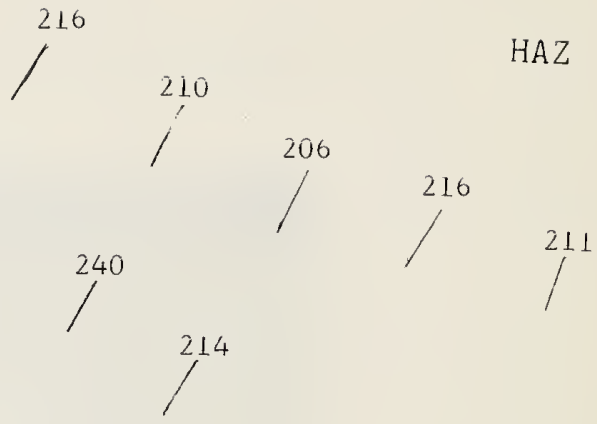

b. Knoop hardness values

(tracing of Fig. 16a)

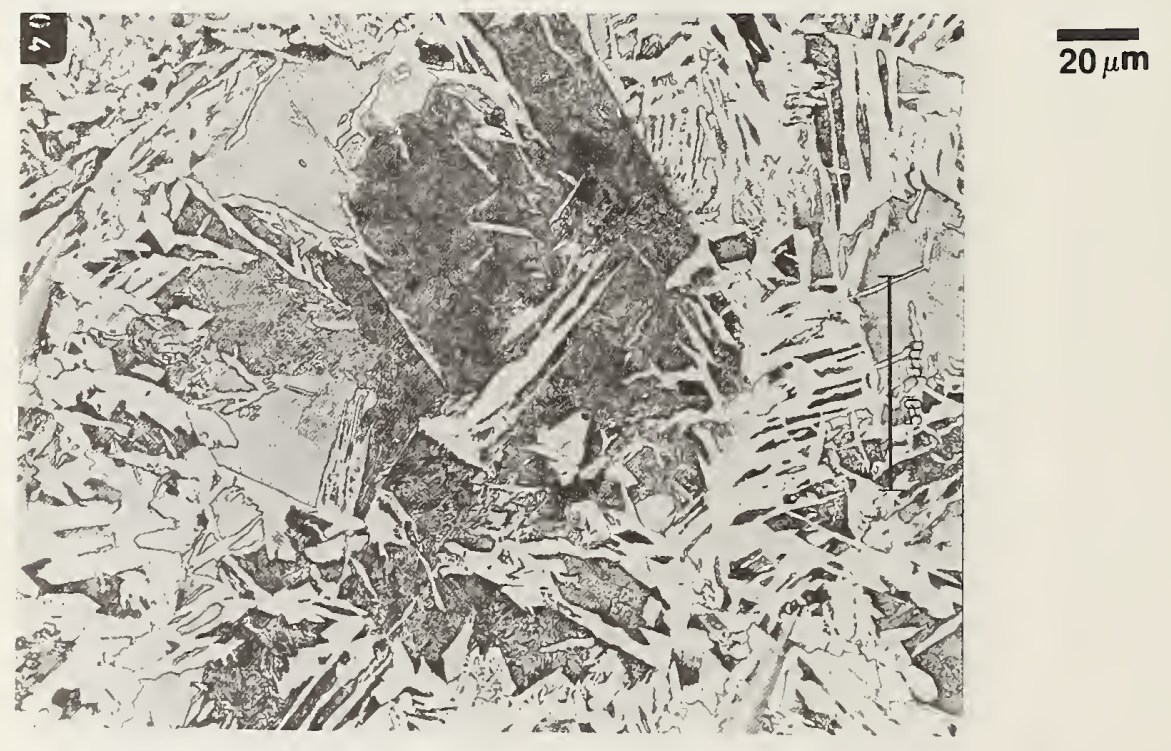

c. Microstructure of location of maximum hardness in Figure 16 a

Figure 16. Microhardness of vertical Weld $\mathrm{A}$ and its HAZ in Course 2 at location $B$ shown in Figure 15a. Etchant: 2\% nital 


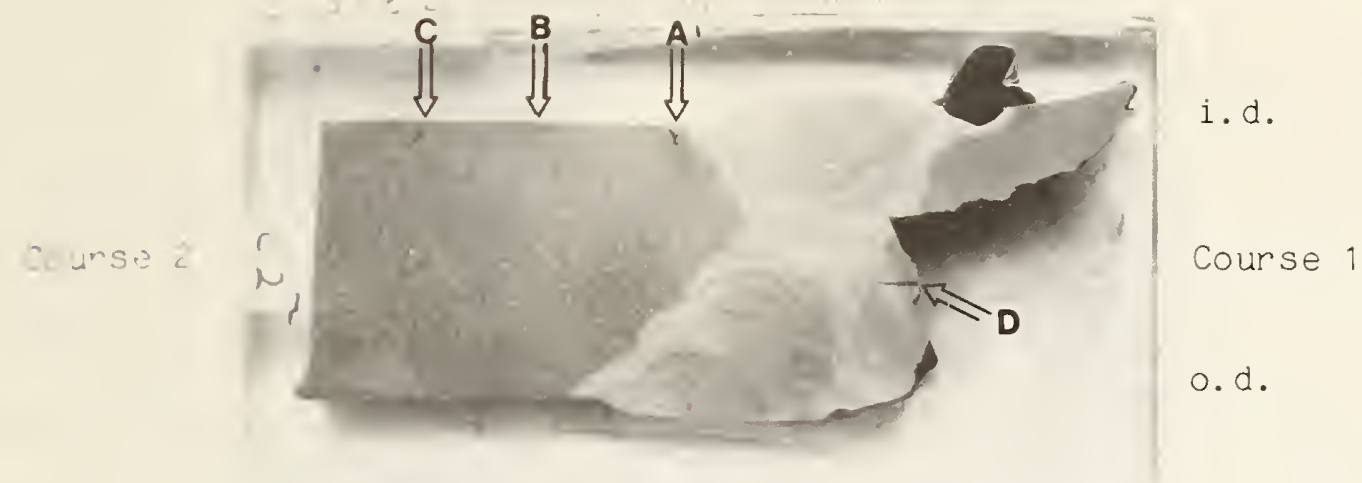

a. Macrostructure of Weld $1 / 2$ at CC 1.0 position

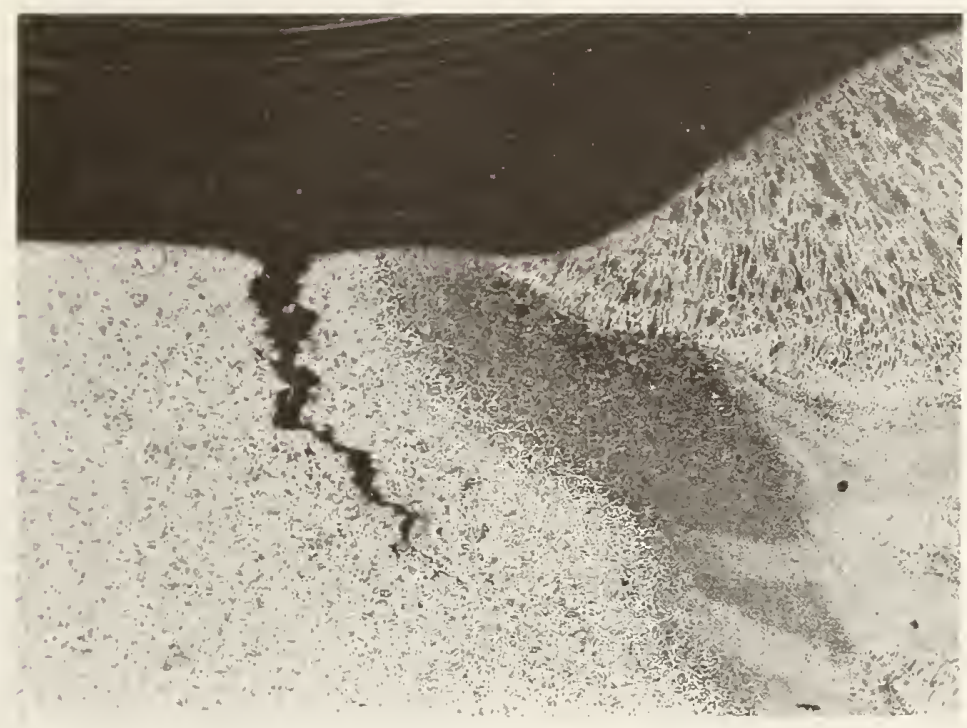

\section{$0.5 \mathrm{~mm}$}

b. Crack at location A in Figure 17 a

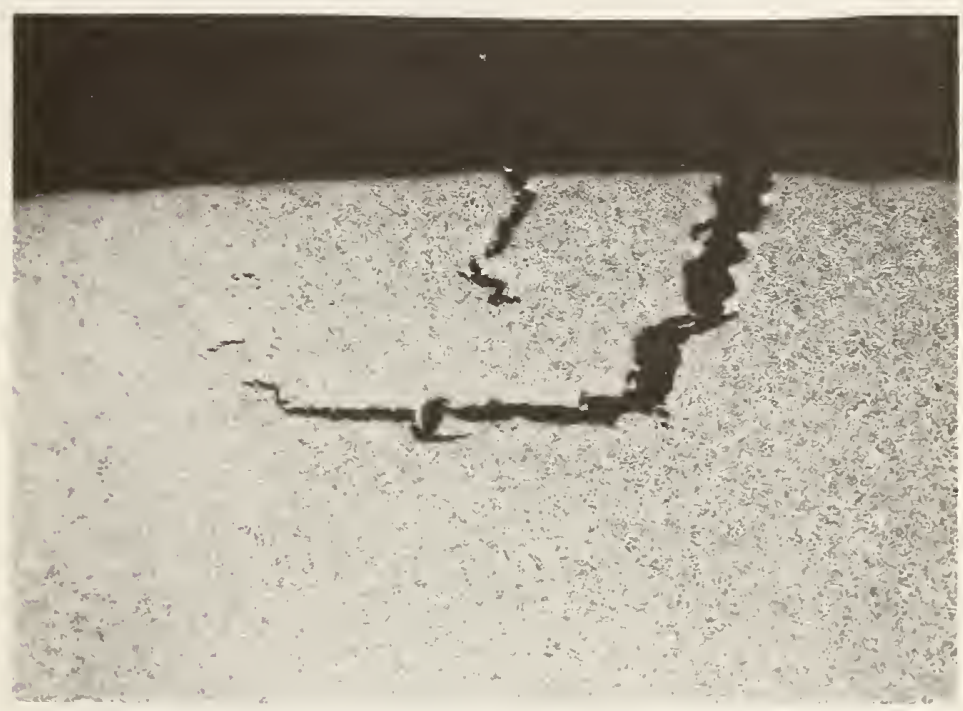

$0.5 \mathrm{~mm}$

c. Cracks at location C in Eigure 17 a

Eigure 17. Microstructure of weld $1 / 2$ at CC $1.0 \mathrm{~m}$ and base metal cracks on the inner surface of Course 2. Etchant: $2 \%$ nital 
at the time of the repair. Finally, there is a delamination in Course 1 labeled $D$ that terminates at the fusion line, as if it were unable to penetrate into the weld.

The microstructure on the steel side of the Monel-to-steel joint is shown in Figure 18. Monel that laps over onto Course 1 has apparently been eaten away by crevice corrosion, as shown in Figures $18 \mathrm{a}$ and $18 \mathrm{~b}$. This suggests that the Monel was locally anodic to the steel. This is contrary to what is expected on the basis of the position of these metals in the electromotive series. The microhardness indentations, Figures $18 \mathrm{~b}$ and $18 \mathrm{c}$, indicate hardness values of 479 and $497 \mathrm{HK}$ adjacent to the Monel. The microstructure at higher magnification, Figure $18 \mathrm{~d}$, shows that the $\mathrm{high}$ hardness values are due to the presence of martensite.

Delamination in Course 1: A sample was cut from Course 1 in an area where ultrasonic and magnetic particle inspection indicated delamination of the plate. Longitudinal and transverse sections through the sample are shown in Figures 19a and 19b, respectively. The transverse section is the view that would be observed in a section through a circumferential weld. At a higher magnification (Figure 19d), its appearance is similar to that observed on several metallographic samples and to a sketch (shown here as Figure 19c) of what is called "hydrogen-induced stepwise cracking" in NACE Standard TM-02-84 [7]. 


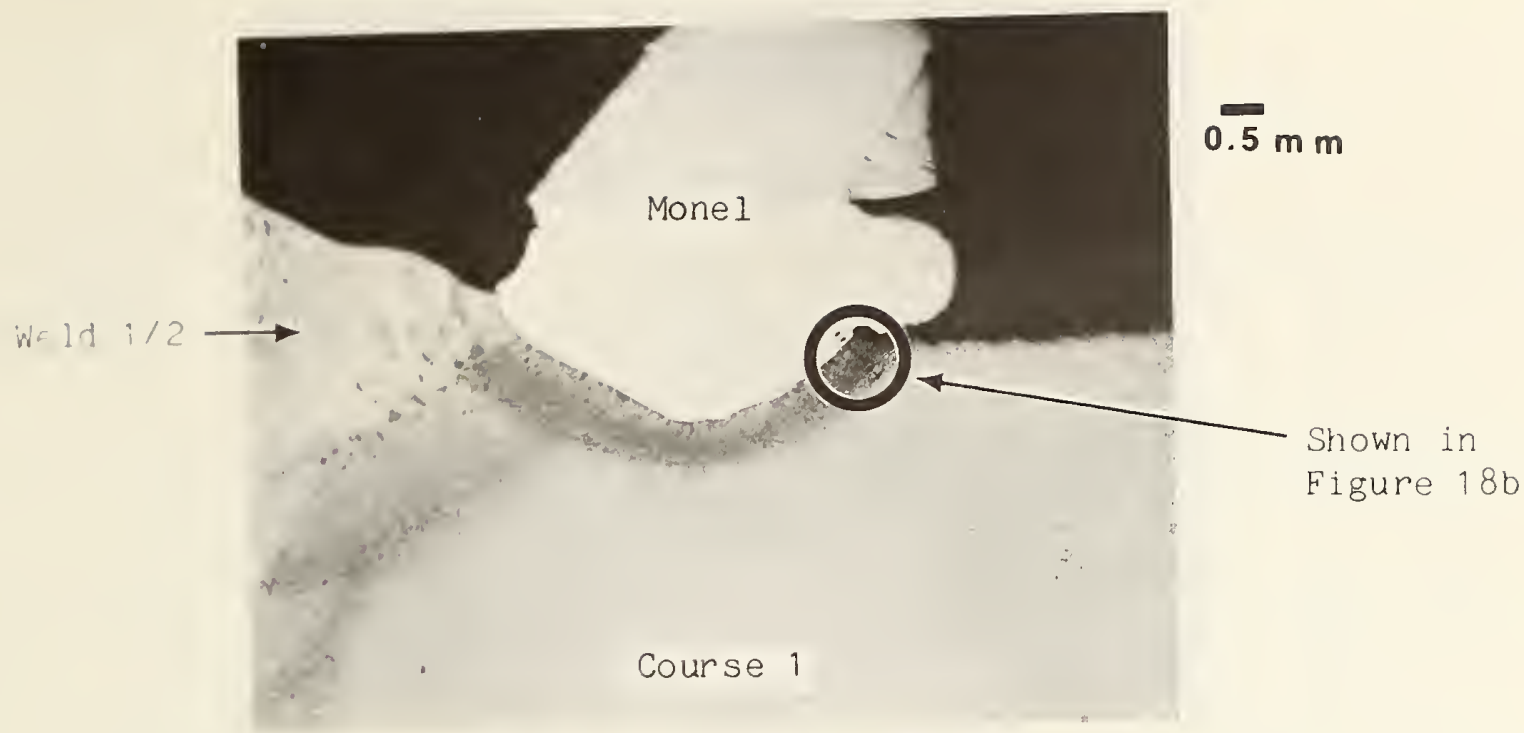

a. Microstructure of the Monel-to-steel weld

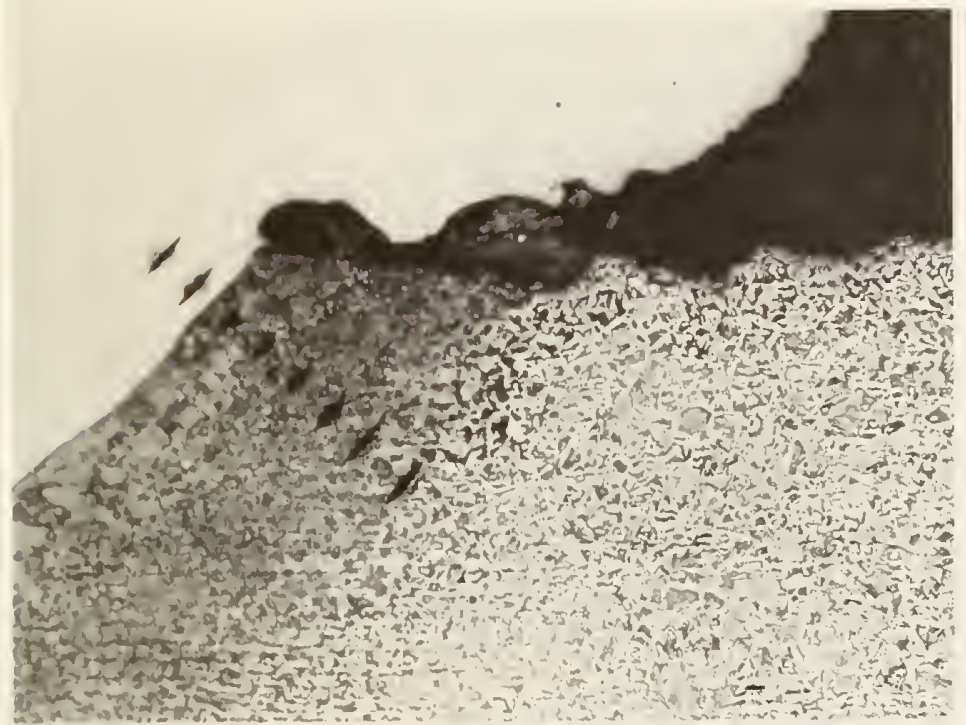

b. Knoop hardness indentations $\overline{\mathbf{2 \mu m}}$

Mone 1

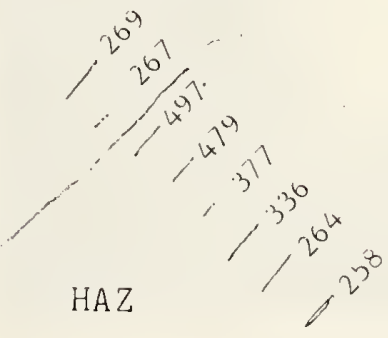

Base

Metal

c. Knoop hardness values, HK 500 (tracing of Fig. 18b)

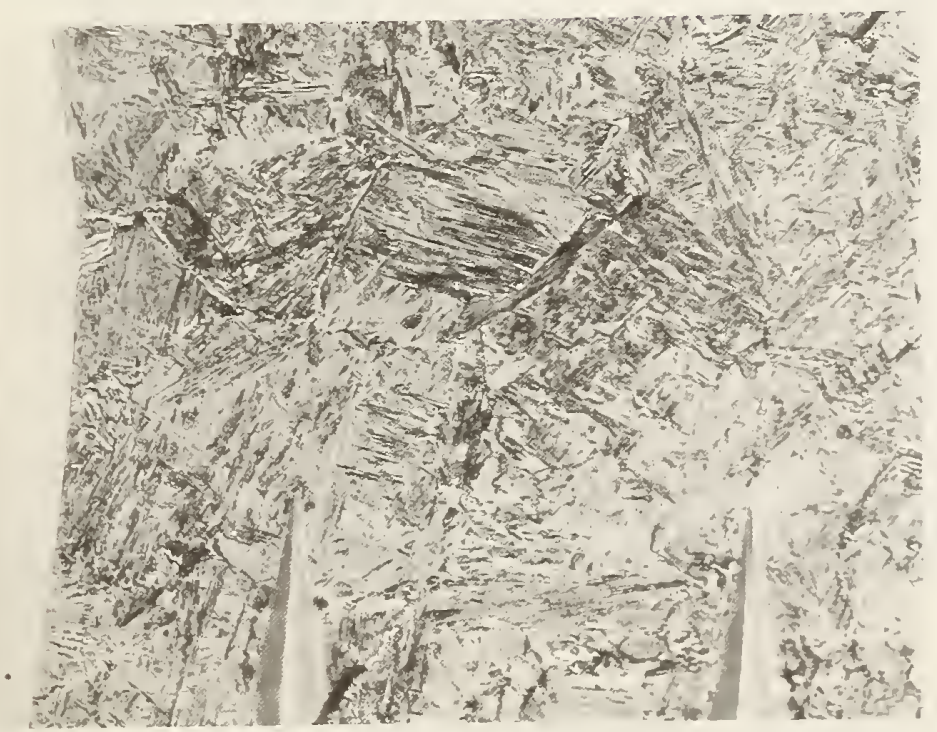

$25 \mu \mathrm{m}$

d. Microstructure at location of highest hardness in Figure 18b.

Figure 18. Microhardness of the HAZ of the Monel-to-steel weld at thr location shown in Figure 17a. Etchant: $2 \%$ nital 
Tests to evaluate the steel plates and welds used for initial construction and for replacement of Course 2 indicated that:

1. The steel plates and welds met the specified requirements for chemical composition and tensile properties.

2. The toughness of the repair welds was significantly higher than that of the steel plates.

3. The tensile strength and hardness of the welds and plates were comparable.

4. The properties of the steel used to replace Course 2 were similar to those of the original steel.

5. Field welding done to replace Course 2 resulted in hard regions in the HAZs near the plate surfaces. The hard regions contained martensite, a microstructure known to be susceptible to hydrogen stress cracking.

6. Installation of the Monel liner resulted in a hard microstructure in the vessel steel where the Monel was welded to the steel.

7. Hard microstructures were not found in the HAZs of the original construction welds or in the vertical field welds within Course 2. 

Pressure vessel 120701 had a history of damage by corrosion and hydrogen cracking. Replacement of Course 2 and installation of the Monel liner were necessitated by the detection of blisters and delaminations in Courses 1 and 2. It is likely that the extensive cracking observed by MPI was caused by corrosion or hydrogen-induced cracking. A limited testing program was undertaken to help clarify the mechanisms of the cracking observed in the vesse 1.

There are many manifestations of stress corrosion cracking and hydrogeninduced cracking, and various terms are used to describe these phenomena. For the purpose of this report, stress corrosion cracking refers to cracking due to the combined action of corrosion and tensile stress. In this case the corrosive environment was an aqueous solution of MEA (20\% by volume) containing $\mathrm{H}_{2} \mathrm{~S}$. Hydrogen-induced cracking is used as a general term to describe cracking by several mechanisms including two of interest in this investigation: hydrogen pressure cracking and hydrogen stress cracking. In the pressure vessel, the source of hydrogen was $\mathrm{H}_{2} \mathrm{~S}$, which decomposed at the steel surface. The hydrogen then permeated into the steel where it was free to diffuse as atomic hydrogen.

Hydrogen pressure cracking occurs owing to the formation of molecular hydrogen at internal defects such as inclusions. As hydrogen continues to enter the steel and diffuse to the defect, high pressures develop, interfacial separation occurs, and eventually the steel enclosing the hydrogen deforms plastically and ruptures. Blisters and delaminations are formed by this mechanism. This type of cracking is observed in steels, including lowstrength steels, exposed to corrosive environments containing $\mathrm{H}_{2} \mathrm{~S}$.

Hydrogen stress cracking occurs by a mechanism that remains unknown. However, it has been extensively studied and many of the characteristics are well-known. Hydrogen stress cracking occurs in high-hardness steels under sustained load at tensile stresses below the yield strength. Hydrogen diffuses to regions of stress concentration, and in susceptible materials, brittle cracking occurs. This type of cracking was observed in the studies discussed in the Fracture Surface Observations section. Another form of hydrogen stress cracking characteristically occurs in the welding of steels and is referred to as hydrogen-induced cold cracking. 


\section{Hydrogen Pressure Cracking}

The susceptibility of the vessel steels to hydrogen pressure cracking was evaluated using the procedures of NACE Standard TM-02-84 [8]. NACE refers to this type of cracking as stepwise cracking induced by hydrogen absorption from aqueous sulfide corrosion. Two base metal specimens each were tested from Course 1 and Course 2. Weld $2 / 3$ was tested using two specimens oriented transversely to the weld, and thus contained steel from Courses 2 and 3 . The orientation of the specimen with respect to the curvature and grain orientation of the plate is shown in Figure 20. This is the same orientation with respect to curvature as that specified in the NACE standard. However, the sections examined metallographically were parallel to the direction of rolling, whereas the NACE standard specifies sections transverse to the rolling direction. The NACE specification was developed for line pipe where the rolling direction is parallel to the pipe axis, whereas in pressure vessels, the rolling direction is perpendicular to the cylindrical ax is.

The tests were conducted by placing the specimens in substitute seawater prepared according to ASTM D 1141 [9] and then saturating the sea water with $\mathrm{H}_{2} \mathrm{~S}$. After saturation, $\mathrm{H}_{2} \mathrm{~S}$ was bubbled through the solution continuously for the duration of the tests. All specimens were immersed simultaneously for a duration of $96 \mathrm{~h}$. The specimens were then removed from the solution, cleaned, and examined.

All specimens developed blisters of the type shown in Figure 21. In the welded specimens, blisters formed on the base metal, but not on the weld. Note that the specimens shown in Figures $21 \mathrm{e}$ and $21 \mathrm{f}$ were not metallographically prepared and etched, and the welds cannot be seen. The specimens were sectioned and examined for hydrogen pressure cracking at the locations shown in Figure 20, and the susceptibility to cracking was characterized in terms of the ratios defined by NACE:

Crack Sensitivity Ratio, $\operatorname{CSR}=\frac{\sum(\mathrm{a} \times \mathrm{b})}{\mathrm{W} \times \mathrm{T}} \times 100 \%$,

Crack Length Ratio, $\operatorname{CLR}=\frac{\sum \mathrm{a}}{\mathrm{W}} \times 100 \%$,

Crack Thickness Ratio, $\mathrm{CTR}=\frac{\sum \mathrm{b}}{\mathrm{T}} \times 100 \%$, 


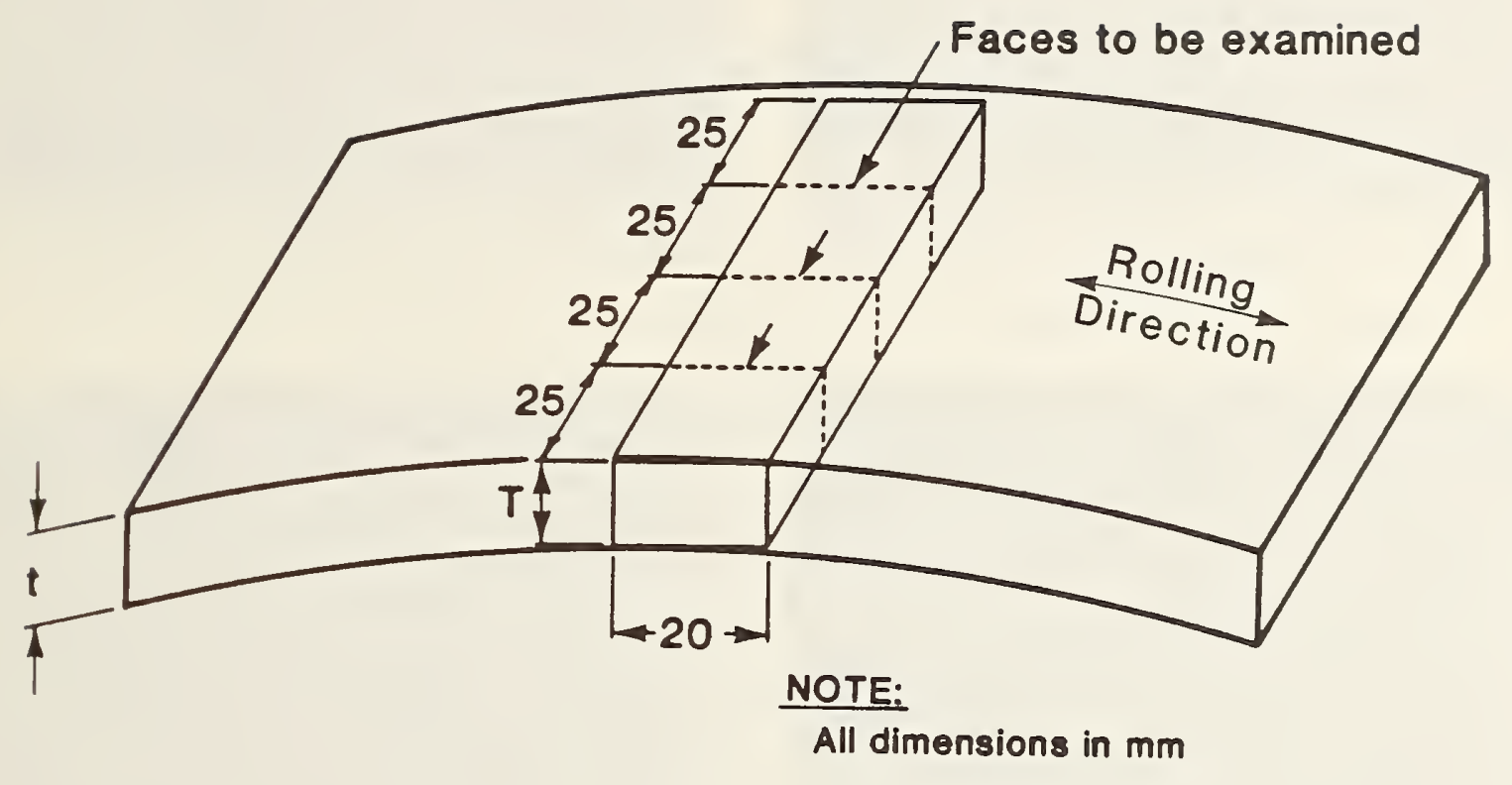

Figure 20. Specimen for measuring susceptibility to hydrogen pressure cracking. 
where $\mathrm{a}=$ crack length,

$b=$ crack thickness,

$W=$ section width,

and $T=$ specimen thickness.

The results, summarized in Table $\mathrm{V}$, indicate that the $A 516$ Grade 70 steel from both Courses 1 and 2 is susceptible to hydrogen pressure cracking in the NACE solution [8].

The results also show that Course 1 steel is more susceptible to hydrogen pressure cracking than the Course 2 steel. This is consistent with the lower levels of inclusion formers, sulfur and aluminum, in the course 2 stee 1. No cracking was observed in the welds, but cracks did form in the HAZ. Metallographic sections of typical cracks are shown in Figure 22. The linkage of several hydrogen pressure cracks into a surface-breaking crack is shown in Figure 22a. The size and orientation of the hydrogen pressure cracks is not simply related to the microstructure, as shown in Figure $22 b$. The cracks that developed in HAZ 3 of Weld $2 / 3$ are shown in Figure $22 \mathrm{c}$.

\section{Hydrogen-Induced Cold Cracking}

Magnetic particle inspection revealed numerous cracks in the HAZ of Welds $1 / 2$ and $2 / 3$. These cracks may have formed at the time course 2 was replaced or during operation of the vessel. A possible cause of cracking at the time of repair welding is hydrogen-induced cold cracking. This type of cracking tends to occur in the $\mathrm{HAZ}$ of steel welds when the hardness is high and hydrogen is present.

A series of $y$-groove cracking tests were conducted to evaluate the susceptibility of the steel plates from Courses 1 and 2 to cold cracking due to welding. The tests were carried out in accordance with Japanese Industrial Standard JIS Z 3158 [8] using the specimen shown in Figure 23. The procedures and results are discussed in Appendix E. In the first $y$-groove tests, one specimen of Course 1 material and one specimen of Course 2 material were welded by the shielded metal arc method at room temperature using dried electrodes of type AWS E 7018. No cracking was observed in either specimen. 
Table V. Results of hydrogen-pressure cracking tests.

\begin{tabular}{|c|c|c|c|c|}
\hline $\begin{array}{l}\text { Specimen } \\
\text { Location }\end{array}$ & Section & $\begin{array}{l}\text { Crack Sensitivity } \\
\text { Ratio, \% }\end{array}$ & $\begin{array}{l}\text { Crack Leng th } \\
\text { Ratio, \% }\end{array}$ & $\begin{array}{l}\text { Crack } \\
\text { Ratio }\end{array}$ \\
\hline \multicolumn{5}{|l|}{ Course 1} \\
\hline \multirow[t]{2}{*}{ B4 } & $\begin{array}{l}1 \\
2 \\
3\end{array}$ & $\begin{array}{l}1.7 \\
0.3 \\
0.9\end{array}$ & $\begin{array}{l}80.3 \\
24.2 \\
27.6\end{array}$ & $\begin{array}{l}3.8 \\
2.7 \\
3.4\end{array}$ \\
\hline & Avg. & 1.0 & 44.1 & 3.3 \\
\hline \multirow[t]{2}{*}{$\mathrm{C} 4$} & $\begin{array}{l}1 \\
2 \\
3\end{array}$ & $\begin{array}{l}0.1 \\
5.2 \\
2.1\end{array}$ & $\begin{array}{l}23.8 \\
67.2 \\
59.5\end{array}$ & $\begin{array}{l}1.3 \\
7.8 \\
3.5\end{array}$ \\
\hline & Avg. & 2.5 & 50.2 & 4.2 \\
\hline
\end{tabular}

\section{Course 2}

\begin{tabular}{|c|c|c|c|c|}
\hline \multirow[t]{2}{*}{ X } & $\begin{array}{l}1 \\
2 \\
3\end{array}$ & $\begin{array}{l}0.6 \\
0.1 \\
0.2\end{array}$ & $\begin{array}{l}45.1 \\
14.5 \\
24.2\end{array}$ & $\begin{array}{l}2.8 \\
1.4 \\
2.6\end{array}$ \\
\hline & Avg. & 0.3 & 27.9 & 2.3 \\
\hline$y$ & $\begin{array}{l}1 \\
2 \\
3\end{array}$ & $\begin{array}{l}0.1 \\
0.0 \\
0.2\end{array}$ & $\begin{array}{r}8.5 \\
8.1 \\
25.5\end{array}$ & $\begin{array}{l}1.1 \\
0.3 \\
2.1\end{array}$ \\
\hline & Avg. & 0.1 & 14.0 & 1.2 \\
\hline
\end{tabular}

Weld $2 / 3$

\begin{tabular}{|c|c|c|c|c|}
\hline \multirow[t]{2}{*}{ I2 } & $\begin{array}{l}1 \text { (Course } 2 \text { side) } \\
2 \text { We ld } 2 / 3 \\
3 \text { (Course } 3 \text { side) }\end{array}$ & $\begin{array}{l}0.0 \\
0.1 \\
0.2\end{array}$ & $\begin{array}{r}0.0 \\
6.6 \\
10.4\end{array}$ & $\begin{array}{l}0.0 \\
2.9^{*} \\
3.1\end{array}$ \\
\hline & Avg. & 0.1 & 5.6 & 2.0 \\
\hline J2 & $\begin{array}{l}1 \text { (Course } 3 \text { side) } \\
2 \text { We Id } 2 / 3 \\
3 \text { (Course } 2 \text { side) }\end{array}$ & $\begin{array}{l}0.1 \\
0.0 \\
0.0\end{array}$ & $\begin{array}{l}6.9 \\
0.0 \\
0.0\end{array}$ & $\begin{array}{l}3.0 \\
0.0 \\
0.0\end{array}$ \\
\hline & Avg. & 0.0 & 2.3 & 1.0 \\
\hline
\end{tabular}

* Crack in HAZ of Course 2 side 


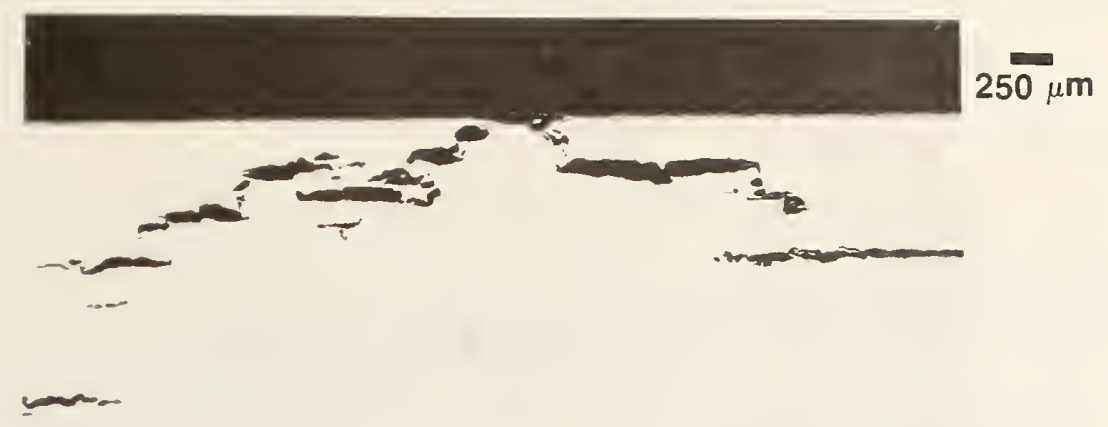

a. Specimen 64 from Course 1 (as polished)

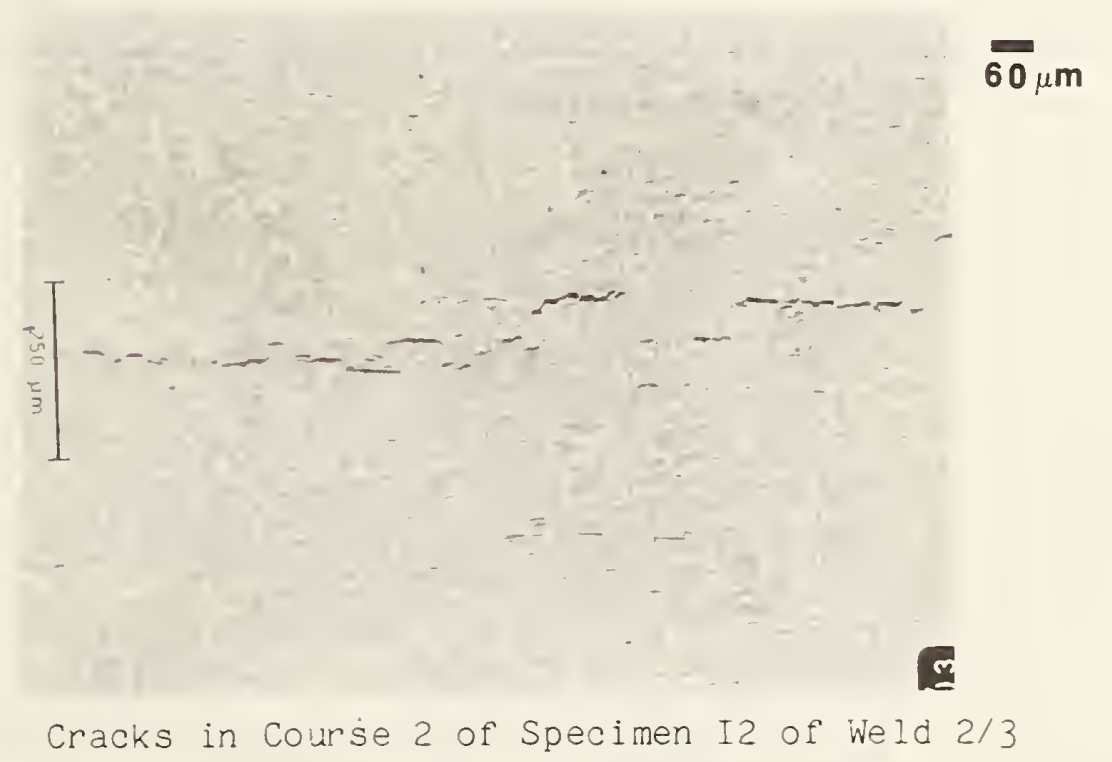

b. Cracks in Course 2 of Specimen I2 of Weld 2/3

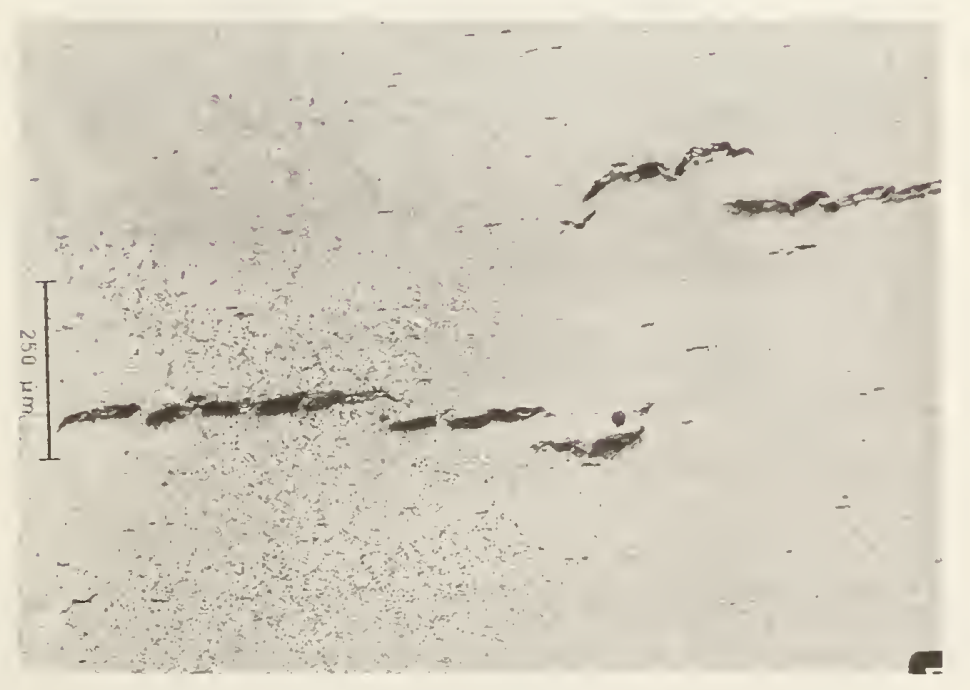

c. Cracks in HAZ 3 of Specimen I2 of Weld $2 / 3$

Figure 22. Metallography of cracking in specimens after hydrogen prwasure cracking tests. 

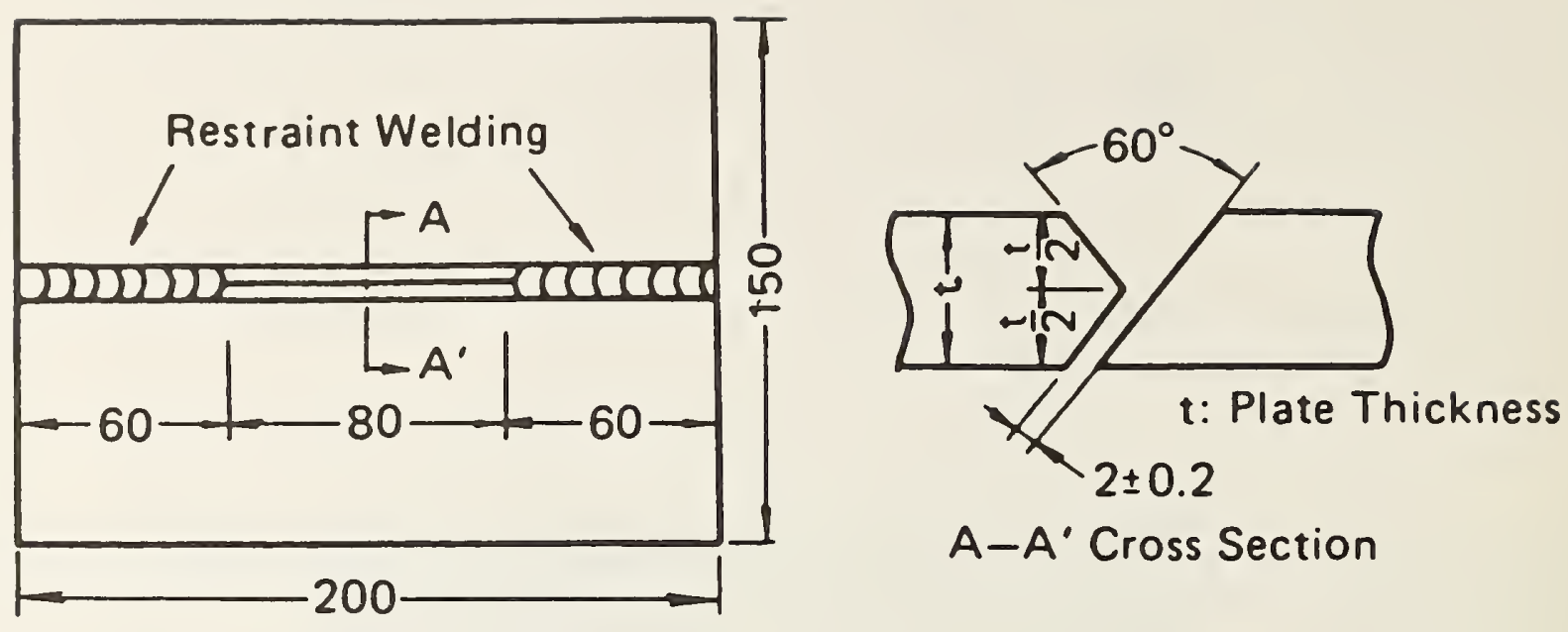

$A-A^{\circ}$ Cross Section

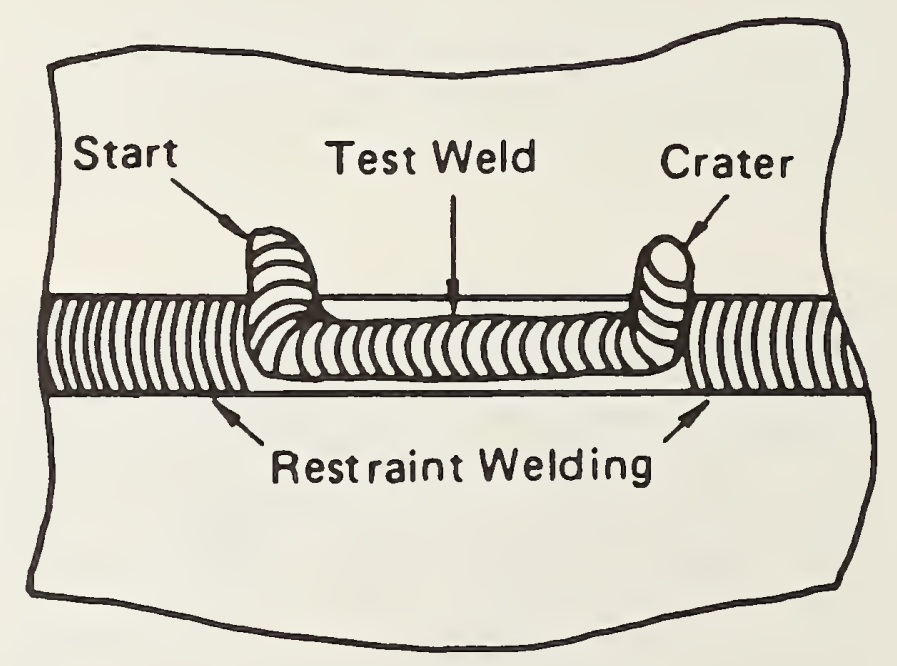

Figure 23. Specimen for $y$-groove weldability test. 
Next, a specimen was prepared that simulated two conditions that may have existed at the time of the repair: 1) the Course 1 steel may have been hydrogen charged at the time of repair welding because of the prior service, and 2) welding may have been done on a cool day $\left(-1^{\circ} \mathrm{C}, 34^{\circ} \mathrm{F}\right)$ without preheat. The test was conducted on a duplex specimen consisting of course 1 steel on one side and Course 2 steel on the other. The Course 1 side of the specimen was charged with hydrogen by soaking it in the NACE solution (NACE Standard TM-01-77) [10] for $80 \mathrm{~h}$. The NACE solution is an acidic ( $\mathrm{pH}=3$ ) saltwater saturated with $\mathrm{H}_{2} \mathrm{~S}$. The duplex specimen was cooled to $1^{\circ} \mathrm{C}\left(34^{\circ} \mathrm{F}\right)$ and welded using the standard procedures [8]. It cracked at the root of the weld on Course 1 (hydrogen-charged) side. A cross section of the specimen is presented in Figure $24 \mathrm{a}$. The root cracking, shown in Figure $24 \mathrm{~b}$, occurred in the coarse-grain part of the HAZ. The microhardness in the vicinity of the crack was typically 350 on the Vickers scale indicating the presence of martensite.

The results indicate that Course 1 was susceptible to cold cracking if charged with hydrogen and welded without preheat. Thus, cold cracking could have occurred at the time Course 2 was replaced. However, the numerous cracks observed by MPI in Course 2 cannot be attributed to cold cracking on the basis of these tests. Also, if cold cracking was prevalent in Course 1 , it may have occurred on either the inside or the outside surface of the vessel. The HAZ of Weld 1 on the outside surface of Ring 1 was checked for cracking by MPI in the limited regions where the fracture did not occur along HAZ 1 ; no cracks were found.

\section{Stress Corrosion Cracking}

The susceptibility of the vessel steels to stress corrosion cracking in the $\mathrm{MEA} / \mathrm{H}_{2} \mathrm{~S}$ environment was evaluated by slow strain rate tensile testing. Tests were conducted at room temperature on $4 \mathrm{~mm}(0.16 \mathrm{in}$ ) ) diameter, $25 \mathrm{~mm}$ ( 1 in.) gage length specimens in a screw-driven tensile machine at a constant displacement rate of $10^{-6} \mathrm{~cm} / \mathrm{s}\left(0.4 \times 10^{-6} \mathrm{in./ \textrm {s }}\right)$. Base metal specimens were taken from courses 1 and 2 and a transverse weld specimen was taken across Weld 2/3. One control specimen of each material type was tested in air and 


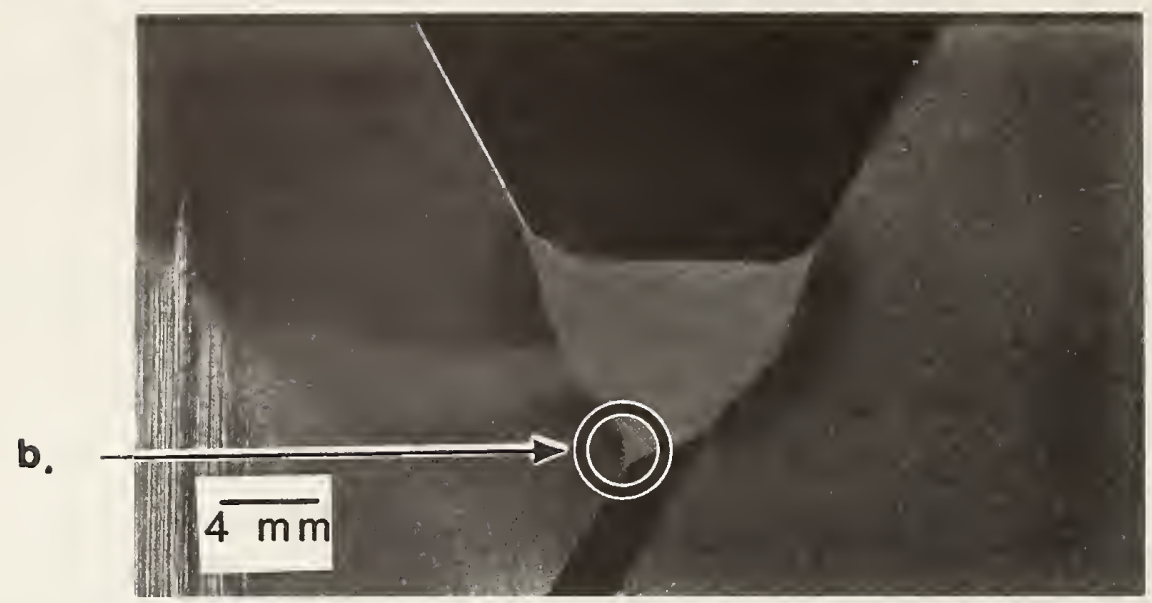

a. Macrostructure of $y$-groove test

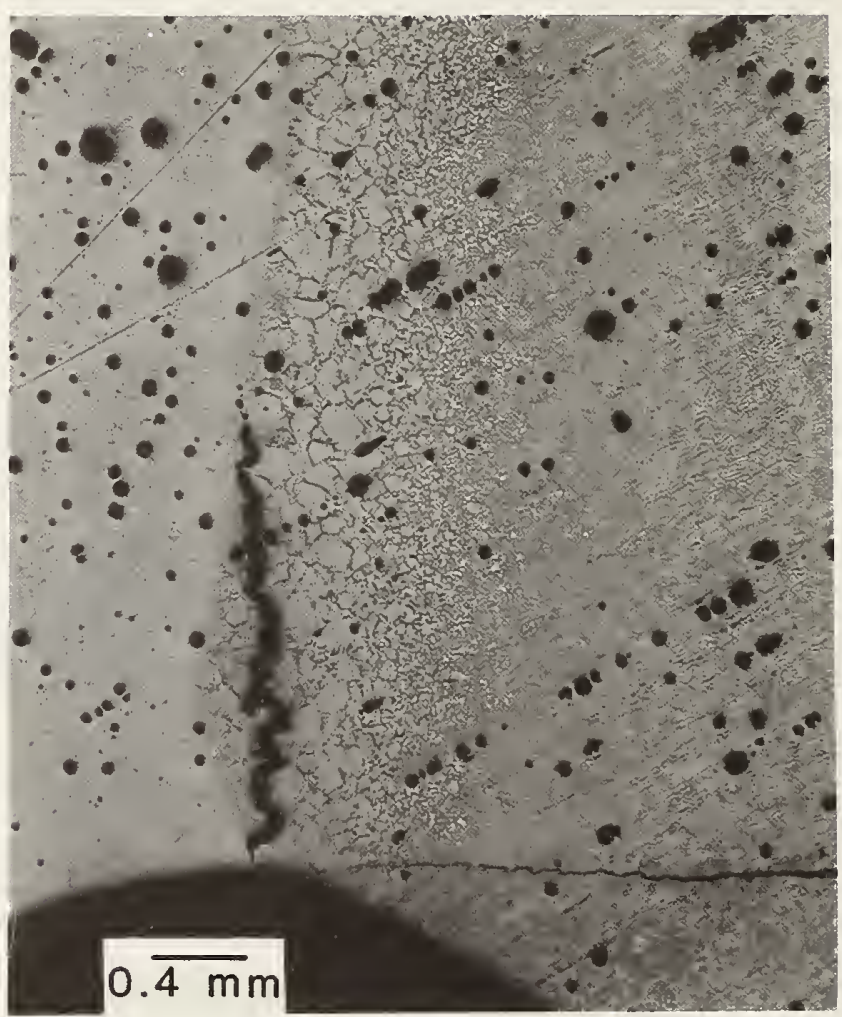

b. Root cracking in y-groove test in HAZ 1

Figure 24. Cross section of $y$-groove test specimen of Course 1 stee I welded to Course 2 steel showing cracking in HAZ 1. 
one specimen was tested in a 20\% aqueous solution of MEA containing approximately 0.83 molar $\mathrm{H}_{2} \mathrm{~S}$. The results are summarized in Table VI. The strength and ductility values are essentially the same in air and in the $M E A / H_{2} S$ environment. Thus, the materials did not exhibit any susceptibility to stress corrosion cracking under the conditions evaluated.

\section{Galvanic Corrosion}

The galvanic couple between the Monel liner and the steel vessel was studied by measuring the current flow between steel (from Course 1) and Monel (from the liner) in the $\mathrm{MEA} / \mathrm{H}_{2} \mathrm{~S}$ solution. The experiments indicated that the current density was typically quite low, on the order of $1 \mu \mathrm{A} / \mathrm{cm}^{2}$ $\left(6.5 \mu \mathrm{A} / \mathrm{in} .^{2}\right)$. The tests were conducted using the apparatus shown in Figure 25 .

The steel surfaces not facing the Monel were masked with lacquer. The areas of the electrodes were $12.2 \mathrm{~cm}^{2}\left(1.9 \mathrm{in}^{2}\right)$ for the steel and $62.2 \mathrm{~cm}^{2}$ ( $9.6 \mathrm{in.}^{2}$ ) for the Monel. In the first test, steel electrodes were placed on either side of the Monel electrode, one at a spacing, d, of $1 \mathrm{~mm}(0.04 \mathrm{in}$.) and the other at a spacing of $10 \mathrm{~mm}(0.4 \mathrm{in.})$. Current measurements were initially made at room temperature; then the bath temperature was raised to $52^{\circ} \mathrm{C}$ $\left(126^{\circ} \mathrm{F}\right)$ and a second set of data was recorded. The bath was held at $41^{\circ} \mathrm{C}$ $\left(106^{\circ} \mathrm{F}\right.$ ) overnight and a final reading was taken after $24 \mathrm{~h}$. The experimental results, presented in Table VII, indicate a particularly high current flow after $84 \mathrm{~min}$. The results also indicated a change of polarity. The steel was initially anodic with respect to the Monel, but changed to cathodic within $20 \mathrm{~min}$. for an electrode separation of $1 \mathrm{~mm}(0.04 \mathrm{in}$.) and within $84 \mathrm{~min}$. for an electrode separation of $10 \mathrm{~mm}(0.04 \mathrm{in.})$.

Two additional experiments were conducted under simplified conditions to confirm the observations made in the first experiment. The simplifications were 1 ) to use a single electrode couple and 2) to conduct the test at constant temperature. Experiment 2 was conducted at room temperature with an electrode separation of $10 \mathrm{~mm}(0.4 \mathrm{in}$.). Experiment 3 was conducted at $42^{\circ} \mathrm{C}\left(108^{\circ} \mathrm{F}\right)$ with an electrode separation of $8 \mathrm{~mm}(0.3 \mathrm{in.})$. The results of these tests are summarized in Table VII. Both tests revealed a reversal of polarity, i.e., the steel was initially anodic but became cathodic with 


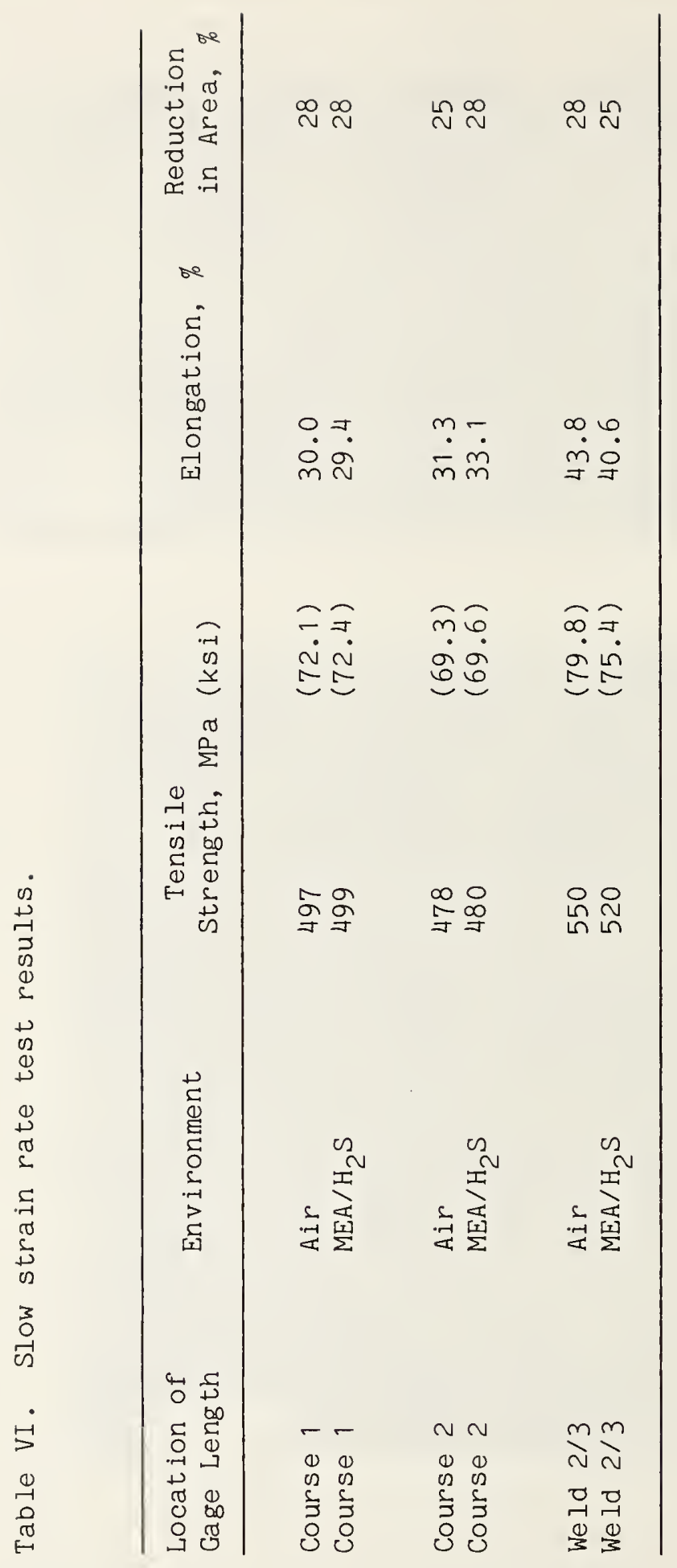




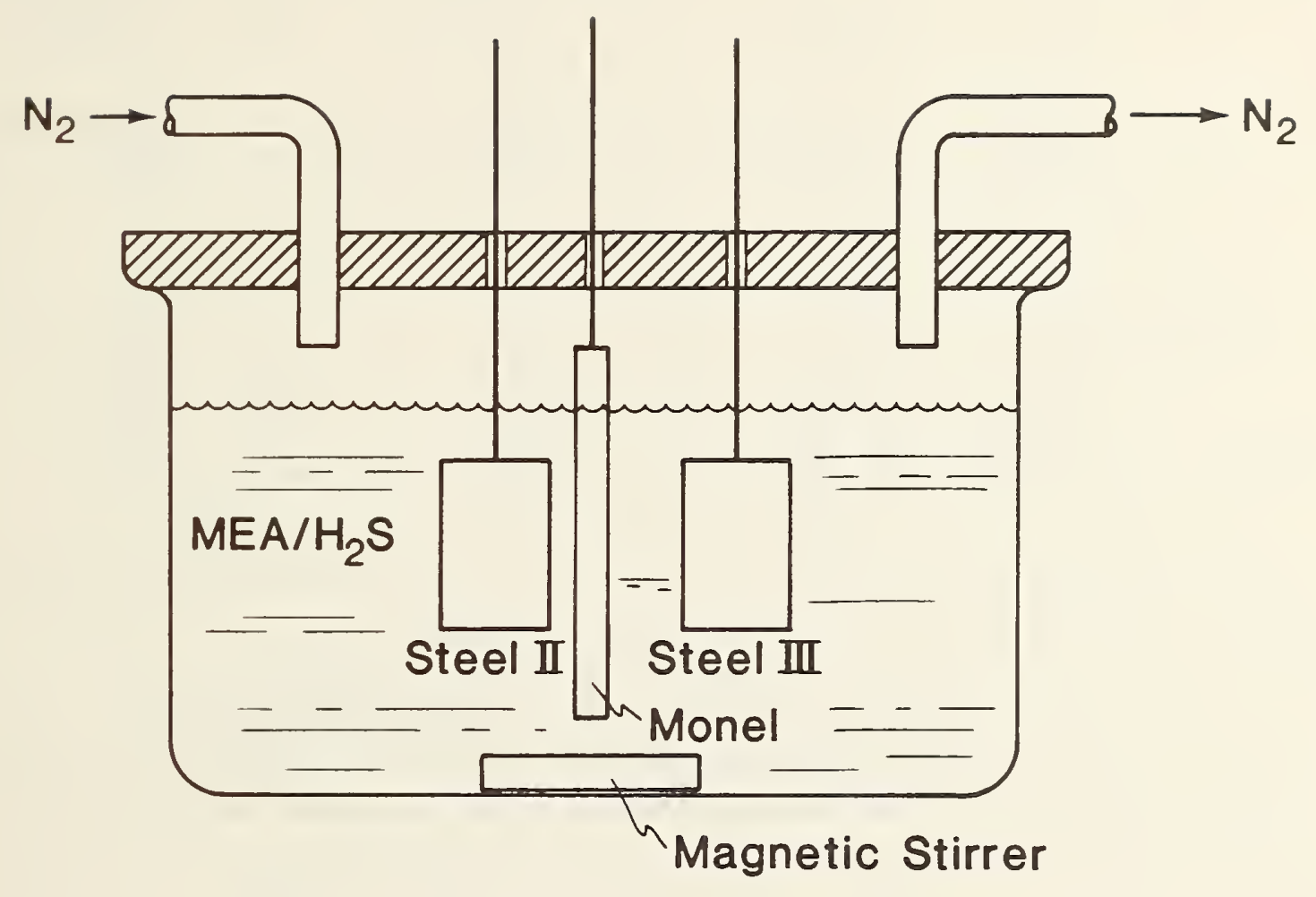

Figure 25. Test apparatus for galvanic corrosion studies. 
Table VII. Results of the galvanic corrosion tests.

Summary of Experiment 1

\begin{tabular}{|c|c|c|c|c|c|c|}
\hline \multirow[b]{2}{*}{ Time } & \multirow{2}{*}{\multicolumn{2}{|c|}{$\begin{array}{l}\text { Temperature } \\
\left({ }^{\circ} \mathrm{C}\right) \quad\left({ }^{\circ} \mathrm{F}\right)\end{array}$}} & \multicolumn{2}{|c|}{$d=1 \mathrm{~mm}(0.04 \mathrm{in})}$. & \multicolumn{2}{|c|}{$d=10 \mathrm{~mm}(0.4 \mathrm{in.})$} \\
\hline & & & $\begin{array}{c}\text { Current } \\
\mu \mathrm{A}\end{array}$ & $\begin{array}{l}\text { Status of } \\
\text { Steel vs. Monel }\end{array}$ & $\begin{array}{c}\text { Current } \\
\mu \mathrm{A}\end{array}$ & $\begin{array}{l}\text { Status of } \\
\text { Steel vs. Monel }\end{array}$ \\
\hline 0 & 21 & (70) & 15 & Anodic & 100 & Anodic \\
\hline $14 \mathrm{~min}$. & 21 & (70) & 0 & ---- & 10 & Anodic \\
\hline $20 \mathrm{~min}$. & 21 & (70) & 20 & Cathodic & 6 & Anodic \\
\hline $48 \mathrm{~min}$. & 21 & (70) & 20 & Cathodic & 3 & Anodic \\
\hline
\end{tabular}

$\begin{array}{lrrrrrr}56 \text { min. } & 26 & (79) & 20 & \text { Cathodic } & 5 & \text { Anodic } \\ 72 \mathrm{~min} . & 44 & (111) & 45 & \text { Cathodic } & 8 & \text { Anodic } \\ 77 \mathrm{~min} . & 49 & (120) & 70 & \text { Cathodic } & 0 & --- \\ 84 \mathrm{~min} . & 52 & (126) & 5000 & \text { Cathodic } & 1600 & \text { Cathodic } \\ 96 \mathrm{~min} . & 52 & (126) & 110 & \text { Cathodic } & 30 & \text { Cathodic } \\ 2 \mathrm{~h} 15 \mathrm{~min} . & 47 & (117) & 25 & \text { Cathodic } & 19 & \text { Cathodic } \\ \text { Overnight } & 41 & (106) & & & \\ 24 \mathrm{~h} & 41 & (106) & 2 & \text { Cathodic } & & \end{array}$

Summary of Experiment 2

\begin{tabular}{|c|c|c|c|c|}
\hline \multirow[b]{2}{*}{ Time } & & \multicolumn{2}{|c|}{$d=10 \mathrm{~mm}(0.4 \mathrm{in.})$} \\
\hline & \multicolumn{2}{|c|}{$\begin{array}{l}\text { Temperature } \\
{ }^{\circ} \mathrm{C} \quad\left({ }^{\circ} \mathrm{F}\right)\end{array}$} & $\begin{array}{c}\text { Current } \\
\mu \mathrm{A}\end{array}$ & $\begin{array}{l}\text { Status of } \\
\text { Steel vs. Monel }\end{array}$ \\
\hline 0 & 22 & $(72)$ & 100 & Anodic \\
\hline $15 \mathrm{~min}$. & 22 & $(72)$ & 10 & Anod ic \\
\hline $60 \mathrm{~min}$. & 22 & $(72)$ & 5 & Anodic \\
\hline $2 \mathrm{~h} 10 \mathrm{~min}$. & 22 & $(72)$ & 0 & ---- \\
\hline $2 \mathrm{~h} 20 \mathrm{~min}$. & 22 & $(72)$ & 0.4 & Cathodic \\
\hline 2 n 35 min. & 22 & $(72)$ & 0 & $\ldots \ldots$ \\
\hline $4 \mathrm{~h}$ & 22 & (72) & 11 & Anodid \\
\hline $6 \mathrm{~h} 20 \mathrm{~min}$ & 22 & $(72)$ & 0 & --- \\
\hline $8 \mathrm{~h}$ & 22 & (72) & 1 & Cathod ic \\
\hline $12 \mathrm{n}$ & 22 & $(72)$ & 12 & Cathodic \\
\hline $24 \mathrm{n}$ & 22 & (72) & 12 & Cathod ic \\
\hline $48 h$ & 22 & $(72)$ & 20 & Cathodic \\
\hline
\end{tabular}

Surmary of Experiment 3

\begin{tabular}{|c|c|c|c|c|}
\hline \multirow{3}{*}{ Time } & & & \multicolumn{2}{|c|}{$d=8 \mathrm{~mm}(0.3 \mathrm{in.})$} \\
\hline & \multicolumn{2}{|c|}{ Temperature } & \multirow{2}{*}{$\begin{array}{c}\text { Current } \\
\mu \mathrm{A}\end{array}$} & \multirow{2}{*}{$\begin{array}{c}\text { Status of } \\
\text { Steel vs. Monel }\end{array}$} \\
\hline & ${ }^{\circ} \mathrm{C}$ & $\left({ }^{\circ} \mathrm{F}\right)$ & & \\
\hline 0 & 35 & (95) & 1000 & Anodic \\
\hline 20 min. & 40 & $(104)$ & 40 & Anodic \\
\hline $35 \mathrm{~min}$. & -- & & 10 & Anodic \\
\hline 55 min. & 43 & $(109)$ & 0 & --- \\
\hline $2 n$ & 42 & $(108)$ & 10 & Cathodic \\
\hline $4 \mathrm{~h}$ & 42 & $(108)$ & 8 & Cathodic \\
\hline $16 \mathrm{~h}$ & -- & & 5 & Cathodic \\
\hline $24 h$ & 42 & $(108)$ & 5 & Cathodic \\
\hline
\end{tabular}


respect to the Monel. After the initial current decayed, the current density dropped to approximately $1 \mu \mathrm{A} / \mathrm{cm}^{2}$ within $35 \mathrm{~min}$. in both tests. The polarization reversal and the low current densities were attributed to the passivating effect of a black deposit that was presumed to be a compound of iron and sulfur.

\section{Fracture Mechanics Test for Stress Corrosion Cracking}

The susceptibility of the vessel steel to stress corrosion cracking along the HAZ was evaluated ${ }^{*}$ using the bolt-loaded specimen shown in

Figure 26. The test environment was the $M E A / H_{2} S$ solution at room temperature. Exposure time was $1008 \mathrm{~h}$. Four specimens from Weld 2/3 were tested, two with the crack in HAZ 2 and two with the crack in HAZ 3.

The tests were conducted in accordance with the procedures used by Novak and Rolfe [11]. The specimens were loaded to a stress intensity level of approximately $22 \mathrm{MPa} \sqrt{\mathrm{m}}(20 \mathrm{ksi} \sqrt{\mathrm{in}}$ ) , the maximum stress intensity that met the ASTM E 399 criteria for plane strain [12]. Load was applied by torquing the bolt to a predetermined displacement level of $0.14 \mathrm{~mm}$ (0.0055 in.). After loading, the specimens were immersed in the $M E A / H_{2} S$ solution for the duration of the test. The specimens were checked during the course of the test, but no crack extension was observed. Careful examination after $1008 \mathrm{~h}$ again revealed no crack extension at the surface.

Two of the specimens were unloaded after immersion for $1008 \mathrm{~h}$, one from HAZ 2 and the other from HAZ 3. The specimens were unloaded by turning the

* The results of the stress corrosion cracking tests presented in this section are not considered reliable by NBS because the fatigue precracking loads were approximately 40\% higher than the sustained loads used during the stress corrosion test. The influence of higher fatigue loads is not known, but good practice would have been to use lower fatigue loads than the sustained loads. The procedures and results are presented here in as a record of the work done. The mistake was not discovered until completion of the tests, and the influence of the mistake on the results is not known. 


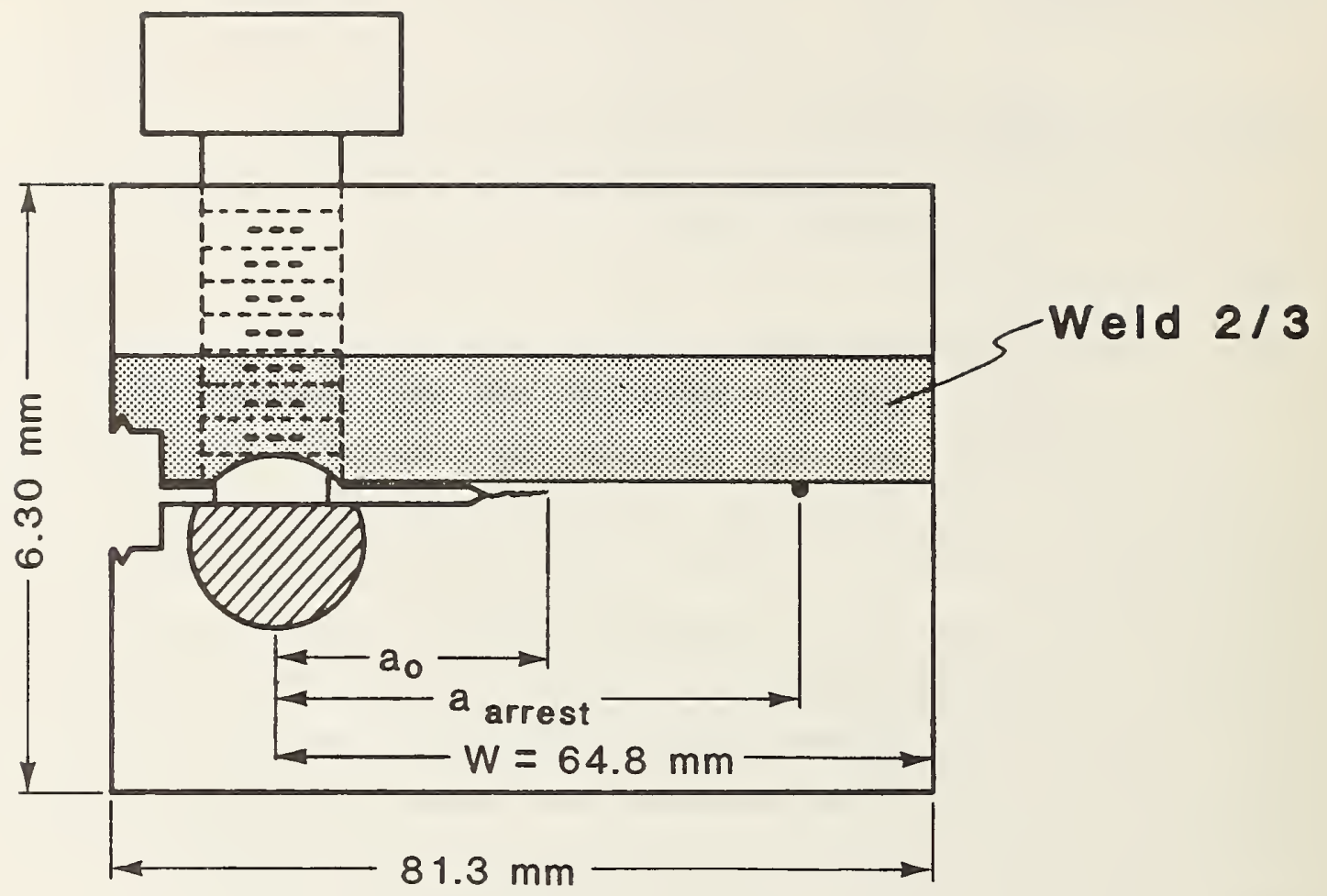

Figure 26. Specimen for fracture mechanics test of stress corrosion cracking susceptibility. 
bolt until it was loose. The displacement change as the crack was unloaded was measured with a clip gage. After unloading, the specimen was loaded in a screw-driven tensile machine to its initial displacement, measured by the same clip gage. The load to achieve the displacement was measured and recorded. The specimen was then unloaded and cooled in liquid nitrogen to $77 \mathrm{~K}\left(-321^{\circ} \mathrm{F}\right)$. The cooled specimen was loaded to failure immediately after taking it from the liquid nitrogen. The crack length at fracture (and at the end of the stress corrosion test) was measured on the exposed fracture surfaces.

The fracture surfaces of the broken specimens were examined using a X30 optical microscope to see if any sustained-load cracking had occurred during the test. No evidence of cracking beyond the initial fatigue crack front was observed in either specimen. Using the initial crack size and the load required to open the specimen to its final displacement level, the stress intensity, $\mathrm{K}$, was calculated to be $20.9 \mathrm{MPa} \sqrt{\mathrm{m}}(19.0 \mathrm{ksi} \sqrt{\mathrm{in}}$.) and $20.8 \mathrm{MPa} \sqrt{\mathrm{m}}$ (18.9 ksivin.) for the specimens of HAZ 2 and HAZ 3 , respectively. The fracture surfaces of the two specimens are shown in Figure 27. The other two specimens were returned to the solution for the indefinite future to evaluate the effect of longer exposure times. The test results are summarized in Table VIII.

\section{Chemical Analysis of Corrosion Products}

The test plate removed from Ring 1 was taken from a location covered by the Monel liner. When the liner was removed, a heavy black deposit was observed on the steel plate. The deposit had two distinct textures. In one region, it was sticky and came off in large flakes; this is referred to as Scale 1. In another region, it was dry and more powdery; this is referred to as Scale 2. Samples of Scale 1 and Scale 2 were removed and were analyzed by emission spectroscopy for elements such as iron, chromium, nickel, and manganese, and by the gas fusion method for carbon and sulfur.

The emission spectroscopy procedure was based on ASTM Committee E 02 Suggested Method, SM11-22 "Semiquantitative Spectrographic Analysis of Miscellaneous Materials by the Graphite Dilution Technique" [13]. The samples were dried at $54^{\circ} \mathrm{C}\left(130^{\circ} \mathrm{F}\right)$ for $4 \mathrm{~h}$, ground in a mullite mortar and 
$\mathrm{C} 2 \mathrm{Q}$

C $3 Q$

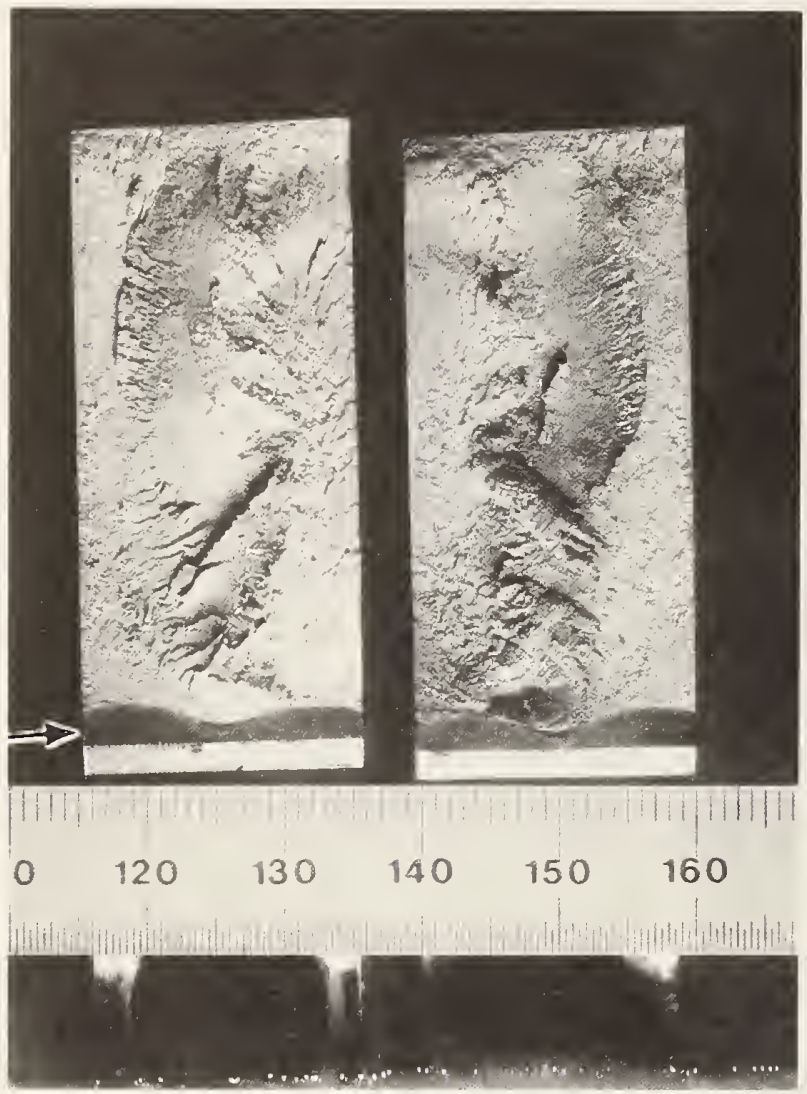

$\mathrm{C} 2 \mathrm{~T}$

C 3T

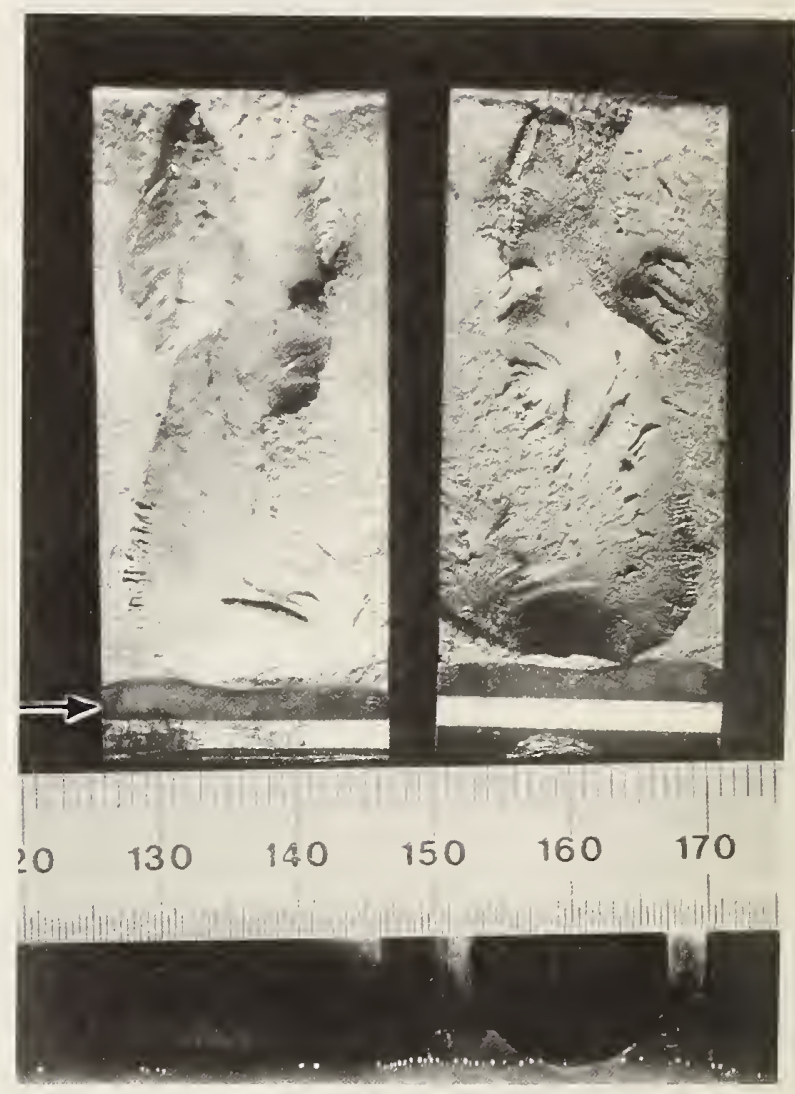

Figure 27. Fracture surfaces of specimens after completion of fracture mechanics tests of stress corrosion cracking susceptibility. Arrows point to fatigue precracks. 


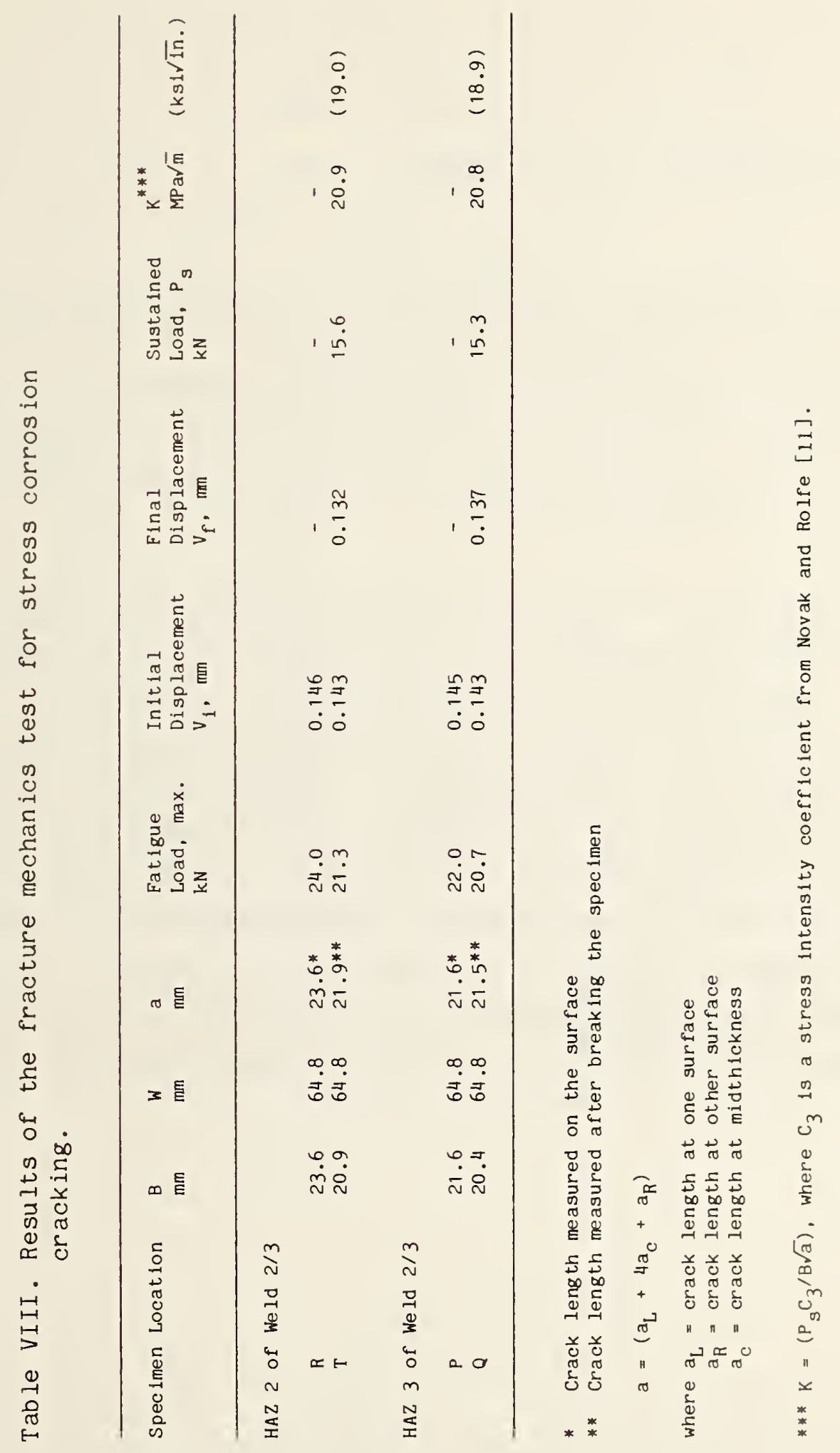


dried further overnight at $54^{\circ} \mathrm{C}$. Duplicate $1 \mathrm{mg}$ specimens were taken from both scale samples, mixed with graphite, and volatilized in a dc arc. The spectra were photographed and visually compared with commercial reference materials treated in the same manner.

The gas fusion analyses for sulfur and carbon were performed in a commercial instrument calibrated with NBS Standard Reference Materials (SRMs). For sulfur, SRM $129 \mathrm{c}$ was used for calibration and SRMs $133 \mathrm{~b}$ and 368 were run as controls. For carbon, SRM $12 \mathrm{~h}$ was used for calibration and SRMs $11 \mathrm{~h}, 129 \mathrm{c}$ and $133 \mathrm{~b}$ were run as controls. Four-gram samples were taken of each scale and dried at $115^{\circ} \mathrm{C}\left(239^{\circ} \mathrm{F}\right)$ for $48 \mathrm{~h}$. Test portions of these samples weighing 10 to $25 \mathrm{mg}$ were put into ceramic crucibles, covered with $1 \mathrm{~g}$ of $\mathrm{high}$ purity iron and $1 \mathrm{~g}$ of tungsten accelerator. Twelve test portions of scale were analyzed.

The results of the chemical analyses, summarized in Table IX, indicate that the main constituents of the black deposits are iron, sulfur, and carbon. The high sulfur content, approximately 15\% by weight, is significant because the probable source of the sulfur was sulfide corrosion of the steel vessel by the aqueous $\mathrm{H}_{2} \mathrm{~S}$ environment. This same corrosion process generates hydrogen at the steel surface, and thus, it is a probable source of the hydrogen that damaged the steel. The probable sources of the other elements detected in the black deposits were iron, manganese, and silicon from the steel; copper and nickel from the Monel; sulfur from the corrosion product; and carbon from the hydrocarbons in the process stream. The differences in the results for Scales 1 and 2 are not considered to be significant. 
Table IX. Chemical composition (weight precent) of scale found behind the Monel liner.

\begin{tabular}{llcl} 
& Element & Scale 1 & Scale 2 \\
\hline Emission Spectroscopy & $\mathrm{Al}$ & 0.05 & 0.05 \\
& $\mathrm{Ca}$ & $<0.05 \mathrm{~T}$ & $0.05 \mathrm{~T}$ \\
& $\mathrm{Cr}$ & 0.05 & 0.05 \\
& $\mathrm{Cu}$ & 2 & 2 \\
& $\mathrm{Fe}$ & $>20$ & 0.01 \\
& $\mathrm{Mg}$ & 0.01 & 1 \\
& $\mathrm{Mn}$ & 1 & 0.1 \\
& $\mathrm{Na}$ & 0.1 & 2 \\
& $\mathrm{Ni}$ & 2 & 0.2 \\
& $\mathrm{Si}$ & 0.2 & $14 \pm 2$ \\
\hline
\end{tabular}




\section{Summar y Comments}

Tests to evaluate the susceptibility of the vessel materials to corrosion and hydrogen cracking indicated that:

1. The steels used for Courses 1, 2, and 3 were all susceptible to hydrogen pressure cracking in a hydrogen-charging environment.

2. The vessel steels and the repair welds were not susceptible to stress corrosion cracking in an $\mathrm{MEA} / \mathrm{H}_{2} \mathrm{~S}$ environment.

3. The galvanic corrosion tendencies between the steel and the Monel liner were insignificant.

4. Hydrogen-induced cold cracking could have occurred in the HAZ of Course 1 at the time Course 2 was replaced; however, this mechanism of cracking does not account for the extensive cracking observed in the vicinity of the repair welds. 
FRACTURE SURFACE OBSERVATIONS

The most important pieces of evidence in many failure investigations are the fracture surfaces. The examination of fracture surfaces can often reveal where the fracture began, the nature and size of the initial defect that triggered the fracture, the path and direction of propagation, and the relative fracture resistance of the material. This was indeed the case for the present investigation.

Information Received from the Fire Marshal's Investigation

The investigation by NBS significantly benefited from the FMI on the same vessel pieces [1]. As the first step of the investigation, three NBS metallurgists visited Packer Engineering and carefully reviewed their findings with emphasis on the fracture surface observations. This was an obvious first step for practical reasons, but it was also important for a fundamental technical reason. The FMI began more than one year before NBS received the vessel pieces. During this period, the fracture surfaces deteriorated due to corrosion, and some portions of the surface were removed for the FMI studies.

Fortunately, a photographic record in color of the fracture surfaces in both the original condition and after cleaning was available to NBS from the FMI. The photographs were taken at $150 \mathrm{~mm}$ ( $6 \mathrm{in.}$ ) intervals around the circumference before any specimens were removed from the fracture surface.

Areas of black deposit were visible on the photographs of the Ring 2 fracture surface. These deposits were analyzed in the FMI and found to be rich in sulfur [1]. The source of the sulfur was assumed to be the $\mathrm{H}_{2} \mathrm{~S}$ in the pressure vessel. Thus, FMI concluded that the deposits delineated cracks that existed in the vessel prior to the catastrophic fracture. The black deposits indicated that pressure vessel 12D701 was cracked to depths exceeding half its wall thickness over nearly $40 \%$ of its circumference.

Photographs of the Ring 1 fracture surface did not reveal the black deposits, presumably because the deposit was oxidized during the fire. Two sets of color photographs made from the original negatives of the cleaned fracture surfaces (Rings 1 and 2) were obtained, assembled into montages of both fracture surfaces, and used by NBS in the present investigation. 
The metallographic and scanning electron microscopy (SEM) studies of the FMI were also reviewed by NBS. Copies of the photographs taken to document the fractographic studies were obtained by NBS. These were of particular interest because the condition of the fracture surfaces may have deteriorated between the time of these studies and the start of the NBS investigation.

Metallurgists at NBS carefully reviewed the FMI. The observations and interpretations made by NBS personnel on the photographs from the FMI are part of this study.

\section{Visual Observations}

Upon receipt of the pressure vessel pieces, the fracture surfaces were visually examined in the original condition with the unaided eye and with a low-power (up to $35 \mathrm{X}$ ) optical microscope. The surfaces were covered with an adherent, dark, rustlike layer that obscured many of the features. However, several notable features were apparent. For about $80 \%$ of the circumference, the fracture occurred in Course 1 adjacent to Weld 1/2, i.e., in HAZ 1. The remainder of the fracture path was on the other side of Weld $1 / 2$, in HAZ 2, except for a $0.6 \mathrm{~m}$ (2 ft.) portion where the crack deviated away from Weld $1 / 2$ and into Course 2. In the region where the fracture path was confined to the HAZ, the fracture surface had a fibrous (sometimes called woody) appearance at low magnifications, and there was no evidence of the chevron markings characteristic of brittle fracture or of the shear lips characteristic of ductile fracture. Additional observations were made after the fracture surfaces were cleaned with high pressure steam and by scrubbing with brushes and detergent. Examination of the fracture surface of Ring 2 revealed the black deposits on the fracture surface were readily visible, but the contrast was not as sharp as on the FMI photographs.

The fracture surface of Ring 2 was examined with an optical microscope in the regions corresponding to those where the black deposits were found on the mating fracture surface. The deposits had a reddish color. When a sharp probe was used to dig into the surface deposits, the red color became even more apparent. Presumably, the black deposits reacted with oxygen and became a red oxide of iron during the fire. 
The montage of the Ring 2 fracture surface was the principal means of locating and sizing the regions on the fracture surface that were covered with a black deposit. On the basis of the findings of the FMI, we assumed that the black deposits delineated cracks that existed in the vessel prior to the catastrophic rupture. These are referred to as pre-existing cracks. The location and length of the pre-existing cracks are summarized in Figure 28. The crack depths are not indicated in this figure because of uncertainties in the depth measurement.

One of the pre-existing cracks was located between CC $7.4 \mathrm{~m}$ and CC $8.2 \mathrm{~m}$. The depth of this crack exceeded $80 \%$ of the wall thickness over most of its length and exceeded $90 \%$ of the depth for about half its length. The location of this crack coincided with the location of the leak, as reported by the eyewitness, i.e., between the ladder (CC $6.7 \mathrm{~m}$ to CC $7.2 \mathrm{~m}$ ) and the inlet valve (CC $8.3 \mathrm{~m}$ ) at the approximate level of the valve (the level of Weld 1/2). The location reported by the eyewitness is considered reliable because the vapor plume from the leak interfered with his efforts to climb the ladder and close the valve at the time of the leak. Thus, we assumed that the catastrophic rupture initiated at this crack.

In addition to locating the regions of pre-existing cracks, Figure 28 summarizes the observations regarding the paths and directions of fracture propagation. These observations were made directly on the fracture surfaces of Rings 1 and 2. The crack that initiated the fracture, referred to as the initiation, was $800 \mathrm{~mm}$ (31 in.) in length and was in HAZ 1 between CC $7.4 \mathrm{~m}$ and CC $8.2 \mathrm{~m}$. The fracture propagation from the CC $7.4 \mathrm{~m}$ end occurred along $\mathrm{HAZ}$ 1. It temporarily jumped into HAZ 2 between $\mathrm{CC} 4.3 \mathrm{~m}$ and $\mathrm{CC} 3.9 \mathrm{~m}$ and aga in between CC $3.1 \mathrm{~m}$ and CC $2.5 \mathrm{~m}$. At the locations where the fracture jumped out of HAZ 1 (CC $4.3 \mathrm{~m}$ and CC $3.1 \mathrm{~m}$ ), the fracture tunneled a short distance under Weld $1 / 2$ along HAZ 1 . This suggests that the crack was propagating in the counterclockwise direction (see Figure 28) and continued in this direction for a short distance beyond the place where it jumped to HAZ 2. A similar indication of counterclockwise propagation was observed at CC $2.75 \mathrm{~m}$, where the crack veered upward through Weld $1 / 2$ into Course 2 . The path of the fracture within Course 2 was clearly delineated by chevron markings that pointed to the origin. It propagated through course 2 in the 


\section{POSITION, meters}

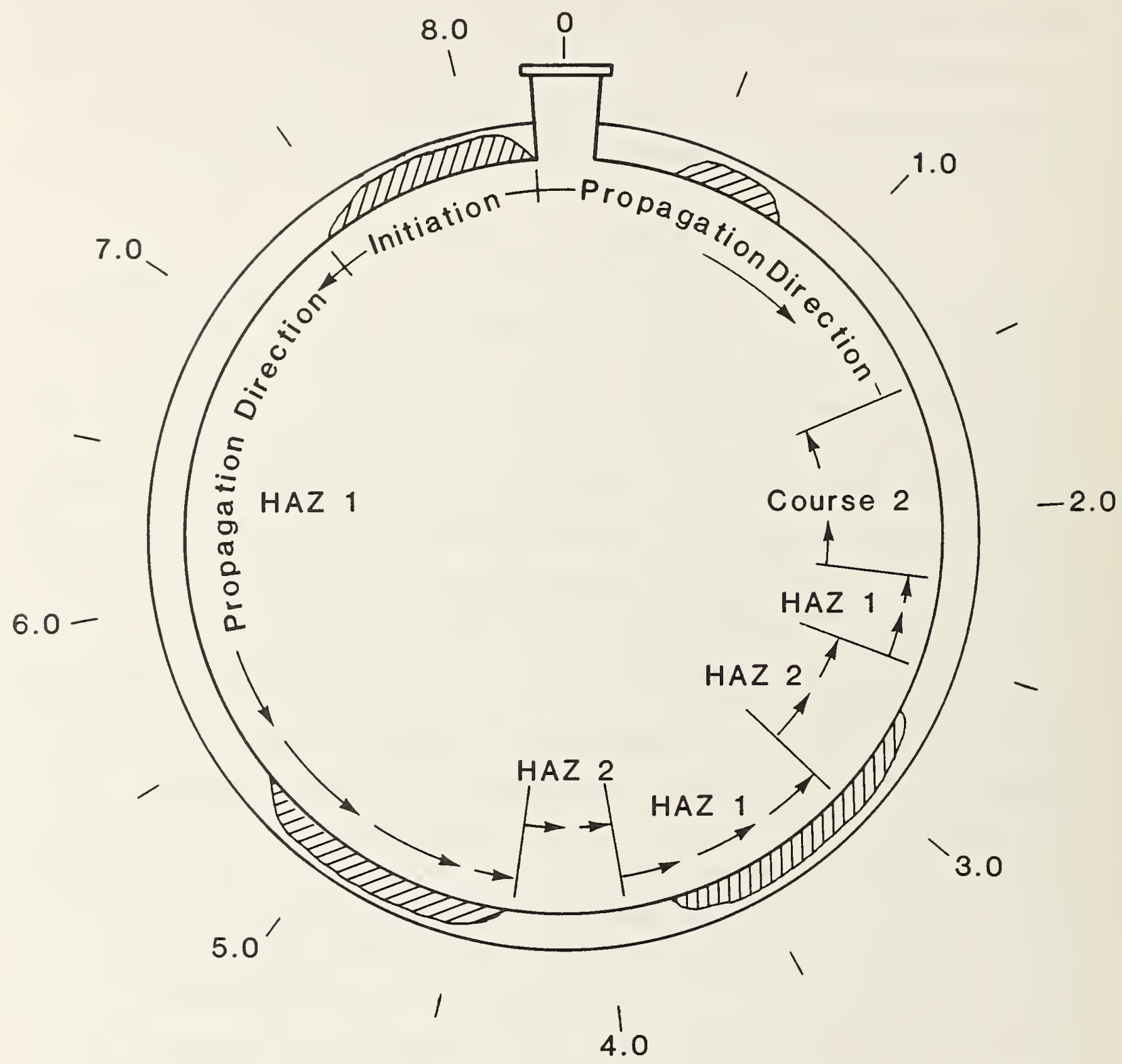

Figure 28. Sketch of fracture surface showing pre-existing cracks (shaded areas), fracture path, and direction of fracture propagation. 
counterclockwise direction until the CC $1.5 \mathrm{~m}$ position, where it connected to the crack coming from the other direction. A small piece of the vessel was mlssing at this location. It is assumed that the piece broke free when the two cracks, which were traveling in opposite directions, connected. The rracture propagation from the CC $8.2 \mathrm{~m}$ end may have been temporarily pinned by the reinforcement for the hydrocarbon inlet piping. After passing around the reinforcement, the crack propagated from CC $0.1 \mathrm{~m}$ to $\mathrm{CC} 1.5 \mathrm{~m}$ through HAZ 1 .

During the final stages of fracture, the vessel started to tip over and plastically strained the remaining material that was located in the vicinity of CC $1.5 \mathrm{~m}$. This can be seen from the opened cracks on the inside surface of the piece cut at CC $1 \mathrm{~m}$ (Figure 29) and on the inside surface of a piece cut at CC $1.5 \mathrm{~m}$ where the fracture passed through Course 2 above Weld $1 / 2$ (Figure 30). Metallography of the plastically stretched cracks taken from these pieces is shown in Figures 11 and 17.

The path of propagation was unusual in two respects: 1) Fracture occurred perpendicular to the axial stresses rather than perpendicular to the hoop stresses, which are twice the magnitude of the axial stresses. 2) The fracture path was confined to a path near the HAZ for over $90 \%$ of the circumference. Normally, once a fracture begins to run, it has sufficient strain energy to follow a more arbitrary path.

The fracture initiated perpendicular to the axial stresses because the initiation was a very large crack ( $800 \mathrm{~mm}, 31 \mathrm{in.})$ that was oriented perpendicular to the axial stress. In the MPI, all crack indications longer than $25 \mathrm{~mm}$ ( 1 in.) were along the HAZ of the circumferential welds (Welds $1 / 2$ and 2/3). In comparison, the vertical welds and their HAZs (in Rings 1,2 , and 3) had relatively few crack indications.

The crack was confined to the HAZ of the circumferential welds because it was a low energy fracture. There was essentially no shear lip formation at the crack border until the final stage of cracking; shear lips developed when the crack veered up into Course 2. The plate orientation was such that the minimum toughness path was in the circumferential direction. The Charpy toughness results indicated that the weld metal toughness (160 J, $124 \mathrm{ft} \cdot \mathrm{lbf}$ ) was considerably higher than the HAZ toughness (70 J, $54 \mathrm{ft} \cdot 1 \mathrm{bf}$ ). Thus, deviation from the HAZ was energetically unfavorable. 


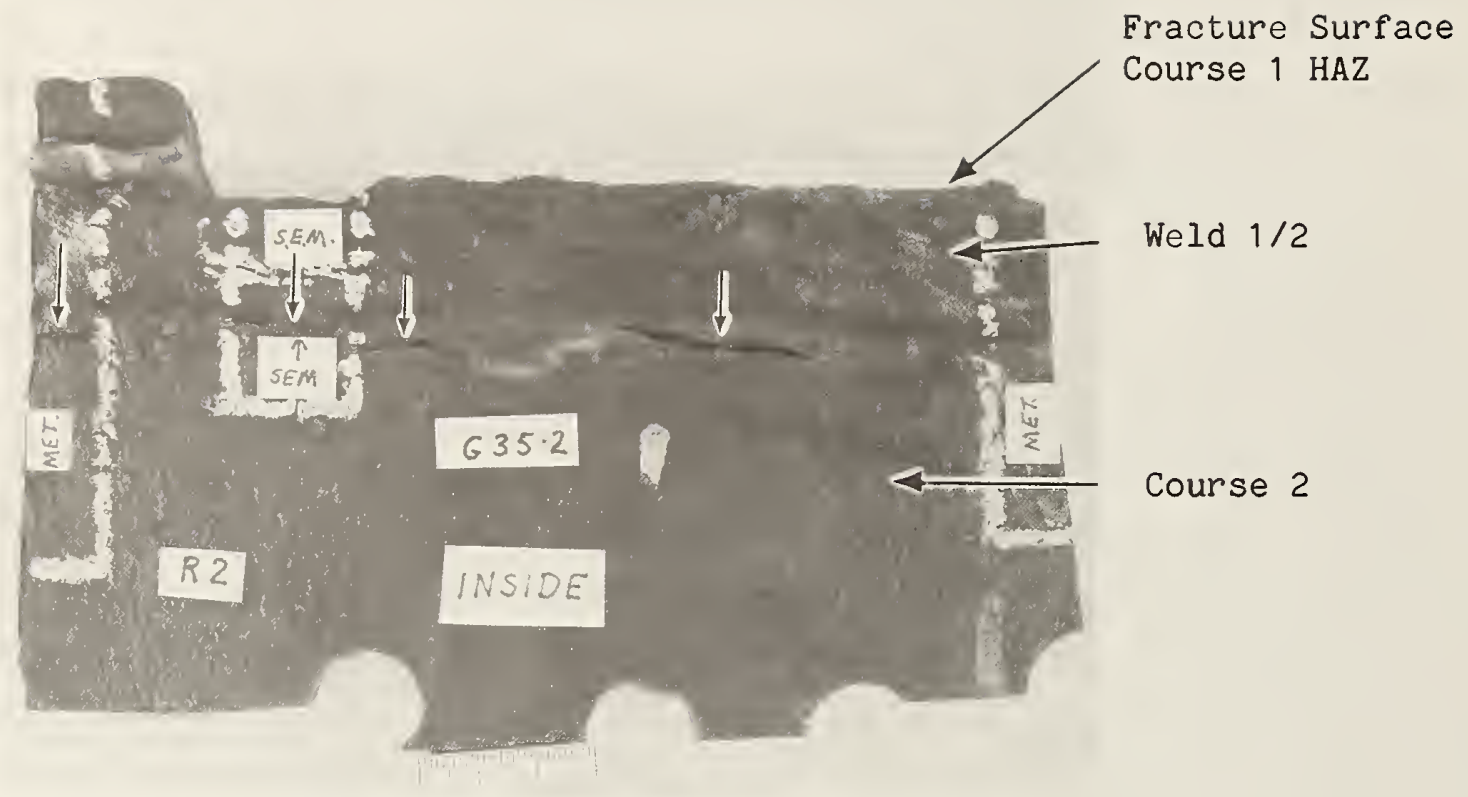

Figure 29. Section of fracture removed for metallographic studies with arrows showing cracks on inside surface of HAZ 2 . 


\section{Metallography}

Metallography was used to investigate the nature of crack initiation, subcritical growth through the thickness, and propagation around the circumference.

The metallographic studies of the FMI were extremely informative. The sections of particular interest were those through the fracture surface in regions of black deposit. Etched cross sections of the mating fracture surfaces were taken at each location (Plates 44, 51, 58, and 62 in the FMI report [1].) In reviewing these cross sections as part of the present study, we noted that in each case, the crack intersected the inside surface in the HAZ, close to the fusion line. The crack made a straight trace through the HAZ, typically 1 to $2 \mathrm{~mm}$ ( 0.04 to $0.08 \mathrm{in}$ ), and then $\mathrm{z}$ igzagged through the base metal to about the midthickness level. It then entered the HAZ and propagated through the HAZ or the weld metal to the outside surface.

The area on the fracture surface identified as the initiation in Figure 28 was examined metallographically and the observations were compared with those made on the FMI specimens. Two etched sections taken through the initiation at the $\mathrm{CC} 7.4 \mathrm{~m}$ and $\mathrm{CC} 7.6 \mathrm{~m}$ locations are shown in Figure 31 . Note that in both cases the crack passed through the HAZ at the inside surface, propagated through the base metal near the HAZ for most of the thickness, and passed through the weld at the outside surface. In the specimen at CC $7.4 \mathrm{~m}$ (Figure $31 \mathrm{~b}$ ), the crack intersected the surface in the HAZ near the fusion line, the location expected on the basis of the FMI metallography and consideration of microhardness. However, the specimen at CC $7.6 \mathrm{~m}$ (Figure $31 \mathrm{a}$ ) was slightly different. The crack intersected the inside surface in the HAZ about $1 \mathrm{~mm}$ ( $0.04 \mathrm{in.}$ ) away from the fusion line. The Knoop microhardness measured adjacent to the crack ranged from 209 to 251 (HK 500), a hardness level deemed not susceptible to crack initiation. Thus, crack propagation along (or to) the surface may have occurred.

Several long cracks were detected in the HAZ of Weld $2 / 3$ above the initiation site in Weld 1/2. Metallographic sections were taken through the cracks at CC $7.6 \mathrm{~m}$ (Figure 32) and at CC $5.9 \mathrm{~m}$ (Figure 33). These cracks were examined metallographically and then broken open to expose the fracture surface for fractographic examination. In both cases, a black deposit was 


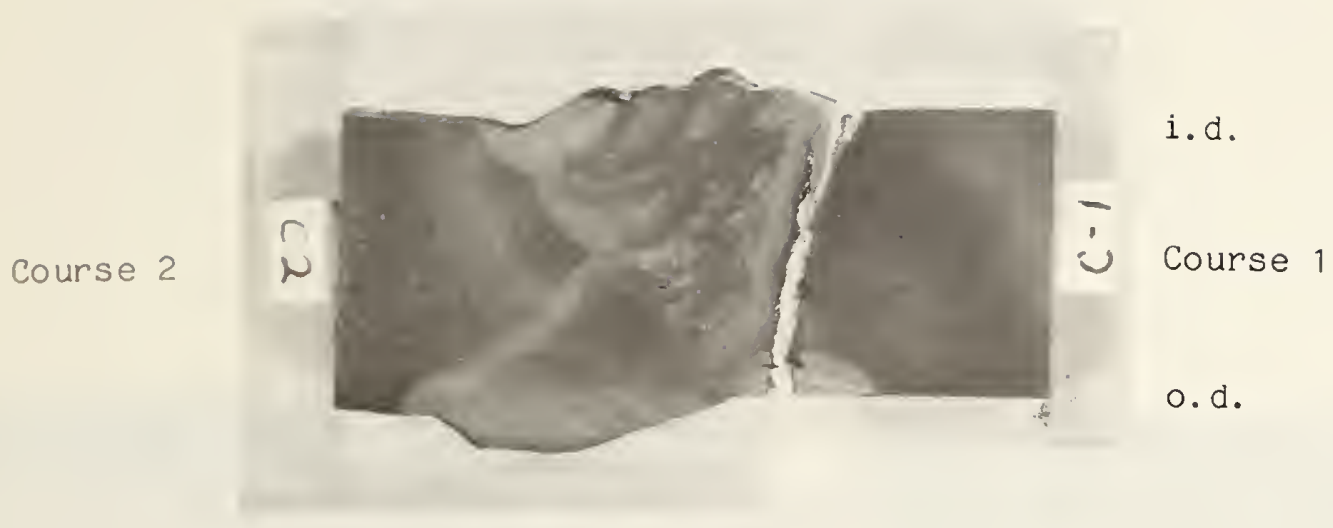

a. Section at CC $7.6 \mathrm{~m}$

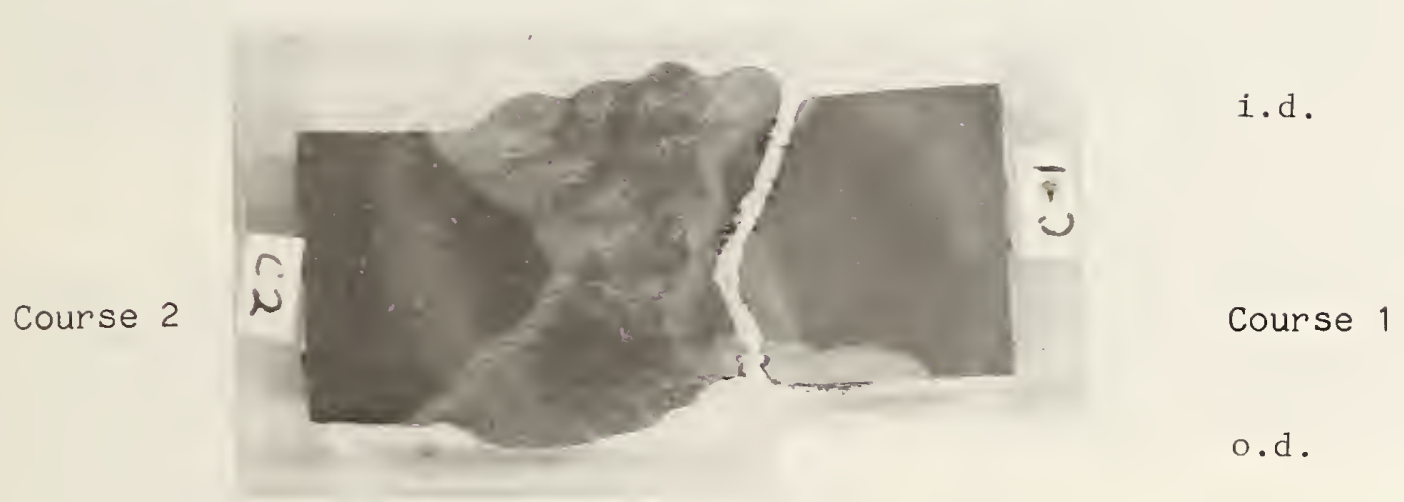

b. Section at CC $7.4 \mathrm{~m}$

Eigure 31. Metallographic sections through the fracture surface at the location of the initiation crack. 


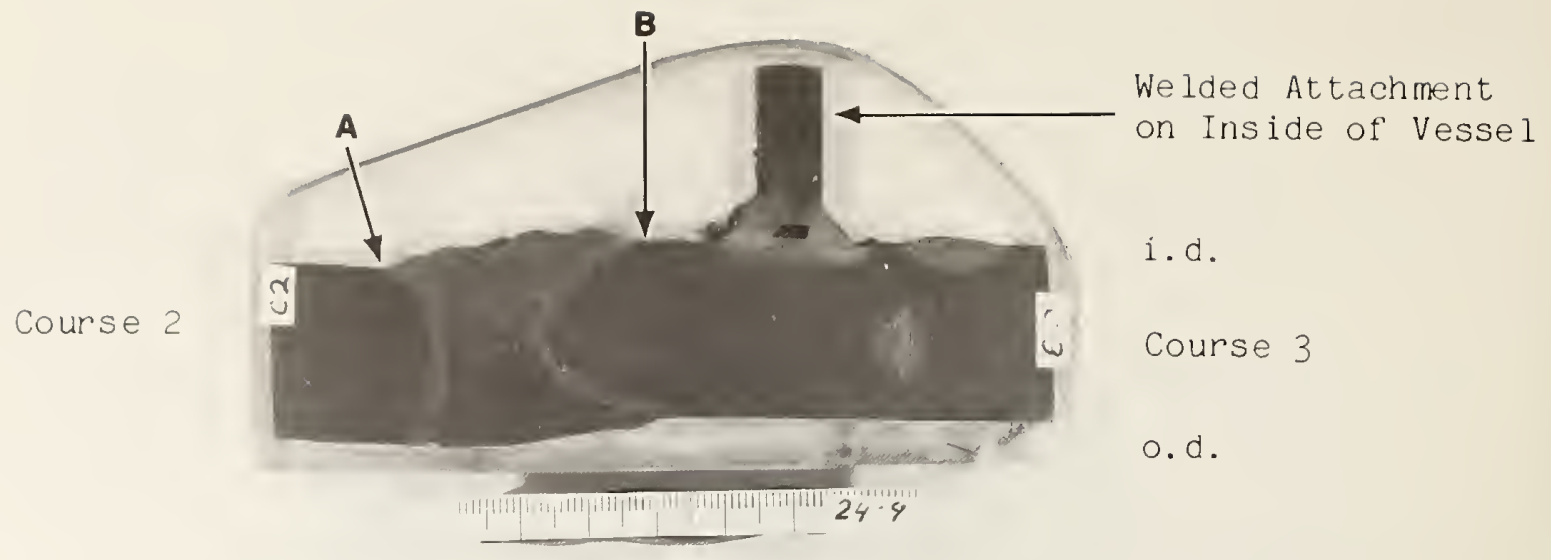

a. Macrostructure of Weld $2 / 3$ at CC $7.6 \mathrm{~m}$

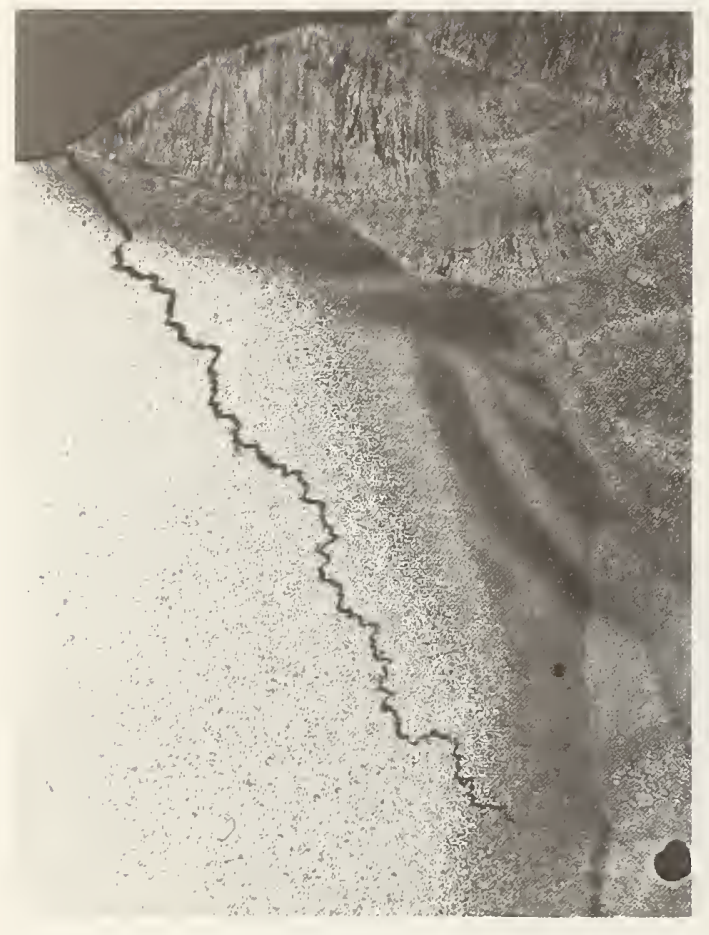

b. Crack in HAZ ?

at location A

in Figure $32 a$

$1 \mathrm{~mm}$

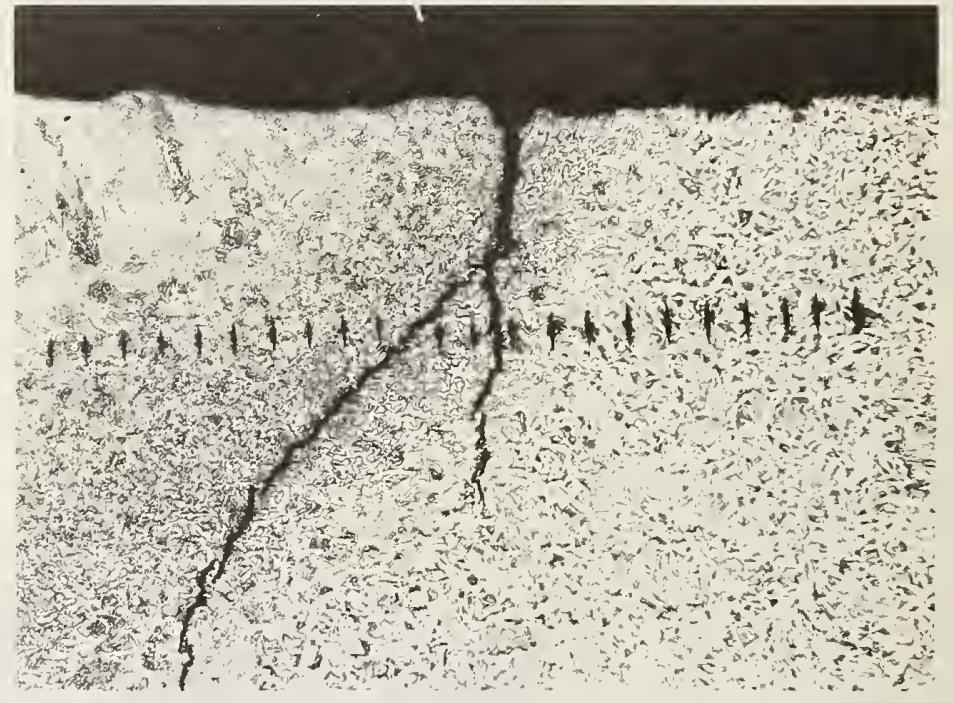

c. Crack in HAZ 3 and microhardness $\overline{200 \mu \mathrm{m}}$ indentations at location $B$ in Figure $32 a$

d. Knoop hardness values (HK 300) (tracing of Fig. 32c)

Figure 32. Microstructure of Weld $2 / 3$ at CC $7.6 \mathrm{~m}$, metallography of cracks in $\mathrm{HAZ} 2$ and $\mathrm{HAZ} 3$, and microhardness of HAZ 3. 


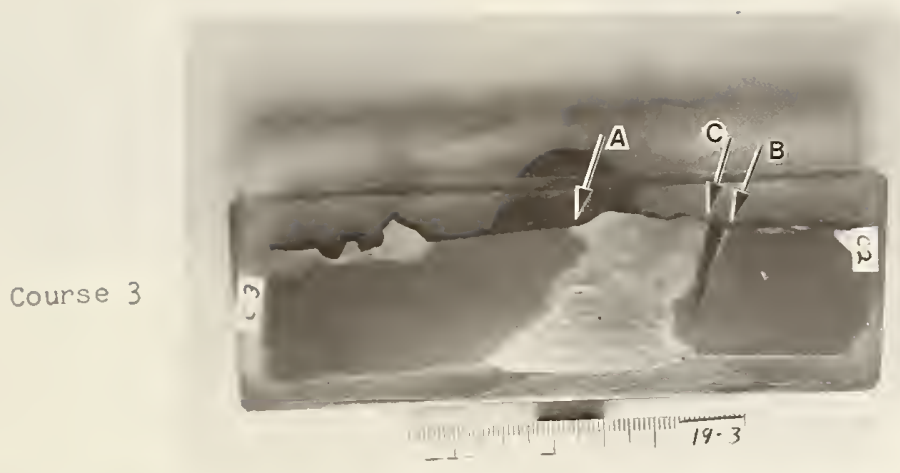

i. d.

Course 2

o.d.

a. Macrostructure of Weld $2 / 3$ at CC $5.9 \mathrm{~m}$

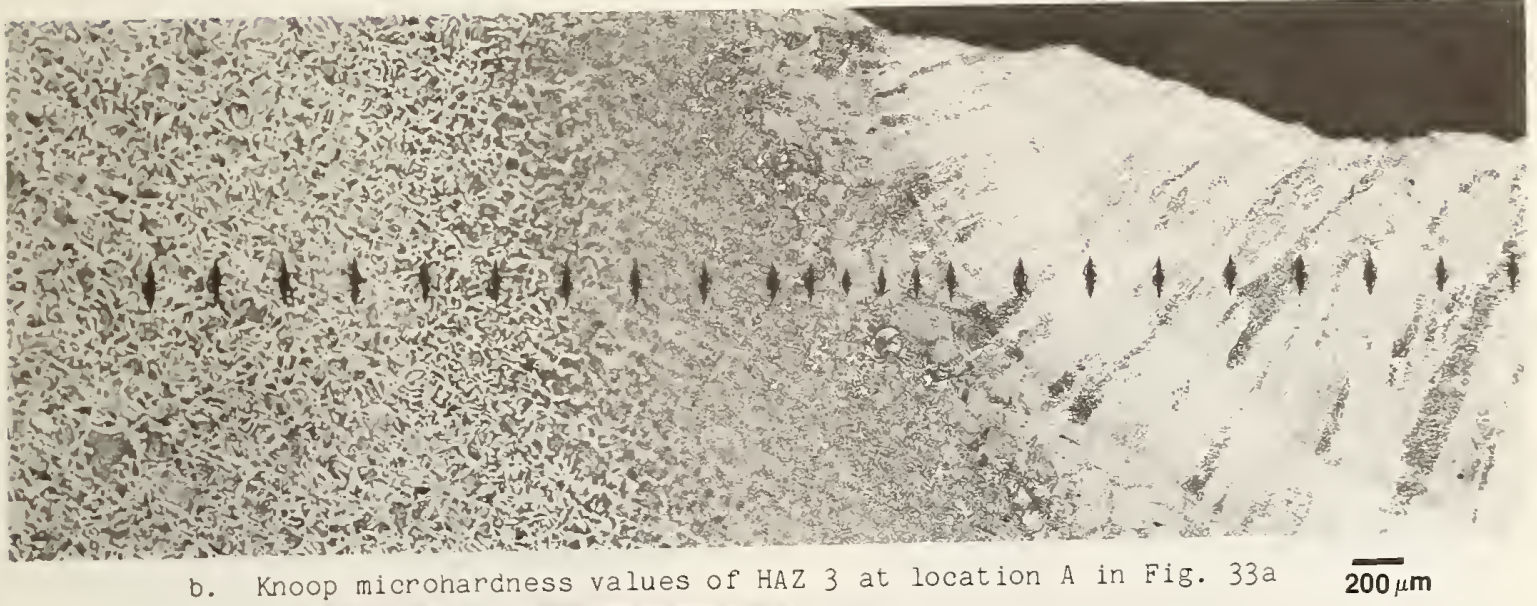

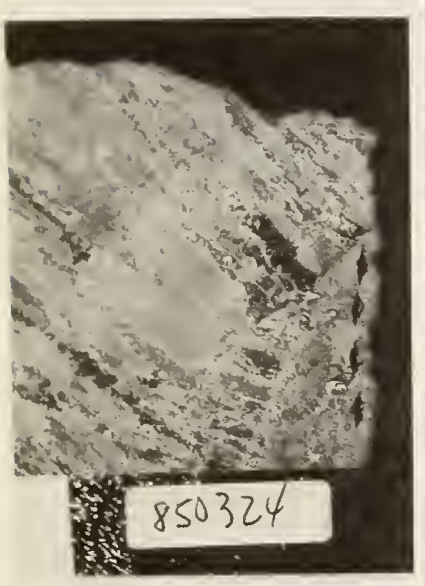

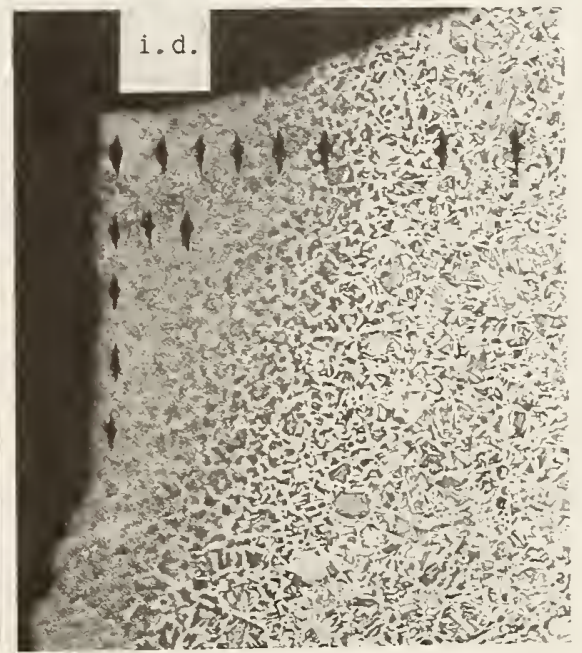

c. Knoop hardness indentation of HAZ 2 at locations $B$ and $C$ in Figure $33 a$

$\overline{200 \mu m}$

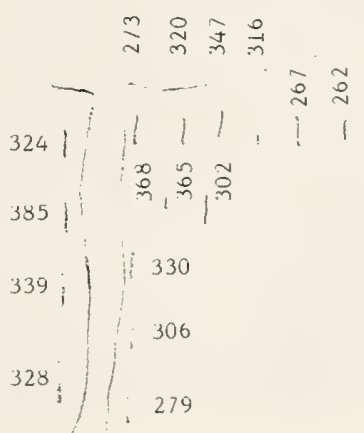

d. Knoop hardness values (HK300) at locations $B$ and $C$ (tracing of 5 ig. 33c)

Eigure 33. Macrostructure of weld $2 / 3$ at CC $5.9 \mathrm{~m}$ and microhardness values of $\mathrm{HAZ} 2$ and HAZ 3. 
found on the crack surfaces that was similar to the deposit found on the Ring 2 fracture surface. Thus, black deposits did form on cracks open to the inside of the vessel. This supports the idea that the black deposits on the fracture surface indicated cracks that existed at the time of the fracture.

The crack in HAZ 2 of Weld $2 / 3$ at CC $7.6 \mathrm{~m}$ (Figure $32 \mathrm{~b}$ ) had the same features observed in sections taken through regions of black deposit on the fracture surface. The crack intersects the surface at the fusion line, runs in a straight line through the $\mathrm{HAZ}$, and then $\mathrm{zigzags}$ through the base metal to about the midthickness level, where it stops in the HAZ.

The crack in HAZ 2 of weld $2 / 3$ at CC $5.9 \mathrm{~m}$, propagated through the HAZ for nearly $10 \mathrm{~mm}(0.4 \mathrm{in.})$, yet it had the same key features observed in the other specimens. The crack intersected the surface near the fusion line and had straight edges while located in the hardened part of the HAZ. Microhardness indentations along this straight edge are shown in Figure 33c. When it propagated through the HAZ that had been tempered by a subsequent pass, it changed to the zigzag mode and continued in this mode into the base metal.

Several sections were taken through the fracture surface to determine the path of the fracture in locations that were not marked by a black deposit, i.e., whether the crack was located in the HAZ or in the base metal near the HAZ. In general, the crack path included some HAZ near the surface, but most of the crack front passed through the base metal. This can been seen from the sections taken from weld $1 / 2$ at CC $1.0 \mathrm{~m}$ shown in Figure 15 and from Weld $1 / 2$ at CC $1.3 \mathrm{~m}$ and Course 1 at CC $5.7 \mathrm{~m}$ shown in Figure 34 . Thus, the path of the catastrophic fracture is more correctly described as be ing near the HAZ rather than through the HAZ.

\section{Fractography}

The fracture surfaces were examined with a scanning electron microscope (SEM) in an effort to identify the micromodes of fracture of the initial defect and the propagating crack. In addition, cracks detected near weld $2 / 3$ were broken open and examined to clarify the mechanism of crack formation.

It was not possible for NBS to conduct meaningful SEM studies of the vessel's fracture surface because we could not clean the fracture surfaces without damaging the microscopic features. However, the low magnification (X10) 


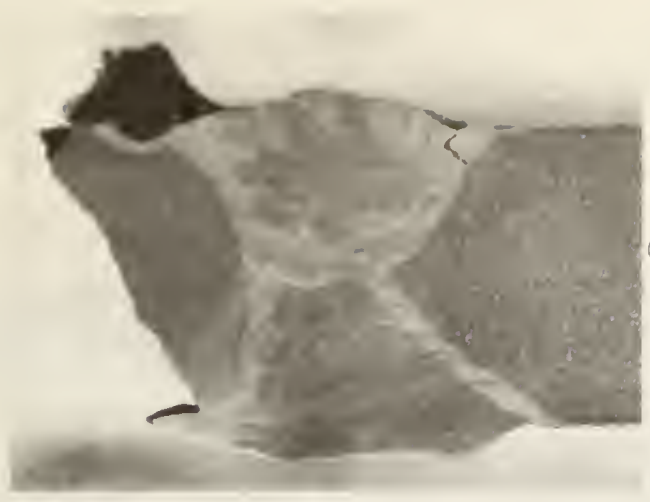

i.d.

o.d.

Macmosiructum of Weld $1 / 2$ at CC $1.3 \mathrm{~m}$

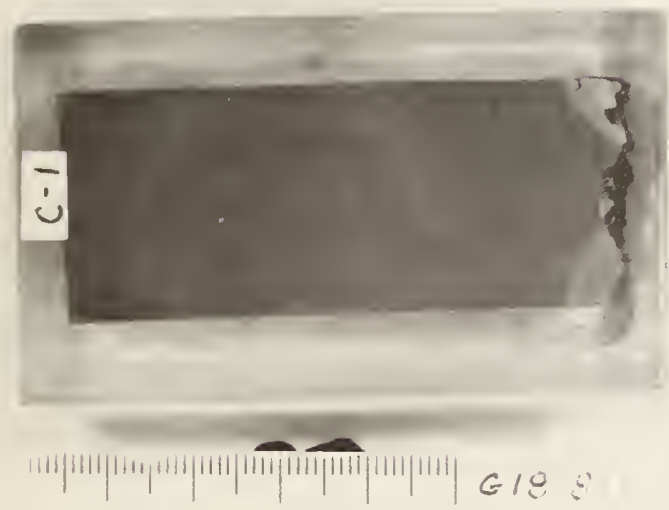

c. Macrostructure of Course 1 at CC $5.7 \mathrm{~m}$

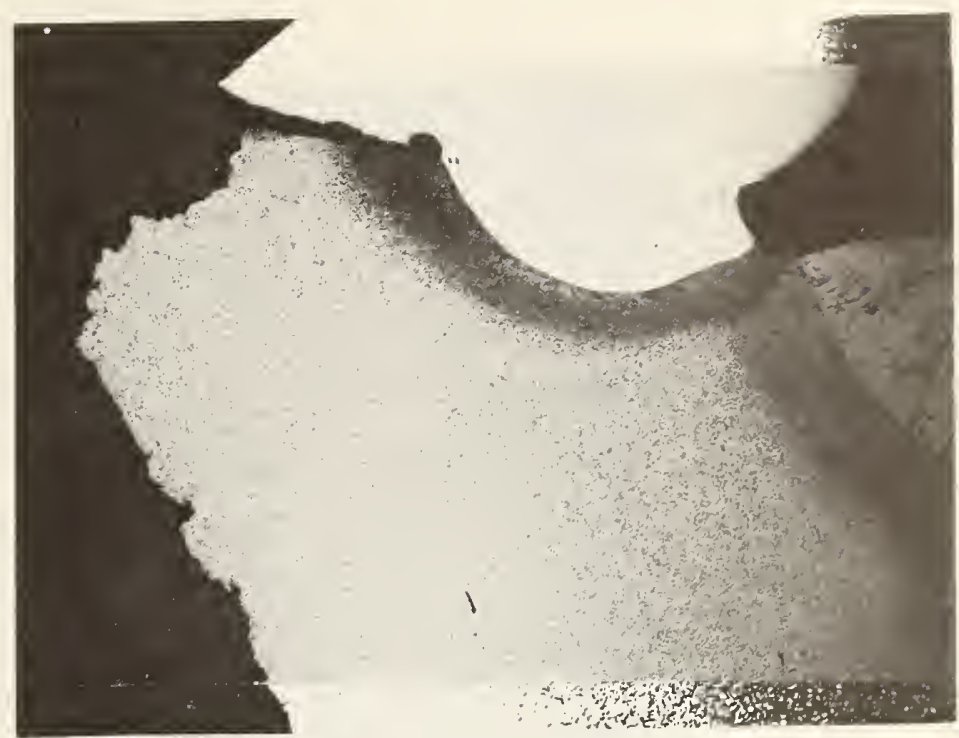

b. Enlargement of Eigure $34 \mathrm{a}$ at inner surface

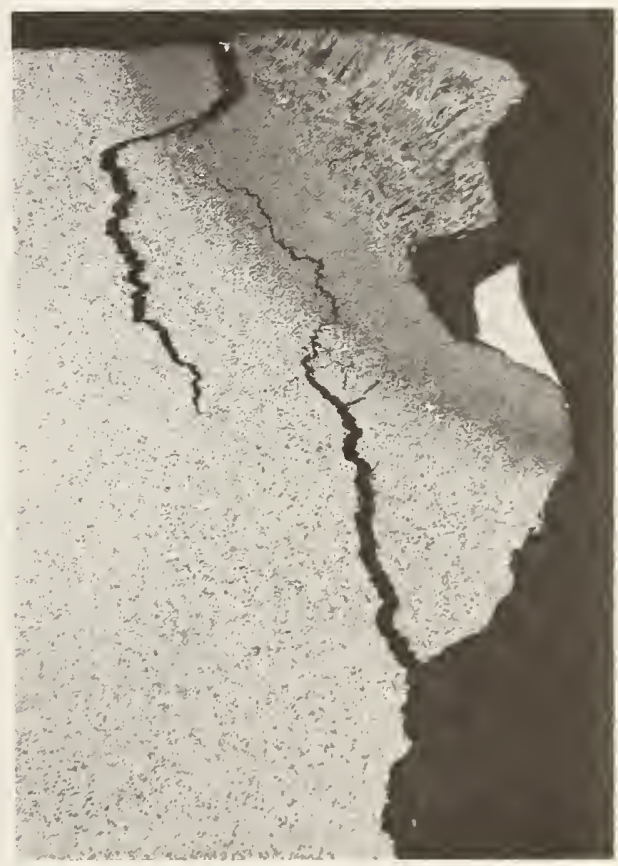

$1 \mathrm{~mm}$

d. Enlargement of Figure $34 \mathrm{c}$ at inner surface

Figure 34. Macrostructures at two locations where a black deposit was not found on the fracture surface. 
fractographs from the FMI were quite informative and two representative samples, PE 103 (CC $5.2 \mathrm{~m}$ ) and PE 114 (CC $7.3 \mathrm{~m}$ ), are discussed below.

The metallographic section and corresponding fractograph of specimen PE 103 are shown in Figure 35. This specimen was taken at CC $5.2 \mathrm{~m}$ in a region of black deposit. The metallographic section has the characteristic appearance discussed previously: a straight-sided crack intersecting the surface in the HAZ near the fusion line and beginning a zigzag path through the base metal about $1.5 \mathrm{~mm}$ ( $0.06 \mathrm{in}$ ) below the surface. The fractograph clearly shows the transition from a straight-sided crack in the HAZ to fibrous (zigzag) texture at a depth of $1.5 \mathrm{~mm}(0.06 \mathrm{in.})$. In this case the final fracture passed through the weld, and a marked transition from fibrous to uniform fracture texture can be seen on the fractograph. Examination of the fractographs from the FMI at higher magnification in the region of uniform texture indicates that the fracture mode through the weld was ductile-dimple fracture.

The metallographic section and corresponding fractograph of specimen PE 114 are shown in Figure 36. This specimen was taken at CC $7.3 \mathrm{~m}$ in a region free of the black deposit. The metallographic section shows that the fracture passed through the $\mathrm{HAZ}$ and base metal. The fracture intersects the inside surface in the HAZ near the fusion line and the fibrous texture is somewhat finer near the surface. Yet, the distinct change in texture noted in specimen PE 103 was not apparent.

The cracks near weld $2 / 3$ were thought to be similar to the ones existing in Weld $1 / 2$ except that they had not been exposed to fire and corrosion by the vessel fracture. Thus, we expected that there would be less corrosion damage on these crack surfaces and that improved fractographic observations could be made.

The crack in weld $2 / 3$ at CC $7.6 \mathrm{~m}$ was located directly above the initiation site and is thought to be equivalent to the pre-existing cracks near Weld 1/2. This crack, shown in Figure 32b, was broken open at room temperature to expose the fracture surface for SEM studies. There was a heavy, loose black corrosion product near the inside vessel surface, but the end of the crack had a very thin black deposit. This region was examined by SEM, and the fractographic features of the crack were compared with the features of 
i. d.

Course 1

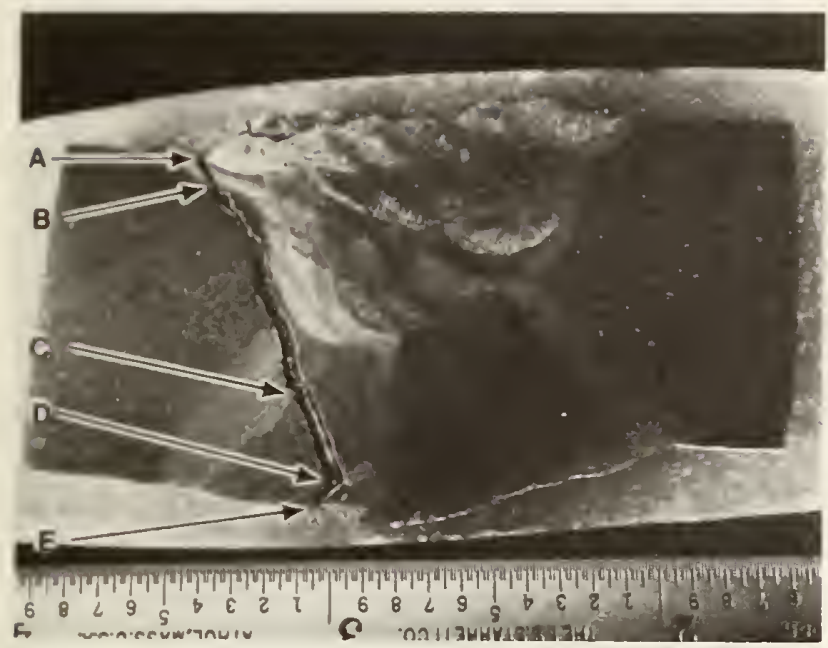

a. Macrostructure of Weld $1 / 2$ at CC $5.2 \mathrm{~m}$
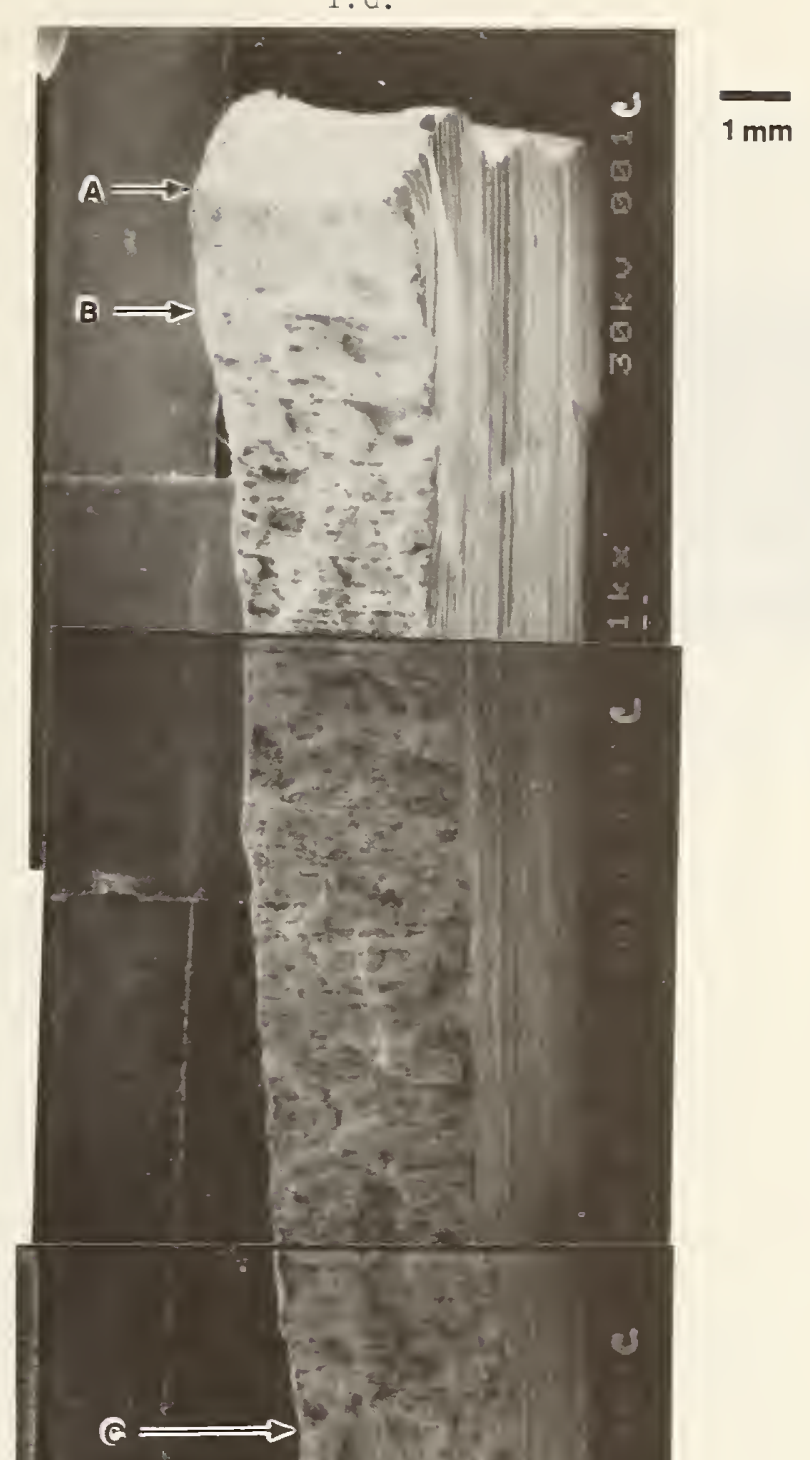

s)
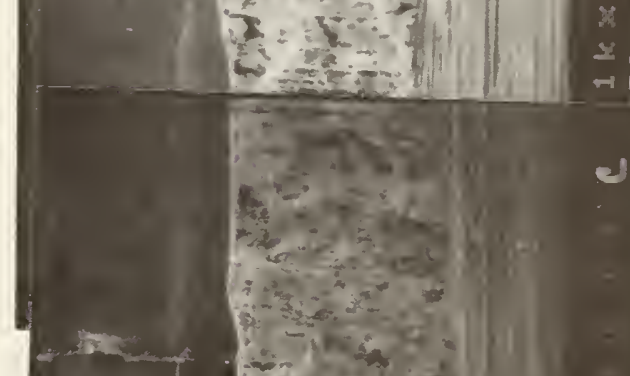

$\rightarrow$ i d)

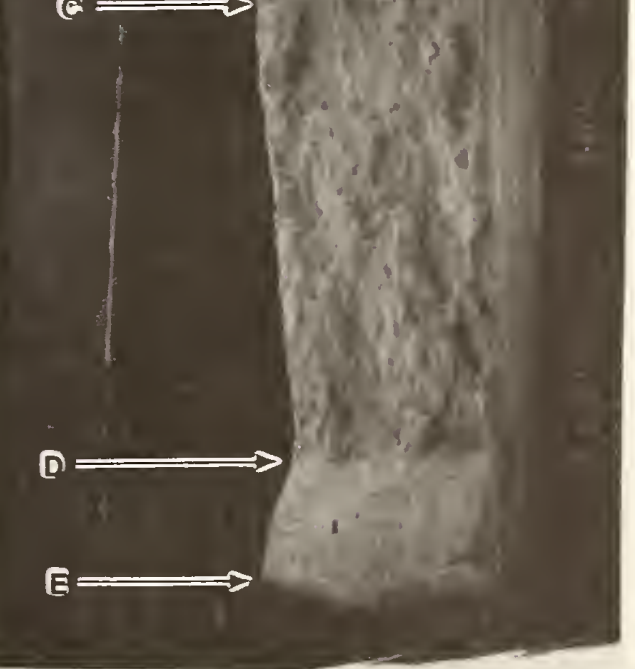

$\circ \cdot \propto$.

b. SEM fractograph of the fracture sunfa:e at the location shown in Figure 35 a

Eigure 35. FMI [1] photographs of the macrostructure of We $1 d 1 / 2$ and

fractograph at CC $5.2 \mathrm{~m}$. The letters show corresponding arnas. 
i. d.

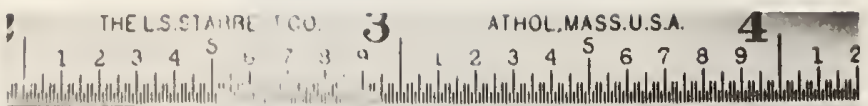

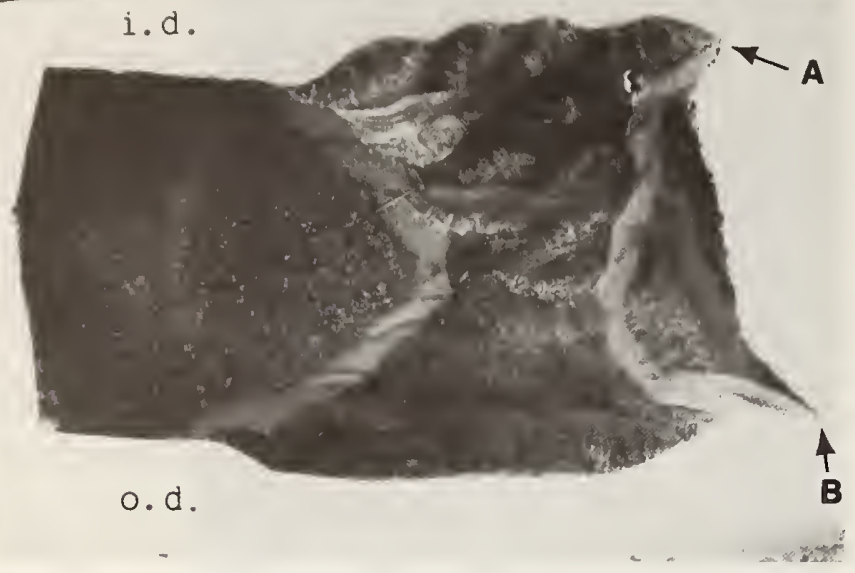

a. Macrostructure of Weld $1 / 2$ at CC $7.3 \mathrm{~m}$

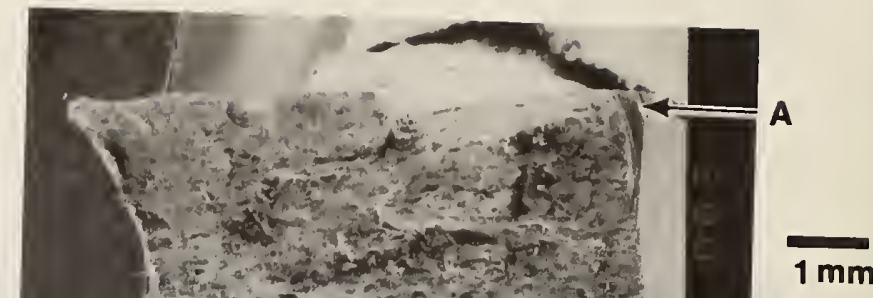

$\mathrm{m}$ 
the reshly exposed fracture surface created by breaking the crack open. At low magnifications, the features of this crack and the freshly exposed fracture are remarkably similar. In both cases, there are regions of dimples roughly aligned with the plate surfaces. At higher magnification, as shown in Figure 37, one can see dimpled regions separated by smooth areas often containing splits associated with inclusion stringers. On the freshly exposed fracture surface, the regions separating the rows of dimples have a rougher texture and there are fewer splits.

The fracture features on the crack surface shown in Figure 37 are characteristic of hydrogen pressure cracking. The smooth regions develop where the metal splits due to internal pressure developed by hydrogen that collected at the inclusion-matrix interface. These features are compared with fractographic observations made on a delamination induced in a Course 1 specimen by charging the specimen with hydrogen using the NACE solution (acidified seawater, $\mathrm{pH}=3$ ). The specimen was pulled apart to expose the surfaces of the delamination. Fractographic examination of the delaminated surface revealed smooth regions separated by cleavage facets, as shown in Figure 38. The similarity in the smooth regions of the delamination (Figure 38) and the crack (Figure 37) supports the contention that the subcritical crack growth observed in the pressure vessel was due to hydrogen pressure cracking.

\section{Microchemical Analysis of the Black Deposits}

Several samples of the fracture surface were removed from regions marked by the black deposit and used to identify the principal chemical constituents of the deposit. The samples were ground and polished perpendicular to the fracture surface and then analyzed by energy dispersive X-ray spectrometry and also by wavelength dispersive X-ray spectrometry. The results indicate that the black deposit is rich in sulfur. A report of the procedures and results is given in Appendix $F$. 


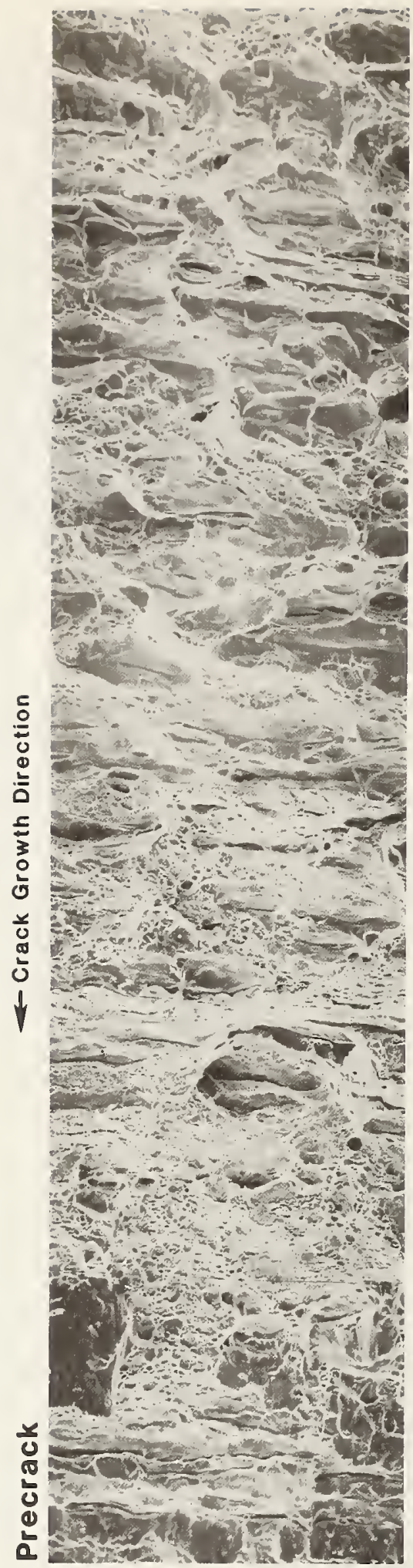

a. Fractograph of pre-existing crack that was originally covered with a black deposit

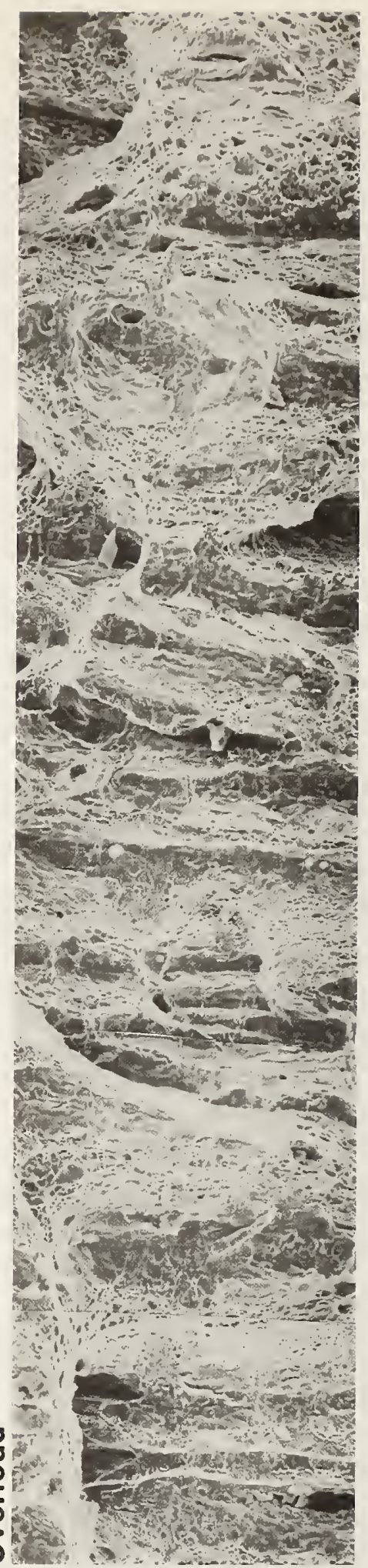

b. Fractograph of a freshly exposed surface (broken open in the laboratory)

Figure 37. Fractographs of the crack in HAZ 2 (shown in Figure 32) of We ld $2 / 3$ at CC $7.6 \mathrm{~m}$. 

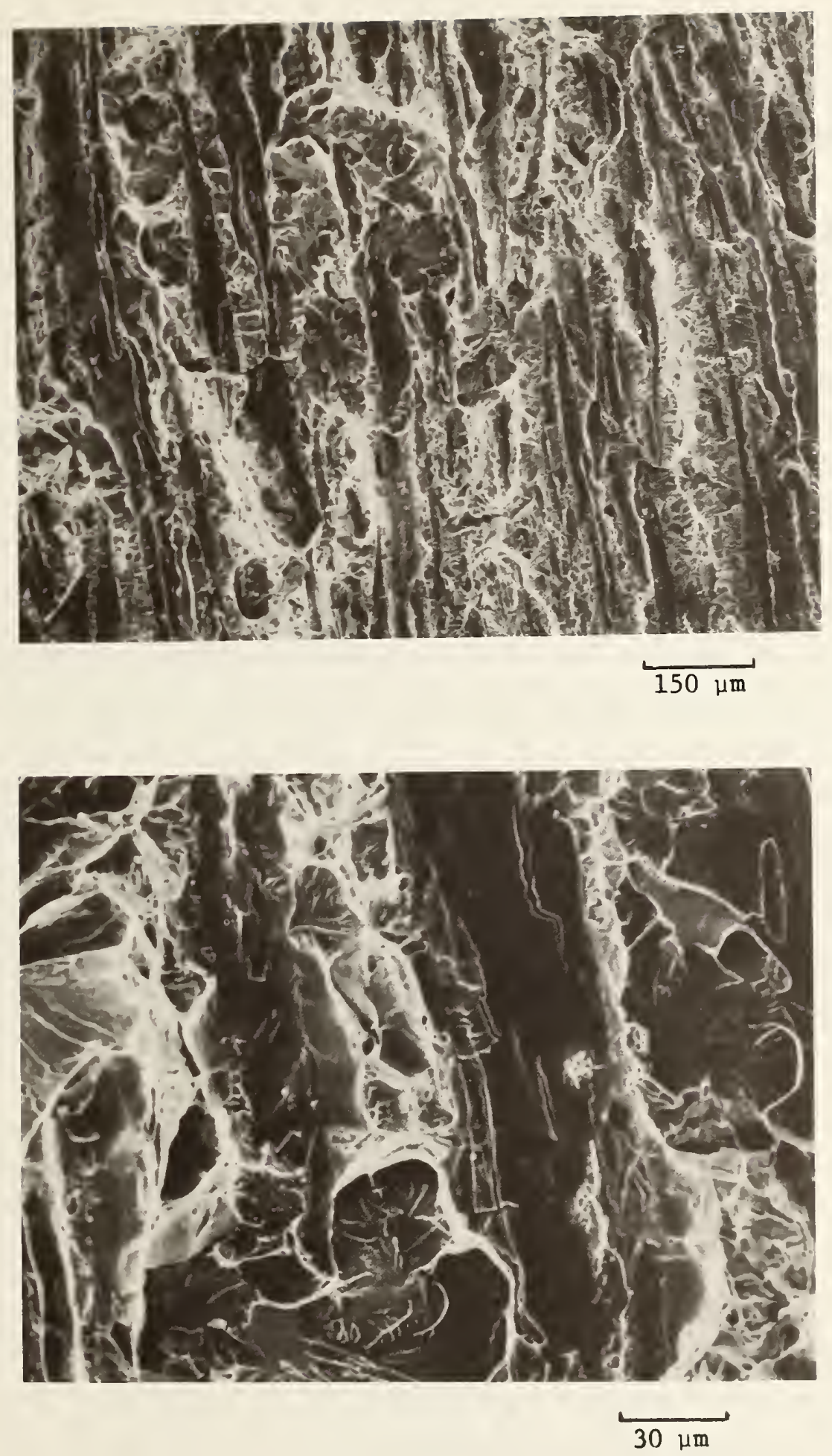

Figure 38. SEM fractographs of hydrogen pressure cracks in Course 1. 


\section{Summary Comments}

Metallurgical examination of the fracture surfaces and cracks found in We ld $2 / 3$ revealed:

1. Black deposits on the fracture surface delineated cracks that existed in the vessel prior to rupture. The cracks were open to the inside surface of the vessel and extended to depths beyond midthickness for almost $40 \%$ of the circumference.

2. A black deposit delineated an $800 \mathrm{~mm}$ long pre-existing crack in the $v$ ic inity of the leak that preceded rupture.

3. The fracture path was confined to the HAZ in Course 1 adjacent to the repair Weld $1 / 2$ for about $80 \%$ of the circumference.

4. The pre-existing cracks delineated by black deposits and similar cracks found in the HAZ of Weld $2 / 3$ initiated at the inside surface of the vessel adjacent to the field welds in regions of hard microstructure.

5. The pre-existing cracks initiated and followed a straight path through the hard part of the HAZ to a depth of 1 to $2 \mathrm{~mm}$. Crack initiation of this type is attributed to hydrogen stress cracking.

6. At a depth of 1 to $2 \mathrm{~mm}$, the cracks reached a softer microstructure and began to zigzag through the wall thickness. Crack propagation of this type is attributed to hydrogen pressure cracking. 
A fracture mechanics analysis was conducted to determine the role of stress, flaw size, and material properties in the vessel failure. The analysis was based on the crack tip opening displacement (CTOD) criterion, i.e., fracture occurs when the CTOD of a crack in the vessel exceeds the fracture toughness of the steel, which can also be expressed in terms of CTOD. The CTOD of a crack in the vessel is calculated using Irwin's equation [14]:

$$
\text { CTOD }=\frac{4}{\pi} \frac{K^{2}}{E \sigma_{y s}},
$$

where $K=\sigma \sqrt{\pi a} Y(a / \sqrt{R t})$,

$$
\begin{aligned}
\sigma & =\text { applied stress, } \\
a & =\text { half length of a through-thickness crack, } \\
R & =\text { radius of pressure vessel, } \\
t & =\text { thickness of the vessel steel at the location of the fracture, } \\
\sigma_{\mathrm{S}} & =0.2 \% \text { offset yield strength of the steel, } \\
\mathrm{E} & =\text { modulus of elasticity. }
\end{aligned}
$$

and

The parameters $R$ and $t$ are dimensional values known for the vessel, and $\sigma_{y s}$ and $E$ are material properties known for the vessel steel. The function $Y(a / \sqrt{R t})$ is the geometrical term used to calculate the stress intensity for a circumferential crack in a cylindrical shell [15]. The axial stress is readily calculated for the case of a pressure vessel operating at a known pressure:

$$
\sigma=\frac{p R}{2 t}=35 \mathrm{MPa}(5.1 \mathrm{ksi}) \text {, }
$$

where $\mathrm{p}=$ operating pressure $=1.38 \mathrm{MPa}(200 \mathrm{psi})$,

$$
R=\operatorname{radius}=1.3 \mathrm{~m}(4.3 \mathrm{ft} .) \text {, }
$$

and $t=$ thickness $=25.4 \mathrm{~mm}(1.0 \mathrm{in.})$.

The crack length, can be estimated from the length of the black deposit that marked the initiation. The black deposit existed from CC $7.40 \mathrm{~m}$ to CC $8.20 \mathrm{~m}$, and it delineated a part-through crack that was $800 \mathrm{~mm}$ ( $31 \mathrm{in.}$ ) long. The leak occurred because the depth of the crack reduced the remaining ligament of material to the extent that it could no longer support the 
operating pressure of the vessel. Assuming failure at the tensile strength, $\sigma_{\text {ts }}$, of the steel, leakage occurred when the crack depth, $h$, reached the value

$$
h=t\left(1-\frac{\sigma}{\sigma_{t s}}\right)=0.93 t
$$

From examination of the color photographs of the fracture surface, we estimated that this crack depth (0.93t) existed between CC $7.57 \mathrm{~m}$ and CC $7.82 \mathrm{~m}$. When the ligament in this region broke and caused the leak, the length of the through-thickness crack was approximately $250 \mathrm{~mm}$ (10 in.). This crack then propagated through the thin ligament of steel remaining in the area of the initial part-through crack, i.e., the crack attained the length of the black deposit. Thus, the value of crack length used in the fracture mechanics analysis was $800 \mathrm{~mm}$ ( $31 \mathrm{in.)}$.

Substituting $2 \mathrm{a}=800 \mathrm{~mm}(31 \mathrm{in}$.$) and \sigma=35 \mathrm{MPa}(5.1 \mathrm{ksi})$ into equation (4) results in a CTOD value of $0.064 \mathrm{~mm}(0.0025 \mathrm{in}$.). This means that fracture is predicted to occur if the fracture toughness is less than $0.064 \mathrm{~mm}(0.0025 \mathrm{in.})$. However, the fracture toughness results indicated a minimum toughness level of $0.17 \mathrm{~mm}(0.0067 \mathrm{in.})$. Thus, the fracture mechanics analysis predicts that an $800 \mathrm{~mm}$ ( 31 in.) long crack along the weld in the pressure vessel would be stable, i.e., it would leak but not fracture.

But, of course, the pressure vessel failed. Uncertainties in the analysis assumptions for stress and flaw size cannot account for the 2.6-fold difference between the calculated driving force for fracture (applied CTOD $=0.064 \mathrm{~mm}, 0.0025 \mathrm{in.}$ ) and the measured fracture toughness (critical CTOD $=0.17 \mathrm{~mm}, 0.0067 \mathrm{in.}$.).

\section{Fracture Toughness Tests in an $\mathrm{MEA} / \mathrm{H}_{2}$ S Solution}

One of the main differences between the fracture toughness tests and the pressure vessel failure was the different environment. The tests were conducted in air at $38^{\circ} \mathrm{C}\left(100^{\circ} \mathrm{F}\right)$, but the vessel contained a mixture of hydrocarbons, $\mathrm{MEA}$, and $\mathrm{H}_{2} \mathrm{~S}$. The environment in the vessel may have reduced the fracture toughness of the steel. To assess this possibility, two fracture toughness tests were conducted in an $\mathrm{MEA} / \mathrm{H}_{2} \mathrm{~S}$ solution. 
The tests were conducted on specimens from weld $2 / 3$ with the notch in HAZ 2. The solution was a $20 \%$ solution of MEA (commercial grade) in water with a 0.5 molar concentration of $\mathrm{H}_{2} \mathrm{~S}$. A precracked SENB specimen (Figure 9) was installed in a test machine equipped with a box for holding the $\mathrm{MEA} / \mathrm{H}_{2} \mathrm{~S}$ solution. The solution was poured into the box until the specimen was completely immersed. The solution was heated by water flowing through a copper coil in the bottom of the box. The temperature was controlled at $38^{\circ} \pm 1^{\circ} \mathrm{C}\left(100^{\circ} \mathrm{F}\right)$ for $10 \mathrm{~min}$. prior to immersing the specimen. Testing was started approximately one hour after immersion of the specimen.

The fracture toughness testing procedure was the same as that used for the tests in air, except that the loading rate was lower. The test sequence was to load the specimen over a period of about $15 \mathrm{~min}$. at a constant displacement rate of $6 \times 10^{-4} \mathrm{~mm} / \mathrm{s}\left(2.4 \times 10^{-5} \mathrm{in.} / \mathrm{s}\right)$ from zero to the stress intensity ( $40 \mathrm{MPa} \sqrt{\mathrm{m}}, 36 \mathrm{ksi} \sqrt{\mathrm{in}}$.) calculated for an $800 \mathrm{~mm}$ ( $31 \mathrm{in.}$ ) long crack. This load value was held for about one hour, and then the loading was resumed at the initial displacement rate and continued past maximum load.

The fracture toughness results in the $\mathrm{MEA} / \mathrm{H}_{2} \mathrm{~S}$ solution are summarized in Table $x$. The CTOD values of $0.19 \mathrm{~mm}$ ( $0.0075 \mathrm{in.})$ and $0.24 \mathrm{~mm}$ (0.0094 in.) and the corresponding load-displacement records were essentially the same as those for minimum-toughness specimens tested in air at $38^{\circ} \mathrm{C}\left(100^{\circ} \mathrm{F}\right)$. There was no apparent crack extension during the hold time; i.e., the loaddisplacement records did not show any incremental displacement at the constant load. Thus, in these tests, the $\mathrm{MEA} / \mathrm{H}_{2} \mathrm{~S}$ environment had no significant effect on fracture toughness.

\section{Fracture Toughness Tests on Hydrogen-Charged Specimens}

Another significant difference between the conditions of the fracture toughness tests and those of the pressure vessel failure was the condition of the material. In the case of the pressure vessel, the steel was charged with hydrogen during the several months of service following the spring 1984 inspection. Hydrogen was known to enter the pressure vessel steel because of the hydrogen-pressure cracks observed in this investigation. In contrast, the steel used for the fracture toughness specimens probably had a low hydrogen content, because the hydrogen was able to diffuse out of the steel. 


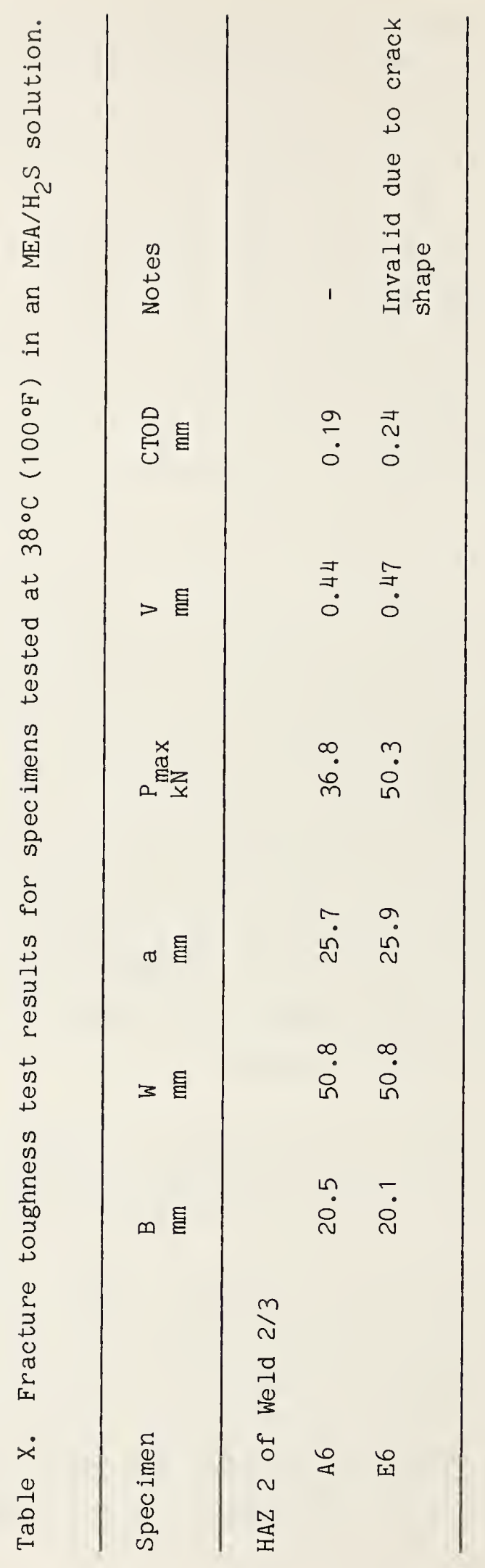


Thus, a series of fracture toughness tests was conducted on specimens that had been charged with hydrogen to determine whether hydrogen lowered the fracture toughness of the steel.

The specimens were machined and the notches were compressed to ensure straight fatigue cracks, and then the specimens were precracked by fatigue. The specimens were immersed in the NACE solution (salt water and acetic acid at $\mathrm{pH}=3$ ) at room temperature for periods of 96 to $120 \mathrm{~h}$. During the final hours of exposure, the temperature of the NACE solution was raised to $38^{\circ} \mathrm{C}$ $\left(100^{\circ} \mathrm{F}\right)$. Each specimen was removed from the solution, installed in the test machine within $3 \mathrm{~min}$. and loaded immediately at a constant displacement rate, $6 \times 10^{-4} \mathrm{~mm} / \mathrm{s}\left(2.4 \times 10^{-5} \mathrm{in.} / \mathrm{s}\right)$ for SENB specimens and $4 \times 10^{-4} \mathrm{~mm} / \mathrm{s}$ $\left(1.6 \times 10^{-5} \mathrm{in./s}\right)$ for compact specimens. During loading, typically one hour to failure, the specimen was enclosed in a box in which that the temperature was controlled to $38 \pm 1^{\circ} \mathrm{C}\left(100^{\circ} \mathrm{F}\right)$.

Two types of tests were conducted on separate groups. The first group consisted of three SENB specimens taken from Ring 3 and notched near HAZ 2 (1 specimen) or HAZ 3 (2 specimens). These were tested in accordance with the procedures of BS 5762 [6]. The CTOD values measured were $0.096 \mathrm{~mm}$ $(0.0038$ in.) in HAZ 2 and $0.070 \mathrm{~mm}(0.0028$ in.) and $0.064 \mathrm{~mm}(0.0025$ in.) in HAZ 3. The HAZ 3 values are similar to the calculated driving force of $0.064 \mathrm{~mm}(0.0025 \mathrm{in.})$, and thus provide a reasonable explanation for the fracture. Thus, it was decided to conduct additional tests on specimens notched in HAZ 1 of Weld 1/2, the location where the vessel failed.

The HAZ 1 specimens were taken from Ring 1 between $\mathrm{CC} 1.62 \mathrm{~m}$ and CC $2.29 \mathrm{~m}$. This piece was cut from the portion of Ring 1 where the fracture propagated through Course 2, away from Weld 1/2. The fracture toughness specimens were compact specimens of the $1 \mathrm{~T}$ configuration (width $=50.8 \mathrm{~mm}$, $2.00 \mathrm{in}$. and height $=61 \mathrm{~mm}, 2.40 \mathrm{in}$ ). The CTOD at maximum load was calculated using the analysis method given in the Draft ASTM Test Method for Crack Tip Opening Displacement (CTOD) Testing:

$$
\delta=\frac{K^{2}\left(1-v^{2}\right)}{2 \sigma_{y s} E}+\frac{r_{p}\left(w-a_{0}\right) v_{p}}{r_{p}\left(w-a_{0}\right)+a_{0}}
$$


where $r_{p}=0.4=$ rotation factor,

$\mathrm{W}^{\mathrm{p}}=$ specimen width,

$a_{0}=$ initial crack length,

$\mathrm{V}_{\mathrm{p}}=$ plastic part of load line displacement,

$\nu=$ Poisson's ratio,

and

$\sigma_{\mathrm{ys}}=0.2 \%$ offset yield strength,

$$
K=Y P / B \sqrt{W} \text {, }
$$

where $P$ = load,

$B=$ specimen thickness,

and $Y=$ stress intensity factor coefficient;

$$
\begin{aligned}
Y= & (2+a / W)\left[0.886+4.64 a / W-13.32(a / W)^{2}\right. \\
& \left.+14.72(a / W)^{3}-5.6(a / W)^{4}\right] /(1-a / W)^{3 / 2},
\end{aligned}
$$

where $\mathrm{a}=$ crack length.

The CTOD values measured in $\mathrm{HAZ} 1$ at $38^{\circ} \mathrm{C}\left(100^{\circ} \mathrm{F}\right)$ were $0.071(0.0028$ in.) and $0.081 \mathrm{~mm}(0.0032 \mathrm{in.})$. These values were similar to those measured in HAZ 3 with SENB specimens and only slightly higher than the calculated driving force of $0.064 \mathrm{~mm}(0.0025 \mathrm{in.})$. The results are summarized in Table XI.

In addition to measuring CTOD in the compact specimens, crack extension was measured as a function of load using the unloading compliance method of ASTM E 813 [16]. The results are presented in the form of CTOD versus crack extension $(\Delta a)$ curves in Figure 39. From these curves, the CTOD at the initiation of tearing was found to be $0.032 \mathrm{~mm}(0.0013 \mathrm{in}$.) by the procedures of the Draft ASTM Test Method for CTOD Testing (November 1985). This extremely low value of CTOD indicates low tearing resistance and means that cracks that are shorter than the critical size can grow at the stress levels that occur in the pressure vessel. 


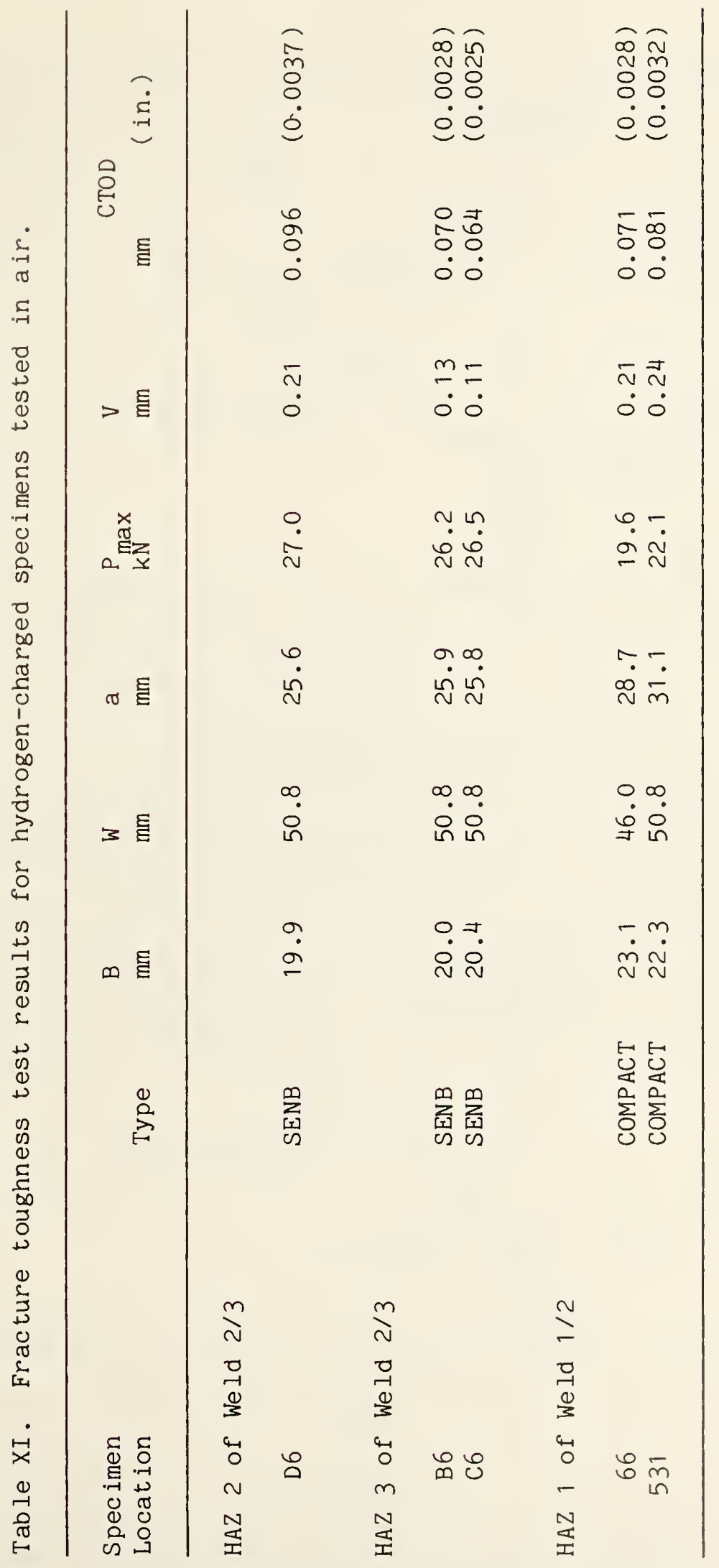




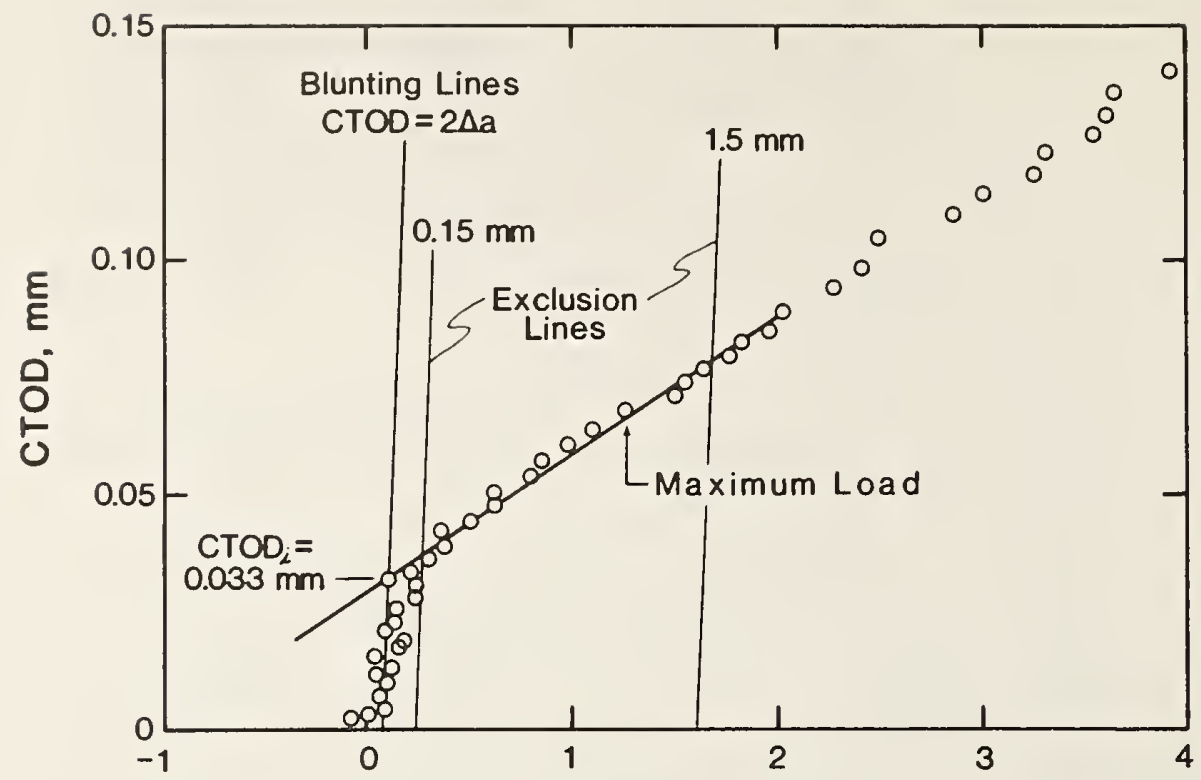

$\Delta \mathrm{a}, \mathrm{mm}$

a. Specimen 66

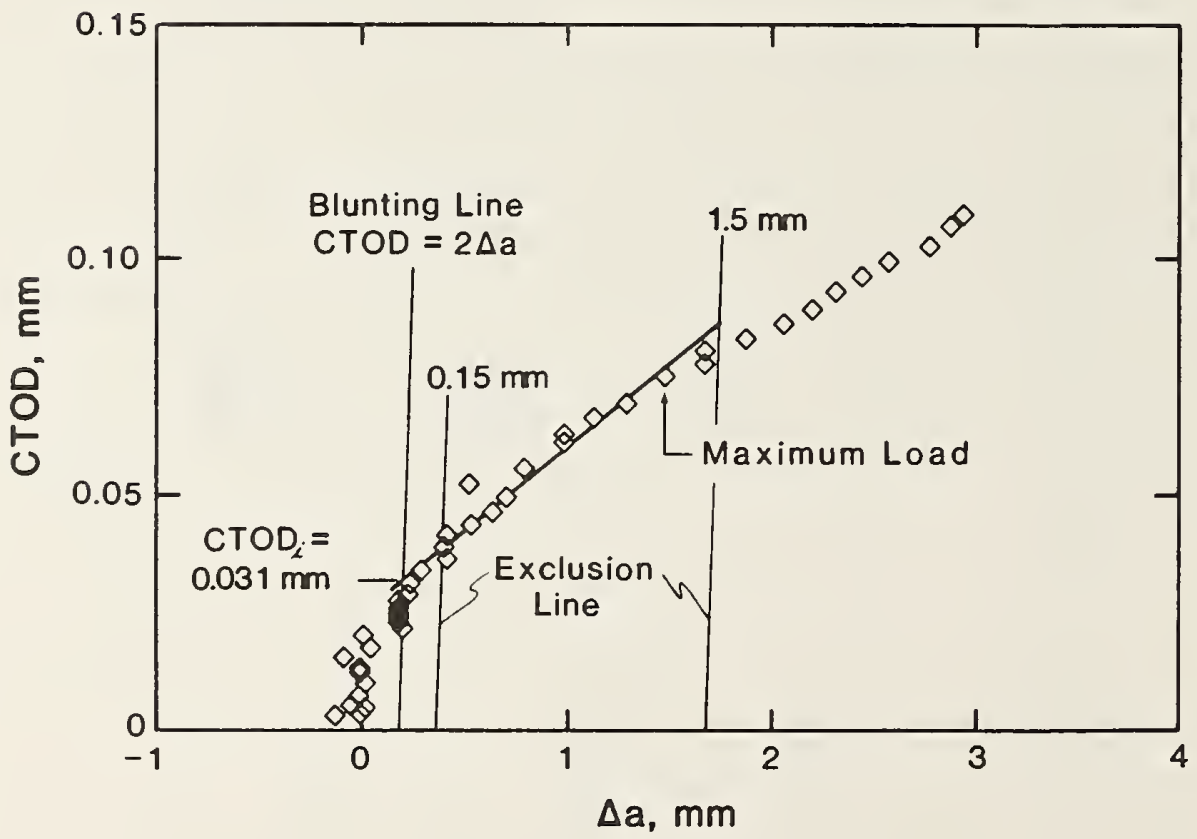

b. Specimen 531

Figure 39. CTOD vs. crack extension, $\Delta a$, curves for the Course 1 side of Weld $1 / 2$ after hydrogen charging. Tested at $38^{\circ} \mathrm{C}\left(100^{\circ} \mathrm{F}\right)$.

Fracture analysis was conducted using the CTOD value at maximum load. 
A fracture mechanics analysis based on the CTOD criterion was conducted by using best estimates of the stress, crack size, and material properties for the vessel at the time of rupture. The axial stress was computed to be $35 \mathrm{MPa}(5.1 \mathrm{ksi})$ for the normal operating pressure and the nominal vessel dimensions. The crack length was measured to be $800 \mathrm{~mm}$, the length of the black deposit on the fracture surface in the vicinity of the leak. A through-thickness crack was assumed because ligament tearing, resulting in the leak, occurred prior to final rupture. The fracture toughness values used were measured in the CTOD tests. The results of the fracture mechanics assessment were:

1. The CTOD value at rupture was calculated to be $0.064 \mathrm{~mm}$, but the minimum critical CTOD measured in the first series of fracture toughness tests was $0.17 \mathrm{~mm}(0.0067 \mathrm{in.})$. Thus, this analysis indicates that the vessel should not have ruptured.

2. The critical CTOD measured after hydrogen charging ranged from 0.064 to $0.096 \mathrm{~mm}(0.0025$ to $0.0038 \mathrm{in}$.). The drop in toughness was attributed to hydrogen embrittlement.

3. Using the toughness values for hydrogen-embittled steel, the calculated CTOD for the vessel is similar to the measured CTOD for the material. Thus, fracture would be expected to occur under the conditions estimated to exist in pressure vessel 12D701. 

1. The pressure vessel fractured along a circumferential path adjacent to a repair weld made on site when a section of the vessel was replaced.

2. The steel plates and welds used for initial construction and for replacement of the vessel section met the specified requirements for chemical composition and mechanical properties.

3. The repair welding procedure used for the circumferential welds caused a hard, crack-susceptible microstructure to form in the heat-affected zone. Near the vessel surface, this microstructure was not tempered by subsequent weld passes. Similar microstructures were not found near the vertical repair welds or the original construction welds because lower cooling rates are associated with their respective welding procedures.

4. Cracks developed during operation of the vessel at the inside surface in the hard, crack-susceptible microstructure adjacent to the circumferential repair welds. Their probable cause was hydrogen stress cracking.

5. These surface cracks propagated in a zigzag path through the vessel wall. Their probable cause was hydrogen pressure cracking.

6. When the deepest of the pre-existing cracks extended through more than ninety percent of the wall thickness, the remaining ligament of steel tore, causing a leak. The ligament continued to tear until the length of the through crack was approximately $800 \mathrm{~mm}$ (31 in.).

7. Catastrophic rupture occurred at an axial stress level estimated to be $35 \mathrm{MPa}(5.1 \mathrm{ksi})$, which is less than ten percent of the strength of the steel. The fracture occurred at such a low stress level because the vessel was weakened by:

- The $800 \mathrm{~mm}$ long pre-existing crack that initiated the fracture and other pre-existing cracks around the circumference along the path of the fracture.

- Hydrogen embittlement of the steel that reduced the fracture resistance of the steel by more than half. 
8. The source of the hydrogen that caused the pre-existing cracks and the embrittlement of the steel was the hydrogen sulfide in the process stream. 
1. Failure Analysis and Code Compliance Review of the Monoethanolamine Absorber Vessel 12D701 at the Union Oil Refinery, Lemont, Illinois, Packer Engineering Associates, Inc., Naperville, Illinois, submitted to the Illinois Office of the State Fire Marshal, Springfield, Illinois 1985.

2. Boiler and Pressure Vessel Code, Section VIII, Pressure Vessels, American Society of Mechanical Engineers (ASME), New York, New York, 1968.

3. Method for Optical Emission Vacuum Spectrometric Analysis of Carbon and Low-Alloy Steel, ASTM E 415, American Society for Testing and Materials, Philadelphia, Pennsylvania, 1985.

4. Methods of Tension Testing Metallic Materials, ASTM E 8, American Society for Testing and Materials, Philadelphia, Pennsylvania, 1985.

5. Methods for Notched Bar Impact Testing of Metallic Materials, ASTM E 23, American Society for Testing and Materials, Philadelphia, Pennsy lvania, 1985.

6. Methods for Crack Opening Displacement (COD) Testing, BS 5762, British Standards Institution, London, 1979.

7. Test Method for Evaluation of Pipeline Steels for Resistance to Stepwise Cracking, NACE Standard TM-02-84, National Association of Corrosion Engineers, Houston, Texas, 1984.

8. Method for $y$-Groove Cracking Test, Japanese Industrial Standard, JIS Z 3158, Japan Welding Engineering Society, Tokyo.

9. Specification for Substitute Ocean Water, ASTM D 1141, American Society for Testing and Materials, Philadelphia, Pennsylvania, 1980.

10. Test Method for Testing of Metals for Resistance to Sulfide Stress Cracking at Ambient Temperatures, NACE Standard TM-01-77, National Association of Corrosion Engineers, Houston, Texas 1977.

11. Novak, S. R. and Rolfe, S. T., Modified WOL Specimen for $\mathrm{K}_{\text {Iscc }}$ Environmental Testing, Journal of Materials, 4(3), 1969, pp. 701-728.

12. Standard Test Method for Plane-Strain Fracture Toughness of Metallic Materials, ASTM E 399, American Society for Testing and Materials, Philadelphia, Pennsylvania, 1983.

13. Semiquantitative Spectrographic Analysis of Miscellaneous Materials by the Graphite Dilution Technique, ASTM E 02 SM11-22, in Methods for Emission Spectrochemical Analysis, American Society for Testing and Materials, Philadelphia, Pennsylvania, 1982. 
14. McClintock, F. A. and Irwin, G. R., "Plasticity Aspects of Fracture Mechanics, in ASTM STP 381, American Society for Testing and Materials, Philadelphia, Pennsy lvania, 1965, pp. 84-113.

15. Rooke, D. P. and Cartwright, D. J., Compendium of Stress Intensity Factors, Her Majesty's Stationery Office, London, 1974, pp. 327-329.

16. Test Method for $\mathrm{J}_{\mathrm{Ic}}$, A Measure of Fracture Toughness, ASTM E 813 , American Society for Testing and Materials, Philadelphia, Pennsy lvan ia, 1985. 


APPENDIX A - FIELD INVESTIGATION

December 1984

Prepared by: Bruce W. Christ

Fracture and Deformation Division

Institute for Materials Science

and Engineering

National Bureau of Standards

Boulder, Colorado 80303

Robert Shull

Metallurgy Division

Institute for Materials Science

and Engineeering

National Bureau of Standards

Gaithersburg, Maryland 20899 

ABSTRACT

At the July 30, 1984 invitation of the Regional Administrator of the Occupational Safety and Health Administration in Chicago, Illinois, the National Bureau of Standards conducted a field investigation of a July 23, 1984 incident at the Union Oil Company Refinery located at Lemont, Illinois. Drs. Bruce Christ and Robert Shull visited the incident site with OSHA Compliance officers between July 30 and August 3, 1984.

A 16-year old, $16.8 \mathrm{~mm}$ (55-ft) tall amine absorber tower, constructed in 1968 and designated pressure vessel 12D701, had ruptured into two pieces and caused fires which led to extensive damage at the south end of the refinery. Custody of the ruptured pressure vessel was in the hands of state Fire Marshal's office.

The NBS field investigation focused on visual examination and photography of both the site and the two major pieces of the ruptured pressure vessel and on participation in witness interviews conducted by OSHA Compliance Officers from the Calumet City, Illinois Area Office.

An eye witness reported that the rupture of pressure vessel 12D701 originated at a leak. Longitudinal tensile stress from internal pressure caused the through-wall defect at the leak to grow circumferentially and eventually to separate the vessel into two major pieces. The circumferential fracture path followed a zone of low fracture resistance in the vicinity of the girth weld joining Shell Course 1 and replacement Shell Course 2. The through-wall defect at the leak developed sometime between May 1974, when the replacement shell course was welded into place, and July 23, 1984 when the leak was reported.

Pressure vessel 12D701 sustained substantial corrosion cracking (blister cracking) on the inside walls in the vicinity of the inlet piping near the bottom of the vessel. The delamination via corrosion was a continuing process during the life of the vessel; it was so severe as to require replacement of the original Shell Course 2 in 1974 after six years of service, protection of Shell Course 1 and the bottom head with a Monel interior liner in 1976, and weld repair of the corroded liner in April 1984.

Numerous refinery records and much technical data and analysis on test specimens taken from the pressure vessel are needed to facilitate an impartial assessment of the causes of the catastrophic fracture of pressure vessel $12 \mathrm{D} 701$. 



\section{APPENDIX A - FIELD INVESTIGATION}

\section{CONTENTS}

\subsection{General Information}

\subsection{Reference}

1.2 Background

1.2.1 Sources of Information about the Incident

1.2.2 Description of Incident

1.2.3 Recovering Components of Pressure Vessel 12D701

1.2.4 Function of Pressure Vessel 12D701 in the Refinery Process

1.2.5 Custody of the Components of Pressure Vessel 12D701

1.2.6 Preliminary NBS Reports to OSHA/U.S. Department of Labor

2.0 Description of Pressure Vessel 12D701

2.1 Sources of Information

2.2 Construction

2.3 Shells and Heads

2.3.1 Materials, Dimensions, and Fabrication

2.3.2 Calculation of Minimum Wall Thickness

2.3.3 Corrosion Allowance on Thickness

2.3.3.1 General Requirements for Corrosion Allowance

2.3.3.2 Corrosion Allowances for Pressure Vesse 1 12D701

2.4 Valves

3.0 Inspection and Maintenance History

3.1 Documents Available During the Field Investigation

3.2 Replacement of Shell Course 2

3.3 Inlet Piping Penetration of Girth Welds

3.4 Installation of Internal Metal Liner

4.0 Description and Assessment of Fracture from Visual Observations

4.1 Initiation of Fracture

4.2 Characteristics of the Fracture

4.2.1 Orientation and Location of Fracture Path

4.2.2 Appearance of Fracture Surfaces to Unaided Eye

4.3 Videotapes of Fracture Surfaces

4.4 Implications of the Fracture Characteristics 
5.0 Discussion

5.1 Probable Cause of the Refinery Incident

5.2 Through-Wall Defect in Pressure Vessel 12D701

5.3 Circumferential Separation in the Vicinity of a Girth Weld

5.4 Corrosion of Pressure Vessel 12D701

5.4.1 Corrosion Caused by Hydrogen Sulfide

5.4.2 Galvanic Corrosion

5.5 Information Needed for Assessment of Fracture

6.0 Conclusions

7.0 References 


\subsection{REFERENCE}

U.S. Department of Labor, Occupational Safety and Health Administration, Regional Office, Chicago, Illinois. This field investigation was conducted at the request of Mr. Frank L. Strasheim, Regional Administrator, in memoranda dated July 30, 1984, to Dr. R. P. Reed, Chief of the NBS Fracture and Deformation Division, Boulder, Colorado, and to Dr. L. Testardi, Chief of the NBS Metallurgy Division, Gaithersburg, Maryland. The request memoranda followed telephone calls from Mr. Kenneth Yotz, Assistant Regional Administrator for Technical Support in the OSHA Chicago Regional Office, to Dr. Robert Shull of the NBS Metallurgy Division on July 26, 1984 and to Dr. Bruce Christ of the NBS Fracture and Deformation Division on July 27 and 29, 1984. OSHA Cost Coding Number 4400-E-2-F-501-22000-2112-000 supported this work.

\subsection{BACKGROUND}

\subsubsection{Sources of Information about the Incident}

Information about the incident described below was obtained principally from: staff of the OSHA Regional Office in Chicago; staff of the OSHA Area Office in Calumet City, Illinois; employees of the Union Oil Company petroleum refinery at Lemont, Illinois; and the Herald News of Joliet, Illinois, the July 29, 1984 edition.

OSHA Regional Office staff members who provided information include: Mr. Frank L. Strasheim, Mr. William Murphy (temporary assignment), Mr. Kenneth Yotz, and Mr. James Sumpter. Some discussions were also held with Mr. Richard Fiore, an attorney representing the OSHA Regional Office.

OSHA Area Office staff members who provided information include Mr. William Funcheon (Office Director) and the following Compliance officers: Mr. James Whyte, Mr. Joseph Howicz, Mr. Michael Ypsilanti, Mr. Gregg Mitchell, and Mr. Young Paul Li. Copies of refinery documents pertaining to construction, inspection maintenance, and repair were received from Mr. Funcheon via mail on August 7, 1984 at NBS in Boulder, Colorado. 
Refinery employees who provided information include Mr. Ronald Runge (Chief of Plant Operations), Mr. Daniel Sobieski (Chief Laison Staff. Person), Mr. Denton, Mr. Bassett, Mr. H. Kolff van Oosterwijk, Mr. E. Schaschl, and Mr. Emil Bereczky.

The July 29, 1984 Herald News of Joliet, Illinois carried a timetable of events purporting to list occurrences during the first 24 hours of the incident at the refinery .

In addition, some information was obtained from an alleged eyewitness, who claimed to be on a hill about one mile east of the refinery in the beginning moments of the incident.

This information was provided to Drs. Bruce $W$. Christ and Robert Shull, who visited the site of the incident during the week of July 30, 1984. Both are technical experts in the fields of materials science and engineering. Dr. Christ arrived at the site around 4:30 p.m. on Monday July 30, 1984 . Dr. Shull arrived at the site around 8:30 a.m. on July 31, 1984. Drs. Christ and Shull were accompanied and guided by OSHA staff members from the Area Office in Calumet City, Illinois at all times while at the site. All information from refinery employees was transmitted through, or in the presence of, OSHA staff members.

At $\mathrm{Dr}$. Christ's request, OSHA arranged to have two professional photographers at the site during the week of the field investigation. The photographers obtained several videotapes of important aspects of the incident and provided the tapes to the OSHA Area Office in Calumet City.

Drs. Christ and Shull assisted the OSHA Compliance Officers via technical interpretation of observations at the incident site and technical assistance during interviews by Compliance officers taking witness statements. Drs. Christ and Shull left the site at 3:15 pm on Friday, August 3, 1984. Drs. Christ and Shull provided technical assistance to various OSHA staff members via telephone conversations initiated by OSHA in the weeks following their visit to the site.

\subsubsection{Description of Incident}

A refinery worker observed a leak in an upright, $2.6 \mathrm{~m}$ ( $8.5 \mathrm{ft}$.) diameter, cylindrical pressure vessel which was about $19.4 \mathrm{~m}$ (63.5 ft.) high (from 
the base ring to the top). The vessel, designated 12D701, was an amine absorber tower located in the unsaturated gas plant at the south end of the refinery. This pressure vessel nominally operated at $1.4 \mathrm{MPa}$ (200 psig) and $38^{\circ} \mathrm{C}\left(100^{\circ} \mathrm{F}\right)$, and nominally contained about $45 \mathrm{kl}(12,000 \mathrm{gal}$.$) of liquid$ propane $\left(C_{3}\right)$, liquid butane $\left(C_{4}\right)$, and aqueous amine solution (MEA). The purpose of this amine absorber tower in the refinery process was to remove hydrogen sulfide from the hydrocarbon process stream.

The refinery worker, who observed the leak, notified a plant supervisor close to the pressure vessel at about 5:38 p.m. on Monday, July 23, 1984. The supervisor immediately came to the scene and observed the leak in pressure vessel 12D701. The supervisor attempted to mitigate the leak by climbing a $4.6 \mathrm{~m}$ (15 ft.) ladder attached to pressure vessel 12D701 and manipulating a valve. Forceful jetting of vapor leaking from the pressure vessel near the valve forced the supervisor to abandon the effort to manipulate the valve. While retreating from the leaking pressure vessel, the supervisor observed that the leak was growing larger. The supervisor took cover under some refinery equipment about $21 \mathrm{~m}$ (70 ft.) from the pressure vessel.

Shortly thereafter, a major explosion occurred, which caused ground tremors to be felt about a mile east of the refinery. The time of this explosion was estimated to be $5: 53 \mathrm{p} \cdot \mathrm{m}$. Apparently, this explosion occurred when the pressure vessel completely separated circumferentially into two major pieces. The upper portion of the pressure vessel, approximately $12 \mathrm{~m}$ (40 ft.) long was launched into the air. The lower portion of the pressure vessel remained standing almost upright on its base ring. A white cloud formed at ground level near the ruptured pressure vessel; then a fire started. Black smoke began to fill the air. This smoke obscured the flight path of the launched portion of the ruptured pressure vessel; a second major explosion occurred at about $6: 20 \mathrm{p} . \mathrm{m}$. Firefighters were arriving at the scene by this time. Fires were brought under control by mianight. The explosions and fires created several acres of charred wreckage and debris.

It was the consensus of refinery employees that the rupture of pressure vesse 1 12D701 was the initial event that led to the fires and extensive damage at the south end of the refinery. 


\subsubsection{Recovering Components of Pressure Vessel 12D701}

Upper Portion. The upper $12 \mathrm{~m}$ (40 ft.) of pressure vessel 12D701 was found about $915 \mathrm{~m}$ (3000 ft.) from its original location in the refinery. It had been propelled in a southeasterly direction to a field outside the refinery. By chance, it landed on an electric power line transmission tower. The landing impact collapsed the tower and made a crater about $3.7 \mathrm{~m} \mathrm{(12} \mathrm{ft.)} \mathrm{deep}$ and perhaps $6 \mathrm{~m}$ (20 ft.) in diameter.

The weight of this section of pressure vessel 12D701 was estimated to be roughly $29 \mathrm{Mg}[(40 \mathrm{ft} . / 55 \mathrm{ft}).(78,807 \mathrm{lb})=57,.529 \mathrm{lb} .=28.8 \mathrm{~T}]$. At the time of separation, pressure vessel 12D701 was thought to be practically full of liquid; a rough estimate indicates that the amount of liquid in the upper portion was approximately $33 \mathrm{kl}[(40 \mathrm{ft} .155 \mathrm{ft}).(12,000 \mathrm{gal})=.8760 \mathrm{gal}$.

The upper portion, with the associated piping, was loaded onto a flatbed trailer and trucked to a parking lot inside the refinery, where it was examined visually. A safety relief valve remained attached to the top head. The circumferential fracture path closely followed a girth weld which joined two shell courses of pressure vessel 12D701.

The upper portion was flattened along most of its $12 \mathrm{~m}$ ( $40 \mathrm{ft}$. ) length. The cause of the flattening was not evident during the week of July 30 August 3, 1984. The upper portion showed some crushing of the top head, suggesting that it had landed top down. Soil adhered to various locations on the upper portion, including the outside surface near the head and the inside wall near the fracture surface. The inside of the upper portion at the open end smelled intensely of hydrocarbon vapors during the week of the field inspection.

Lower Portion. The lower $4.6 \mathrm{~m}$ (15 ft.) of pressure vessel 12D701 remained standing in the refinery nearly upright on its base ring. On July 30, 1984, the inlet pipe and distributor were still connected to the lower portion, and the lower portion was about $2 / 3$ full of an unknown liquid with a strong odor. A liner installed inside the lower portion of pressure vessel 12D701 was visible above the liquid. The visible portion appeared to be intact. The top edge of the liner was fastened to the inside wall around the entire circumference. The top edge of the liner appeared to be welded in place 
along a girth weld which joined the lower two shell courses of pressure vessel 120701. The fracture path nearly coincided with the top edge of the liner.

The lower portion of pressure vessel 12D701 was removed from its base on July 31, 1984. It was loaded onto a flatbed trailer, trucked to the parking lot inside the refinery where the trailer carrying the upper portion of pressure vessel 12D701 was standing, and parked alongside this trailer. Construction workers dismantling the lower portion indicated that the J-bolts holding the pressure vessel to its base had been stretched about $6 \mathrm{~mm}(0.25 \mathrm{in.})$. These bolts were not examined further during the week of the field investigation.

1.2.4. Function of Pressure Vessel 12D701 in the Refinery Process

Pressure vessel 12D701 was an amine absorber tower. Its function in the refinery process was to remove hydrogen sulfide from a steam of liquid propane and liquid butane. Normal operating conditions of the pressure vessel were: full of liquid; about $38^{\circ} \mathrm{C}\left(100^{\circ} \mathrm{F}\right)$; about $1.4 \mathrm{MPa}$ (200 psig).

When the pressure vessel was in operation, the process stream containing propane, butane, and hydrogen sulfide entered the vessel at the bottom, rose, and exited at the top. Aqueous amine solution (MEA) entered the vessel at the top, decended, and by contacting the upward-flowing hydrocarbon stream, removed hydrogen sulfide. The aqueous amine solution enriched with hydrogen sulfide collected in the bottom 3 to $4.6 \mathrm{~m}$ (10 to $15 \mathrm{ft}$.) of the pressure vessel and was periodically drawn off.

Information about the operating pressure and temperature of pressure vessel 12D701 just prior to the rupture was not available during the week of the field investigaton, nor was information about the chemical composition of the process stream over a period of time prior to the rupture. Knowledge of the operating pressure and temperature and of the chemical composition of the process stream would be useful in assessing the fracture.

\subsubsection{Custody of Components of Pressure Vessel 12D701}

The State Fire Marshal's office had custody of the components of pressure vessel 12D701 during the week of the field investigaton. Accordingly, the NBS investigative role involved activities that did not disturb the ruptured 
vessel, e.g., visual and photographic observations and some measurements with a hand-held tape. The NBS investigators were not involved in any metal cutting operations.

1.2.6 Preliminary NBS Reports to OSHA/U.S. Department of Labor Two preliminary reports describing the NBS field investigation of the incident were sent from NBS to OSHA, dated August 10, 1984 and August 29 , 1984. A 1 
2.1 SOURCES OF INFORMATION

The information reported in this section was taken principally from engineering drawings ${ }^{2}, A 3$ provided to OSHA Compliance Officers by oil refinery personnel in July 1984. Stress-pressure-wall thickness calculations were based on Section VIII - Division 1 of the ASME Boiler and Pressure vessel Code. A4 Some information in this section came from direct observations made on recovered components of pressure vessel 12D701.

\subsection{CONSTRUCTION}

Pressure vessel 12D701 was constructed in 1968 in accord with the ASME Boiler and Pressure Vessel Code - Specification UW. The as-constructed vessel was a cylindrical shell standing vertically. The vessel itself was about $16.8 \mathrm{~m}$ (55 ft.) high and about $2.6 \mathrm{~m}$ ( $8.5 \mathrm{ft}$. ) in diameter. The vessel was supported on a pedestal about $2.6 \mathrm{~m}$ ( $8.5 \mathrm{ft}$.$) high. Nominal wall thickness$

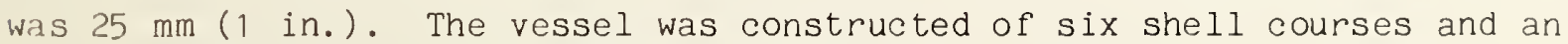
ellipsoidal top and bottom head.

\subsection{SHELLS AND HEADS}

2.3.1 Materials, Dimensions, and Fabrication

ASTM A516 Grade 70 was specified for the six shell courses. Plate dimensions were: $269 \mathrm{~cm} \times 843 \mathrm{~cm} \times 2.5 \mathrm{~cm}(106$ in. $x 332 \mathrm{in.} \times 1$ in.). The cylindrical shells were fabricated by shaping the plate to a cylindrical configuration and joining the edges with longitudinal welds. Table AI summarizes some design and construction data.

The top head was ellipsoidal in shape. ASTM A516 Grade 70 steel plate was the specified material. The top head had an outside diameter of $2.6 \mathrm{~m}$ (104 in.) and a minimum thickness of $21 \mathrm{~mm}(0.814 \mathrm{in.)}$.

The bottom head was ellipsoidal in shape. ASTM A516 Grade 70 was the specified material. The bottom head had an outside diameter of $2.6 \mathrm{~m}$ (104 in.) and a minimum thickness of $22 \mathrm{~mm}$ (0.865 in.). Presumably the extra 
Table A1. Design information for pressure vessel 12D701A3

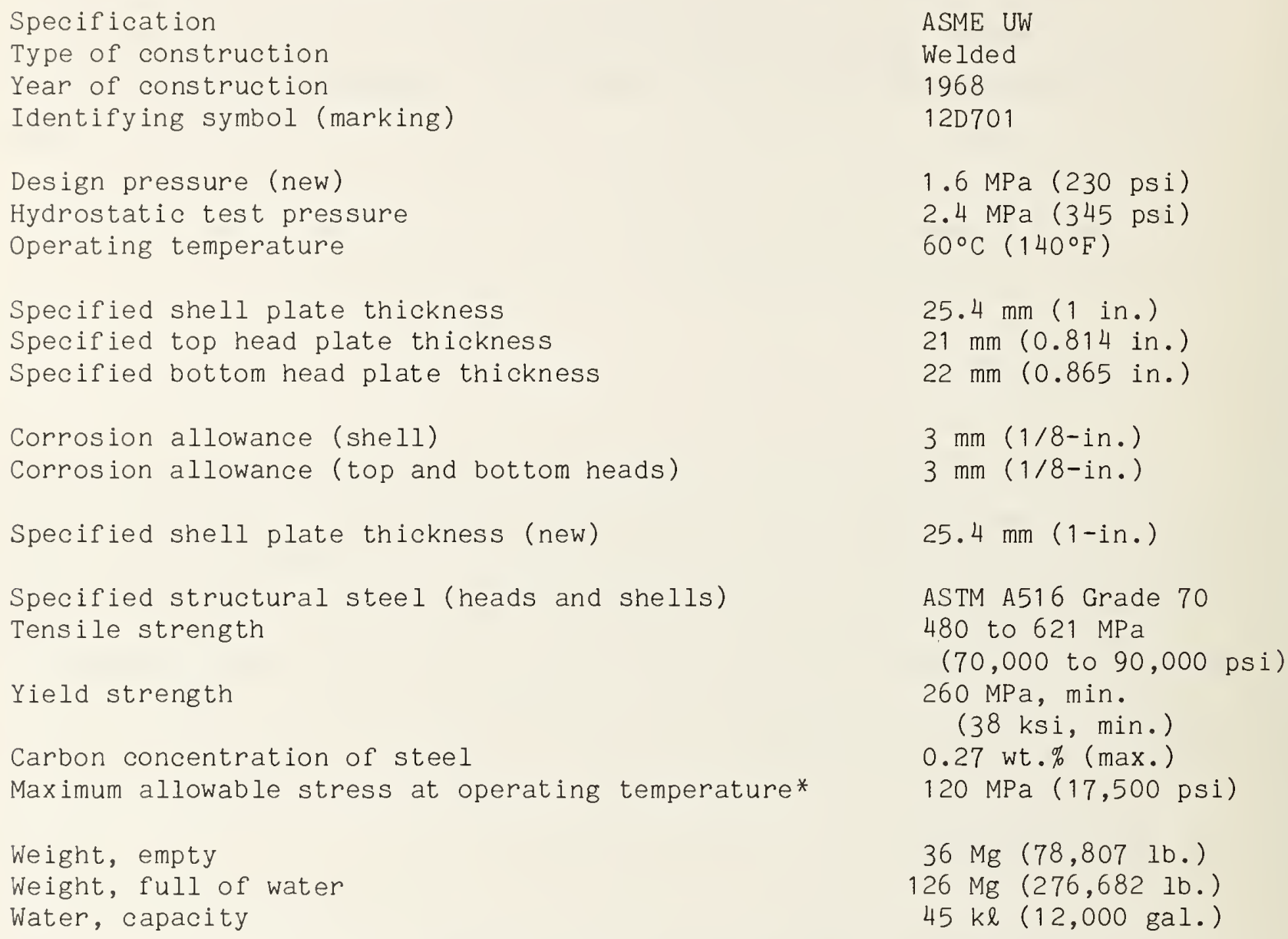

* from Table UCS-23 of ASME Boiler and Pressure Vessel Code 44 
thickness of the bottom head, as compared to that. of the top head, was intended to provide an allowance for corrosion due to the corrosive fluid that concentrated in the bottom of the pressure vessel during normal operation.

The shell courses and heads were joined by girth welds. Documentation about the welding procedures was not available for review during the field investigation.

\subsubsection{Calculation of Minimum Wall Thickness}

Sections UG-27 $4 \mathrm{a}$ and $U G-32^{4 b}$ in the General Requirements part of Section VII of the ASME Boiler and Pressure Vessel Code specify procedures for calculating the minimum wall thickness of components of vessels sustaining internal pressure. Calculations of minimum wall thickness for the shell and heads of pressure vessel 12D701 appear below.

\section{Minimum Thickness of Shell Plates}

$$
t=\frac{P R}{S E-0.6 P}
$$

where $t=$ minimum thickness of shell plates in inches, exclusive of corrosion allowance

$\mathrm{P}=$ design pressure $=1.6 \mathrm{MPa}(230 \mathrm{psi})$

$\mathrm{S}=$ maximum allowable circumferential tensile stress at $60^{\circ} \mathrm{C}\left(140^{\circ} \mathrm{F}\right.$

$=121 \mathrm{MPa}(17,500 \mathrm{psi})$ for ASTM A516 Grade 70 steel (from Table USC-23/Section VIII - ASME B \& PV Code) A $^{4 C}$

$R=$ inside radius of shell (before corrosion allowance is added in)

$=8.4 \mathrm{~m}(332 \mathrm{in.}) /(2 \pi)=1.3 \mathrm{~m}(52.8 \mathrm{in.})$

$E=$ joint efficiency $=1$ for fully radiographed joints

Substituting the above values into Equation 1 gives

$t=18 \mathrm{~mm}=\{(230 \mathrm{psi} \times 52.8 \mathrm{in.}) /[(17,500 \mathrm{psi} \times 1)-0.6(230 \mathrm{psi})]=$ 0.70 in.

Therefore, the minimum thickness of shell plates, exclusive of the corrosion allowance, was $18 \mathrm{~mm}$ ( $0.70 \mathrm{in.)}$. 


$$
\tau=\frac{P D}{2 S E-0.2 P},
$$

where $t=$ minimum thickness of head in inches after forming, exclusive of corrosion allowance

$\mathrm{P}=$ design pressure $=1.6 \mathrm{MPa}(230 \mathrm{psi})$

$D=$ inside diameter of the headskirt or inside length of an ellipsoidal head.

$D=2.6 \mathrm{~m}$ (102.3 in.) for bottom head.

$D=2.6 \mathrm{~m}$ (102.4 in.) for top head.

$\mathrm{S}=$ maximum allowable circumferential tensile stress at $60^{\circ} \mathrm{C}\left(140^{\circ} \mathrm{F}\right)$

$=120 \mathrm{MPa}(17,500 \mathrm{psi}$ ) for ASTM A516 Grade 70 steel (from Table USC 23/Section VIII - ASME B \& PV Code ${ }^{A 4 C}$ ).

$E=$ lowest efficiency of any joint in the head $=1$ for fully radiographed joints.

Substituting the above values into Equation A2 gives

$t=17 \mathrm{~mm}[(230 \mathrm{psi} \times 102.4 \mathrm{in.}) /[(2 \times 17,500 \mathrm{psi} \times 1)-(2 \times 230 \mathrm{psi})]$ $=0.675 \mathrm{in}$.

Therefore, the minimum thickness of heads, exclusive of corrosion allowance, was $17 \mathrm{~mm}$ (0.675 in.)

\subsubsection{Corrosion Allowance on Thickness}

\subsubsection{General Requirements for Corrosion Allowances}

Section UG-25 in the General Requirements part of Section VIII of the ASME Boiler and Pressure Vessel Code ${ }^{A 4 d}$ discusses corrosion allowances. Paragraph (b) states, "Vessels or parts of vessels subject to thinning by corrosion, errosion or mechanical abrasion shall have provisions made for the desired life of the vessel by a suitable increase in thickness of the material over that determine by the design formulas, or by using some other suitable method of protection." Paragraph (2) states, "The user or his 
designated agent shall specify corrosion allowances other than those required by the rules of this Division." Essentially, the code leaves it up to the user or designated agent to decide on the amount of corrosion allowance.

\subsubsection{Corrosion Allowance for Pressure Vessel 12D701}

An engineering drawing for pressure vessel 12D701 indicates that the specified corrosion allowance was $3 \mathrm{~mm}$ (1/8 in.) for shell plates and for heads. A3 Adding this corrosion allowance to the minimum thickness to support internal pressure (calculated in section 2.3.2) gives the specified minimum plate thickness at initial construction. Results appear in Table AII. Comparing these results with the plate thicknessess appearing in the engineering drawing ${ }^{3}$ for shells and heads indicates that the actual plate thickness intended for use in initial construction exceeded the specified minimum plate thicknesses.

\subsection{VALVES}

Documentable information about the valves on pressure vessel 12D701 was not abundant during the field investigation. Presumably the inlet and outlet piping had valves to regulate flow of the process streams, but the valves were not identified during this week. A valve identified by refinery employees as a safety relief valve was attached to the upper portion of pressure vesse 1 12D701 as it lay on the flatbed trailer in the refinery parking lot during the field investigation, but it was not examined at that time. The valve that the plant supervisor at tempted to manipulate while a leak was occurring (see Section 1.2.2.) was not positively identified during the field investigation. It would be useful to identify and locate all the valves which regulated internal pressure in pressure vessel 120701 and ascertain the reliability of their performance. 


\subsection{DOCUMENTS AVAILABLE DURING THE FIELD INVESTIGATION}

The documentation about the inspection and maintenance history of pressure vessel 12D701 dealt principally with observations of inside wall corrosion and wall thickness measurements. Some information about the replacement of Shell Course 2 in 1974 and installation of the metal internal liner in 1976 was also available. A summary of Equipment Inspection Reports ${ }^{A}$ cited highlights of biennial inspections between April 1972 and April 1984.

The inspection records that led to repairs by welding were not available. These repairs were thought to be located in the area where the vessel ruptured and separated. Information about the repairs themselves, thought to have been made a few months prior to the date of the incident, was not available.

\subsection{REPLACEMENT OF SHELL COURSE 2}

The April 1972 and April 1974 Equipment Inspection Reports ${ }^{A 5}$ described severe inside wall corrosion near the bottom of pressure vessel 12D701 in the form of blister cracking. Metallurgical examination in May 1972 of a throughwall sample trepanned from the wall of the vessel near the bottom evaluated the corrosion. A6 The size of the sample and the location from which it was taken were not specified. Wall thickness measurements made on original shell Course 2 in April 1972 with ultrasonic techniques indictated thicknesses ranging from $12 \mathrm{~mm}$ ( $0.46 \mathrm{in.)}$ to somewhat more than $25 \mathrm{~mm}$ ( $1 \mathrm{in.)}$. Inspection records showed that one region had thicknesses ranging from 10 to $16 \mathrm{~mm}$ ( 0.39 to $0.63 \mathrm{in.)}$. These values are well below the minimum thickness for shell plates, $18 \mathrm{~mm}$ ( 0.700 in.) listed in column a of Table AII.

A June 26, 1972 memorandum report ${ }^{A 7}$ summarized the visual observations of corrosion, the metallurgical evaluation of the through-wall sample trepanned from a severely corroded region, and results of wall thickness measurements with ultrasonic techniques. It reiterated a recommendation in the 


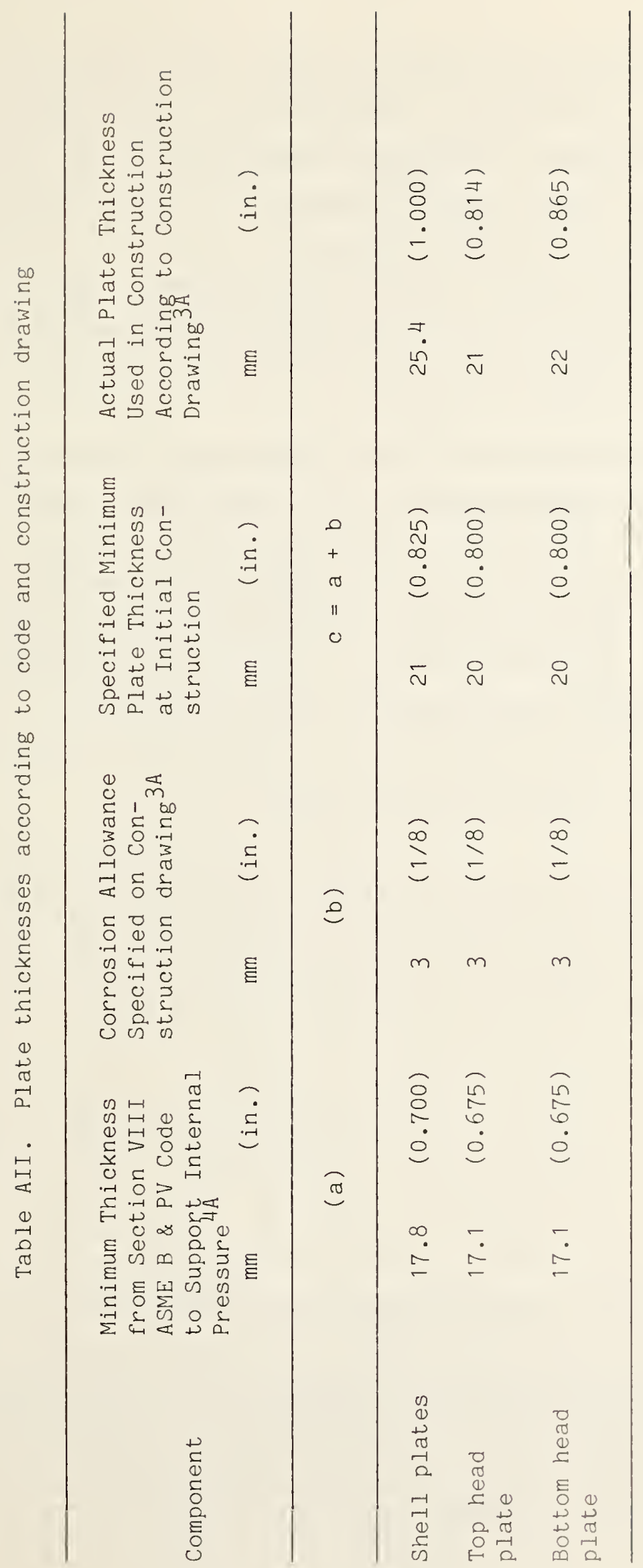


May 1972 Equipment Inspection Report, namely, that the original Shell Course 2 be replaced. The recommended replacement took place between March 28 and May 10, 1974, according to a memorandum dated September 5, 1974. A8 The April 1974 Equipment Inspection Report A5 suggested that one contractor started the replacement and a second one finished it.

Since the fracture path ran through heat-affected zone of Shell course 1 , it would be of interest to know if the heat-affected zone of shell Course 1 from the time of original construction had been removed before replacement Shell Course 2 was welded into place.

The Equipment Inspection Reports ${ }^{A 5}$ between 1976 and early 1984 did not indicate significant deterioration of replacement Shell Course 2. Five gouges on the southeast side of the shell approximately $0.4 \mathrm{~m}$ (16 in.) above the weld seam were reported in April 1978. A5 However, these gouges are not mentioned in subsequent Equipment Inspection Reports. In April 1984, it was reported that all ultrasonic thickness readings taken on the shell of pressure vessel 12D701 were above the nominal thickness.

\subsection{INLET PIPING PENETRATION OF GIRTH WELDS}

The inlet piping for the hydrocarbon process stream penetrated the girth weld joining Shell Course 1 and replacement Shell Course 2. The inlet piping was welded in place. Documentation about the welding procedures used for this penetration were not available for review during the field investigation.

A noteworthy feature of the inlet piping was the distributor at the end, inside the pressure vessel. The distributor was a perforated pipe designed so as to spread the incoming hydrogen-sulfide-rich, liquid hydrocarbon stream throughout the pressure vessel cross section. The position of the distributor inside the pressure vessel was at about the height of the girth weld joining Shell Course 1 and replacement Shell Course 2.

\subsection{INSTALLATion OF INTERnaL METAL LiNER}

The lower portion of pressure vessel 120701 contained an internal metal liner, which had been installed in May 1976. A5 The May 1976 Equipment 
Inspection Report stated that, "The entire surface of shell plate ring 非 had many blisters ranging. in size from 1/4" to 1" diameter." This report also indicated that the liner was installed "to arrest the hydrogen attack." Monel* was the liner material. The specified thickness of the liner was not reported. The May 1976 Equipment Inspection Report establishes that the liner was welded to the inside bottom wall of pressure vessel 12D701 and that the top edge of the liner was welded approximately along the girth weld joining Shell Course 1 and replacement Shell Course 2, as observed on July 30 and 31, 1984 .

Equipment Inspection Reports ${ }^{\mathrm{A} 5}$ indicated that the Monel liner appeared to be in good condition in 1978 and 1980. The liner was not mentioned in a 1982 Equipment Inspection Report. However, a discussion of the liner in a 1984 report ${ }^{A} 5$ indicated that "...eight locations showed signs of seepage of liquids from welds. Lining was heated to drive off trapped liquid and these areas were weld-repaired."

The condition of the liner as it was observed on July 30 and 31, 1984 is described in Section 1.2.3, "Lower Portion," of this report.

*Monel is a nickel-copper alloy containing about $66.5 \%$ nickel, 30\% copper, $1 \%$ manganese, $1 \%$ iron, and about 0.2 to $0.5 \%$ silicon and carbon, balance residuals. Three types of Monel (400, R-405, K-500) are listed on page 68 of the 1984 Materials Processing Data Book published by the American Society for Metals, Metals Park, Ohio. It would be of interest to learn how widespread is the practice of installing protection liners of Monel in the petrochemical industry. 


\subsection{INITIATION OF FRACTURE}

According to an eyewitness account, the fracture originated at a leak that forcefully jetted hydrocarbons from pressure vessel 12D701 (see Section 1.2.2). The observation of a single leak indicated the existence of a single through-wall defect and suggests a single-fracture origin. The area of the leak apparently had undergone repair work by welding some months prior to detection of the leak. Documentation about such repair work was not available during the field inspection.

The same eyewitness account indicated that the initial leak grew larger while it was being observed. This observation suggests propagation of a through-wall defect, indicating that the defect was unstable under the operating conditions of the pressure vessel. (Information about these operating conditions was not available during the field inspection.) In fracture mechanics terminology, the observation of defect growth indicates that the through-wall defect causing the leak exceeded the critical defect size for the local conditions of fracture toughness and applied stress.

\subsection{CHARACTERISTICS OF THE FRACTURE}

4.2.1. Orientation and Location of Fracture Path

a. The fracture path was circumferential.

b. The fracture path followed closely the girth weld and associated heat-affected zone between shell Course 1 and replacement Shell Course 2. Much of the fracture path was in the heat-affected zone rather than in the weld metal.

c. At only one location did the fracture path run through parent metal. This occurred in the northwest quadrant of the vessel's circumference at a distance of about $1.5 \mathrm{~m}$ (61 in.) from the inlet pipe penetration. The total length of the fracture path in parent metal was about $76 \mathrm{~cm}$ (30 in.). 
d. The fracture path nearly coincided with the top circumferential edge of the internal metal liner, which was welded to the inside wall of pressure vessel 12D701 approximately along the girth weld between Shell Course 1 and replacement Shell Course 2.

e. The fracture path was in the immediate vicinity of the in let pipe and distributor, which introduced and distributed a hydrogensulfide-rich hydrocarbon stream into the vessel (see Section 3.3). Moreover, the fracture path was in the vicinity of the highest level of the hydrogen-sulfide-rich aqueous amine solution: which collected in the bottom of the vessel (see Section 1.2.4).

\subsubsection{Appearance of Fracture Surfaces to Unaided Eye.}

a. Fracture surfaces on the upper and lower portions of pressure vessel 12D701 were severely corroded. Soil adhered to several locations on the fracture surface on the upper portion of the vessel.

b. The fracture generally had the appearance of rather low ductility, as evidenced by the rather flat fracture surfaces around the entire circumference.

c. The fracture separated some welded joints associated with the in let piping penetration (see Section 3.3).

d. A possible fracture origin site* was noted in the southwest quadrant of the vessel's circumference, approximately $1.3 \mathrm{~m}$ (53 in.) from the inlet piping penetration. The noteworthy feature on the fracture surface at this location was a through-wall flat spot about 76 to $130 \mathrm{~mm}$ ( 3 to 5 in.) long.

\footnotetext{
*This possible fracture origin was in the vicinity of what appeared to be a series of ladder lugs welded to the outside wall of pressure vessel 12D701. See Section 1.2 .2 for a description of the leak by an eyewitness.
} 


\subsection{VIDEOTAPES OF FRACTURE SURFACES}

Videotapes were made of both fracture surfaces while the upper and lower portions of pressure vessel 12D701 were lying on their sides on the flatbed trailer in the refinery parking lot on August 1 and 2, 1984 (see Section 1.2.3). The tapes were provided to the OSHA Area Office in Calumet City, Illino is.

4.4 IMPLICATIONS OF THE FRACTURE CHARACTERISTICS

Pressure vessel 12D701 ruptured into two major pieces, with the separation occurring along a circumferential fracture path that roughly followed the girth weld joining Shell Course 1 and replacement Shell Course 2. A circumferential fracture path in an internally pressurized cylindrical shell is an unexpected occurrence. It demonstrates that rupture occurred in response to longitudinal stress, not circumferential (hoop) stress, which is twice as large for a given internal pressure.

The maximum design longitudinal stress, approximately $60 \mathrm{MPa}(8,750 \mathrm{psi})$ for the ASTM A516 Grade 70 steel specified for pressure vesse 1 12D701, * is well below the specified ultimate tensile strength of ASTM A516 Grade 70 steel, namely 480 to $620 \mathrm{MPa}(70,000$ to $90,000 \mathrm{psi}) .{ }^{A 9}$ The difference of approximately 410 to $550 \mathrm{MPa}(60,000$ to $80,000 \mathrm{psi})$ between the maximum design longitudinal stress and the specified ultimate tensile stress ensures that circumferential fracture will not occur in normal circumstances. The circumferential path of the fracture indicates that intended design conditions did not prevail at the time of rupture. According to Equation A1 in Section 2.3.2, the deviation from design conditions might have been a decrease in wall thickness below the minimum allowable wall thickness. Perhaps an increase in pressure ( $P$ in Equation $A 1$ ) above normal operating pressure occurred in combination with a decrease in wall thickness.

\footnotetext{
*This stress is one-half of the maximum design hoop stress of $2.5 \mathrm{MPa}$ $(17,500 \mathrm{psi})$ cited in Table USC-23/Section VIII-ASME Boiler and Pressure Vessel Code. A
} 
There is a third possibility, namely, the existence of a circumferential zune of unusually low fracture resistance (low toughness) in the structural material in the region that became the fracture path. Localized deterioration of the fracture resistance of structural material, 1.e., a loss of toughness, could have occurred from the heating effects of welding and/or action of corrosive fluids. Indeed, much of the fracture surface was in the weld heat-affected zone* and simultaneously at a location where highly corrosive fluids were concentrated inside the pressure vessel. Excessive corrosion was known to occur at this location in the early life of the pressure vessel, as evidenced by such remedial measures as replacement of Shell Course 2 six years after initial construction (see Section 3.2) and by installation of the internal metal liner in May 1976 (see Section 3.4).

It can be speculated that a circumferential zone of low fracture resistance might also have developed from galvanic corrosion involving the Monel internal liner, the pressure vessel steel, and the fluids inside the pressure vessel. Extensive analysis is required to evaluate this speculation about galvanic corrosion.

It can also be speculated that a circumferential zone of low fracture resistance might have developed from local refrigeration associated with vaporizing and expanding hydrocarbons jetting from a leak. Local cooling of the steel could result from supplying the heat of vaporization and/or from the Joule-Thompson cooling associated with expanding gas. Such local cooling might have decreased the temperature in the vicinity of the growing leak to below the ductile-to-brittle transition temperature of the steel,

\footnotetext{
*There may be three heat-affected zones to consider. The first would have been created when Shell Course 1 and Replacement Shell Course 2 were welded together in 1974. The second would have been created when the internal metal liner was welded to the inside wall in the vicinity of the first heataffected zone in 1976. The heat-affected zone associated with the liner might overlap the first heat-affected zone. A third heat-affected zone might exist on Shell Course 1 from the time when it and the original shell course 2 were joined during original construction, or from the time when these two Shell Courses were separated in 1974.
} 
thereby creating a zone of low fracture resistance at the circumferentially growing crack front.* Extensive analysis is required to evaluate this speculation about localized cooling.

In summary, the possible causes of a circumferential zone of low fracture resistance include:

a. Low toughness in the heat-affected zone of the shell steel caused by heating associated with the girth welding at the time of initial construction when replacement shell Course 2 was installed and/or when the internal metal liner was installed

b. Deterioration of the heat-affected zone by corrosion, e.g., blister cracking, on the inside wall due to exposure to hydrogen sulfide

c. Low toughness of steel at the leak due to localized cooling from vaporization of liquid hydrocarbons and/or Joule-Thompson cooling associated with jetting hydrocarbons causing local temperature at the leak to fall below the ductile-brittle transition temperature of the steel

Further study of the fracture beyond the visual observations cited in Sections 4.1 thorugh 4.3 is necessary to reach a satisfactory explanation of the cause of fracture. In view of the severe distortion of the fracture surface on the upper portion of pressure vessel 120701 after the fracture it seems reasonable to focus initial investigative efforts on the undistorted fracture surface on the lower portion. This latter fracture surface is probably more representative of conditions at the time of rupture, despite heating from the refinery fires on July 23, 1984.

*During the field investigation, refinery employees mentioned that it is common refinery practice to spray steam on a leak. 


\subsection{DISCUSSION}

\subsection{PROBABLE CAUSE OF THE REFINERY INCIDENT}

It appears that the rupture of pressure vessel 12D701 was the initiating event that led to the fires and extensive damage at the south end of the Union oil Company petroleum refinery in Lemont, Illinois on July 23, 1984. The principal evidence available during the field investigation in support of this view was the eyewitness report (see Section 1.2.2).

\subsection{THROUGH-WALL DEFECT IN PRESSURE VESSEL 12D701}

The observation of a leak (see Section 1.2.2) implies the presence of a through-wall defect. It is not known how long it took for the defect to develop and penetrate the wall. However, it can be said that the time interval for development of the through-wall defect was between the spring of 1974, when replacement Shell Course 2 was installed and July 23, 1984 when complete wall penetration led to a visible leak. Equipment Inspection Reports ${ }^{A 5}$ indicate more deterioration by corrosion of Shell Course 1 than replacement Shell Course 2 during this time interval.

The possibility exists that the through-wall defect developed over a short period of time and was due to causes other then corrosion. However, plausible explanations for development of a through-wall defect in a short time period were not reported during the field investigation.

\subsection{CIRCUMFERENTIAL SEPARATION IN THE VICINITY OF A GIRTH WELD}

Pressure vessel 12D701 ruptured into two major pieces via a separation occurring along a circumferential fracture path that closely followed most of the girth weld joining Shell Course 1 and replacement Shell course 2 (see Sections 1.2.3 and 3.2.1. for a more complete description). A circumferential fracture path in an internally pressurized cylindrical shell is an unexpected occurrence. It indicates that the rupture occurred in response to longitudinal tensile stress, not circumferential tensile stress, which is twice as large as the longitudinal tensile stress for a given internal 
pressure. The circumferential fracture path suggests the existence of a highly localized, circumferentially oriented zone of unexpectedly low resistance to fracture under longitudinal stress. Since the fracture path closely followed most of the girth weld joining Shell course 1 and replacement Shell Course 2, the region of the girth weld* is a candidate zone for mechanical, metallurgical, and fractographical examination to see if it might be a zone of low fracture resistance.

\subsection{CORROSION OF PRESSURE VESSEL 12D70 1}

\subsubsection{Corrosion Caused by Hydrogen Sulfide}

The function of pressure vesse 1 12D701 in the refinery process was to remove hydrogen sulfide from a liquid hydrocarbon stream (see section 1.2.4). Hydrogen Sulfide in known to be corrosive to steel under the operating conditions of the pressure vessel; consequently, this pressure vessel was designed with a corrosion allowance amounting to a $3 \mathrm{~mm}$ (1/8 in.) wall thickness above that required to sustain internal pressure. $\mathrm{A} 3$

Equipment Inspection Reports ${ }^{A 5}$ showed that pressure vessel 12D701 sustained substantial corrosion cracking (blister cracking) on the inside walls in the vicinity of the inlet piping near the bottom of the vessel. The piping introduced a hydrogen-sulfide-rich hydrocarbon stream into the vessel. The deterioration via corrosion was a continuous process during the life of the vessel, which was so severe as to require: 1) replacement of the original Shell Course 2 in 1976 after six years of service, 2) installation of a Monel internal liner in 1976 to protect Shell Course 1 and the bottom head, and 3) weld repair of the corroded Monel liner in April 1984.

The rupture of pressure vessel 12D701 on July 23, 1984 due to longitudinal stress from internal pressure suggests that all corrosion processes causing deterioration were not being adequately monitored and counteracted. The focus of refinery inspection was usually on blister cracking. Other corrosion processes, e.g., galvanic corrosion, should also be considered.

*The region of the girth weld includes the weld metal, the heat-affected zone of the base plate, and the unaffected base plate near the weld. 


\subsubsection{Galvanic Corrosion}

It may be speculated that galvanic corrosion might have occurred between the Monel Liner and the shell plate steel. The necessary electrical contact between the liner and shell was ensured by welding the liner to the shell. It is plausible that the process fluids could have acted as an electrolyte. It is also plausible that Monel is more noble that the shell plate steel, setting the stage for anodic solution of iron in the steel.

This speculation about possible galvanic corrosion needs to be evaluated by experimental measurements directly on the Monel from the liner shell steel, which was in contact with the Monel and typical process fluids.

\subsection{INFORMATION NEEDED FOR ASSESSMENT OF FRACTURE}

Some aspects of the girth weld joining Shell Course 1 and replacement Shell Course 2 are described in Sections 2.3.1,3.3, and 3.4. Only very limited information about this region of pressure vessel 120701 was available during the field investigation. Much more information is needed to assess the possible causes of low fracture resistance listed in Section 4.4 or to assess other possible causes of fracture.

Records needed include all available construction and materials specifications, all maintenance and repair specifications, all welding procedures, and all inspection reports dating from the time the pressure vessel was constructed. Of particular interest would be information in these records pertaining to Shell Course 1 and replacement Shell Course 2.

Records describing operating conditions prior to and at the time of rupture are also needed. Of particular interest would be information on pressure, temperature, and chemical composition of process fluids.

Finally, records describing valve specifications and valve inspection reports are needed.

In addition to the foregoing records, a substantial amount of technical data needs to be generated on the structural material specimens taken from the 1) heat-affected zone, 2) weld metal, 3) base plate and 4) Monel internal liner of the ruptured pressure vessel, specifically: 
a. Unambiguous identification of the origin of fracture

b. Results of nondestructive inspection of cracks in the vicinity of the fracture surface

c. Measurements of wall thickness in the vicinity of the fracture surface (see Table AII for minimum required thickness according to Table USC-23 Section VIII of the ASME Boiler and Pressure Vessel Code)

d. Chemical composition of metal samples taken near the fracture

e. Metallographic and fractographic analysis of specimens taken from the fracture surface and nearby regions

f. Mechanical properties of test specimens taken from the ruptured pressure vessel. Properties of interest include tensile properties, hardness, and especially, toughness

g. Theoretical fracture mechanics analysis of part-through and throughwall circumferential cracks

h. Results of testing model structures, if needed

i. Theoretical fluid mechanics analysis to assess refrigeration effects on toughness of a through-wall leak

j. Corrosion test results assessing the effects of process fluids on structural material

k. Corrosion test results assessing the extent of galvanic corrosion effects between the Monel internal liner and the pressure vessel steel in the presence of process fluids

Expert technical analysis will be required of the records and the units of these tests. 


\subsection{CONCLUSIONS}

6.1 The rupture of pressure vesse 1 12D701, a 16 year old, $16 \mathrm{~m}$ (55 ft.) high amine absorber tower constructed in 1968, was the initiating event that led to the fires and extensive damage at the south end of the Union Oil Petroleum Refinery in Lemont, Illinois on July 23, 1984.

6.2 The rupture of pressure vessel 12D701 originated at a crack that leaked. Longitudinal tensile stress from internal pressure caused the through-wall defect at the leak to grow circumferentially and to separate the vessel into two major pieces. The circumferential fracture followed a path of low fracture resistance in the vicinity of the girth weld joining shell Course 1 and replacement Shell Course 2 .

6.3 The through-wall defect at the leak developed sometime between May 1974, when replacement Shell Course 2 was welded into place, and July 23, 1984 when the leak was reported.

6.4 Pressure vessel 12D701 sustained substantial corrosion cracking (blister cracking) on the inside walls in the vicinity of the inlet piping near the bottom of the vessel. The deterioration via corrosion was a continuing process during the life of the vessel, which was so severe as to require replacement of the original Shell Course 2 in 1974 after six years of service, protection of Shell Course 1 and the bottom head with a Monel interior liner in 1976, and weld repair of the corroded liner in April 1984.

6.5 By 1972, wall thickness of the original Course 2 of pressure vessel 12 D701 had been deteriorated by corrosion to values as much as 30\% less than the minimum wall thickness required by the ASME Boiler and Pressure Vessel Code.

6.6 Numerous refinery records and much technical data and analysis, as described in Section 5.4 of this report, are needed to facilitate an important assessment of the causes of the catastrophic fracture of pressure vessel 12D701. 
A1. Preliminary NBS Reports to OSHA/U.S. Department of Labor.

a) "Preliminary Report of NBS Field Investigation of Incident at Union Oil Company's Refinery at Lockport, Illinois on July 23, 1984." To Mr. William Funcheon, Calumet City Area Office, Calumet City, Illinois 60409. August 10, 1984.

b) "Incident at Union Oil Company's Chicago Refinery, Lockport, Illinois on July 23, 1984." To Mr. Frank Strasheim, Chicago Regional Office, Chicago, Illinois 60604. August 29, 1984.

National Bureau of Standards, Boulder, Colorado.

A2. Engineering drawing for Union Oil Company at Lemont, Illinois - Chicago Refinery - Unsaturated Gas Unit 12 - Plot Plan. C. F. Braun and Co., Alhambra, California. November 22, 1967.

A3. Engineering drawing for "(1) Unsaturated $C_{3}-C_{4}$ Amine Absorber" for Union Oil Company, Lemont, Illinois and C.F. Braun and Company, Alhambra, California. Buffalo Tank Division, Bethlehem Steel Corporation. August 12, 1968 .

A4. 1968 ASME Boiler and Pressure Vessel Code. Section VIII - Division 1.

a) Paragraph UG-27/Thickness of shells under internal pressure.

b) Paragraph UG-32/formed heads, pressure on concave side.

c) Table USC-23/Maximum Allowable stress values in tension for carbon and low-alloy steel.

d) Paragraph UG-25/corrosion.

ASME, New York. 1968.

A5. Equipment Inspection Reports: April 1972; April 1974; May 1976; April $1978 \mathrm{~T} / \mathrm{A} ; 1980 \mathrm{~T} / \mathrm{A} ; 1982 \mathrm{~T} / \mathrm{A}$; April $1984 \mathrm{~T} / \mathrm{A}$. Provided by refinery employees in July 1984 to Compliance Officers from OSHA Area Office in Calumet City, Illinois.

A6. "Blisters in the $\mathrm{C}_{3}-\mathrm{C}_{4}$ Amine Absorber." Letter report from Mr. E. Schaschl, Engineering Associate, Union Research Center, Brea, California to Mr. Hans Kolff van Oosterwijk, Chicago Refinery, Lemont, Illinois. May 3, 1972.

A7. "C $\mathrm{C}_{3}-\mathrm{C}_{4}$ Amine Absorber and Fuel Gas Contactor". Memorandum report from R. Y. Salisbury, Inspection Division, Union Oil Company of California to J. E. Ganzman, Operations Division, Union Oil Company of California. June 26, 1972.

A8. "Inspection Report, March 1974 T/A, UNSAT Gas Plant No. 212." Memorandum report from L. W. Virtel, Inspection Supervisor, Union Oil Company of California to Mr. H. Kolff van Oosterwijk, Chicago Refinery, Lemont, Illinois. September 5, 1974.

A9. ASTM Designation A516: Standard Specification for Pressure Vessel Plates, Carbon Steel, for Moderate-and Lower-Temperature Service. American Society for Testing and Materials, 1.916 Race Street, Philadelphia, Pennsylvania. 
APPENDIX B - MAGNETIC PARTICLE INSPECTION

December 1985

Prepared by: J. David McColskey

David T. Read

Thomas A. Siewert

Fracture and Deformation Division

Institute for Materials Science and Engineering National Bureau of Standards

Boulder, Colorado 80303 

Table BI. Magnetic particle inspection of Ring 1, Course 1.

\section{Location}

\begin{tabular}{ll}
\hline Circumference & Base Metal, \\
& Weld, or HAZ \\
& and Course \\
& Number
\end{tabular}

Number
BM 1

BM 1

BM 1

BM 1

0.45

$0.43-0.55$

$0.55-0.65$

$0.65-0.80$

0.77

0.85

0.85

0.88

$0.91-1.07$

1.09

BM 1

BM 1
Length

Indications

$\mathrm{mm}$

6

$-30$

3-6

$-36$

6

6

$\leqq 9$

$-25$

$3-19$

4

BM 1 (cutout)

$\leqq 6$

$-25$

25

13

3

3

3

8

$B$

- base metal

HAZ - heat affected zone

i.d. - inside diameter (surface)
Comments

Edge of feed-through pipe, $6 \mathrm{~mm}$ to $102 \mathrm{~mm}$ from $F S$

$13 \mathrm{~mm}$ to $89 \mathrm{~mm}$ from $\mathrm{FS}$

$3 \mathrm{~mm}$ from $\mathrm{FS}$

$9 \mathrm{~mm}$ from $\mathrm{FS}$

$3 \mathrm{~mm}$ to $76 \mathrm{~mm}$ FS

Splitting on edge of cutout, $19 \mathrm{~mm}$ from FS

$13 \mathrm{~mm}$ to $76 \mathrm{~mm}$ from $\mathrm{ES}$

$19 \mathrm{~mm}$ be low FS

$19 \mathrm{~mm}$ below FS

$6 \mathrm{~mm}$ below FS

At vertical fillet we ld, $13 \mathrm{~mm}$ from $\mathrm{FS}$

Three are $3 \mathrm{~mm}$ long; five are $6 \mathrm{~mm}$ long, $13 \mathrm{~mm}$ to $64 \mathrm{~mm}$ from FS (Monel liner starts here).

$38 \mathrm{~mm}$ from $\mathrm{FS}$ 
Table BI, continued

\section{Location}

\begin{tabular}{lllll}
\hline Circumference & Base Metal, & Length & Indications & Comments \\
Weld, or HAZ & $m m$ & \\
& and Course & & \\
& Number &
\end{tabular}

1.42

BM 1

10

1

13

1

$\begin{array}{llc}1.46 & \text { BM } 1 & 13 \\ 1.59-2.04 & \text { BM } 1 \text { (cutout) } & 6-25\end{array}$

$2.04-2.18$

BM 1

9

15

2.06

BM 2

$2.21-2.34$

BM 1

$2.36-2.44$

BM 1

2.68

BM 1

$2.84-3.06$

HAZ 1
Apparent blister, $13 \mathrm{~mm}$ from $F S$

$114 \mathrm{~mm}$ from $\mathrm{FS}$

Multiple splitting indications on edges of cutouts.

$25 \mathrm{~mm}$ to $152 \mathrm{~mm}$ FS

$3 \mathrm{~mm}$ from FS surface.

$25 \mathrm{~mm}$ to $127 \mathrm{~mm}$ from $\mathrm{FS}$

$13 \mathrm{~mm}$ to $76 \mathrm{~mm}$ from $\mathrm{FS}$

$25 \mathrm{~mm}$ from $\mathrm{FS}$

Indications at fusion line of Monel attachment weld, and intermittent indications along fusion line of HAZ 1 .

$13 \mathrm{~mm}$ from $\mathrm{FS}$

Vertical weld for tray $r$ ib has 4 indications transverse to fillet weld. Located at $32 \mathrm{~mm}, 127 \mathrm{~mm}, 184 \mathrm{~mm}$, and $229 \mathrm{~mm}$ below girth weld (Monel liner stops here). 
Location

\begin{tabular}{lllll}
\hline Circumference & Base Metal, Length & Indications & Comments \\
& Weld, or HAZ & $\mathrm{mm}$ & \\
and Course & & \\
& Number & &
\end{tabular}

\section{$3.57-3.66$}

BM 1 (cutout)

$22-51$

\subsection{7}

3.71

3.78

3.84

$3.84-4.09$

4.05

4.11

$4.11-4.15$

$4.17-4.18$

4.22

4.24

4.24

4.27

4.27

$4.28-4.37$

$4 \cdot 31$
BM 1

BM 1

BM 1

BM 1

HAZ 1

BM 1

BM 1

HAZ 1

HAZ 1

BM 1

BM 1

HAZ 1

HAZ 1

BM 1

BM 1 (cutout)

Vertical weld
$6-25$

11

$3-6$

13

6

19

250

6

6

38

19

9

$3-6$

25

13

$3-13$

4

1

6
Multiple splitting, about $3 \mathrm{~mm}$ from i.d. along sawcut edges

Multiple indications, $19 \mathrm{~mm}$ to $76 \mathrm{~mm}$ from $\mathrm{FS}$

$50 \mathrm{~mm}$ from $\mathrm{FS}$

$50 \mathrm{~mm}$ from $\mathrm{ES}$

$25 \mathrm{~mm}$ from $\mathrm{FS}$

Along HAZ 1

$50 \mathrm{~mm}$ below FS

$25 \mathrm{~mm}$ and $38 \mathrm{~mm}$ below FS

$6 \mathrm{~mm}$ below FS

Multiple indications, $6 \mathrm{~mm}$ to $50 \mathrm{~mm}$ below FS

\section{Extends to cutout}

$50 \mathrm{~mm}$ to $76 \mathrm{~mm}$ below FS

Multiple splitting within $3 \mathrm{~mm}$ of i.d. along saw-cut edge of cutout.

$3 \mathrm{~mm}$ to $50 \mathrm{~mm}$ below cutout surface 


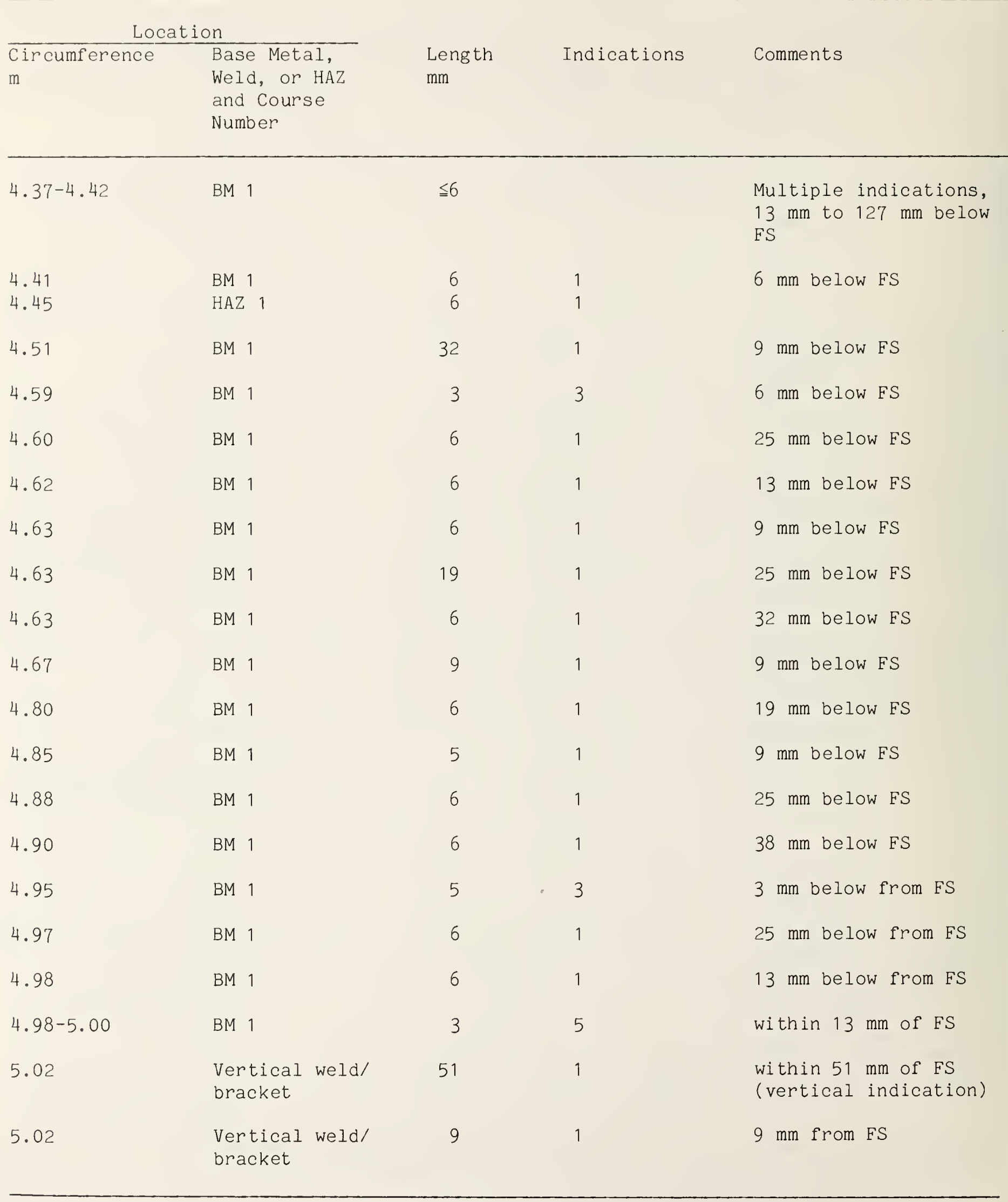




\section{Location}

\begin{tabular}{lllll}
\hline Circumference & Base Metal, & Length & Indications & Comments \\
& Weld, or HAZ & $\mathrm{mm}$ & \\
& and Course & & \\
& Number &
\end{tabular}

5.02

Vertical weld/

bracket

5.03

BM 1

16

5.41

BM 1

BM 1

BM 1

BM 1

70

BM 1

$$
9
$$

BM 1

5.76

BM 1

5.91

6.30

BM 1

6.72

HAZ

6.91

BM 1

6.91

BM 1

BM 1

BM 1

BM 1

BM 1

BM 1

BM 1

BM 1
$6 \mathrm{~mm}$ to $22 \mathrm{~mm}$ below FS

5

5

6

9

1

$29 \mathrm{~mm}$ from $\mathrm{FS}$

$25 \mathrm{~mm}$ below FS

$9 \mathrm{~mm}$ below FS

$3 \mathrm{~mm}$ below FS

$44 \mathrm{~mm}$ below FS

$50 \mathrm{~mm}$ below FS

$3 \mathrm{~mm}$ below FS

$102 \mathrm{~mm}$ below FS

$3 \mathrm{~mm}$ below FS

$3 \mathrm{~mm}$ below FS

$9 \mathrm{~mm}$ below FS

$29 \mathrm{~mm}$ below FS

$6 \mathrm{~mm}$ below FS

$3 \mathrm{~mm}$ below FS

$13 \mathrm{~mm}$ below ES

$16 \mathrm{~mm}$ below FS

$19 \mathrm{~mm}$ below FS

$29 \mathrm{~mm}$ below FS 
Table BI, continued

\begin{tabular}{lllll}
$\begin{array}{l}\text { Circumference } \\
\mathrm{m}\end{array}$ & $\begin{array}{l}\text { Base Metal, } \\
\text { Weld, or HAZ } \\
\text { and Course } \\
\text { Number }\end{array}$ & $\begin{array}{l}\text { Length } \\
\mathrm{mm}\end{array}$ & Indications & Comments \\
\hline 7.22 & BM 1 & 27 & 1 & $35 \mathrm{~mm}$ below FS \\
7.22 & BM 1 & $3-13$ & $\begin{array}{l}\text { Multiple indications, } \\
38 \mathrm{~mm} \text { to } 89 \text { mm below }\end{array}$
\end{tabular}

$7.23-8 \cdot 3$

- 
Table BII. Magnetic particle inspection of Ring 2, Course 2

\begin{tabular}{|c|c|c|c|c|}
\hline LOS & & & & \\
\hline Circumference & $\begin{array}{l}\text { Base Metal, } \\
\text { Weld, or HAZ } \\
\text { and Course } \\
\text { Number }\end{array}$ & $\begin{array}{l}\text { Leng th } \\
\mathrm{mm}\end{array}$ & Indications & Comments \\
\hline
\end{tabular}

\begin{tabular}{|c|c|c|c|c|}
\hline 0.03 & BM 2 (cutout) & 57 & 1 & $\begin{array}{l}127 \mathrm{~mm} \text { above FS (on } \\
\text { saw cut) }\end{array}$ \\
\hline 0.03 & BM 2 (cutout) & 5 & 1 & $13 \mathrm{~mm}$ above $\mathrm{FS}$ \\
\hline 0.03 & BM 2 (cutout) & 5 & 1 & $\begin{array}{l}83 \mathrm{~mm} \text { above FS (on } \\
\text { saw cut) }\end{array}$ \\
\hline 0.03 & BM 2 & 6 & 1 & $32 \mathrm{~mm}$ above FS \\
\hline 0.03 & BM 2 & 6 & 1 & $25 \mathrm{~mm}$ above FS \\
\hline 0.03 & BM 2 & 13 & 1 & $89 \mathrm{~mm}$ above FS \\
\hline 0.03 & BM 2 & 6 & 1 & $108 \mathrm{~mm}$ above FS \\
\hline 0.03 & BM 2 & 6 & 1 & $121 \mathrm{~mm}$ above FS \\
\hline 0.04 & BM 2 & 44 & 1 & $\begin{array}{l}70 \mathrm{~mm} \text { from } \mathrm{FS} \text {, at fu- } \\
\text { sion line of flange } \\
\text { weld }\end{array}$ \\
\hline 0.04 & BM 2 & $1-6$ & & $\begin{array}{l}\text { Multiple indications } \\
\text { from FS to } 152 \mathrm{~mm} \text { above } \\
\text { FS }\end{array}$ \\
\hline 0.16 & HAZ 2 & 22 & 1 & \\
\hline 0.16 & BM 2 & 64 & 1 & $19 \mathrm{~mm}$ above FS \\
\hline 0.38 & BM 2 & 50 & 1 & $25 \mathrm{~mm}$ above FS \\
\hline 0.50 & BM 2 & 3 & 1 & $35 \mathrm{~mm}$ above FS \\
\hline
\end{tabular}

FS - fracture surface

BM - base metal

HAZ - heat affected zone

i.d. - inside diameter (surface) 


\begin{tabular}{|c|c|c|c|c|}
\hline LOS & & & & \\
\hline $\begin{array}{l}\text { Circumference } \\
\text { m }\end{array}$ & $\begin{array}{l}\text { Base Metal, } \\
\text { Weld, or HAZ } \\
\text { and Course } \\
\text { Number }\end{array}$ & $\begin{array}{l}\text { Length } \\
\mathrm{mm}\end{array}$ & Indications & Comments \\
\hline
\end{tabular}

\section{$0.55-0.64$}

\subsection{7}

0.70

$0.64-0.87$

\subsection{5}

0.99

1.03

1.03

1.03

1.03

1.04

1.04

$1.04-1.27$

1.24

1.30

$1 \cdot 31$

1.38

1.42
BM 2 (cutout)

HAZ 2

BM 2

Weld $1 / 2$

BM 2

HAZ 2

HAZ 2

BM 2

BM 2

BM 2

BM 2

BM 2

HAZ 2

BM 2

BM 2

HAZ 2

HAZ 2

BM 2

$3-9 \quad 3$

3

9

3

25

9

165

22

9

6

9

9

178

9

76

32

13

13
Splitting indications

on saw-cut surfaces

$32 \mathrm{~mm}$ from $\mathrm{FS}$

$38 \mathrm{~mm}$ above FS

Multiple transverse cracks in weld, $6 \mathrm{~mm}$ to $32 \mathrm{~mm}$ above FS

$35 \mathrm{~mm}$ above FS

$25 \mathrm{~mm}$ above FS

$25 \mathrm{~mm}$ above FS

$38 \mathrm{~mm}$ above FS

$35 \mathrm{~mm}$ above FS

$32 \mathrm{~mm}$ above FS

$32 \mathrm{~mm}$ above FS

$51 \mathrm{~mm}$ above FS

Apparent continuous indication $32 \mathrm{~mm}$ above FS

$57 \mathrm{~mm}$ above FS

$51 \mathrm{~mm}$ above FS

$32 \mathrm{~mm}$ above FS

$51 \mathrm{~mm}$ from FS

$57 \mathrm{~mm}$ above FS 


\section{Location}

\begin{tabular}{lllll}
\hline Circumference & Base Metal, & Length & Indications & Comments \\
Weld, or HAZ & mm & \\
and Course & & & \\
& Number & &
\end{tabular}

1.45

BM 2

6

1

$44 \mathrm{~mm}$ from $\mathrm{FS}$

1.46

BM 2

$3-6$

1.59

BM 2

6

1

1.63

BM 2

6

BM 2 (cutout)

6

Multiple indications, $25 \mathrm{~mm}$ above FS

$89 \mathrm{~mm}$ from FS

$86 \mathrm{~mm}$ above FS

$1.69-1.76$

BM 2

6

1

BM 2

6

1

BM 2

6

BM 2

5

6

HAZ 2

HAZ 2

3

13

BM 2

BM 2

9

1

2.28

BM 2

9

BM 2

9

BM 2

HAZ 2

2.34
6

6
Bottom of cutout, open to inner surface of vessel

$76 \mathrm{~mm}$ from $\mathrm{FS}$

$76 \mathrm{~mm}$ from $\mathrm{FS}$

$102 \mathrm{~mm}$ above FS

$6 \mathrm{~mm}$ from $\mathrm{FS}$

$13 \mathrm{~mm}$ from $\mathrm{FS}$

$19 \mathrm{~mm}$ from $\mathrm{FS}$

$64 \mathrm{~mm}$ above FS, possi

ble blister

$38 \mathrm{~mm}$ above FS, possible blister

$44 \mathrm{~mm}$ above FS

$44 \mathrm{~mm}$ above FS

$41 \mathrm{~mm}$ above FS

$25 \mathrm{~mm}$ above FS 


\begin{tabular}{|c|c|c|c|c|}
\hline \multicolumn{2}{|c|}{ Location } & \multirow[b]{2}{*}{$\begin{array}{l}\text { Length } \\
\mathrm{mm}\end{array}$} & \multirow[b]{2}{*}{ Indications } & \multirow[b]{2}{*}{ Comments } \\
\hline $\begin{array}{l}\text { Circumference } \\
\text { m }\end{array}$ & $\begin{array}{l}\text { Base Metal, } \\
\text { Weld, or HAZ } \\
\text { and Course } \\
\text { Number }\end{array}$ & & & \\
\hline 2.35 & HAZ 2 & 6 & 1 & $25 \mathrm{~mm}$ above FS \\
\hline 2.35 & BM 2 & 6 & 1 & $38 \mathrm{~mm}$ above FS \\
\hline 2.41 & BM 2 & 19 & & $\begin{array}{l}\text { Multiple indications, } \\
38 \mathrm{~mm} \text { above FS }\end{array}$ \\
\hline $2.39-2.44$ & Weld $1 / 2$ & 50 & 1 & $\begin{array}{l}\text { Monel/weld interface, } \\
6 \mathrm{~mm} \text { above FS }\end{array}$ \\
\hline 2.48 & BM 2 & 6 & 1 & $44 \mathrm{~mm}$ above FS \\
\hline 2.60 & Weld $1 / 2$ & 89 & 1 & $\begin{array}{l}\text { Monel/weld interface, } \\
25 \mathrm{~mm} \text { below } \mathrm{FS}\end{array}$ \\
\hline 2.64 & HAZ 2 & 6 & 1 & $32 \mathrm{~mm}$ above FS \\
\hline 2.65 & HAZ 2 & 6 & 1 & $32 \mathrm{~mm}$ above FS \\
\hline 2.65 & BM 2 & 5 & 1 & $44 \mathrm{~mm}$ above FS \\
\hline 2.67 & HAZ 2 & & 1 & $\begin{array}{l}\text { Large, open crack at } \\
\text { HAZ } 2\end{array}$ \\
\hline 2.67 & BM 2 & 13 & 1 & $44 \mathrm{~mm}$ above FS \\
\hline 2.68 & BM 2 & 6 & 1 & $57 \mathrm{~mm}$ above FS \\
\hline 2.73 & BM 2 & 6 & 1 & $22 \mathrm{~mm}$ above FS \\
\hline 2.86 & BM 2 & 6 & 1 & $6 \mathrm{~mm}$ from $\mathrm{ES}$ \\
\hline 2.92 & BM 2 & 13 & 1 & $29 \mathrm{~mm}$ above FS \\
\hline 3.07 & BM 2 & 16 & 1 & $19 \mathrm{~mm}$ from $\mathrm{FS}$ \\
\hline 3.07 & BM 2 & 6 & 1 & $32 \mathrm{~mm}$ above FS \\
\hline 3.15 & BM 2 & 16 & 1 & $32 \mathrm{~mm}$ above FS \\
\hline
\end{tabular}




\section{Location}

$\begin{array}{lllll}\text { Circumference } & \text { Base Metal, } & \text { Length } & \text { Indications } & \text { Comments } \\ & \text { Weld, or HAZ } & m m & \\ \text { and Course } & & & \\ & \text { Number } & & \end{array}$

$3.23-3.59$

Weld $1 / 2$

$\leqq 13$
$3.59-3.69$
BM 2 (cutout)
83,25
2
$3.71-3.94$
HAZ 2

4.27

HAZ 2

HAZ 2

BM 2 (cutout)

HAZ 2

8

13

HAZ 2

HAZ 2

\section{9}

Weld $1 / 2$

13

HAZ 2

8

Weld $1 / 2$, BM 2

19

16

HAZ 2

We ld $1 / 2$

$3-6$

$5.84-6.25$

5.89

HAZ 2
Multiple transverse indications at HAZ 2; multiple indications parallel to weld, some about $13 \mathrm{~mm}$ long

On saw-cut surfaces, $83 \mathrm{~mm}$ indication at $3.59 \mathrm{~m}, 6 \mathrm{~mm}$ above FS, and $25 \mathrm{~mm}$ indication at $3.59 \mathrm{~m}, 16 \mathrm{~mm}$ above FS (splitting indications)

Indications at $3.71 \mathrm{~m}$, $3.85 \mathrm{~m}$, and $3.89 \mathrm{~m}$

$19 \mathrm{~mm}$ above FS (saw-cut edge)

$29 \mathrm{~mm}$ from FS

$29 \mathrm{~mm}$ from $\mathrm{FS}$

$29 \mathrm{~mm}$ from FS

$6 \mathrm{~mm}$ from $\mathrm{FS}$

$32 \mathrm{~mm}$ from $\mathrm{FS}$

Transverse to weld, $19 \mathrm{~mm}$ above FS

$29 \mathrm{~mm}$ from FS

Multiple transverse cracks in weld

$32 \mathrm{~mm}$ above FS 
Table BII, continued

Location

\begin{tabular}{|c|c|c|c|c|}
\hline $\begin{array}{l}\text { Circumference } \\
\text { m }\end{array}$ & $\begin{array}{l}\text { Base Metal, } \\
\text { Weld, or HAZ } \\
\text { and Course } \\
\text { Number }\end{array}$ & $\begin{array}{l}\text { Length } \\
\mathrm{mm}\end{array}$ & Indications & Comments \\
\hline 5.92 & HAZ 2 & 19 & 1 & $32 \mathrm{~mm}$ above FS \\
\hline 5.94 & HAZ 2 & 25 & 1 & $32 \mathrm{~mm}$ above FS \\
\hline 6.18 & HAZ 2 & 19 & 1 & $30 \mathrm{~mm}$ above FS \\
\hline $6.22-6.27$ & HAZ 2 & & & $\begin{array}{l}\text { Multiple small indica- } \\
\text { tions, } 30 \mathrm{~mm} \text { above FS }\end{array}$ \\
\hline $6.38-6.63$ & Weld $1 / 2$ & 6 & & $\begin{array}{l}\text { Multiple transverse } \\
\text { indications in weld }\end{array}$ \\
\hline $6.43-6.99$ & HAZ 2 & & & Multiple indications \\
\hline $7.16-7.66$ & BM 2 (cutout) & & & No indications \\
\hline $7.66-8.3$ & & & & No indications \\
\hline
\end{tabular}

Vertical weld A has no indications.

Vertical weld $B$ has one indication (vertical) $330 \mathrm{~mm}$ above cutout, $6 \mathrm{~mm}$ long. Vertical weld $C$ has one $3 \mathrm{~mm}$ indication, $22 \mathrm{~mm}$ above cutout. 
Table BIII. Magnetic particle inspection of Ring 3, Course 2/3

\section{Location}

$\begin{array}{lllll}\text { Circumference } & \text { Base Metal, Length } & \text { Indications } & \text { Comments } \\ \mathrm{m} & \text { Weld, or HAZ } & \mathrm{mm} & \\ & \text { and Course } & & \end{array}$

Number

$\begin{array}{llcr}0.01 & \text { BM 3 } & 3 & 3 \\ 0.28 & \text { BM } 3 & 13 & 1 \\ 0.32 & \text { HAZ } 2 & 6 & 1 \\ 0.43 & \text { HAZ } 2 & 19 & 1 \\ 0.47 & \text { BM 3 } & 3 & 5 \\ 0.60 & \text { HAZ } 3 & 6 & 1 \\ 0.55 & \text { HAZ } 3 & 13 & 1 \\ 0.62 & \text { BM 3 } & 6 & 1 \\ 0.62-0.63 & \text { HAZ 2 } & 114 & 1 \\ 0.65 & \text { HAZ 2 } & 13 & 1\end{array}$

0.84

NBS CUTOUT FOR SPECIMENS BEGINS HERE

1.14

BM 2

Arc strike, $6 \mathrm{~mm}$ from weld

$2.41 \quad$ BM 3

Arc strike, $13 \mathrm{~mm}$ from weld

BM 3

Arc strike, $13 \mathrm{~mm}$ from weld

2.90

NBS CUTOUT FOR SPECIMENS ENDS HERE
2.94
BM 3
9
$6 \mathrm{~mm}$ from weld
2.96
BM 3
$9 \quad 1$
$13 \mathrm{~mm}$ from weld
2.98
BM 3
6
3
$6 \mathrm{~mm}$ from weld
2.98
BM 2
3
$3 \mathrm{~mm}$ from wold 


\begin{tabular}{|c|c|c|c|c|}
\hline \multicolumn{2}{|c|}{ Location } & & & \\
\hline $\begin{array}{l}\text { Circumference } \\
\mathrm{m}\end{array}$ & $\begin{array}{l}\text { Base Metal, } \\
\text { Weld, or HAZ } \\
\text { and Course } \\
\text { Number }\end{array}$ & $\begin{array}{l}\text { Length } \\
\mathrm{mm}\end{array}$ & Indications & Comments \\
\hline
\end{tabular}

\begin{tabular}{|c|c|c|c|c|}
\hline 3.00 & BM 3 & 3 & 2 & $19 \mathrm{~mm}$ from weld \\
\hline 3.02 & BM 2 & 6 & 2 & $19 \mathrm{~mm}$ from weld \\
\hline 3.12 & BM 3 & 6 & 1 & $\begin{array}{l}\text { "X" shaped indication, } \\
13 \mathrm{~mm} \text { from weld }\end{array}$ \\
\hline 3.15 & $\mathrm{BM} 3$ & 6 & 2 & $6 \mathrm{~mm}$ from weld \\
\hline $3.15-3.28$ & AREA INACCESSIBLE & & & \\
\hline $3 \cdot 31$ & BM 2 & 3 & 1 & $6 \mathrm{~mm}$ from weld \\
\hline $3 \cdot 31$ & $\mathrm{BM} 3$ & 6 & 2 & $13 \mathrm{~mm}$ from weld \\
\hline $3.33-4.03$ & TORCHED CUTOUT & & & \\
\hline 4.03 & BM 3 & 13 & 2 & $\begin{array}{l}\text { At torch-cut edge of } \\
\text { cutout }\end{array}$ \\
\hline 4.09 & HAZ 3 & 6 & 1 & \\
\hline 4.09 & HAZ 2 & 3 & 1 & \\
\hline 4.14 & BM 2 & 9 & 1 & $6 \mathrm{~mm}$ from weld \\
\hline 4.19 & HAZ 2 & 19 & 1 & \\
\hline 4.24 & $\mathrm{BM} 3$ & 6 & 2 & $9 \mathrm{~mm}$ from weld \\
\hline $4 \cdot 27-4 \cdot 37$ & BM 3 & 6 & 11 & $13 \mathrm{~mm}$ from weld \\
\hline $4 \cdot 32$ & $\mathrm{BM} 2$ & 6 & 1 & $6 \mathrm{~mm}$ from weld \\
\hline 4.43 & BM 3 & 6 & 2 & $13 \mathrm{~mm}$ from weld \\
\hline 4.46 & BM 2 & 3 & 2 & $6 \mathrm{~mm}$ from weld \\
\hline 4.46 & BM 3 & 6 & 2 & $6 \mathrm{~mm}$ from weld \\
\hline 4.48 & $\mathrm{BM} 2^{\circ}$ & 6 & 1 & $9 \mathrm{~mm}$ from weld \\
\hline
\end{tabular}




\section{Location}

\begin{tabular}{|c|c|c|c|c|}
\hline $\begin{array}{l}\text { Circumference } \\
\mathrm{m}\end{array}$ & $\begin{array}{l}\text { Base Metal, } \\
\text { Weld, or HAZ } \\
\text { and Course } \\
\text { Number }\end{array}$ & $\begin{array}{l}\text { Length } \\
\mathrm{mm}\end{array}$ & Indications & Comments \\
\hline
\end{tabular}

4.53

4.58

4.59

$4.61-4.66$

$4.70-4.78$

4.80

4.83

4.86

$4.85-4.90$

4.89

4.91

4.97

4.97

4.92

$4.97-5.21$

$5.21-5.32$

5.22

$5.24-5.84$

5.26
4.83
BM 3

HAZ 3

HAZ 3

BM 3

BM 3

BM 3

BM 3

HAZ 2

BM 3

HAZ 2

HAZ 3

HAZ 2

HAZ 2

HAZ 3

BM 3

TORCHED CUTOUT

HAZ 3

HAZ 2

HAZ 2

BM 3

6

3

3

51

$$
6
$$

6

9

3

6

51

3

13

25

13

3

114

6

603

25
$3 \mathrm{~mm}$ from weld

Weld pass above fillet weld

$13 \mathrm{~mm}$ from weld

$3 \mathrm{~mm}$ from weld

$19 \mathrm{~mm}$ from weld

$6 \mathrm{~mm}$ from weld

$3 \mathrm{~mm}$ from weld
Along fusion line of fillet weld 
Table BIII, continued

\section{Location}

$\begin{array}{lllll}\text { Circumference } & \text { Base Metal, } & \text { Length } & \text { Indications } & \text { Comments } \\ \text { Weld, or HAZ } & \text { mm } & & \\ & \text { Number Course } & & \end{array}$

$5.70-5.75$

TORCHED CUTOUT

5.82

BM 2

13

2

$25 \mathrm{~mm}$ from weld

5.84-6.05 TORCHED CUTOUT

$6.07-6.12$

Weld

BM 3

BM 3

BM 3

BM 3

BM 3

BM 2

6.87

$7 \cdot 32-7 \cdot 67$

HAZ 2

$7 \cdot 34$

HAZ 3

$7 \cdot 37-7 \cdot 44$

HAZ 3

$7.44-7.54$

HAZ 2

$7.56-7.68$

7.66

$7.67-8.03$

7.73

7.87

7.90
HAZ 2

HAZ 3

BM 3

HAZ 3

HAZ 3

HAZ 2
6

13

9

9

6

3

13

356

25

70

102

127

3

356

1

13

13

3
$13 \mathrm{~mm}$ from weld

$13 \mathrm{~mm}$ from weld

$13 \mathrm{~mm}$ from weld

$6 \mathrm{~mm}$ from weld

$9 \mathrm{~mm}$ from weld

$6 \mathrm{~mm}$ from weld

Curvy

Along fusion line of fillet weld 
Location

\begin{tabular}{ll}
\hline Circumference & Base Metal, \\
m & Weld, or HAZ \\
& and Course
\end{tabular}

Number

$\begin{array}{llll}8.02 & \text { BM } 3 & 3 & 2 \\ 8.07 & \text { HAZ } 3 & 3 & 1 \\ 7.96 & \text { BM } 3 & & \end{array}$

$\begin{array}{llll}7.96 & \text { BM } 3 & & \\ 8.24 & \text { HAZ } 3 & 3 & 1 \\ 8.3 & \text { HAZ } 3 & 6 & 1 \\ 8.3 & \text { HAZ } 2 & 6 & 1\end{array}$

Vertical weld at $4.27 \mathrm{~m}$ in Course 3 :

6-mm indication on vertical weld fusion line, $133 \mathrm{~mm}$ from weld

$6-\mathrm{mm}$ indication on vertical weld fusion line, $210 \mathrm{~mm}$ from weld

Vertical welds $A, B$, and $C$ in Course 2 had no indications. 

APPENDIX C - ULTRASONIC INSPECTION FOR DELAMINATION

December 1985

Prepared by: Raymond E. Schramm

Fracture and Deformation Division

Institute for Materials Science and Engineering

National Bureau of Standards

Boulder, Colorado 80303 

The purpose of the ultrasonic inspection was to detect possible delaminations parallel to the top and bottom surfaces. The approach was to direct ultrasonic energy vertically into the steel plate. Echoes from the two outer surfaces occur at well defined times, and signals other than these indicate the presence of reflectors (flaws) at intermediate positions. This method is also frequently used for thickness measurements.

Commercially available equipment was used in a standard configuration. It consisted of a pulser to excite the ultrasonic transducer, a receiver operated in the pulse-echo mode to detect the signals, and an oscilloscope to display the output. The $12.7 \mathrm{~mm}(1.0 \mathrm{in.})$ diameter transducers were piezoelectric devices producing longitudinal waves at a resonant frequency of 5 or $10 \mathrm{MHz}$. The acoustic couplant necessary to transfer energy between the transducer and the steel plate was a mixture of petroleum jelly and mineral oil.

As a check on equipment and procedure, a reference plate about the same thickness as the tank was prepared from ferritic steel. It contained two machined slots that served as intermediate reflectors (Fig. C1). Measurements at three locations are shown in Figure C2. Each echo seen on the oscilloscope trace indicates a round trip through the thickness. Many more echoes occur but the time scale was set to see the detail on just the first few. A nominal handbook value of the sound velocity $(5.9 \mathrm{~km} / \mathrm{s}, 3.7 \mathrm{mi} . / \mathrm{s}$ ) was used to measure depth.

All measurements were made on the outside or convex surface of the tank. In most instances this meant going through a layer of paint. The only surface preparation was wire brushing by hand to remove any loose flakes. The paint did not present any obvious problems. The measurement procedure was to apply couplant, move the transducer and apply pressure to ensure good acoustic contact, observe the oscilloscope trace, and record the observation on a graph. 


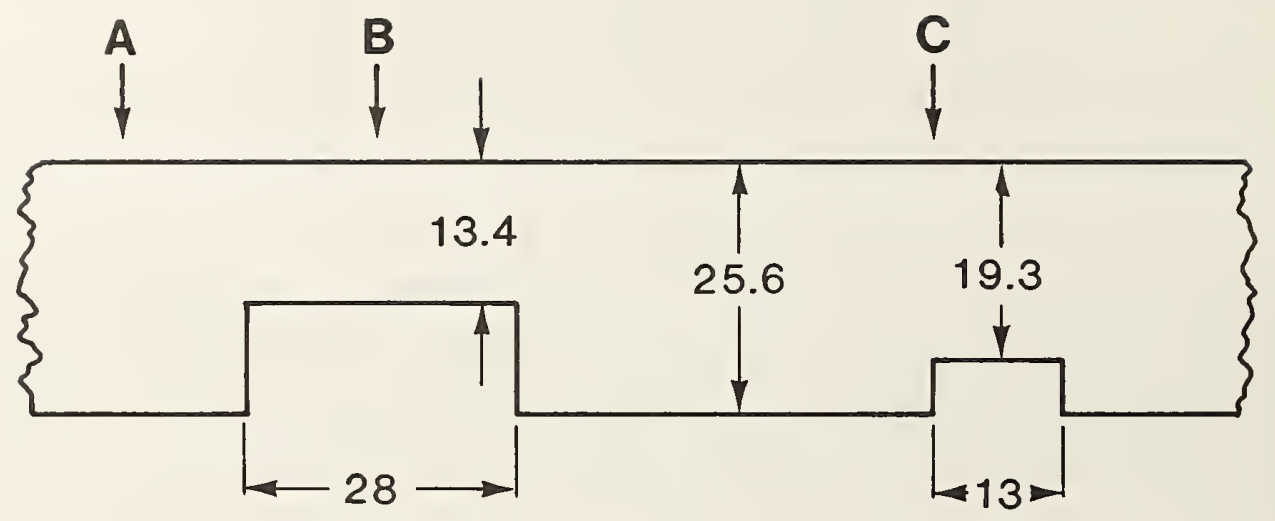

Figure C1. Ferritic steel plate with machined slots used for procedural check (side view, dimensions in $\mathrm{mm}$ ). A, B, and $\mathrm{C}$ indicate transducer positions for oscilloscope photographs in Figure C2. 


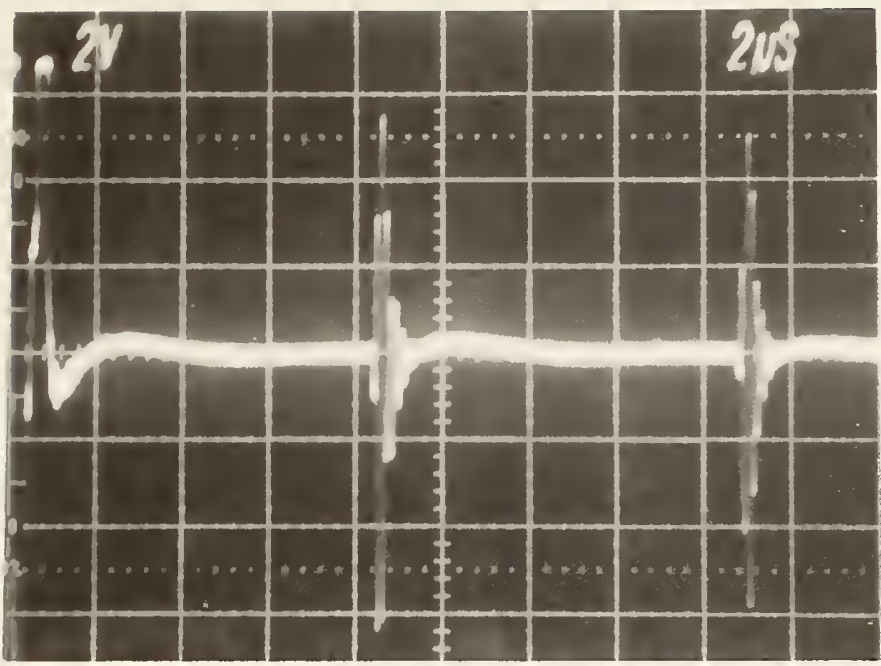

a

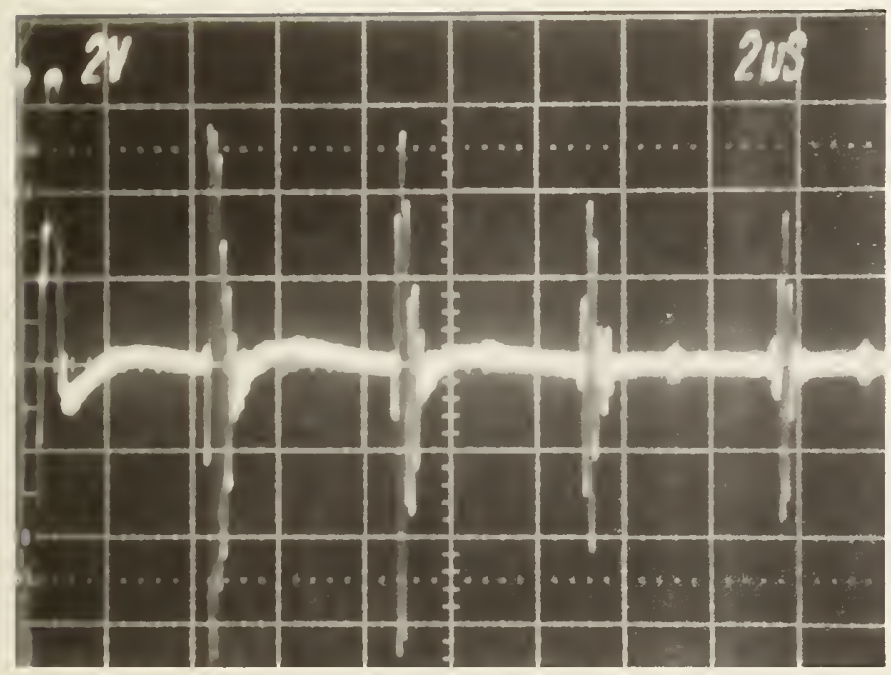

b

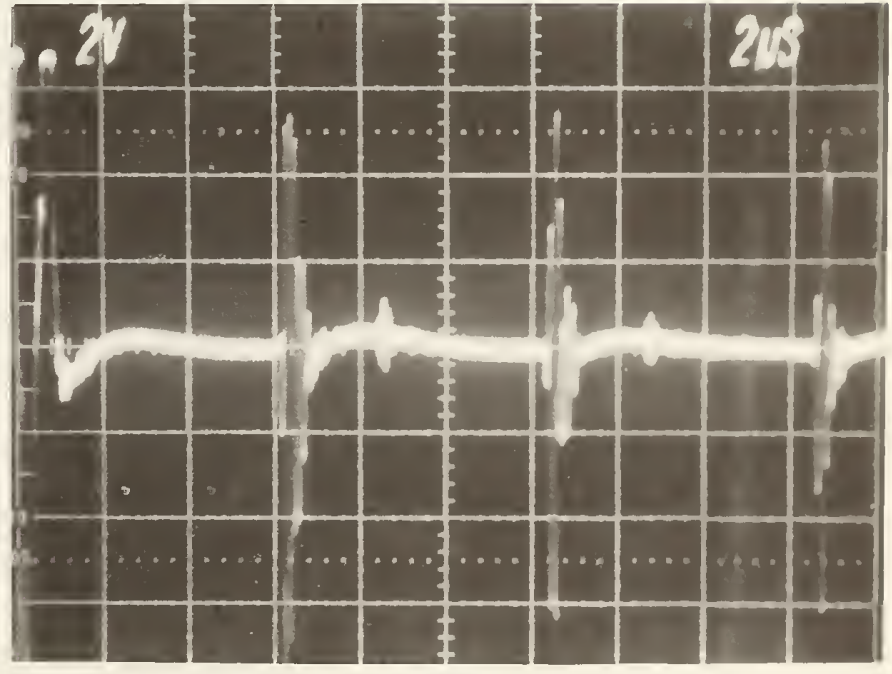

C

Figure C2. Oscilloscope photographs of measurements made on reference plate in Figure $\mathrm{C} 1$.

a) Transducer position A. Echoes at multiples of about $8.6 \mu$ s indicate a round trip distance of $50.8 \mathrm{~mm}(2.0 \mathrm{in.})$ or depth of $25.4 \mathrm{~mm}$ (1.0 in.).

b) Transducer position B. Echoes at multiples of about $4.4 \mu \mathrm{s}$ indicate a round trip distance of $26.0 \mathrm{~mm}(1.0 \mathrm{in.})$ or depth of $13.0 \mathrm{~mm}(0.51 \mathrm{in.})$.

c) Transducer position C. Echoes at multiples of about 6.4 and $8.6 \mu \mathrm{s}$ indicate round trip distances of $37.8 \mathrm{~mm}(1.5 \mathrm{in.})$ and $50.8 \mathrm{~mm}(2.0 \mathrm{in.})$ or depths of $18.9(0.74 \mathrm{in.})$ and $25.4 \mathrm{~mm}(1.0 \mathrm{in.})$. The transducer straddles the edge of the slot here. 
The information from the oscilloscope trace of the ultrasonic signal

fell into two basic categories:

1. The presence of echoes from the outside surfaces

2. Other signals occurring at an earlier time, indicating the presence of reflectors in the interior of the plate

These observations were divided into five signal levels. Degrees 1 and 2 represent what would be expected of material with through-depth integrity. Degree 3 is the result of conditions likely to precede delamination, whereas degrees 4 and 5 are the consequences of laminar separation. The five graphical symbols used and the ir meanings are given in Table CI. The photographs in Figure C3 are examples of signal appearance. Figure C3a shows a very clean baseline with strong signals indicating first and second echoes from the inside surface (noted by markers). In Figure C3b the baseline displays some small noise, but the only strong signals are again from the inside surface. In contrast, $\mathrm{F}$ igure $\mathrm{C} 3 \mathrm{c}$ indicates strong reflections from intermediate depths through the wall thickness; since the inside-surface reflections are still present, the delaminations causing the intermediate echoes are probably tightly closed. Figure C3d shows only signals from intermediate depths and none from the inside wall; here the delaminations appear to have opened up so that ultrasonic waves did pass through them.

Initial inspections ( $10 \mathrm{MHz}$ transducer) were made of three plates cut from the tank sections:

Specimen 1 - Ring 1, Course 1, 3.91-4.70 m, $0.3 \mathrm{~m}$ (12 in.) high (contains a vertical weld)

Specimen 2 - Ring 3, Courses 2 and 3,2.06-2.73 m, 0.25 $\mathrm{m}$ (10 in.) above and below the weld joining the two courses

Specimen 3 - Ring 3, Courses 2 and 3, 1.42-1.88 m, $0.28 \mathrm{~m}$ (11 in.) above and $0.23 \mathrm{~m}$ (9 in.) below the weld joining the two courses.

Measurements over the entire area of these specimens were done on a $2.54 \mathrm{~cm}$ ( 1.0 in.) grid. Owing to surface roughness, there were some locations where it was not possible to obtain good acoustic coupling (especially near the welds), and no observations were recorded. 
Table CI. Graphical symbols used for ultrasonic measurements

\begin{tabular}{|c|c|c|}
\hline Degree & Symbol & Explanation \\
\hline 1 & 0 & $\begin{array}{l}\text { Clean baseline between outer-surface echoes } \\
\text { indicates homogeneous plate. }\end{array}$ \\
\hline 2 & Q & $\begin{array}{l}\text { Slight noise on baseline between strong } \\
\text { outer-surface echoes - indicates small amount } \\
\text { discontinuity through plate thickness. }\end{array}$ \\
\hline 3 & $\otimes$ & $\begin{array}{l}\text { Moderate noise on baseline between strong } \\
\text { outer-surface echoes - indicates increasing } \\
\text { amount of discontinuities. }\end{array}$ \\
\hline 4 & $\ominus$ & $\begin{array}{l}\text { Well-defined intermediate return(s) with } \\
\text { moderate-to-strong outer-surface echoes - } \\
\text { indicates likely delamination that is still } \\
\text { tight enough to transmit sound. }\end{array}$ \\
\hline 5 & & $\begin{array}{l}\text { Strong intermediate return(s) with no } \\
\text { outer-surface echoes - indicates complete } \\
\text { discontinuity due to delamination. }\end{array}$ \\
\hline
\end{tabular}

NOTE: See Figure C3 for examples of oscilloscope traces. 


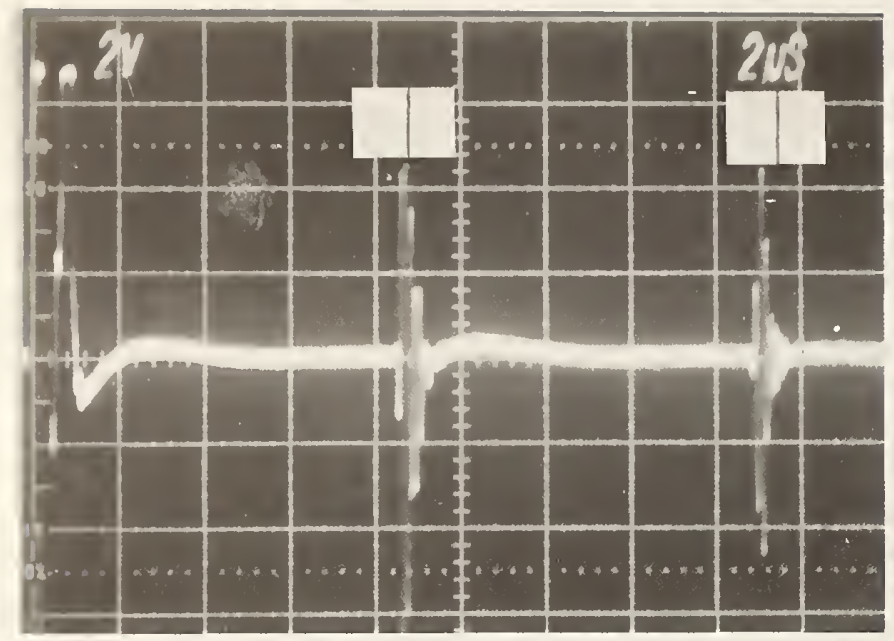

a $\bigcirc$

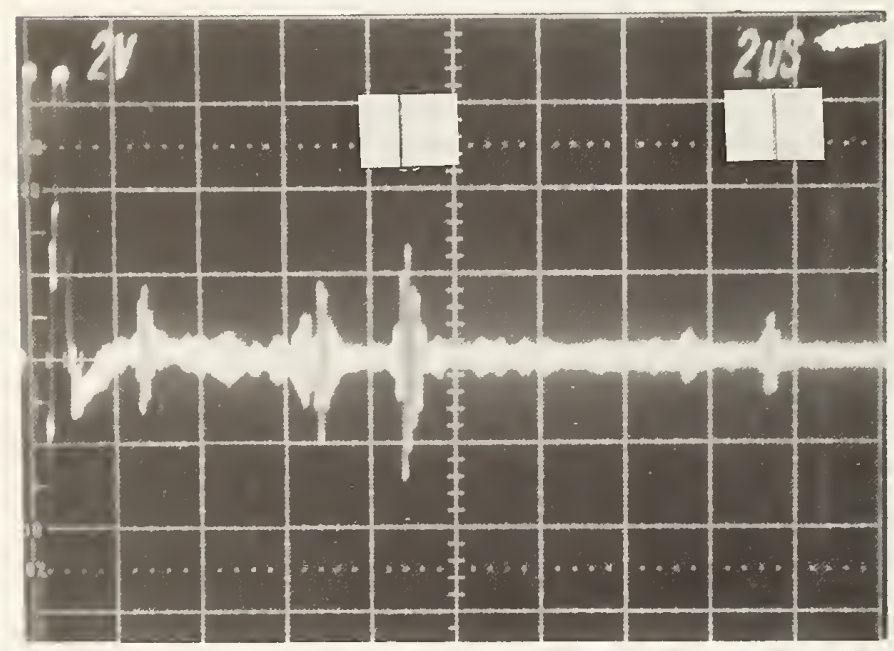

c $\theta$

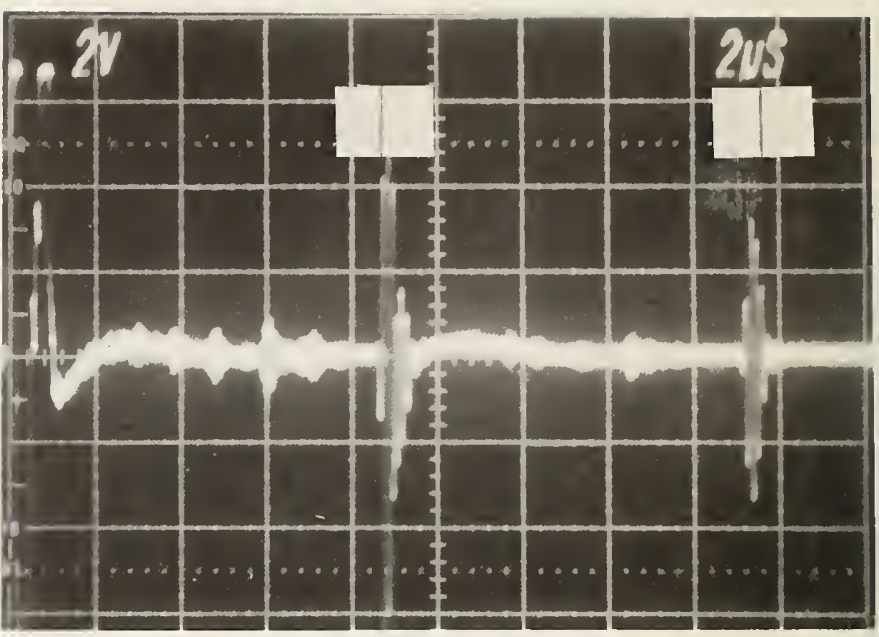

b 0

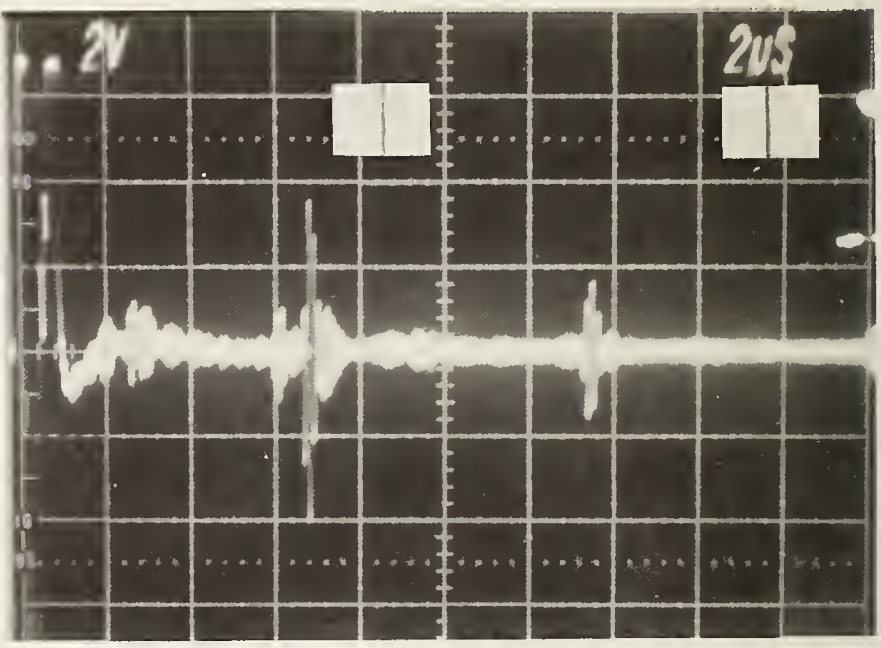

d

Figure C3. Samples of typical oscilloscope traces. Markers near top of each photo indicate position of first two echoes from outer surfaces. Refer to Table CI. $x$-axis: $2 \mathrm{~V} / \mathrm{d}$ ivision; $\mathrm{y}$-axis: $2 \mu \mathrm{s} / \mathrm{d}$ ivision.

a) Degree 1. Specimen $2[2.11 \mathrm{~m}$ on circumference, $0.05 \mathrm{~m}$ (2 in.) below weld].

b) Degree 2. Specimen $2[2.11 \mathrm{~m}$ on circumference, $0.20 \mathrm{~m}$ (7.9 in.) above we ld].

c) Degree 4. Specimen $1[4.24 \mathrm{~m}$ on circumference, $0.20 \mathrm{~m}(7.9 \mathrm{in.})$ above bottom of plate].

d) Degree 5. Specimen $1[4.29 \mathrm{~m}$ on circumference, $0.20 \mathrm{~m}(7.9 \mathrm{in}$.$) above$ bottom of plate]. 
The results in Figures $\mathrm{C} 4$ through $\mathrm{C} 6$ indicate that major problems with delamination were found only in Specimen 1 (Course 1); large areas on both sides of the vertical weld produced intermediate returns of the ultrasonic signal, indicating material separation through the depth (degrees 4 and 5) as well as the moderate baseline noise from discontinuities that can precede actual separation (degree 3 ). Specimen 2 appeared quite sound (degrees 1 and 2) as did Specimen 3 where only one small area gave degree 3 signals. The arrows in Figures $\mathrm{C} 4$ and $\mathrm{C} 5$ indicate the locations corresponding to the oscilloscope traces in Figure $\mathrm{C3}$.

A second inspection (with the $5 \mathrm{MHz}$ transducer) was a survey around the entire tank circumference in both Rings 1 and 2 . In Ring 1 , measurements were made at 2.5 and $7.6 \mathrm{~cm}$ ( 1 and $3 \mathrm{in.}$ ) below the fracture surface at $5.1 \mathrm{~cm}$ (2 in.) intervals around the circumference; additional measurements were taken at $33.0 \mathrm{~cm}$ (13 in.) below the fracture at $30.5 \mathrm{~cm}$ (12 in.) intervals. In Ring 2, measurements were made at 5.1 and $10.2 \mathrm{~cm}$ (2 and 4 in.) above the fracture surface at $30.5 \mathrm{~cm}$ (12 in.) intervals. The survey results are in Figure C7. The area immediately above the fracture in Ring 2 showed only a few spots of returning degree 3 signals (moderate baseline noise); from the degree 1 and 2 ultrasonic echo returns; from the degree 1 and 2 ultrasonic echo returns, nearly all areas of the material appeared to be sound. However, below the fracture in Ring 1, there was a considerable mixture of areas, some showing considerable delamination (degrees 4 and 5 ) while others were normal. Specimen 1 (Eig. C4), also from Ring 1, showed much damage. 


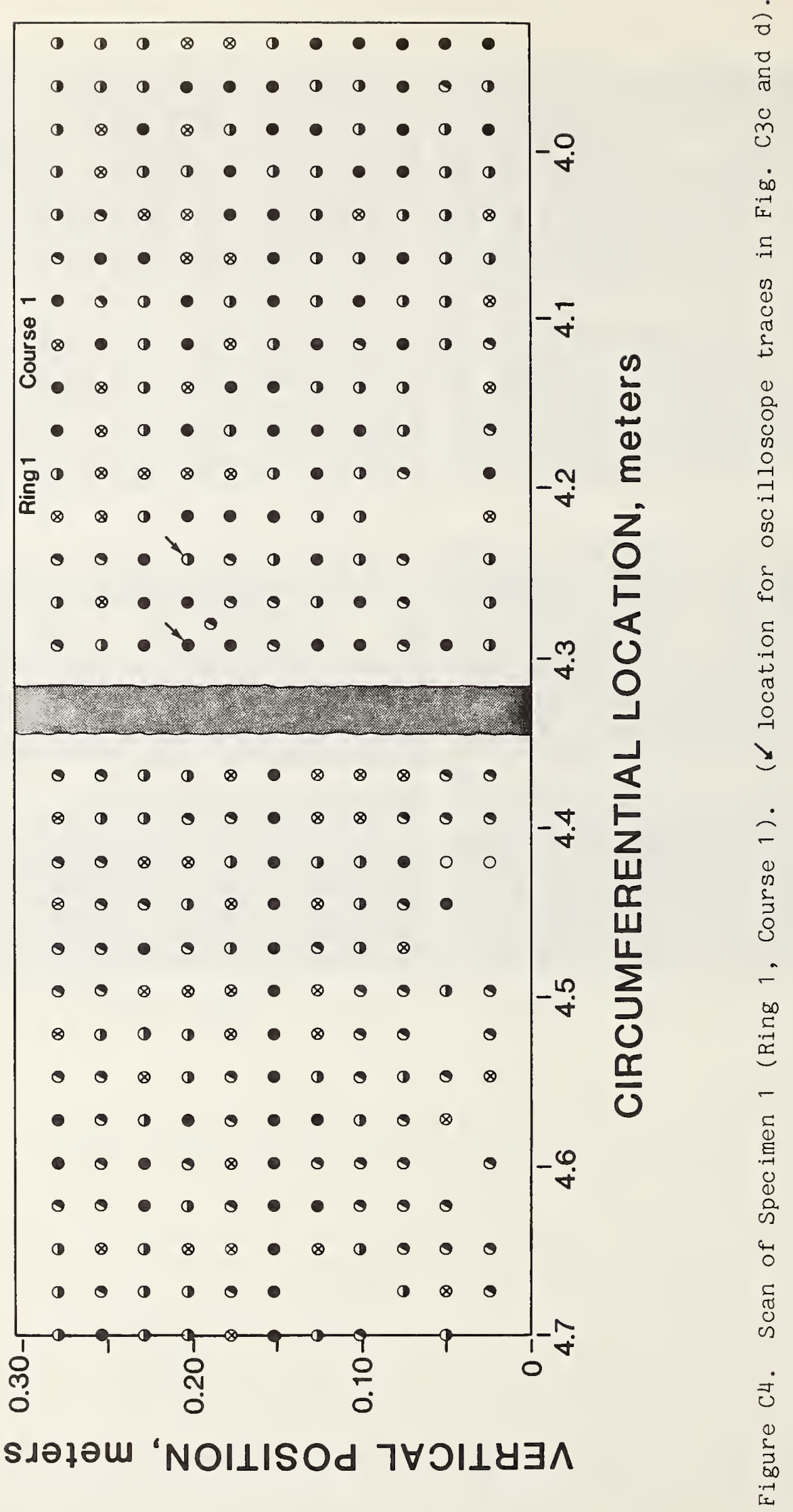




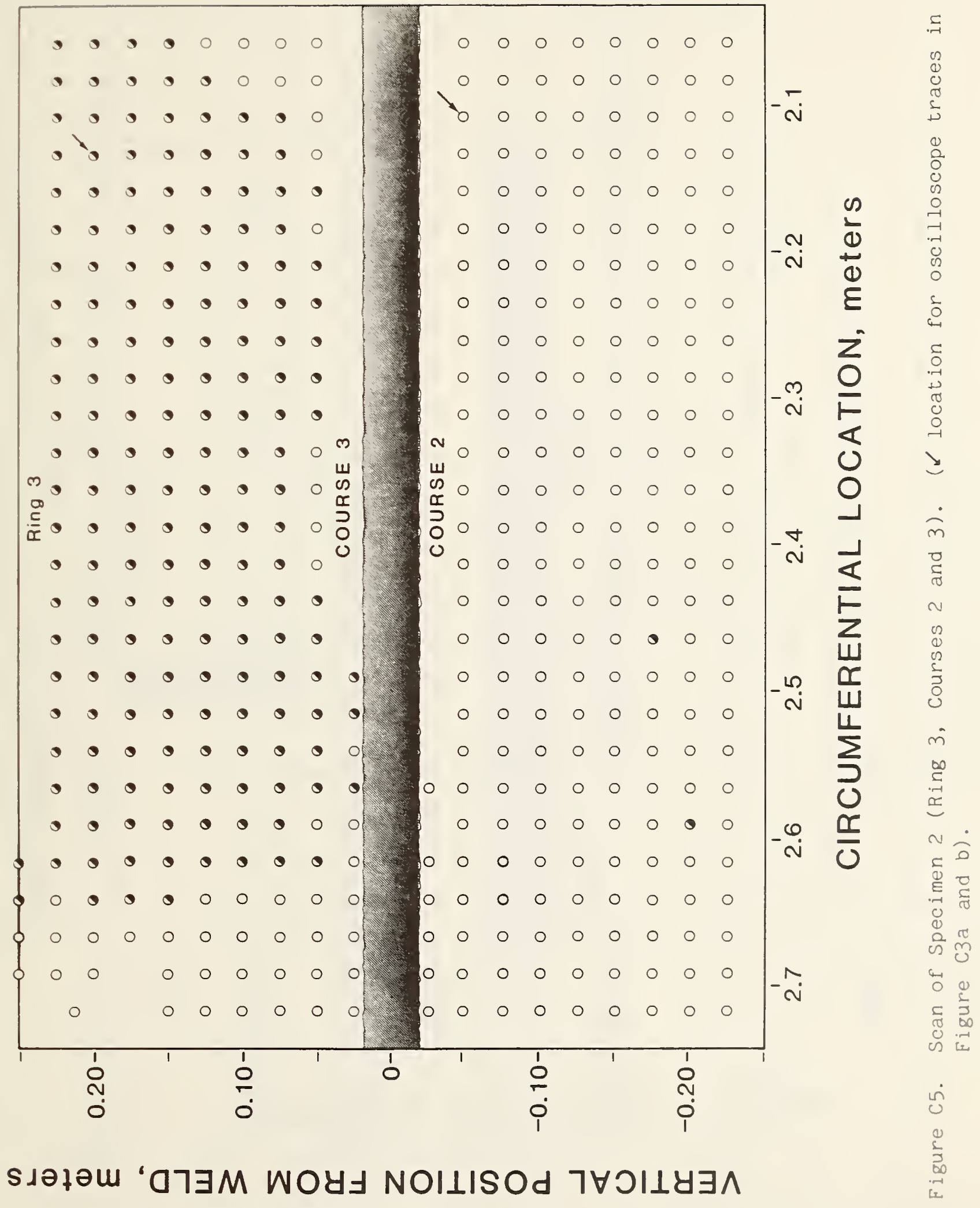




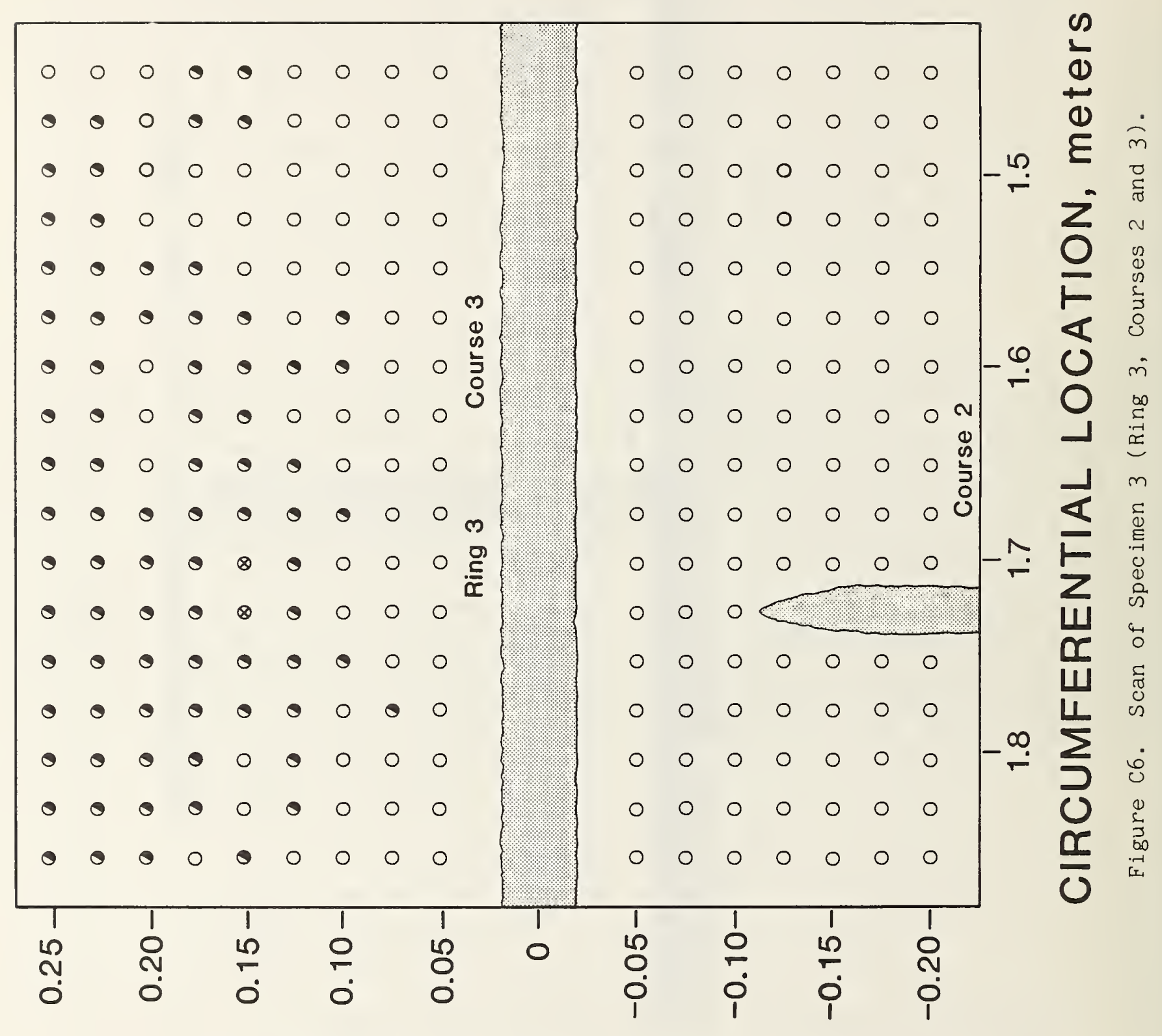

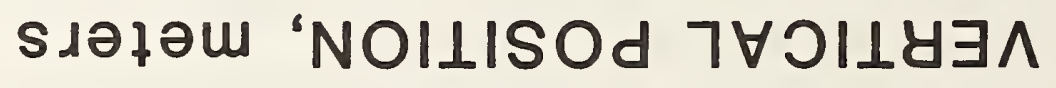




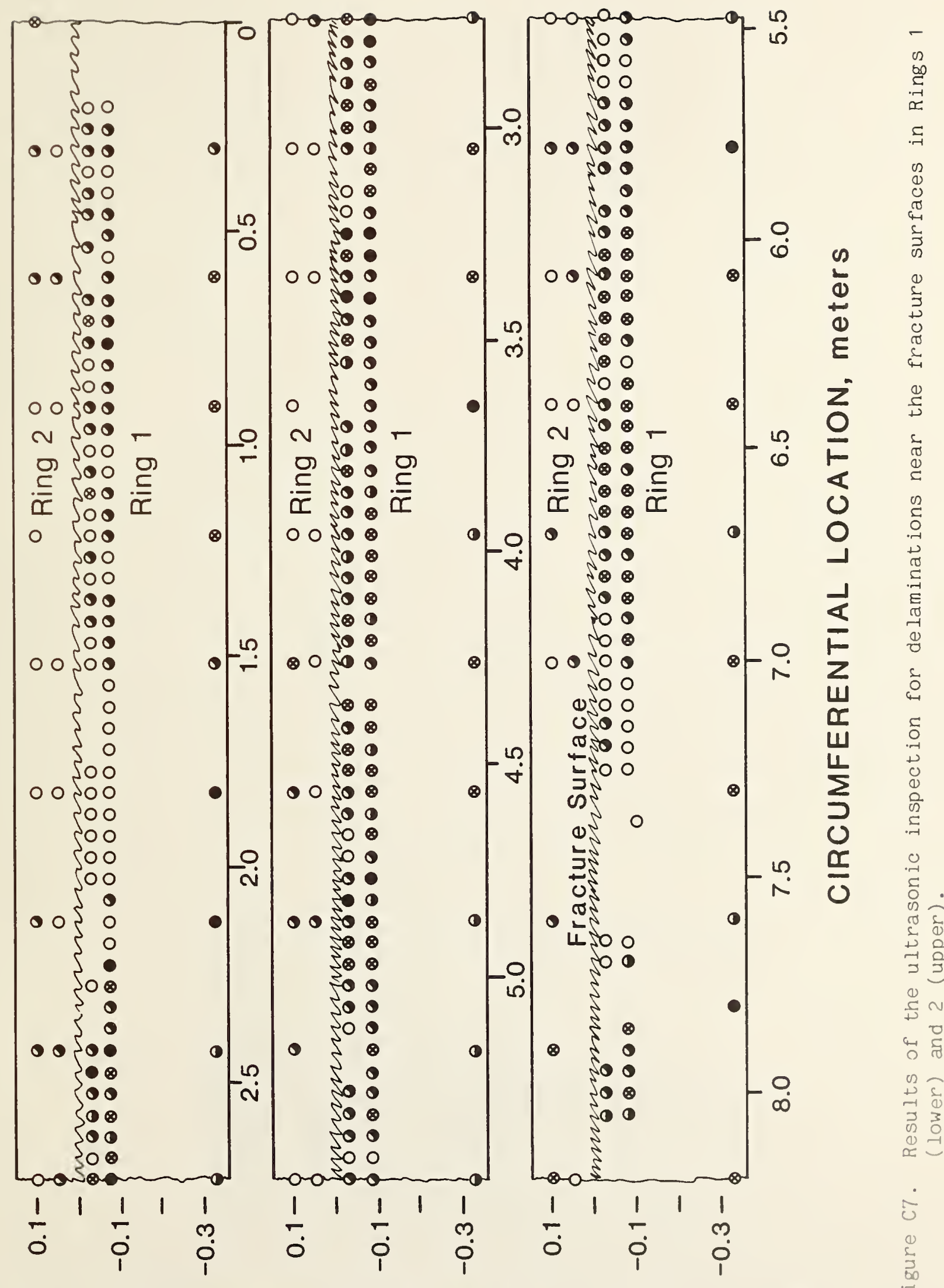

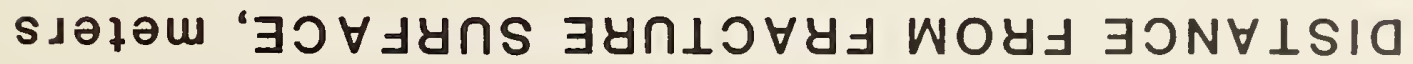



APPENDIX D - ROCKWELL HARDNESS

December 1985

Prepared by: Patrick T. Purtscher

Fracture and Deformation Division

Institute for Materials Science and Engineering

National Bureau of Standards

Boulder, Colorado 80303 



$\begin{array}{lll}\text { Base Metal } & 1 & 50.5 \\ \text { C1 } & 2 & 51.5 \\ & 3 & 51.5 \\ & 4 & 51.0 \\ \text { HAZ } & & \\ \text { C1 } & 5 & 52 \\ & 6 & 54.5 \\ \text { Weld Metal } & & \\ & 7 & 54 \\ & 8 & 52.5 \\ \text { HAZ } & 9 & 52.5 \\ \text { C2 } & & \\ & 10 & 54 \\ \text { Base Metal } & 11 & 51.5 \\ \text { C2 } & & \\ & 12 & 50.5 \\ & 13 & 50 \\ & 14 & 50.5\end{array}$

Identification numbers refer to the indentations, from left to right, in the photographs.

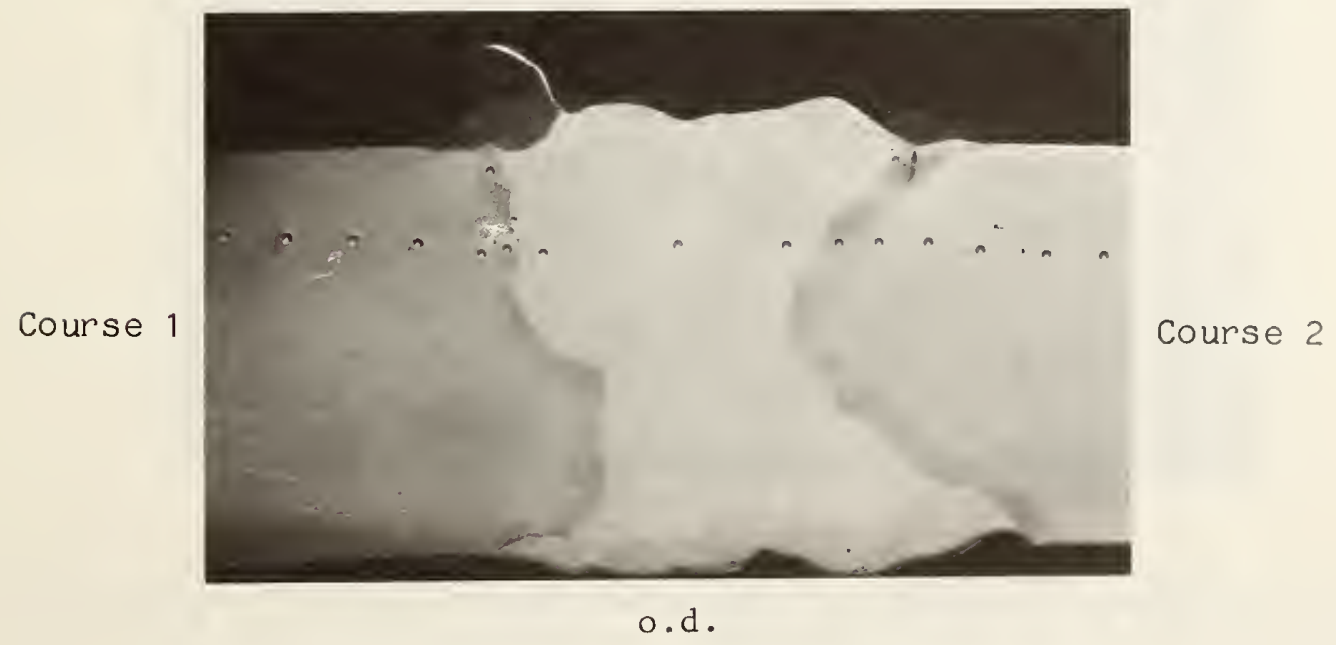

Eigure D1. Hardness traverses of the weld between Course 1 and Course 2 . 


\begin{tabular}{|c|c|c|c|c|}
\hline & \multicolumn{2}{|c|}{ Traverse 1} & \multicolumn{2}{|c|}{ Traverse 2} \\
\hline & $\begin{array}{l}\text { Ident if ication } \\
\text { Number }\end{array}$ & $\begin{array}{l}\text { Hardness, } \\
\text { HRA } \\
\end{array}$ & $\begin{array}{l}\text { Identification } \\
\text { Number }\end{array}$ & $\begin{array}{l}\text { Hardness, } \\
\text { HRB } \\
\end{array}$ \\
\hline $\begin{array}{l}\text { Base Metal } \\
\text { C2 }\end{array}$ & $\begin{array}{l}1 \\
2 \\
3\end{array}$ & $\begin{array}{l}51.5 \\
53.5 \\
54\end{array}$ & $\begin{array}{l}1 \\
2\end{array}$ & $\begin{array}{l}88 \\
90.5\end{array}$ \\
\hline $\begin{array}{l}\mathrm{HAZ} \\
\mathrm{C} 2\end{array}$ & $\begin{array}{l}4 \\
5\end{array}$ & $\begin{array}{l}55 \\
57.5\end{array}$ & 3 & 104.5 \\
\hline Weld Metal & $\begin{array}{r}6 \\
7 \\
8 \\
9 \\
10 \\
11 \\
12\end{array}$ & $\begin{array}{l}56.5 \\
55.5 \\
56 \\
55.5 \\
55.5 \\
55.5 \\
57\end{array}$ & $\begin{array}{r}4 \\
5 \\
6 \\
7 \\
8 \\
9 \\
10\end{array}$ & $\begin{array}{l}98 \\
94.5 \\
95.5 \\
96 \\
95 \\
95.5 \\
94.5\end{array}$ \\
\hline $\begin{array}{l}\mathrm{HAZ} \\
\mathrm{C} 3\end{array}$ & $\begin{array}{l}13 \\
14\end{array}$ & $\begin{array}{l}57 \cdot 5 \\
55 \cdot 5\end{array}$ & $\begin{array}{l}11 \\
12\end{array}$ & $\begin{array}{l}106 \\
95.5\end{array}$ \\
\hline $\begin{array}{l}\text { Base Metal } \\
\text { C3 }\end{array}$ & $\begin{array}{l}15 \\
16 \\
17\end{array}$ & $\begin{array}{l}54 \\
54 \\
53.5\end{array}$ & 13 & 94 \\
\hline
\end{tabular}

Traverse 2

Traverse 1

Course 2

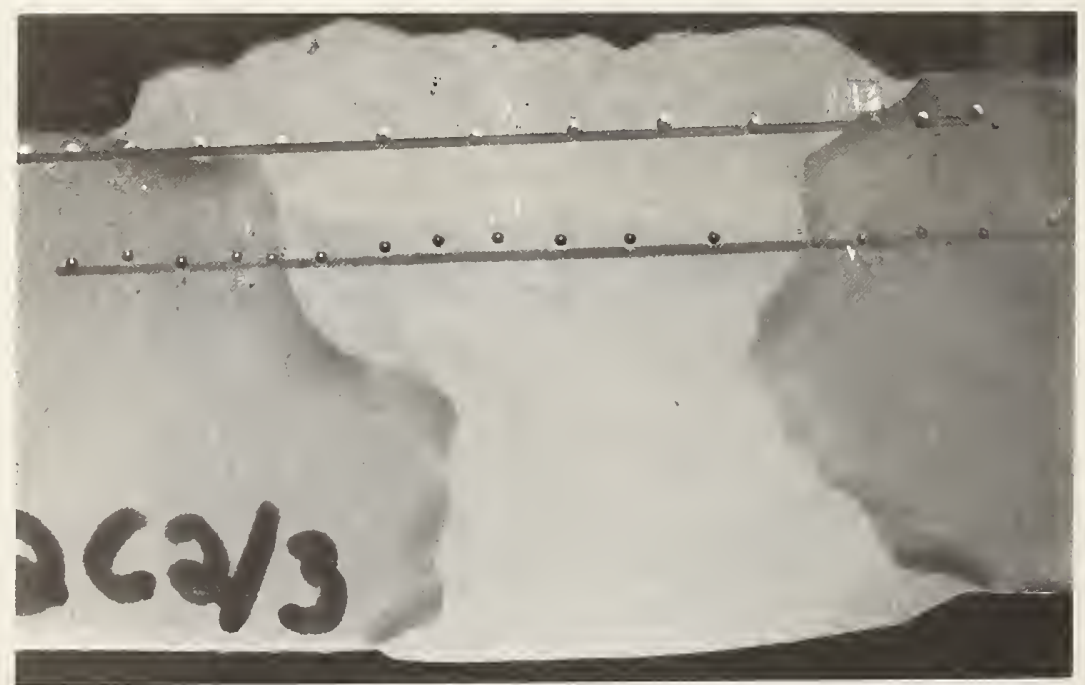

Course 3

o.d.

Figure D2. Hardness traverses of the weld between Course 2 and Course 3 . 


\begin{tabular}{|c|c|c|c|c|}
\hline & \multicolumn{2}{|c|}{ Traverse 1} & \multicolumn{2}{|c|}{ Traverse 2} \\
\hline & $\begin{array}{l}\text { Ident ification } \\
\text { Number }\end{array}$ & $\begin{array}{l}\text { Hardness, } \\
\text { HRA } \\
\end{array}$ & $\begin{array}{l}\text { Identification } \\
\text { Number }\end{array}$ & $\begin{array}{l}\text { Hardness, } \\
\text { HRA } \\
\end{array}$ \\
\hline $\begin{array}{l}\text { Base Metal } \\
\text { C3 }\end{array}$ & $\begin{array}{l}1 \\
2\end{array}$ & $\begin{array}{l}50.5 \\
51.5\end{array}$ & $\begin{array}{l}1 \\
2\end{array}$ & $\begin{array}{l}52 \\
52.5\end{array}$ \\
\hline $\begin{array}{l}\mathrm{HAZ} \\
\mathrm{C} 3\end{array}$ & $\begin{array}{l}3 \\
4 \\
5\end{array}$ & $\begin{array}{l}51.5 \\
51.5 \\
52\end{array}$ & $\begin{array}{l}3 \\
4\end{array}$ & $\begin{array}{l}52 \cdot 5 \\
53\end{array}$ \\
\hline Weld Metal & $\begin{array}{r}6 \\
7 \\
8 \\
9 \\
10 \\
11\end{array}$ & $\begin{array}{l}52.5 \\
53.5 \\
53.5 \\
53.5 \\
53.5 \\
52.5\end{array}$ & $\begin{array}{l}5 \\
6 \\
7 \\
8 \\
9\end{array}$ & $\begin{array}{l}53 \\
53.5 \\
54 \\
54 \\
54.5\end{array}$ \\
\hline $\begin{array}{l}\mathrm{HAZ} \\
\mathrm{C} 4\end{array}$ & $\begin{array}{l}12 \\
13 \\
14\end{array}$ & $\begin{array}{l}54 \cdot 5 \\
52 \\
52\end{array}$ & $\begin{array}{l}10 \\
11\end{array}$ & $\begin{array}{l}53.5 \\
52.5\end{array}$ \\
\hline $\begin{array}{l}\text { Base Metal } \\
\text { C4 }\end{array}$ & $\begin{array}{l}15 \\
16\end{array}$ & $\begin{array}{l}51 \cdot 5 \\
52\end{array}$ & $\begin{array}{l}12 \\
13 \\
14\end{array}$ & $\begin{array}{l}52.5 \\
52.5 \\
86 \text { HRB }\end{array}$ \\
\hline
\end{tabular}

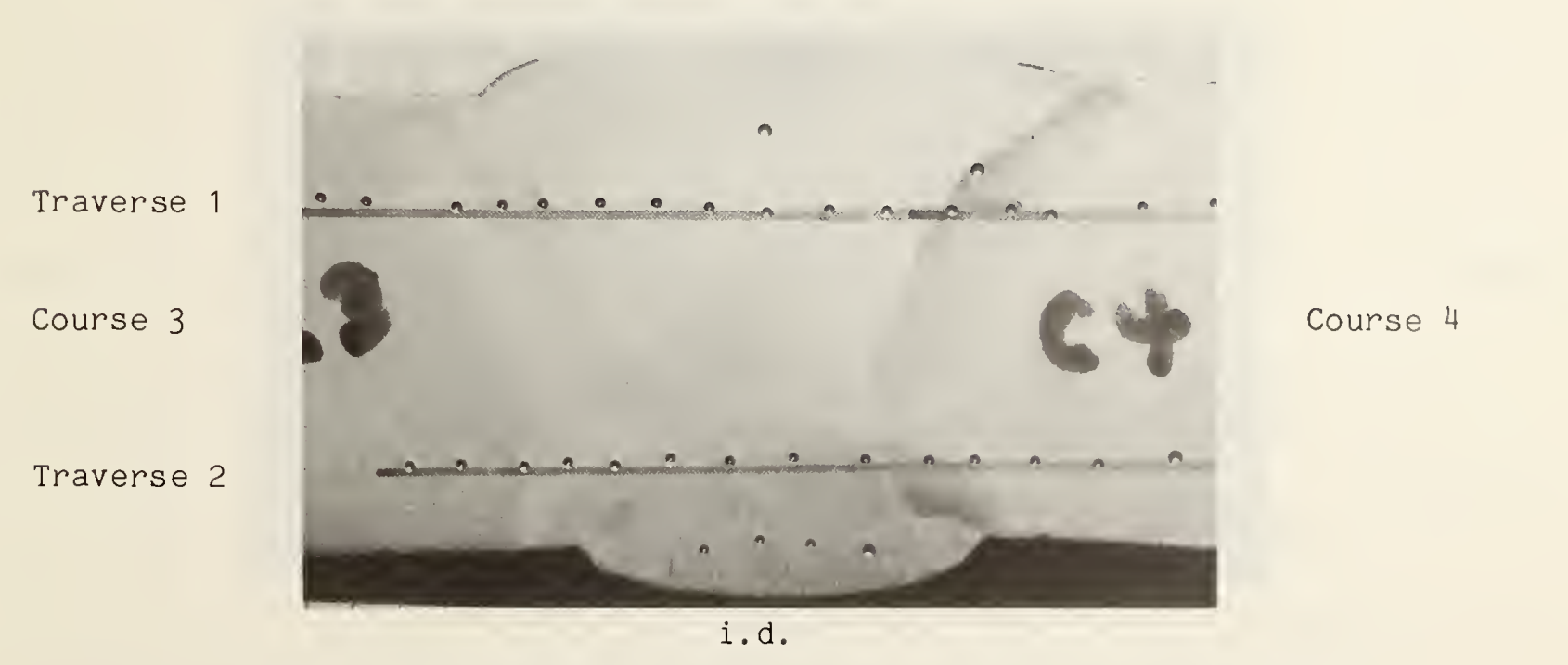

Figure D3. Hardness traverses of the weld between Course 3 and course 4. 


\begin{tabular}{|c|c|c|c|c|}
\hline & \multicolumn{2}{|c|}{ Traverse 1} & \multicolumn{2}{|c|}{ Traverse 2} \\
\hline & $\begin{array}{l}\text { Ident if ication } \\
\text { Number }\end{array}$ & $\begin{array}{l}\text { Hardness, } \\
\text { HRA } \\
\end{array}$ & $\begin{array}{l}\text { Identification } \\
\text { Number }\end{array}$ & $\begin{array}{l}\text { Hardness, } \\
\text { HRA } \\
\end{array}$ \\
\hline $\begin{array}{l}\text { Base Metal } \\
\text { C5 }\end{array}$ & $\begin{array}{l}1 \\
2 \\
3\end{array}$ & $\begin{array}{l}52.5 \\
53.5 \\
53.5\end{array}$ & $\begin{array}{l}1 \\
2 \\
3\end{array}$ & $\begin{array}{l}52.5 \\
53.5 \\
54.5\end{array}$ \\
\hline $\begin{array}{l}\mathrm{HAZ} \\
\mathrm{C} 5\end{array}$ & $\begin{array}{l}4 \\
5\end{array}$ & $\begin{array}{l}54 \cdot 5 \\
55\end{array}$ & $\begin{array}{l}4 \\
5 \\
6\end{array}$ & $\begin{array}{l}55.5 \\
55.5 \\
57.5\end{array}$ \\
\hline Weld Metal & $\begin{array}{r}6 \\
7 \\
8 \\
9 \\
10\end{array}$ & $\begin{array}{l}51 \\
51.5 \\
53 \cdot 5 \\
50.5 \\
48\end{array}$ & $\begin{array}{r}7 \\
8 \\
9 \\
10\end{array}$ & $\begin{array}{l}57.5 \\
58 \\
58 \\
57.5\end{array}$ \\
\hline $\begin{array}{l}\mathrm{HAZ} \\
\mathrm{C} 4\end{array}$ & $\begin{array}{l}11 \\
12\end{array}$ & $\begin{array}{l}57 \\
54.5\end{array}$ & $\begin{array}{l}11 \\
12 \\
13\end{array}$ & $\begin{array}{l}57 \\
57.5 \\
56.5\end{array}$ \\
\hline $\begin{array}{l}\text { Base Metal } \\
\text { C4 }\end{array}$ & $\begin{array}{l}13 \\
14 \\
15\end{array}$ & $\begin{array}{l}54 \\
54.5 \\
53.5\end{array}$ & $\begin{array}{l}14 \\
15\end{array}$ & $\begin{array}{l}54.5 \\
53.5\end{array}$ \\
\hline Traverse 1 & 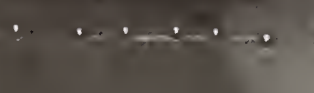 & & $\therefore$. & $o . d$. \\
\hline Course 5 & $0^{\circ}$ & & & Course 4 \\
\hline Traverse 2 & & & $\therefore \quad$ & i.d. \\
\hline
\end{tabular}

Figure D4. Hardness traverses of the weld between Course 4 and Course 5 . 


\section{Traverse 1}

Identification Hardness, Number

$\begin{array}{ll}\text { Base Metal } & 1 \\ & 2 \\ & 3 \\ 4\end{array}$

HAZ

Weld Metal

HAZ

Base Metal

11

12

13

14

15
HRA

50.5

50.5

51

50.5

52

54

53

52

51.5

53

54.5

53.5

51

51

50.5
Traverse 2

Identification

Number

Hardness, HRB

85.5

85.5

86.5

87.5

86.5

91.5

88.5

88.5

86.5

87.5

90

90

86.5

13

14

85.5

15

Traverse 1

Traverse 2

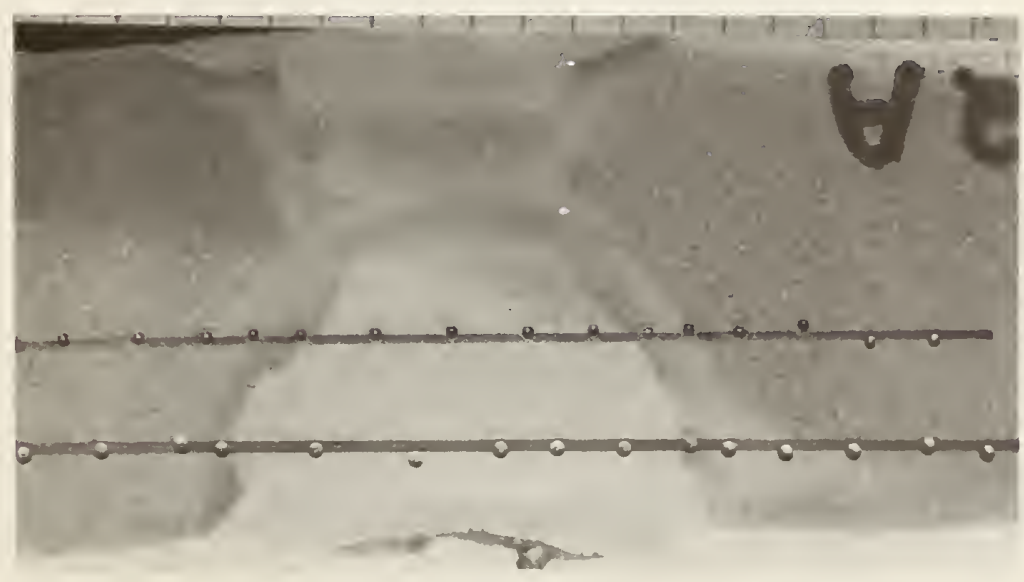

i.d.

Figure D5. Hardness traverses across vertical weld A in Course 2. 


\begin{tabular}{|c|c|c|c|c|}
\hline & \multicolumn{2}{|c|}{ Traverse 1} & \multicolumn{2}{|c|}{ Traverse 2} \\
\hline & $\begin{array}{l}\text { Ident if ication } \\
\text { Number }\end{array}$ & $\begin{array}{l}\text { Hardness, } \\
\text { HRA }\end{array}$ & $\begin{array}{l}\text { Identification } \\
\text { Number }\end{array}$ & $\begin{array}{l}\text { Hardness, } \\
\text { HRA }\end{array}$ \\
\hline Base Metal & $\begin{array}{l}1 \\
2 \\
3\end{array}$ & $\begin{array}{l}51.5 \\
52 \\
51.5\end{array}$ & $\begin{array}{l}1 \\
2 \\
3 \\
4 \\
5\end{array}$ & $\begin{array}{l}52 \\
52 \\
52.5 \\
51.5 \\
50.5\end{array}$ \\
\hline $\mathrm{HAZ}$ & $\begin{array}{l}4 \\
5 \\
6 \\
7\end{array}$ & $\begin{array}{l}50.5 \\
50.5 \\
53 \\
53\end{array}$ & $\begin{array}{l}6 \\
7 \\
8\end{array}$ & $\begin{array}{l}51 \\
52 \\
53\end{array}$ \\
\hline Weld Metal & $\begin{array}{r}8 \\
9 \\
10\end{array}$ & $\begin{array}{l}51.5 \\
51.5 \\
51.5\end{array}$ & $\begin{array}{r}9 \\
10 \\
11\end{array}$ & $\begin{array}{l}51 \\
52 \\
51.5\end{array}$ \\
\hline HAZ & $\begin{array}{l}11 \\
12 \\
13\end{array}$ & $\begin{array}{l}52 \\
52 \\
51\end{array}$ & $\begin{array}{l}12 \\
13 \\
14\end{array}$ & $\begin{array}{l}53 \\
52.5 \\
50.5\end{array}$ \\
\hline Base Metal & $\begin{array}{l}14 \\
15\end{array}$ & $\begin{array}{l}51.5 \\
51.5\end{array}$ & $\begin{array}{l}15 \\
16 \\
17\end{array}$ & $\begin{array}{l}51 \\
51 \\
51\end{array}$ \\
\hline
\end{tabular}

Traverse 1

Traverse 2
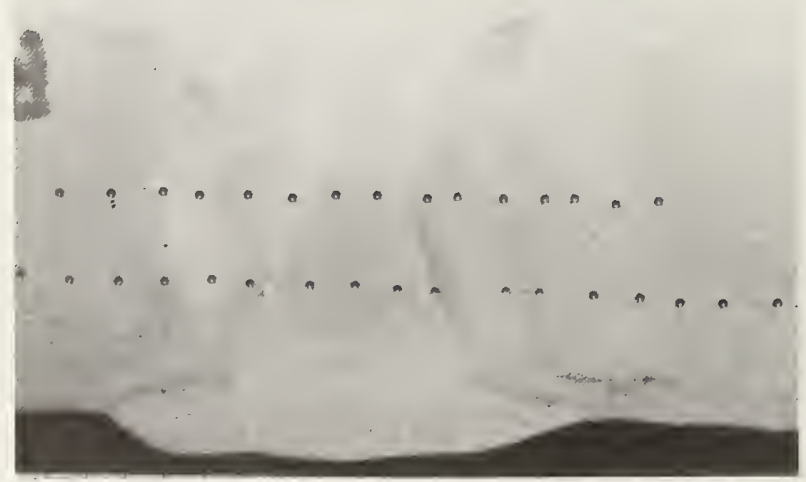

i.d.

Figure D6. Hardness traverses across vertical weld B in Course 2. 


\begin{tabular}{|c|c|c|c|c|c|}
\hline & & \multicolumn{2}{|c|}{ Traverse 1} & \multicolumn{2}{|c|}{ Traverse 2} \\
\hline & & $\begin{array}{l}\text { Identification } \\
\text { Number }\end{array}$ & $\begin{array}{l}\text { Hardness, } \\
\text { HRA } \\
\end{array}$ & $\begin{array}{l}\text { Identification } \\
\text { Number }\end{array}$ & $\begin{array}{l}\text { Hardness, } \\
\text { HRA }\end{array}$ \\
\hline Base & Metal & $\begin{array}{l}1 \\
2 \\
3\end{array}$ & $\begin{array}{l}49.5 \\
49.5 \\
49.5\end{array}$ & $\begin{array}{l}1 \\
2\end{array}$ & $\begin{array}{l}86.5 \\
86.5\end{array}$ \\
\hline HAZ & & $\begin{array}{l}4 \\
5\end{array}$ & $\begin{array}{l}51.5 \\
53.5\end{array}$ & $\begin{array}{l}3 \\
4\end{array}$ & $\begin{array}{l}86.5 \\
89.5\end{array}$ \\
\hline Weld & Metal & $\begin{array}{l}6 \\
7 \\
8 \\
9 \\
9\end{array}$ & $\begin{array}{l}50.5 \\
50.5 \\
50.5 \\
51.5 \\
91.5\end{array}$ & $\begin{array}{l}5 \\
6 \\
7 \\
8\end{array}$ & $\begin{array}{l}88 \\
90 \\
89.5 \\
90\end{array}$ \\
\hline HAZ & & $\begin{array}{l}10 \\
11\end{array}$ & $\begin{array}{l}53 \\
53\end{array}$ & $\begin{array}{l}10 \\
11\end{array}$ & $\begin{array}{l}89 \\
86\end{array}$ \\
\hline Base & Metal & $\begin{array}{l}12 \\
13 \\
14\end{array}$ & $\begin{array}{l}50.5 \\
50.5 \\
51\end{array}$ & $\begin{array}{l}12 \\
13\end{array}$ & $\begin{array}{l}87 \\
87\end{array}$ \\
\hline
\end{tabular}

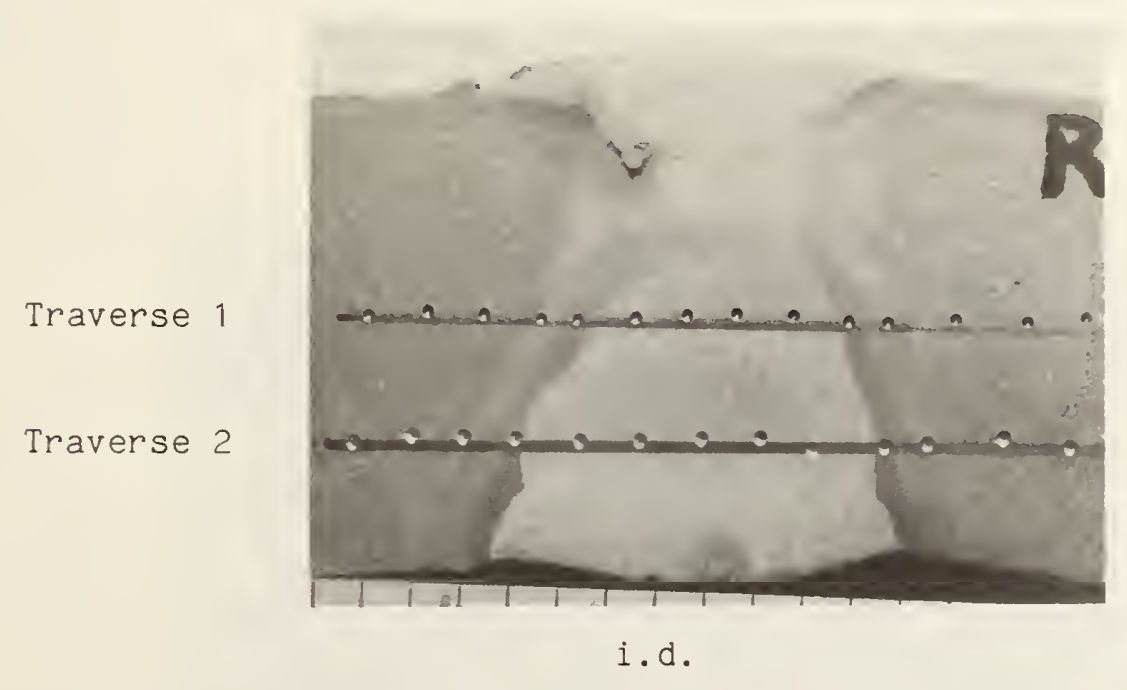

Figure D7. Hardness traverses across vertical weld C in Course 2. 


\begin{tabular}{|c|c|c|c|c|c|c|}
\hline & \multicolumn{2}{|c|}{ Traverse 1} & \multicolumn{2}{|c|}{ Traverse 2} & \multicolumn{2}{|c|}{ Traverse 3} \\
\hline & $\begin{array}{l}\text { Ident if ication } \\
\text { Number }\end{array}$ & $\begin{array}{l}\text { Hardness, } \\
\text { HRA }\end{array}$ & $\begin{array}{l}\text { Identification } \\
\text { Number }\end{array}$ & $\begin{array}{l}\text { Hardness, } \\
\text { HRA }\end{array}$ & $\begin{array}{l}\text { Identification } \\
\text { Number }\end{array}$ & $\begin{array}{l}\text { Hardness } \\
\text { HRA }\end{array}$ \\
\hline Base Metal & $\begin{array}{l}1 \\
2\end{array}$ & $\begin{array}{l}50.5 \\
51.5\end{array}$ & $\begin{array}{l}1 \\
2 \\
3 \\
4\end{array}$ & $\begin{array}{l}48 \\
50.5 \\
50.5 \\
50\end{array}$ & $\begin{array}{l}1 \\
2\end{array}$ & $\begin{array}{l}52 \\
52\end{array}$ \\
\hline HAZ & $\begin{array}{l}3 \\
4 \\
5\end{array}$ & $\begin{array}{l}52 \\
53.5 \\
54.5\end{array}$ & $\begin{array}{l}5 \\
6 \\
7\end{array}$ & $\begin{array}{l}50.5 \\
53 \\
53\end{array}$ & $\begin{array}{l}3 \\
4 \\
5 \\
6\end{array}$ & $\begin{array}{l}52 \\
54 \\
54 \\
54\end{array}$ \\
\hline Weld Metal & $\begin{array}{r}6 \\
7 \\
8 \\
9 \\
10 \\
11 \\
12\end{array}$ & $\begin{array}{l}54 \\
54 \\
54 \\
53.5 \\
54 \\
53 \\
52\end{array}$ & $\begin{array}{r}8 \\
9 \\
10 \\
11\end{array}$ & $\begin{array}{l}52 \\
52 \\
51 \\
51\end{array}$ & $\begin{array}{r}7 \\
8 \\
9 \\
10\end{array}$ & $\begin{array}{l}53.5 \\
53.5 \\
53.5 \\
53\end{array}$ \\
\hline HAZ & $\begin{array}{l}13 \\
14 \\
15\end{array}$ & $\begin{array}{l}53 \\
53 \\
52\end{array}$ & $\begin{array}{l}12 \\
13\end{array}$ & $\begin{array}{l}51 \\
50\end{array}$ & $\begin{array}{l}11 \\
12 \\
13\end{array}$ & $\begin{array}{l}53 \\
53.5 \\
52.5\end{array}$ \\
\hline Base Metal & 16 & 51 & $\begin{array}{l}14 \\
15\end{array}$ & $\begin{array}{l}49 \\
49.5\end{array}$ & 14 & 52.5 \\
\hline
\end{tabular}

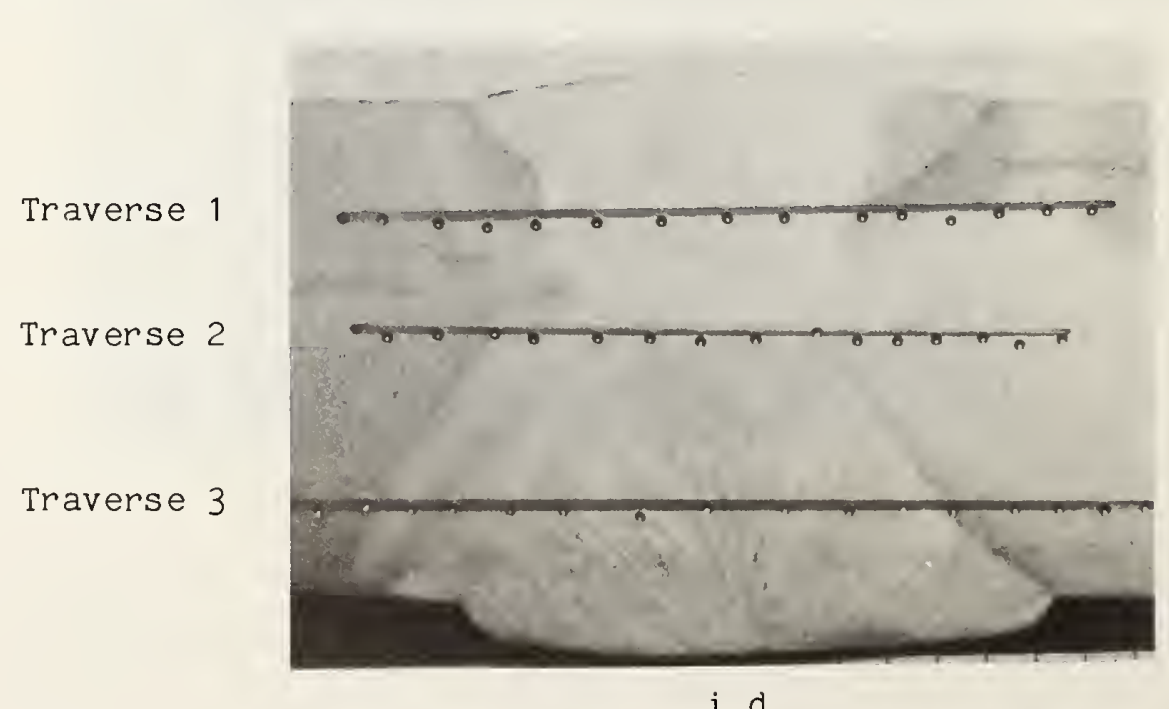

i.d

Figure D8. Hardness traverses across the vertical weld in Course 1. 


\begin{tabular}{|c|c|c|c|c|}
\hline & \multicolumn{2}{|c|}{ Traverse 1} & \multicolumn{2}{|c|}{ Traverse 2} \\
\hline & $\begin{array}{l}\text { Ident if ication } \\
\text { Number }\end{array}$ & $\begin{array}{l}\text { Hardness, } \\
\text { HRA }\end{array}$ & $\begin{array}{l}\text { Identification } \\
\text { Number }\end{array}$ & $\begin{array}{l}\text { Hardness, } \\
\text { HRA }\end{array}$ \\
\hline Base Metal & $\begin{array}{l}1 \\
2\end{array}$ & $\begin{array}{l}53.5 \\
53.5\end{array}$ & $\begin{array}{l}1 \\
2 \\
3 \\
4\end{array}$ & $\begin{array}{l}52 \\
52.5 \\
52.5 \\
52.5\end{array}$ \\
\hline HAZ & $\begin{array}{l}3 \\
4 \\
5 \\
6\end{array}$ & $\begin{array}{l}53 \\
53.5 \\
53 \\
53\end{array}$ & $\begin{array}{l}5 \\
6 \\
7\end{array}$ & $\begin{array}{l}51.5 \\
52.5 \\
53\end{array}$ \\
\hline Weld Metal & $\begin{array}{r}7 \\
8 \\
9 \\
10\end{array}$ & $\begin{array}{l}52 \\
52 \\
52 \\
51.5\end{array}$ & $\begin{array}{r}8 \\
9 \\
10 \\
11 \\
12 \\
13 \\
14\end{array}$ & $\begin{array}{l}52.5 \\
53.5 \\
54.5 \\
54 \\
54 \\
54 \\
53.5\end{array}$ \\
\hline $\mathrm{HAZ}$ & $\begin{array}{l}11 \\
12 \\
13\end{array}$ & $\begin{array}{l}5 i \\
5 i \\
50\end{array}$ & $\begin{array}{l}15 \\
16 \\
17\end{array}$ & $\begin{array}{l}54.5 \\
53 \\
52\end{array}$ \\
\hline Base Metal & $\begin{array}{l}14 \\
15 \\
16\end{array}$ & $\begin{array}{l}50.5 \\
51 \\
50.5\end{array}$ & $\begin{array}{l}18 \\
19 \\
20\end{array}$ & $\begin{array}{l}51 \\
52 \\
51.5\end{array}$ \\
\hline
\end{tabular}

Traverse 1

Traverse 2

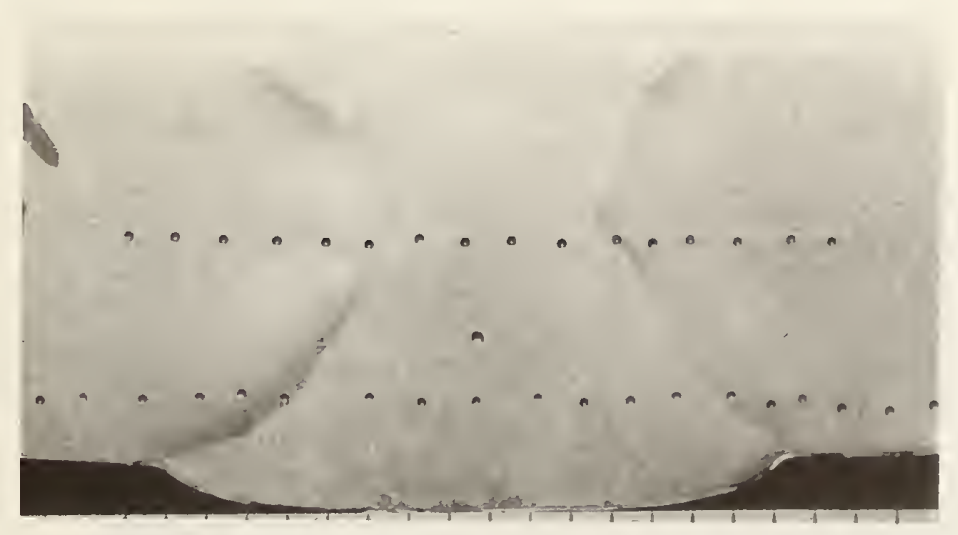

$$
\text { i.d. }
$$

Figure D9. Hardness traverses across the vertical weld in Course 3. 


\begin{tabular}{|c|c|c|c|c|}
\hline & Travers & 1 & Travers & \\
\hline & $\begin{array}{l}\text { Identification } \\
\text { Number }\end{array}$ & $\begin{array}{l}\text { Hardness, } \\
\text { HRA } \\
\end{array}$ & $\begin{array}{l}\text { Identification } \\
\text { Number }\end{array}$ & $\begin{array}{l}\text { Hardness } \\
\text { HRA } \\
\end{array}$ \\
\hline Base Metal & $\begin{array}{l}1 \\
2 \\
3 \\
4\end{array}$ & $\begin{array}{l}50 \\
52.5 \\
53 \\
52\end{array}$ & $\begin{array}{l}1 \\
2 \\
3 \\
4\end{array}$ & $\begin{array}{l}51.5 \\
52 \\
51.5 \\
51.5\end{array}$ \\
\hline HAZ & $\begin{array}{l}5 \\
6 \\
7 \\
8\end{array}$ & $\begin{array}{l}52 \\
52 \\
53.5 \\
54\end{array}$ & 5 & 52 \\
\hline Weld Metal & $\begin{array}{r}9 \\
10 \\
11 \\
12 \\
13 \\
14\end{array}$ & $\begin{array}{l}53.5 \\
54 \\
53.5 \\
53.5 \\
54 \\
53.5\end{array}$ & $\begin{array}{r}6 \\
7 \\
8 \\
9 \\
10\end{array}$ & $\begin{array}{l}52 \cdot 5 \\
52 \\
52 \cdot 5 \\
52 \\
52\end{array}$ \\
\hline HAZ & $\begin{array}{l}15 \\
16 \\
17\end{array}$ & $\begin{array}{l}54 \\
53.5 \\
53\end{array}$ & $\begin{array}{l}11 \\
12\end{array}$ & $\begin{array}{l}53 \\
53\end{array}$ \\
\hline Base Metal & $\begin{array}{l}18 \\
19\end{array}$ & $\begin{array}{l}52.5 \\
53\end{array}$ & $\begin{array}{l}13 \\
14\end{array}$ & $\begin{array}{l}52 \\
52.5\end{array}$ \\
\hline
\end{tabular}

Traverse 1

Traverse 2

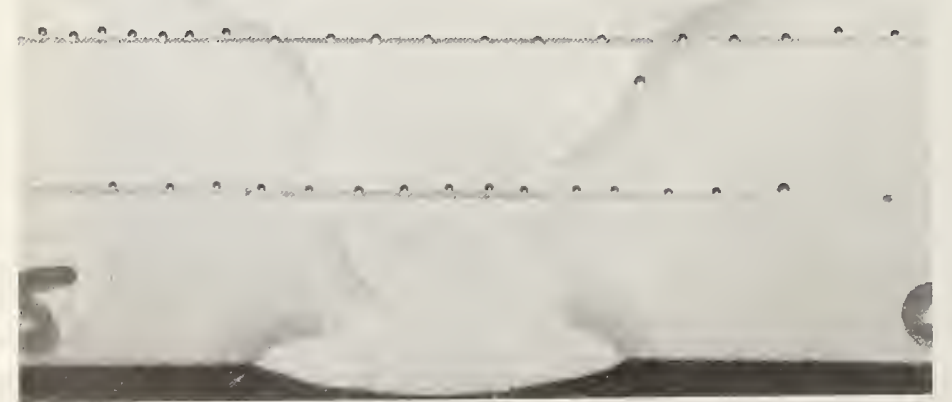

i.d.

Figure D10. Hardness traverses across the vertical weld in Course 5 . 
APPENDIX E - y-GROOVE CRACKING TEST

December 1985

Prepared by: Thomas A. Siewert

Fracture and Deformation Division

Institute for Materials Science and Engineering National Bureau of Standards

Boulder, Colorado 80303 



\section{y-GROOVE CRACKING TEST}

\section{IN TRODUCTION}

This test evaluates the cracking tendency of a base material-electrode combination to cold (also known as delayed or hydrogen) cracking. E1 In this study, all tests were performed with rebaked electrodes, which reduced the hydrogen contribution of the electrodes to a low and constant level. Thus the test evaluated only the cracking sensitivity of the heat-affected zone (HAZ) in the base material. The test compared three material combinations and conditions that might have been present during the replacement of Course 2 of the vessel.

\section{TEST DESCRIPTION}

The test consists of a weld between two pieces of base material, each $200 \mathrm{~mm}$ by $75 \mathrm{~mm}$ ( $7.9 \mathrm{in}$. by $3.0 \mathrm{in.}$ ) by the plate thickness. As the name implies, the test has a groove in the shape of a lower-case y (Eig. E1). The groove shape is produced by forming a butt joint along the $200 \mathrm{~mm}$ (7.9 in.) side of the plates, one having a single bevel and the other a double bevel, and both having a 30 degree bevel angle.

The important feature of this test is the severe, but constant, lateral restraint imposed by the weld on the surrounding HAZ. This restraint is established and controlled by (1) fixing the root opening at $2 \pm 0.2 \mathrm{~mm}$ ( 0.08 in.) when measured normal to the bevel surfaces and (2) filling the outer $60 \mathrm{~mm}$ ( $2.4 \mathrm{in.}$ ) of the groove at each end of the plate with stringer beads before the center (test) section is welded. A $4 \mathrm{~mm}$ ( 0.16 in.) diameter type AWS E7018 electrode was rebaked at $250^{\circ} \mathrm{C}\left(482^{\circ} \mathrm{F}\right.$ ) for at least $4 \mathrm{~h}$ before being used for both the restraint and the test welds in each specimen. The welding was performed by the shielded metal-arc process at $170 \pm 10 \mathrm{~A}$ and $26 \pm 3 \mathrm{~V}$, with a travel speed of 10 to $15 \mathrm{~cm} / \mathrm{min}(3.9$ to $5.9 \mathrm{in.} / \mathrm{min}$.). 

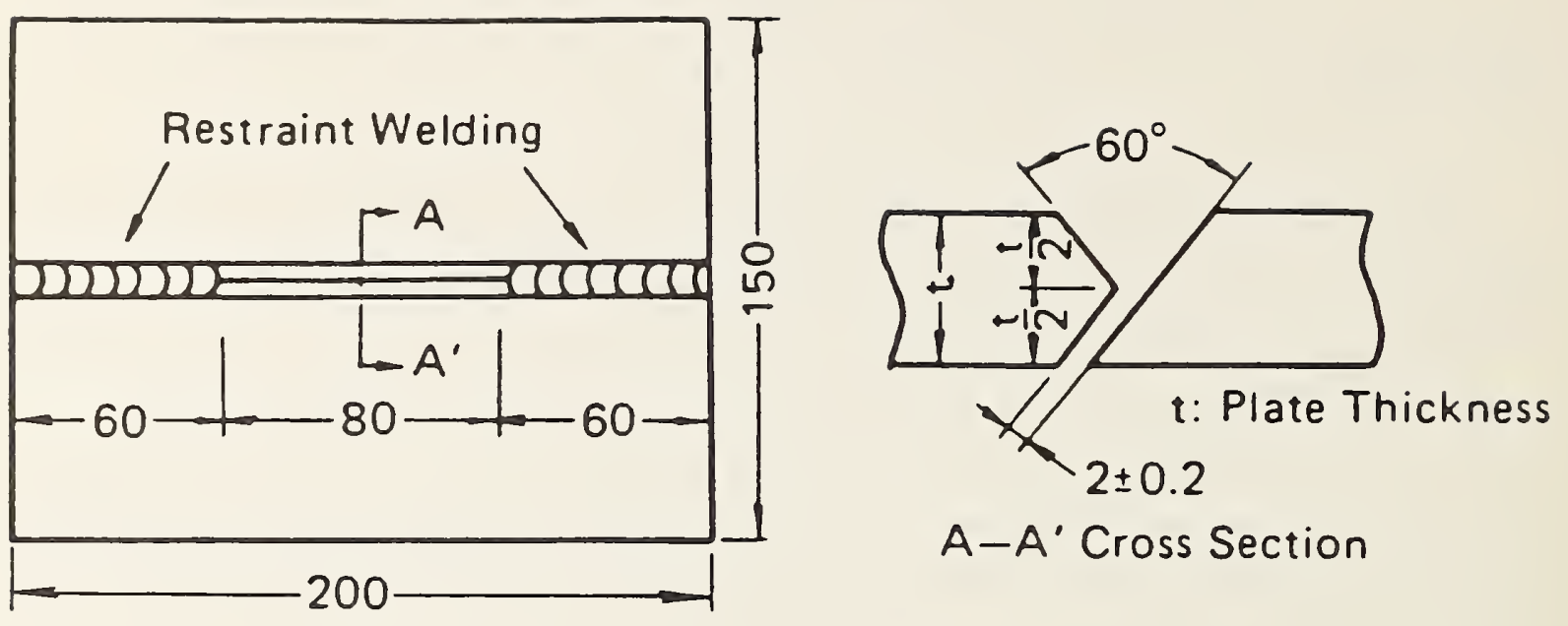

Figure E1. Plate and groove dimensions $(\mathrm{mm})$ for the y-groove cracking test.

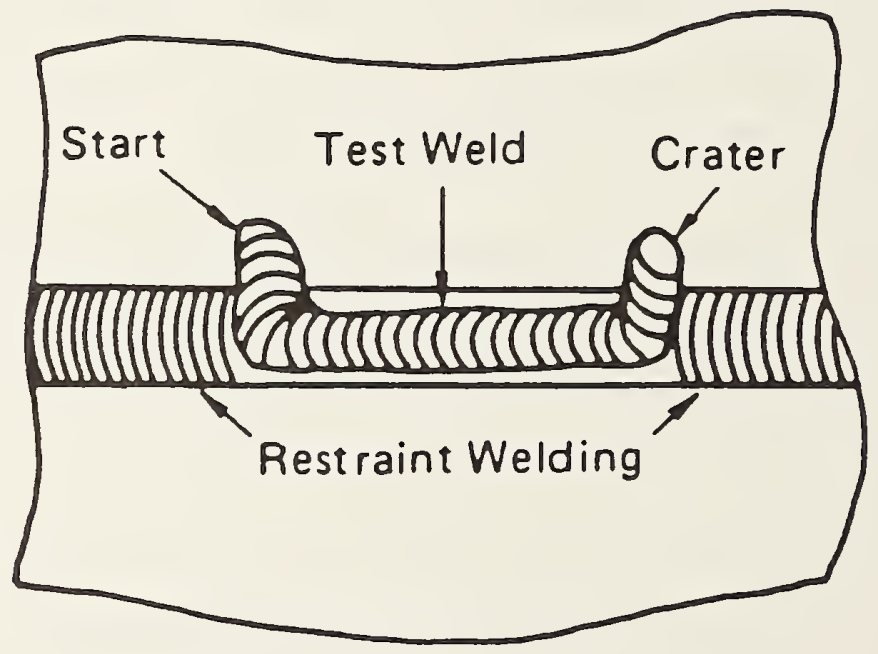

Figure E2. Schematic of the weld progression in the center section. 
The center $80 \mathrm{~mm}$ ( $3 \mathrm{in.)}$ length of the groove was evaluated for cracking. After the restraint welds had been completed, the specimen was allowed to stabilize at the desired temperature before the final weld was begun. The weld began on the plate surface to eliminate arc starting effects, traveled down into and along the groove, and ascended again to the plate surface to eliminate arc crater effects (Fig. E2). The time the electrode was in the groove and the length of the groove were measured to determine whether the desired travel speed was achieved.

\section{TESTS OF THREE SPEC IMENS}

The first specimen was composed of two plates from Course 1, with no subsequent treatments other than slight straightening and machining of the bevels. The plates were separated with $2 \mathrm{~mm}$ (0.08 in.) shims and clamped to align the restraint welds. Even with continuous welding, the plate temperatures did not exceed $150^{\circ} \mathrm{C}\left(302^{\circ} \mathrm{F}\right)$, as measured with temperatureindicating crayons. The specimen was allowed to cool to $20^{\circ} \mathrm{C}\left(68^{\circ} \mathrm{F}\right)$ before the center $80 \mathrm{~mm}$ ( $3 \mathrm{in}$.) section was welded. A travel speed of $16 \mathrm{~cm} / \mathrm{min}$. (6.3 in./min,) was measured for this center section. After the completion of welding, the specimen was kept at $20^{\circ} \mathrm{C}\left(68^{\circ} \mathrm{F}\right)$ during a one-week crack incubation period.

The second specimen was composed of two plates from Course 2, with no subsequent treatments other than slight straightening and machining of the bevels. The clamping and welding details were the same as for Specimen 1. A travel speed of $15 \mathrm{~cm} / \mathrm{min}$ ( $5.9 \mathrm{in./min.)}$ was measured for the center section. As for specimen 1 , specimen 2 was kept at $20^{\circ} \mathrm{C}\left(68^{\circ} \mathrm{F}\right)$ during a one-week crack incubation period.

The third specimen was composed of one plate from Course 1 and one plate from course 2. Both plates were straightened slightly and the groove bevels were machined. The plate from Course 1 was charged with hydrogen by immersion for $80 \mathrm{~h}$ in the NACE (Standard TM-01-77) solution; the plate from Course 2 was not hydrogen charged. Since the hydrogen began to diffuse from the plate immediately after removal from the charging bath, the specimen was prepared for the test weld as rapidly as possible. Within 10 min. after 
removing the Course 1 plate from the solution, it was welded to the Course 2 plate at the specimen ends (the restraint welds). The welding conditions were essentially the same as those used for Specimens 1 and 2 . Immediately after the restraint welds were completed, the specimen was placed in a refrigerator and cooled to $1^{\circ} \mathrm{C}\left(34^{\circ} \mathrm{F}\right)$. This temperature reduced the loss of hydrogen from the plate before the test weld and simulated the lower temperatures that may have existed in the vessel during fabrication. For the first three days after completion of the test weld, specimen 3 was kept at $1^{\circ} \mathrm{C}\left(34^{\circ} \mathrm{F}\right)$. For the final four days of the crack incubation period, the specimen was kept at $20^{\circ} \mathrm{C}\left(68^{\circ} \mathrm{F}\right)$ to simulate the increased diffusion that would occur as the vessel was heated.

\section{CRACKING EVALUATION}

Since hydrogen cracking is a phenomenon based on diffusion, the examination for cracking must be delayed until the cracking has time'to occur. This procedure allowed a seven-day incubation period for the hydrogen to have its effect on the weld region. At the end of that time, the weld surface was examined by a dye-penetrant technique.

After this nondestructive examination, the center (test) weld was sectioned transverse to the weld at five evenly spaced locations. These sections were also examined for cracking in the HAZ. The cracking was expressed as a percentage of the HAZ length normal to the welding direction,

$$
C L_{n}(\%)=\frac{\sum i}{I}
$$

where $C L_{n}$ is the percentage of cracking along the HAZ root and toe of the bead on a section normal to the weld direction, $i$ is the length of individual cracks along the $\mathrm{HAZ}$, and $\mathrm{I}$ is the total length of the interface between the root and toe of the weld.

We also monitored the crack growth during the seven-day crack incubation period. The weld surface was inspected with a magnetic particle technique on the third, fifth, and seventh day of the test. 


\section{RESULTS}

The results of the examination of the three specimens are summarized in Table EI. No cracking was found in Tests 1 and 2 during either the nondestructive examination of the weld bead surface or the subsequent examination of the weld cross section on the seventh day after welding.

No cracking was found in Test 3 during the nondestructive examination of the weld bead surface. However, cracking was found in the examination of the weld cross section. A typical section through the weld, Figure E3, reveals a rounded bead with good penetration into the sides. The crack is visible in a higher magnification view, Figure E4, extending from the root along the Plate 1 (hydrogen-charged) side of the groove. The crack was always in the HAZ on the Plate 1 side of the groove and was consistently near 20\% of the leg length (distance from the toe to the root of the weld).

REFERENCE

E1. Yurioki, N.; Suzuki, H.; Ohshita, S.; and Saito, S. Determination of Necessary Preheating Temperature in Steel Welding. Welding Journal 62 (6), 1983, pp. 147s-153s. 
Table EI. Results for the y-groove cracking tests.

\begin{tabular}{|c|c|c|c|c|c|}
\hline \multirow{2}{*}{$\begin{array}{l}\text { Test } \\
\text { Number }\end{array}$} & \multirow{2}{*}{$\begin{array}{l}\text { Base } \\
\text { Material }\end{array}$} & \multirow{2}{*}{$\begin{array}{l}\text { Material } \\
\text { Condition }\end{array}$} & \multirow{2}{*}{$\begin{array}{l}\text { Preheat } \\
\text { Temperature }\end{array}$} & \multicolumn{2}{|c|}{ Cracks } \\
\hline & & & & Surface & Cross Section \\
\hline 1 & $\begin{array}{l}\text { Course } 1 \\
\text { welded to }\end{array}$ & As Received & $20^{\circ} \mathrm{C}\left(68^{\circ} \mathrm{F}\right)$ & None & None \\
\hline & Course 1 & As Received & & & \\
\hline 2 & $\begin{array}{l}\text { Course } 2 \\
\text { welded to }\end{array}$ & & $20^{\circ} \mathrm{C}\left(68^{\circ} \mathrm{F}\right)$ & None & None \\
\hline & Course 2 & As Received & & & \\
\hline 3 & $\begin{array}{l}\text { Course } 1 \\
\text { welded to } \\
\text { Course } 2\end{array}$ & $\begin{array}{l}\mathrm{H}_{2} \text { Charged } \\
\text { As Received }\end{array}$ & $1^{\circ} \mathrm{C}\left(34^{\circ} \mathrm{F}\right)$ & None & $20 \%^{*}$ \\
\hline
\end{tabular}

* Cracking confined to HAZ on the Course 1 side of the specimen. 


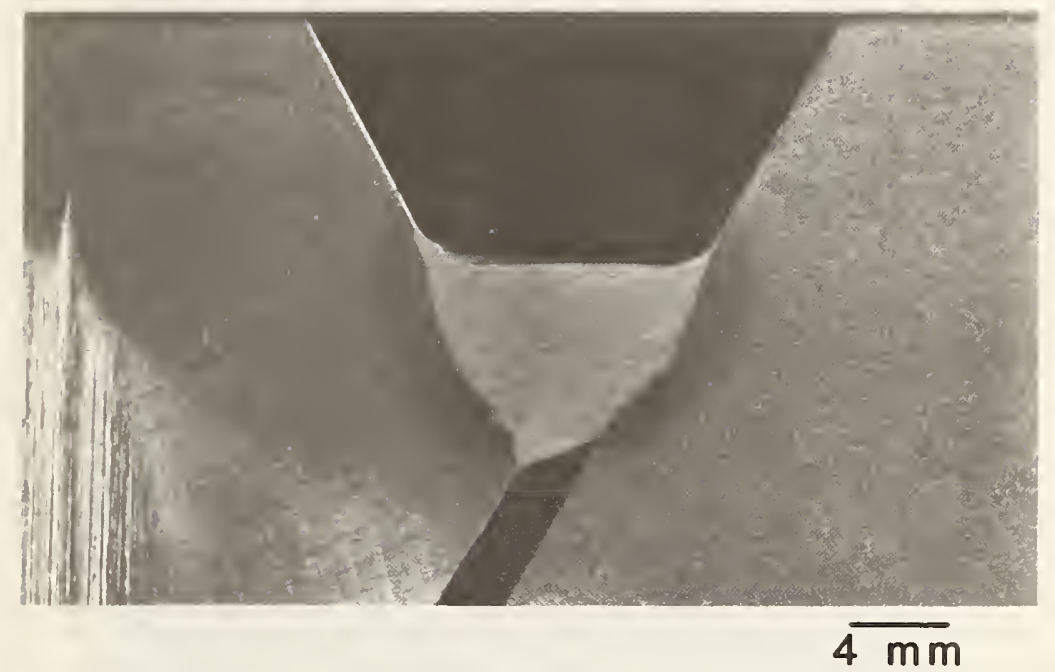

Figure E3. Typical cross section of the weld at the center (test) section of Specimen 3. 


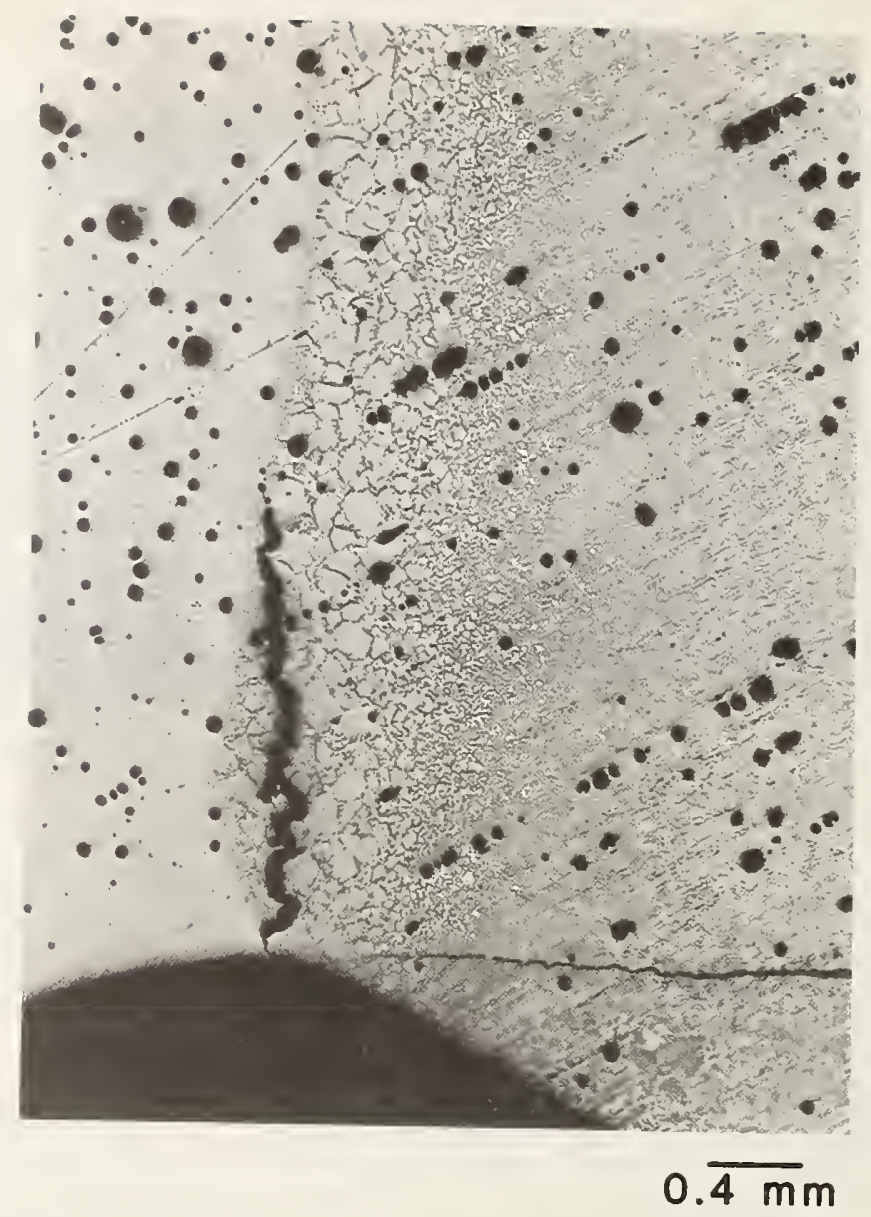

Figure E4. Typical crack along the HAZ in the Plate 1 side of the groove, extending $20 \%$ of the leg length from the weld root. 


\section{APPENDIX F - REPORT OF ANALYSIS BY THE ELECTRON PROBE MICROANALYZER OF FRACTURE SURFACE SPECIMENS}

October 1985

Prepared by: Ryna Marinenko

Gas and Particulate Science Division

Center for Analytical Chemistry

National Bureau of Standards

Wa sh ington, D. C. 20234

Approved by: Dale E. Newbury

Harry L. Rook

Gas and Particulate Science Division

Center for Analytical Chemistry

National Bureau of Standards

Wash ington, D. C. 20234

NOTE: The specimens submitted by Robert Shives for analysis were taken from the following locations:

Ring 1 at $\mathrm{CC} 2.0 \mathrm{~m}(\mathrm{G}-6-5-1)$

Ring 1 at $\mathrm{CC} 5.5 \mathrm{~m}(\mathrm{G}-18-1)$

Ring 1 at CC $7.5 \mathrm{~m}(24-\mathrm{C} 1)$ - not analyzed

Ring 1 at $\mathrm{CC} 7.7 \mathrm{~m}(25-3 / 8 \mathrm{C} 1)$

Ring 2 at CC $1.0 \mathrm{~m}(\mathrm{G}-3-5-2)$

Ring 2 at $\mathrm{CC} 7.2 \mathrm{~m}(25-3 / 8 \mathrm{C} 2)$

Ring 2 at CC $7.2 \mathrm{~m}(25-3 / 8 \mathrm{C} 20)$ 

REPORT OF ANALYSIS BY THE ELECTRON PROBE MICROANALYZER OF FRACTURE SURFACE SPECIMENS

DESCRIPTION OF SPECIMEN

Seven metal pieces, each with one corroded surface were submitted for electron microprobe analysis. Each piece is about $1 \mathrm{~cm} \times 5 \mathrm{~mm} \times 5 \mathrm{~mm}$. The first four specimens are labeled G-18-1 (red, inside), G-3-5-2 (brown), G-6-5-1 (black), and G-6-5-1 (dark brown). Three others, which were submitted later, are labeled 25-3/8C1 (RD25C1), 25-3/8C2(DK25C2), and 24-C1. Also, there is one sample mount containing two cross sections, one labeled 25-3/8c2 and the other labeled "out."

\section{REQUEST}

Qualitative analysis of the corrosion layer on the metal fracture surface.

RESULTS

The rough specimens were mounted for in situ analysis with the electron microprobe using the energy dispersive detector. Several areas were analyzed on each specimen with a point beam. A short description of the appearance of the region analyzed on each specimen and the elemental results of the analysis are listed in Table FI. For each analysis, the major elements are listed on the first line, lower-concentration elements, estimated to be less than 10 percent, are on the second line, and those elements present in very small quantities, probably less than one percent, are on the third line. The major elements on the first line are listed in order of the largest peak first. Iron, which originates from the steel matrix, is the major constitutent in most of the spectra. Sulphur and/or silicon occur in large amounts in many areas. Several other elements, including sodium, magnesium, aluminum, phosphorus, chlorine, potassium, calcium, titanium, manganese, chromium, and zinc, are generally present in much smaller amounts. A few examples of the EDS spectra observed are in Figure F1. Spectrum A was taken from the white 
Table FI. EDS qualitative analysis of rough specimens from fracture surface (Union Oil)

\begin{tabular}{|c|c|c|c|c|}
\hline Specimen & ctrum & & Region Analyzed & \\
\hline \multirow[t]{2}{*}{$\begin{array}{l}\text { G-18-8-1 } \\
\text { R1 (Red) }\end{array}$} & 1 & $\begin{array}{l}\quad \text { RED } \\
\mathrm{Fe} \\
\mathrm{Si}, \mathrm{S}, \mathrm{Ca}, \mathrm{Mn} \\
\mathrm{Zn}, \mathrm{Mg}, \mathrm{Al}, \mathrm{P}, \mathrm{K}\end{array}$ & $\begin{array}{l}\text { WHITE CRYSTALLINE } \\
\begin{array}{l}\mathrm{S}+\mathrm{Fe} \\
\mathrm{Si}, \mathrm{Ca}, \mathrm{Mn} \\
\mathrm{AI}, \mathrm{Zn}, \mathrm{P}, \mathrm{Mn}, \mathrm{Mg}\end{array}\end{array}$ & $\begin{array}{l}\quad \text { BLACK } \\
\mathrm{Fe}+\mathrm{S} \\
\mathrm{S} 1, \mathrm{P}, \mathrm{Ca} \\
\mathrm{Al}, \mathrm{K}, \mathrm{Mg}, \mathrm{Mn}\end{array}$ \\
\hline & 2 & $\begin{array}{l}\mathrm{Fe} \\
\mathrm{Si}, \mathrm{P}, \mathrm{S}, \mathrm{Ca}, \mathrm{Mn} \\
\mathrm{A} 1\end{array}$ & $\begin{array}{l}\mathrm{S} \\
\mathrm{Si}, \mathrm{Fe}, \mathrm{K}, \mathrm{Al}, \mathrm{P} \\
\mathrm{Ca}, \mathrm{Mn}, \mathrm{Zn}, \mathrm{Mg}\end{array}$ & $\begin{array}{l}\mathrm{Fe} \\
\mathrm{S}, \mathrm{Si}, \mathrm{Mn} \\
\mathrm{Al}, \mathrm{P}, \mathrm{Cl}\end{array}$ \\
\hline \multirow[t]{4}{*}{$\begin{array}{l}G-3-5-2 \\
(\text { Brown })\end{array}$} & 1 & $\begin{array}{l}\text { YELLOW-RED } \\
\text { Fe } \\
\text { Si, P, S } \\
\mathrm{Al}, \mathrm{K}, \mathrm{Ca}, \mathrm{Mn}, \mathrm{Zn}, \mathrm{C} 1\end{array}$ & 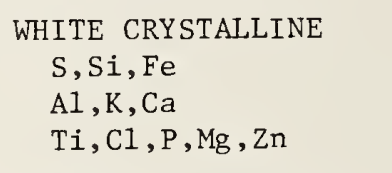 & $\begin{array}{l}\text { DARK } \\
\mathrm{Fe} \\
\mathrm{Si}, \mathrm{P}, \mathrm{S}, \mathrm{Ca}, \mathrm{Mn} \\
\mathrm{Al}, \mathrm{K}, \mathrm{Zn}, \mathrm{Mg}, \mathrm{Cr}\end{array}$ \\
\hline & 2 & $\begin{array}{l}\mathrm{Fe} \\
\mathrm{Si}+\mathrm{A} 1, \mathrm{P}, \mathrm{S} \\
\mathrm{Zn}, \mathrm{K}, \mathrm{Ca}, \mathrm{Mn}, \mathrm{Ti}\end{array}$ & $\begin{array}{l}\mathrm{Fe} \\
\mathrm{Si}+\mathrm{P}, \mathrm{S}, \mathrm{Cl}, \mathrm{Ca}, \mathrm{Al} \\
\mathrm{K}, \mathrm{Ca}, \mathrm{Zn}, \mathrm{Mn}, \mathrm{Mg}, \mathrm{Ti}\end{array}$ & $\begin{array}{l}\mathrm{Fe} \\
\mathrm{Si}+\mathrm{A} 1, \mathrm{~K}, \mathrm{~S} \\
\mathrm{Ca}, \mathrm{Ti}, \mathrm{Mn}, \mathrm{Zn}, \mathrm{P}, \mathrm{Mg}\end{array}$ \\
\hline & 3 & $\begin{array}{l}\mathrm{Fe} \\
\mathrm{Si}+\mathrm{Al}, \mathrm{P}, \mathrm{S} \\
\mathrm{Zn}, \mathrm{K}, \mathrm{Ca}, \mathrm{Mn}, \mathrm{T}\end{array}$ & $\begin{array}{l}\mathrm{Si}+\mathrm{Fe} \\
\mathrm{Al}, \mathrm{S} \\
\mathrm{K}, \mathrm{Cl}, \mathrm{P}, \mathrm{Ca}, \mathrm{Mn}, \mathrm{Zn}, \mathrm{Mg}\end{array}$ & \\
\hline & 4 & & $\begin{array}{l}\mathrm{Ca}+\mathrm{Fe}, \mathrm{Si}+\mathrm{Mg} \\
\mathrm{P}, \mathrm{S}, \mathrm{K}, \mathrm{Zn}, \mathrm{Ti}, \mathrm{Mn}, \mathrm{Al}\end{array}$ & \\
\hline \multirow[t]{3}{*}{$\begin{array}{l}\text { G-6-5-1 } \\
(\text { Black) }\end{array}$} & 1 & $\begin{array}{l}\text { DARK RED } \\
\text { Fe+S } \\
\mathrm{Si}, \mathrm{P}, \mathrm{Mn}, \mathrm{Ca} \\
\mathrm{Zn}, \mathrm{Al}, \mathrm{K}\end{array}$ & $\begin{array}{l}\text { WHITE CRYSTALLINE } \\
\text { Si+Fe, S+Mg, Ca } \\
\text { Ti } \\
\text { K, Mn, Al }\end{array}$ & $\begin{array}{l}\quad \text { BLACK } \\
\mathrm{Fe}+\mathrm{S} \\
\mathrm{Si}, \mathrm{Ca}, \mathrm{K}, \mathrm{Mn}, \mathrm{P}, \mathrm{Al} \\
\mathrm{Mg}, \mathrm{Zn}\end{array}$ \\
\hline & 2 & & $\begin{array}{l}\mathrm{S} \\
\mathrm{Fe}, \mathrm{Ti}\end{array}$ & $\begin{array}{l}\mathrm{Fe} \\
\mathrm{Si}, \mathrm{S} \\
\mathrm{P}, \mathrm{Ca}, \mathrm{Mn}, \mathrm{Zn}\end{array}$ \\
\hline & 3 & & $\begin{array}{l}\text { REDDISH WHITE } \\
\text { S+Fe } \\
\mathrm{Zn}, \mathrm{Si} \\
\mathrm{A} 1, \mathrm{P}, \mathrm{Ca}, \mathrm{K}, \mathrm{Mn}\end{array}$ & \\
\hline \multirow[t]{2}{*}{$\begin{array}{l}\text { G-6-5-1 } \\
\text { (Dark brown) }\end{array}$} & 1 & $\begin{array}{l}\text { DARK RED } \\
\text { Fe+AI } \\
\text { Si, S } \\
M n, \mathrm{Zn}, \mathrm{Ca}, \mathrm{Mg}, \mathrm{P}, \mathrm{Ti}\end{array}$ & $\begin{array}{l}\text { WHITE CRYSTALLINE } \\
\qquad \mathrm{AI+Fe} \\
\text { S, Si } \\
\text { Ca,Ti }\end{array}$ & $\begin{array}{l}\text { BLACK } \\
- \\
\mathrm{Mn}\end{array}$ \\
\hline & 2 & $\begin{array}{l}\mathrm{Fe} \\
- \\
\mathrm{S}, \mathrm{Al}, \mathrm{Mn}\end{array}$ & $\begin{array}{l}\mathrm{Fe}+\mathrm{S} \\
\quad- \\
\mathrm{A} 1, \mathrm{Si}, \mathrm{Cl}, \mathrm{Ca}\end{array}$ & \\
\hline $\begin{array}{l}25-3 / 8 C 1 \\
(\mathrm{RD} 25 \mathrm{Cl})\end{array}$ & 1 & $\begin{array}{l}\quad \text { RED } \\
\text { Fe } \\
\mathrm{S}+\mathrm{Si}, \mathrm{Mn}\end{array}$ & $\begin{array}{l}\text { WHITE CRYSTALLINE } \\
\text { P+Ca, Fe } \\
\quad- \\
\text { Mg, } \mathrm{Mn}, \mathrm{Al}, \mathrm{Si}, \mathrm{S}, \mathrm{Cl}\end{array}$ & DARK \\
\hline \multirow[t]{2}{*}{$\begin{array}{l}25-3 / 8 C 2 \\
(\mathrm{DK} 25 \mathrm{C} 2)\end{array}$} & 1 & & $\begin{array}{l}\text { WHITE CRYSTALLINE } \\
\text { Si+Fe } \\
\text { S, Ti } \\
\text { Ca, } \mathrm{Al}, \mathrm{P}, \mathrm{Cl}, \mathrm{Mn}, \mathrm{Zn}\end{array}$ & $\begin{array}{l}\quad \text { DARK } \\
\text { Fe+S, Si } \\
\text { Mn } \\
\text { K, Ca }\end{array}$ \\
\hline & 2 & & & $\begin{array}{l}\mathrm{S}+\mathrm{Fe} \\
\mathrm{Si} \\
\mathrm{K}, \mathrm{Ca}, \mathrm{Mn}, \mathrm{P}, \mathrm{Zn}\end{array}$ \\
\hline
\end{tabular}



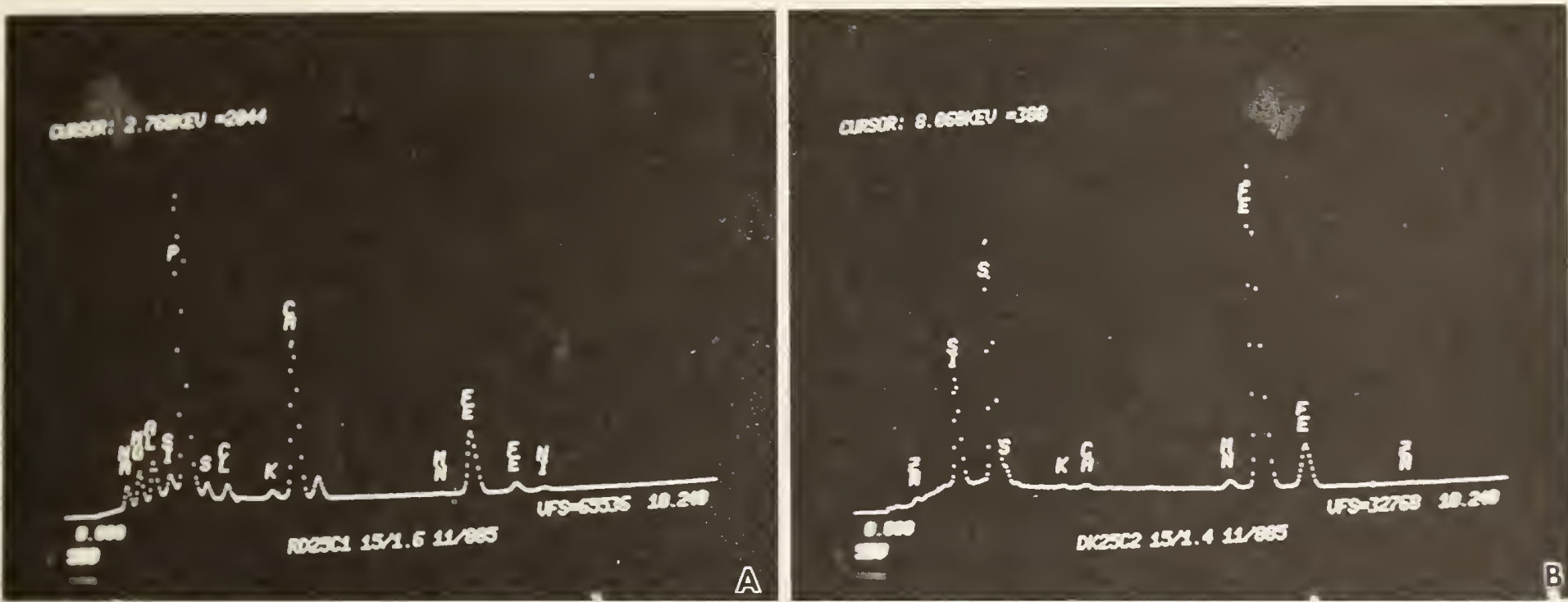

A. White crystalline material in $\mathrm{RD} 25 \mathrm{Cl}$

B. Dark material in DK25C2.

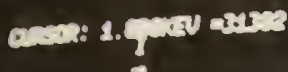

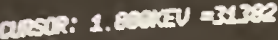

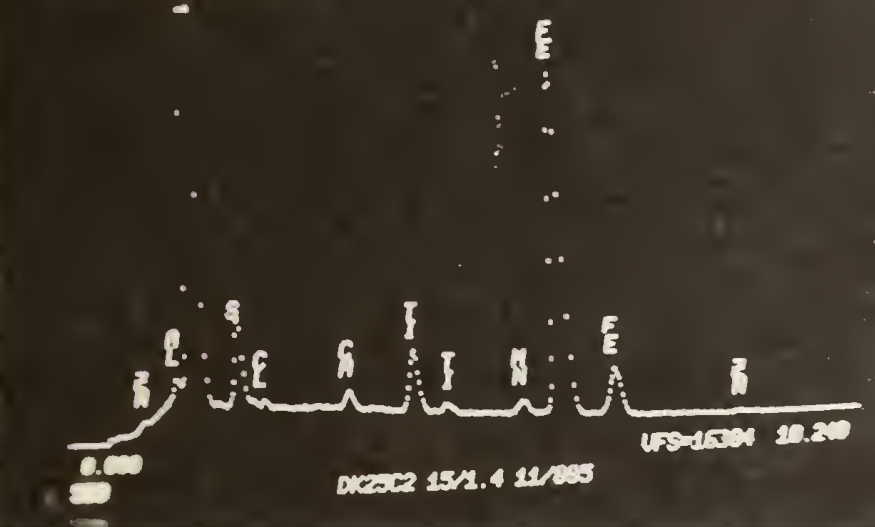

C

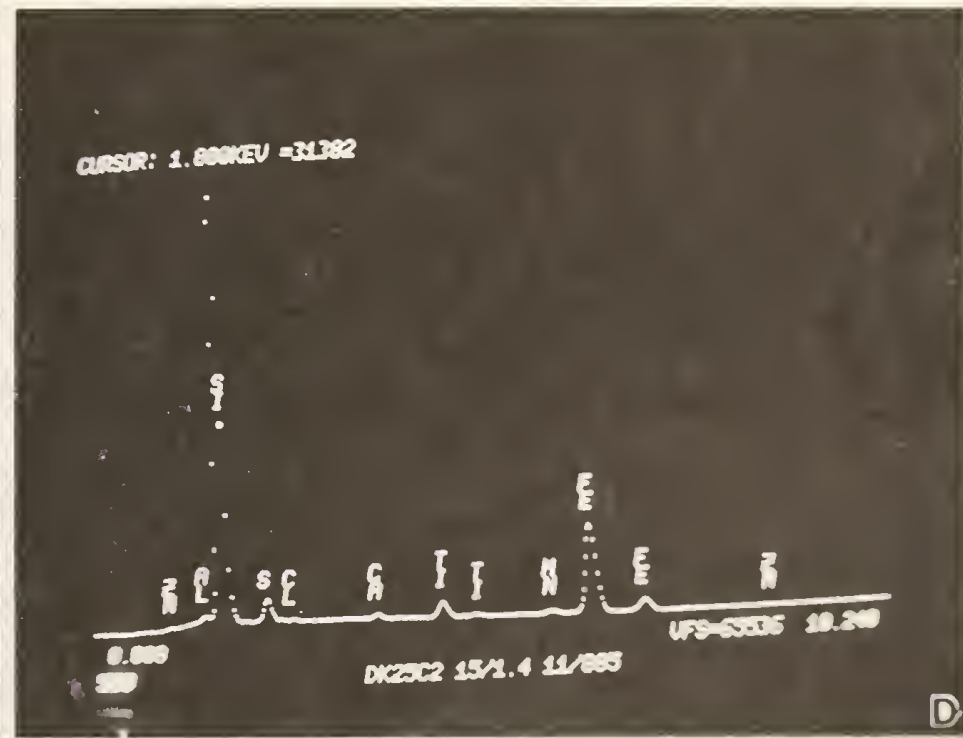

C. White crystalline material in $\mathrm{DK} 25 \mathrm{C} 2$

D. Reduced scale of $\mathrm{C}$.

Figure F1. Examples of the EDS spectra (all are Sepctrum 1 in Table FI). 
crystalline material in RD25C1 (spectrum 1 in Table FI) B was taken from the dark material in DK25C2 (spectrum 1 in Table FI) and $\mathrm{C}$ was taken from the white crystalline material in DK25C2 (spectrum 1 in Table FI). Spectrum D is a reduced scale of $C$. Based upon the qualitative analyses of the fracture surfaces, two samples were selected for analysis in cross section.

The sample mount with the two cross sections was carbon coated. Digital X-ray maps were taken of three differert pitted areas on the metal surface of these specimens. These maps are prepared by positioning the electron beam point-by-point on the specimen in an array pattern with a preselected distance between points. At each point $X$-ray counts for the elements of interest are integrated for a selected time period. The maps in this report were taken at a magnification of $300 \mathrm{x}$, which covers an area slightly larger than $300 \times 300 \mu \mathrm{m}$. A $128 \times 128$ point array was used. Therefore, there were approximately $2.6 \mu \mathrm{m}$ between the centers of adjacent points. The three maps were taken with wavelength spectrometers (WDS) on the elements iron, sulfur, and silicon. The WDS maps were ratioed to identical maps taken of the standard elements. To do this, each point of the unknown map is ratioed to the corresponding point of a map taken of a standard specimen containing the element of interest. This was done to correct spectrometer defocussing, which occurs in low-magnification WDS maps.

These maps can be displayed on an image analysis system in black and white or in color. In each of Figures F2-F4 are shown the individual black and white maps for each element and the composite color maps for each of the three pitted areas. The areas in Figures $F 2$ and $F 3$ were from the large specimen denoted $25-3 / 8 \mathrm{C} 2$, while the area in Figure $\mathrm{F} 4$ was from the small specimen labeled "out" and denoted 25-3/8c20 in our notation. The color maps were prepared by overlaying the iron, sulfur, and silicon ratio maps. Iron is red, sulfur is green, and silicon is blue. Silicon was not included in Figure F2 because there was so little observed in the silicon map of this area. There is also little silicon in the area of Figure F3. In both of these maps, sulfur and iron are the major components of the pitted region. In Figure $\mathrm{F} 4$ there is a lot of silicon in the pitted region and sulfur is located primarily along the interface between the iron metal and the siliconrich pit. Since other elements were observed in the EDS spectra of this region, an EDS map was prepared of this pit in order to include more elements 

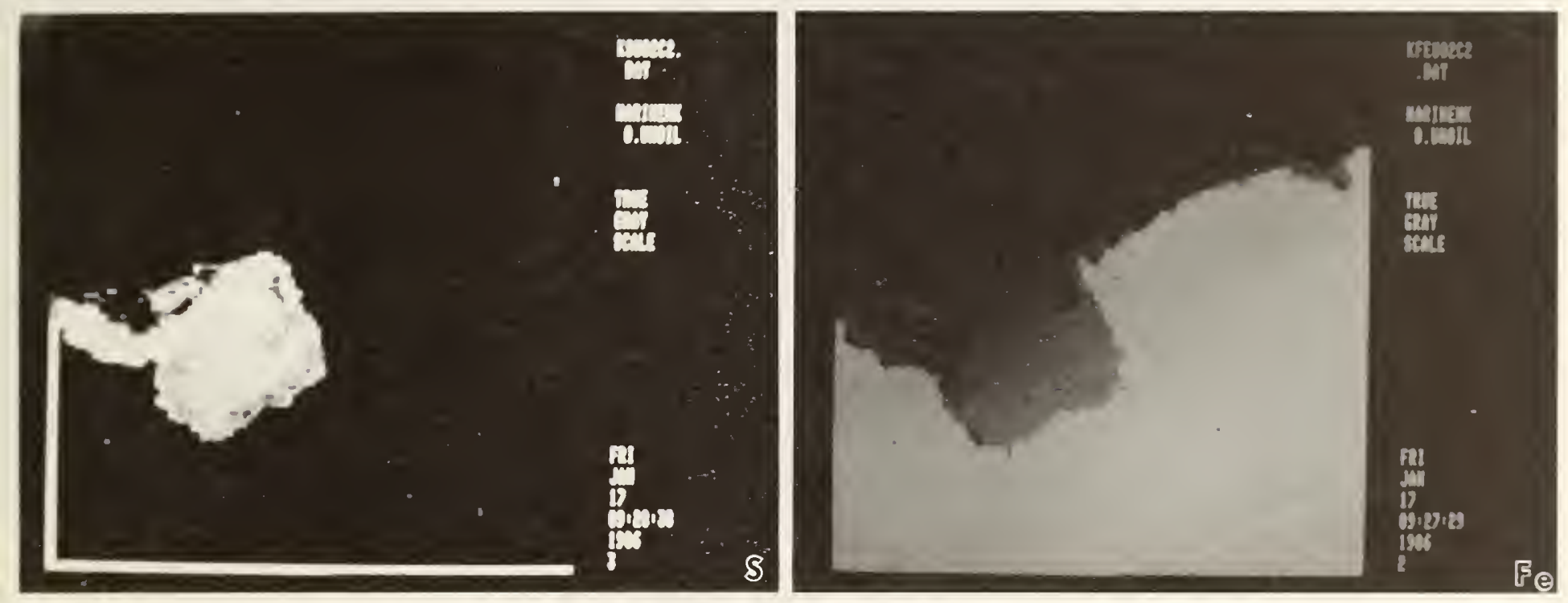
A. Sulfur
B. Iron

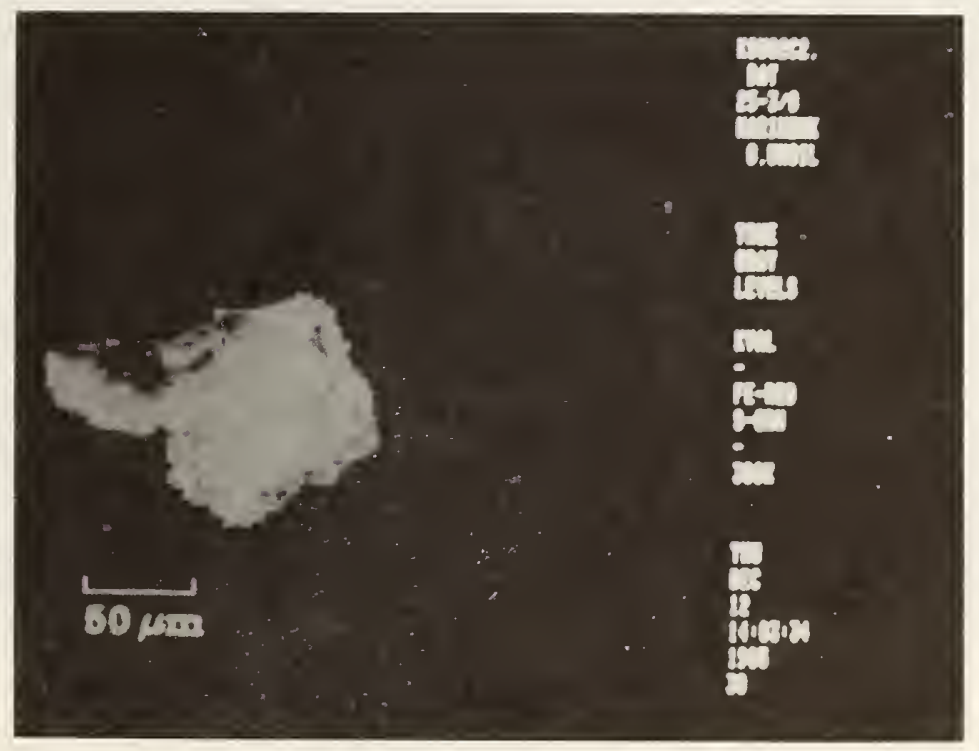

C. Composite color map

Figure F2. WDS maps of specimen 25-3/8C2. 

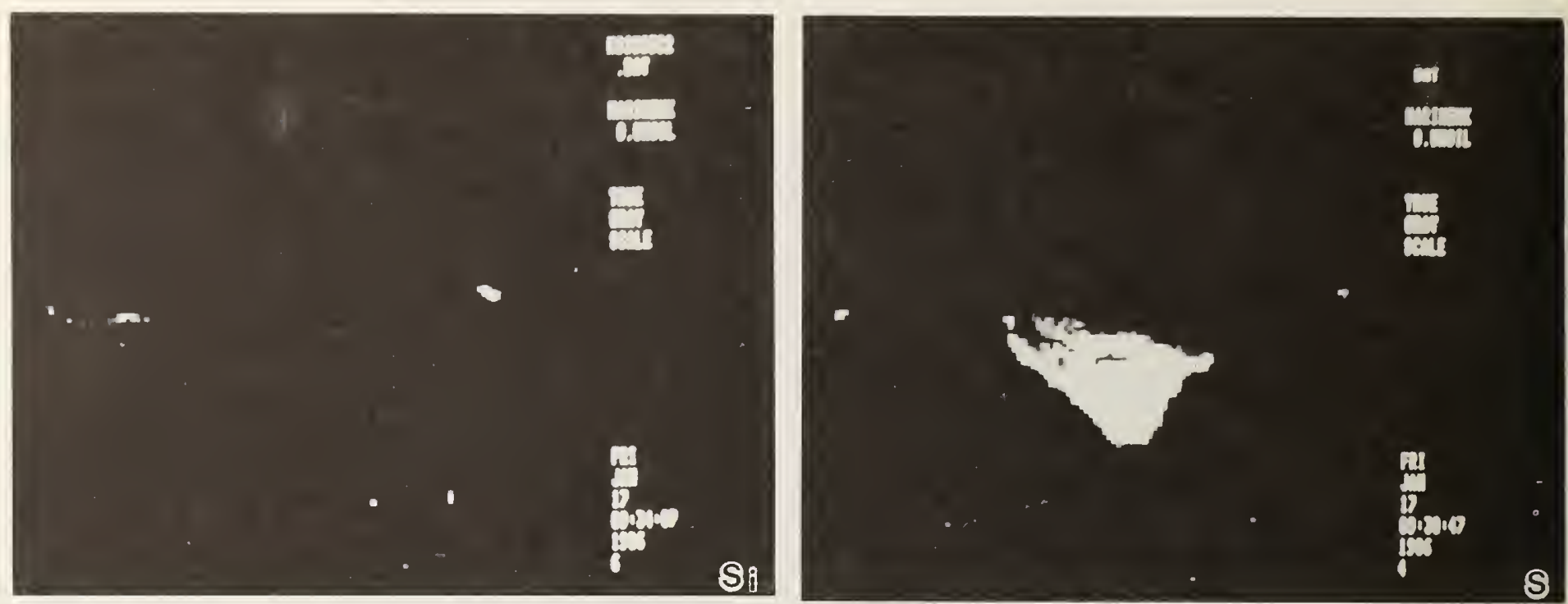

A. Silicon

B. Sulfur
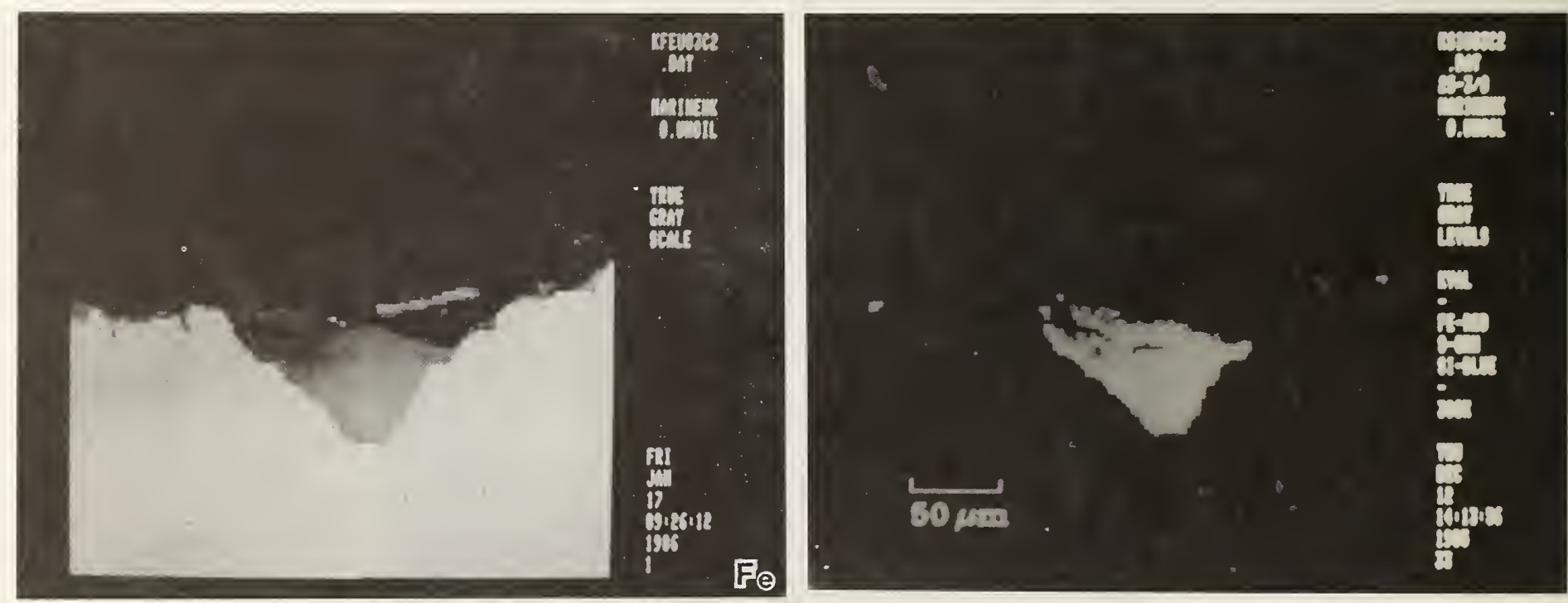

D. Composite color map

C. Iron

Figure F3. WDS maps of specimen 25-3/8C2. 


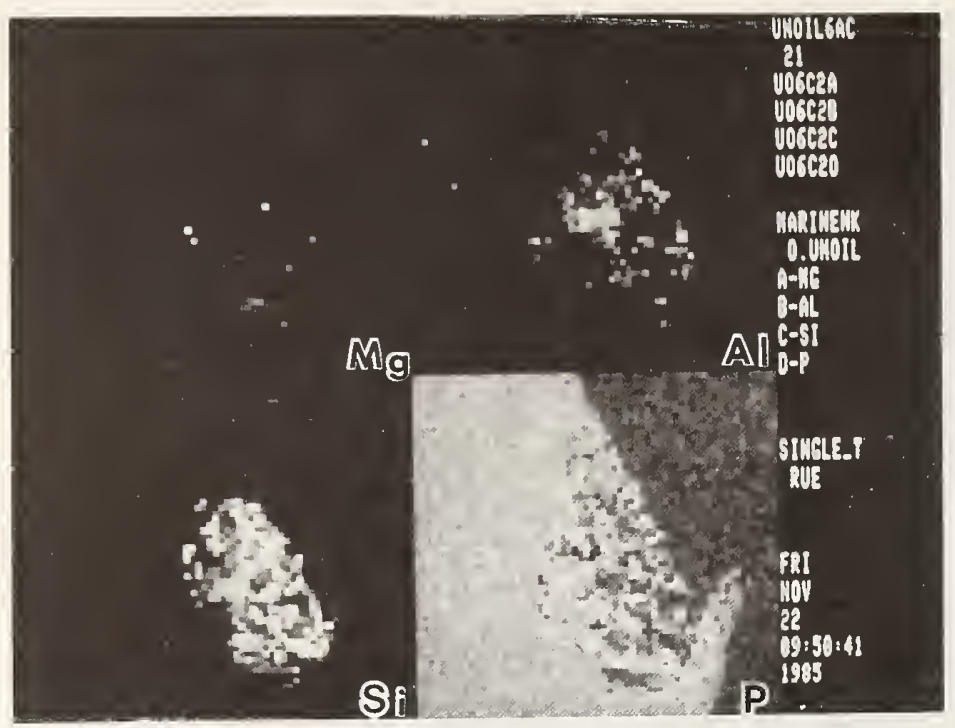

A. Magnesium, aluminum, silicon, phosphorus

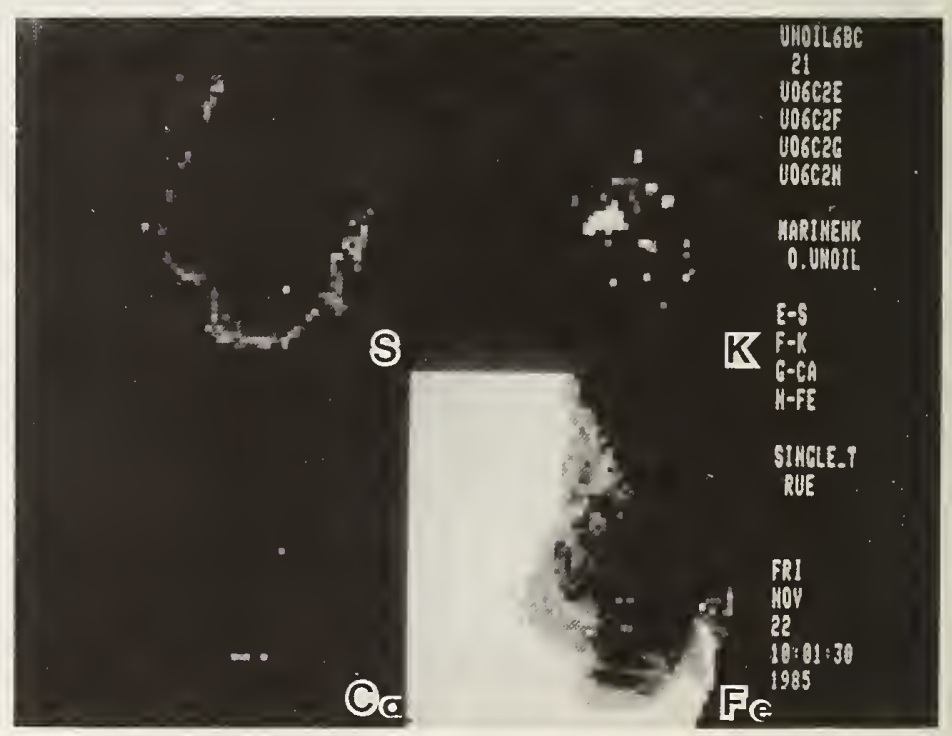

B. Sulfur, potassium, calcium, iron

Figure F5. Energy dispersive spectra of the pitted area of specimen 25-3/8C 20 . 
in a single-mapped region. (Only three elements can be observed at the same time with WDS since there are only three wavelength spectrometers on our instrument.) These EDS maps are displayed in black-and-white in Figure F5. Some elements such as aluminum, potassium, and phosphorus are present with silicon in the pitted region. Other elements found frequently in other EDS spectra of the fracture surface, calcium and magnesium, are not present to any noticeable extent in this region.

\section{ARCHIVAL STORAGE}

Laboratory notes on the analysis of these specimens are in the laboratory book labeled Service Analysis on pages 57-75. EDS spectra of the rough, corroded surface of the specimens are on FLEXTRAN floppy disk 1570A. The WDS digital maps of the cross sections and standards are on RT-11 floppy disks 106, 108, 109, and 110, and the EDS maps are on disks 111 and 112. The spectra for the EDS maps are on Flextran floppy disk 1572. These maps are stored on the VAX 780 computer in directory SYS\$IMAGE:[MARINENKO.UNOIL]. The names of the maps on the computer can be traced back to the original maps with the MAPS LOG (small green book). The maps used in this report are numbered 128-137. 
NBS-114A (REV. 2-8C)

U.S. DEPT. OF COMM.

BIBLIOGRAPHIC DATA

SHEET (See instructions)

1. PUBLICATION OR REPORT NO.

NBSTR $86-3049$

3. Publication Date

March 1986

4. TITLE AND SUBTITLE

Examination of a Pressure Vessel That Ruptured at the Chicago Refinery of the Union Oil Company on July 23, 1984

5. AUTHOR(S) Harry I. McHenry; T. Robert Shives; David T. Read; J. David McColskey; Charles H. Brady; Patrick T. Purtscher

6. PERFORMING ORGANIZATION (If joint or other than NBS. see instructions)

NATIONAL BUREAU OF STANDARDS

DEPARTMENT OF COMMERCE

WASHINGTON, D.C. 20234

9. SPONSORING ORGANIZATION NAME AND COMPLETE ADDRESS (Street, City, State, ZIP)

Occupational Safety and Health Administration

U.S. Department of Labor

Washington, DC 20210

10. SUPPLEMENTARY NOTES

Document describes a computer program; SF-185, FIPS Software Summary, is attached.

11. ABSTRACT (A 200-word or less factual summary of most significant information. If document includes a significant bibliography or literature survey. mention it here)

On July 23, 1984, a pressure vessel ruptured at the Chicago refinery of the Union Oil Company causing an explosion and fire that killed seventeen people and resulted in extensive property damage. The Occupational Safety and Health Administration (OSHA) requested NBS to conduct an investigation into the cause of the failure. The pressure vessel fractured along a path that was weakened by extensive cracking adjacent to a repair weld joining a replacement section to the vessel. These pre-existing cracks initiated in areas of a hard microstructure known to be susceptible to hydrogen stress cracking. This microstructure formed during the repair welding of the replacement section, and at the surface, it was not tempered by subsequent weld passes or thermal treatment. The cracks grew through the vessel wall due to hydrogen pressure cracking. When the depth of the largest of these pre-existing cracks exceeded 90 to $95 \%$ of the wall thickness, leakage occurred because the thin ligament of steel remaining in the cracked section ruptured. Because of the uniform depth of the pre-existing crack, the thin ligament continued to tear, causing the through crack to grow to a length of about $800 \mathrm{~mm}$. This crack triggered final fracture at the operating stress level of $35 \mathrm{MPa}$ because the toughness of the vessel steel was reduced by hydrogen embrittlement.

12. KEY WORDS (Six to twelve entries; alphabetical order; capitalize only proper names; and separate key words by semicolons) corrosion; failure analysis, fracture mechanics; hydrogen embrittlement; hydrogen induced cracking; hydrogen sulfide; magnetic particle inspection; mechanical properties; pressure vessel; steel; ultrasonic inspection 13. AVAILABILITY

X Unlimited

For Official Distribution. Do Not Release to NTIS

$\square$ Order From Superintendent of Documents, U.S. Government Printing Office, Washington, D.C. 20402.

14. NO. OF PRINTED PAGES

218

X Order From National Technical Information Service (NTIS), Springfield, VA. 2216I 

